\title{
Catalyzed Nano-Framework Stabilized High Density Reversible Hydrogen Storage Systems
}

Final Report

Xia Tang, Susanne M. Opalka, Daniel A. Mosher, Bruce L. Laube, Ronald J. Brown, Thomas H.

Vanderspurt, Sarah Arsenault

United Technologies Research Center

Robert Wu, Jamie Strickler

Albemarle Corporation

Ewa. Rönnebro*, Tim. Boyle and Joseph Cordaro

Sandia National Laboratories

* Currently at Pacific Northwest National Laboratories

June 30, 2010

Prepared for

Department of Energy

Office of Energy Efficiency and Renewable Energy

Hydrogen Program, Hydrogen Storage

Under Contract DE-FC36-07G017030

Sunita Satyapal / Ned Stetson, DOE Hydrogen Program Team Leader

Ned Stetson, DOE Headquarters Technology Manager

Paul Bakke, DOE Field Project Officer 


\section{Table of Contents}

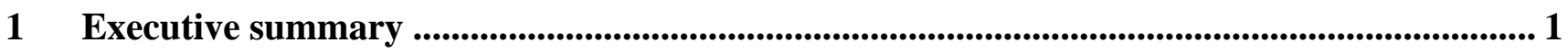

2 Introduction................................................................................................................................. 2

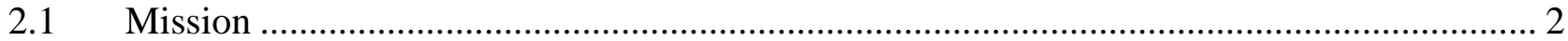

$2.2 \quad$ Scope

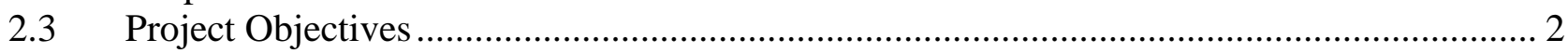

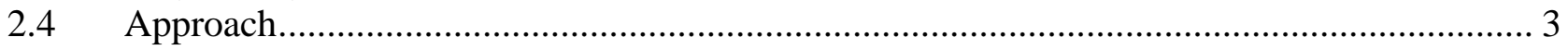

3 First Principles and Thermodynamic Modeling ........................................................................... 5

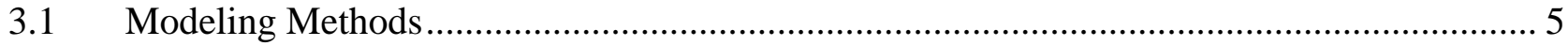

3.2 Survey of Oxide-Framework Interfacial Interactions ........................................................ 8

3.3 Calcium Borohydride Interactions with tetragonal $\mathrm{ZrO}_{2}$ Nano-framework .......................... 11

3.4 Calcium Borohydride Interactions with Pt-loaded $\mathrm{ZrO}_{2}$ Nano-framework .......................... 14

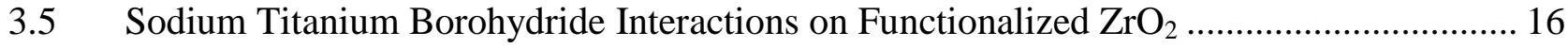

3.6 Thermodynamic Assessment of Framework Reactivity with Hydrides ............................... 21

4 Experimental Synthesis and Characterization of Nano-Framework ........................................ 23

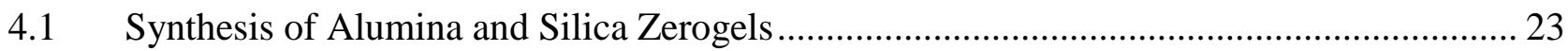

4.2 Zirconia Aerogel Synthesis and Calcination .................................................................. 23

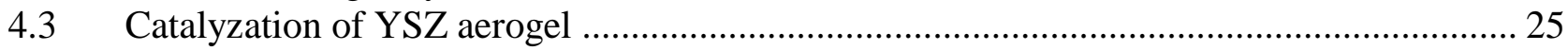

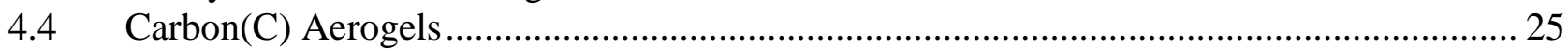

5 Screening of Nano-Framework Reactivity with Borohydrides ................................................... 27

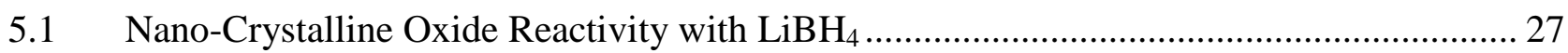

5.2 Selection of Oxide for Nano-framework Development....................................................... 29

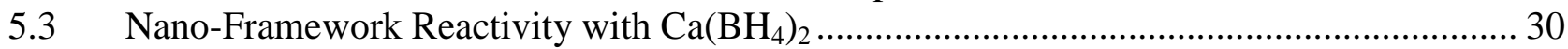

5.4 $\mathrm{H}_{2}$ Desorption and Absorption of $\mathrm{Ca}\left(\mathrm{BH}_{4}\right)_{2}$ SPEX Milled with Carbon Aerogels ............... 41

5.5 Hydrogen Desorption and Absorption of $\mathrm{Ca}\left(\mathrm{BH}_{4}\right)_{2}$ SPEX Milled with Uncatalyzed and Pt-

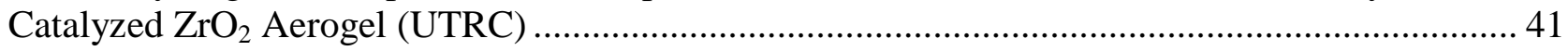

6 Hydride Formation in Nano-Framework Matrix .............................................................................. 45

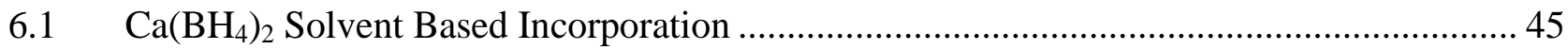

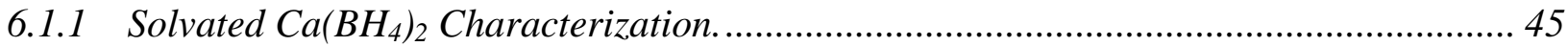

6.1.2 Aerogel Coatings ................................................................................................. 46

6.1.3 Incipient Wetness Incorporation in C aerogel................................................................. 49

6.1.4 Incorporation of $\mathrm{Ca}\left(\mathrm{BH}_{4}\right)_{2}$ in Pt-Catalyzed $\mathrm{ZrO}_{2}$ Aerogel............................................ 50

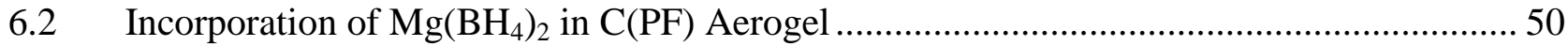

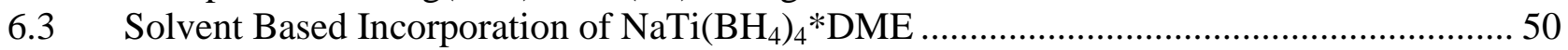

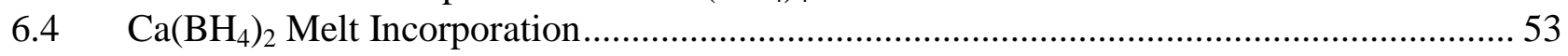

$7 \quad$ Hydride - Framework Composite Testing..................................................................................56

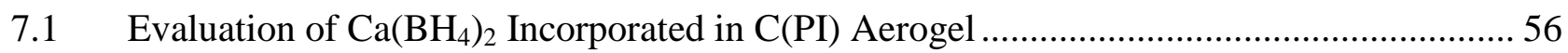

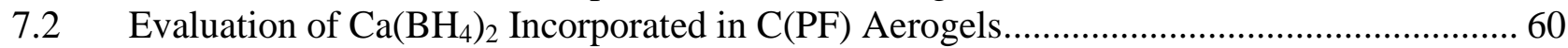

7.3 Evaluation $\mathrm{Ca}\left(\mathrm{BH}_{4}\right)_{2}$ Incorporated in Pt-Catalyzed $\mathrm{ZrO}_{2}$ Aerogel........................................6. 62

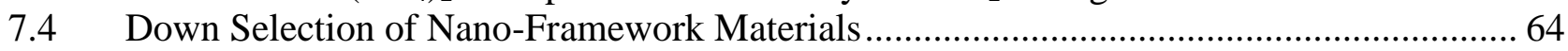

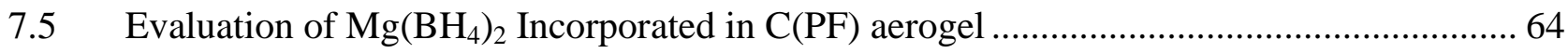

7.6 Stabilization of $\mathrm{NaTi}\left(\mathrm{BH}_{4}\right)_{4} * \mathrm{DME}$ by Nano-Framework Materials ..................................... 72 


\section{Table of Contents}

8 Carbon Aerogel - Hydride Nano-Framework Thermal Conductivity and Permeability Estimation................................................................................................................................................. 74

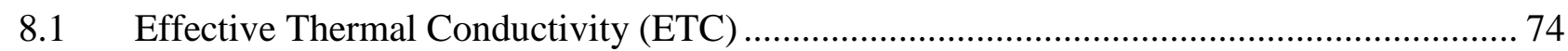

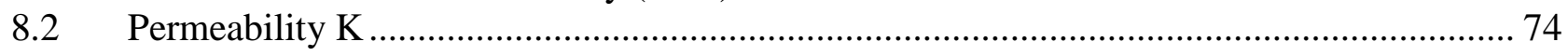

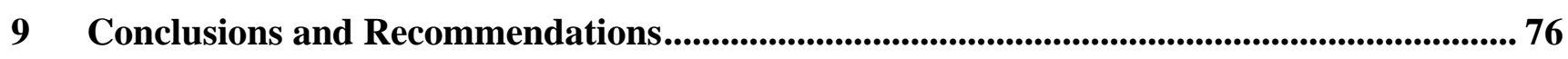

10 Publications and Presentations................................................................................................... 78

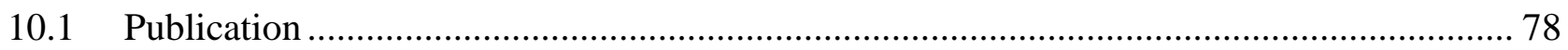

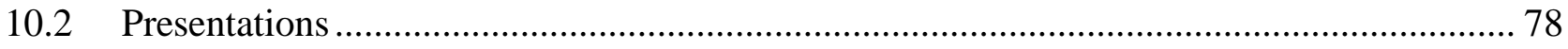

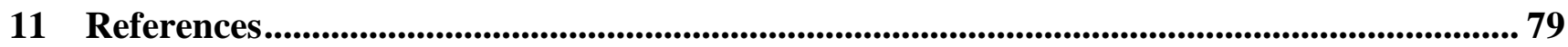

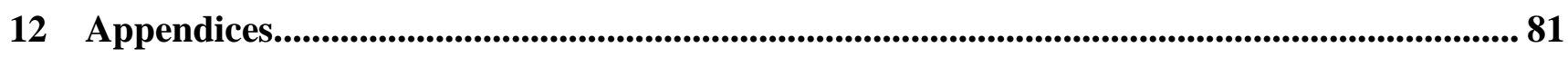




\section{List of Tables}

Table 1: Bulk and slab or cluster structural information for oxides and $\mathrm{LiBH}_{4}$ hydride.

Table 2: Comparison of predicted ground state electronic dehydrogenation enthalpies, $\Delta H_{\text {deh }}$, for neat $\mathrm{LiBH}_{4}$ and oxide-adsorbed $\mathrm{LiBH}_{4}$ with an experimentally measured value............................... 10

Table 3: Potential $\mathrm{Ca}\left(\mathrm{BH}_{4}\right)_{2}$ Dehydrogenation Reactions ................................................................ 12

Table 4: Most Favorable Adsorption Enthalpies, $\Delta H_{\text {ads }}$, of $\mathrm{Ca}\left(\mathrm{BH}_{4}\right)_{2}$-Derived Phases Adsorbed on undoped, doped and Pt-loaded $\mathrm{ZrO}_{2}$ (101) surfaces. Adsorption enthalpies were references to the constituent element standard states. 13

Table 5: Predicted dehydrogenation enthalpies for neat $\mathrm{Ca}\left(\mathrm{BH}_{4}\right)_{2}$ in bulk and cluster form, and for $\mathrm{Ca}\left(\mathrm{BH}_{4}\right)_{2} 5$ formula unit cluster adsorbed on $\mathrm{ZrO}_{2}$ and $\mathrm{Zr}_{30} \mathrm{Y}_{6} \mathrm{O}_{69}$, with the least endothermic dehydrogenation reaction forming the products indicated.

Table 6: Adsorption enthalpies, $\Delta H_{\text {ads }}$, for complexation of functionalizing agents with the hydride, $\mathrm{ZrO}_{2}$, and their interface.

Table 7: Dehydrogenation enthalpies, $\Delta H_{\text {deh }}$, for functionalized $\mathrm{NaTi}\left(\mathrm{BH}_{4}\right)_{4}$ or $\mathrm{NaTi}\left(\mathrm{BH}_{4}\right)_{4}-\mathrm{ZrO}_{2}$ dehydrogenated to unadsorbed or adsorbed dehydrogenation products. The most favorable scenarios are shown in bold.

Table 8: Atomic charges determined by Bader method for bonding interactions of multi-functional surface agents

Table 9: Size scale properties of zirconia aerogel for various processing.......................................... 24

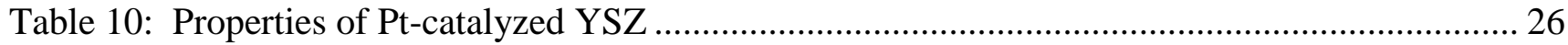

Table 11: Pore sizes, surface areas and elemental analysis of $\mathrm{C}$ aerogels ........................................... 26

Table 12: Weight variations for the select coated samples listed ....................................................... 48

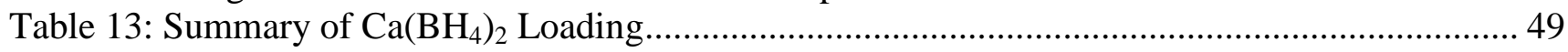

Table 14: Physical Properties of Silica Nano-Framework Materials ……………………………..... 50

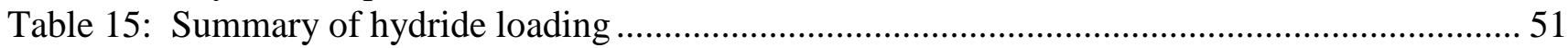

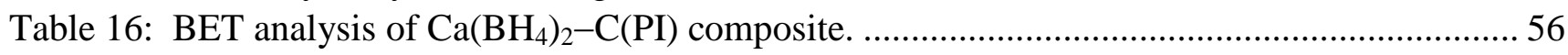

Table 17: Estimation of thermal conductivity and $\mathrm{H}_{2}$ permeability in $\mathrm{C}$ aerogel .............................. 75

Table 18: HSC equilibrium thermodynamic calculations of equations (7-9) ..................................... 81

Table 19: HSC equilibrium thermodynamic calculations of equations (10-13) .................................. 82 


\section{List of Figures}

Figure 1: Schematic of nano-framework filled with hydride in relation to $\mathrm{LiBH}_{4}$ cluster-on- $\mathrm{Al}_{2} \mathrm{O}_{3}$ slab input model configuration.

Figure 2: Simulated adsorption configurations for fully charged $\mathrm{LiBH}_{4}$ and discharged adsorbates on $\mathrm{Al}_{2} \mathrm{O}_{3}$ surface. In the atomic models, the $\mathrm{Al}$ atoms are gold, the $\mathrm{O}$ atoms are red, the $\mathrm{Li}$ atoms are blue, the $\mathrm{B}$ atoms are chartreuse, and the $\mathrm{H}$ atoms are white.

Figure 3: $\mathrm{Ca}\left(\mathrm{BH}_{4}\right)_{2} F d d 2(001)-\mathrm{ZrO}_{2} P 4_{2} / N M C Z$ (101) interface. The colors of the atoms are as follows: $\mathrm{Zr}$ - turquoise, $\mathrm{O}$ - red, Ca- royal blue, B- chartreuse, and $\mathrm{H}$-white.............................. 12

Figure 4: The Pt nano-raft configuration on $\mathrm{ZrO}_{2}$ (101) surface. The atoms are colored lime green for $\mathrm{Pt}$, aqua for $\mathrm{Zr}$, and red for $\mathrm{O}$.

Figure 5: Atomic models for the survey of ethylenediamine (EDA) chemical moiety interactions with

a) $\left[4 \mathrm{NaTi}\left(\mathrm{BH}_{4}\right)_{4}\right]$ cluster, b) $\mathrm{ZrO}_{2}(101)$ surface, and c) at the $\left[4 \mathrm{NaTi}\left(\mathrm{BH}_{4}\right)_{4}\right]$ cluster $-\mathrm{ZrO}_{2}(101)$

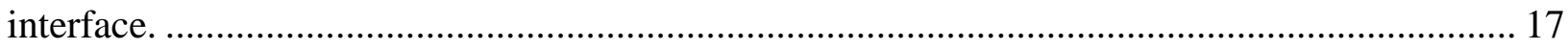

Figure 6: Yttria-stabilized zirconia calcined at $550{ }^{\circ} \mathrm{C}$ for 1 hour. .............................................. 24

Figure 7: XRD pattern of calcined $\left(550{ }^{\circ} \mathrm{C}\right.$ for 1 hour) zirconia aerogel sample............................ 24

Figure 8: TGA testing of un-calcined yttria-stabilized zirconia aerogel. ....................................... 25

Figure 9: Monolithic $\mathrm{C}$ aerogels prepared by carbonizing polymer.......................................... 26

Figure 10: Thermal gravimetric analysis-mass spectrometry of $\mathrm{LiBH}_{4}$ mixtures with $\mathrm{SiO}_{2}, \mathrm{Al}_{2} \mathrm{O}_{3}$ and

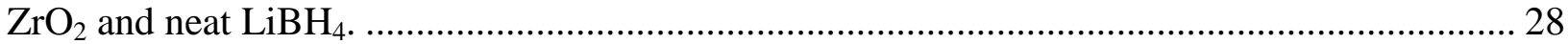

Figure 11: X-ray diffraction of the $\mathrm{LiBH}_{4}-\mathrm{SiO}_{2}$ mixtures, (a) as milled and (b) charged at $290{ }^{\circ} \mathrm{C}$ and

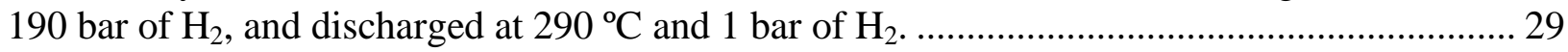

Figure 12: X-ray diffraction of the (a) $\mathrm{LiBH}_{4}-\mathrm{Al}_{2} \mathrm{O}_{3}$ and (b) $\mathrm{LiBH}_{4}-\mathrm{ZrO}_{2}$ mixtures after being

charged at $290{ }^{\circ} \mathrm{C}$ and 190 bar of $\mathrm{H}_{2}$, and discharged at $290{ }^{\circ} \mathrm{C}$ and 1 bar of $\mathrm{H}_{2} \ldots \ldots \ldots \ldots \ldots \ldots . . \ldots . \ldots . . .29$

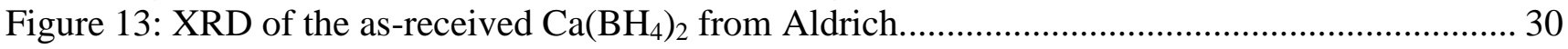

Figure 14: TGA-MS of as received $\mathrm{Ca}\left(\mathrm{BH}_{4}\right)_{2}$ from Aldrich. ................................................... 31

Figure 15: DSC of as received $\mathrm{Ca}\left(\mathrm{BH}_{4}\right)_{2}$ from Aldrich. ..................................................... 31

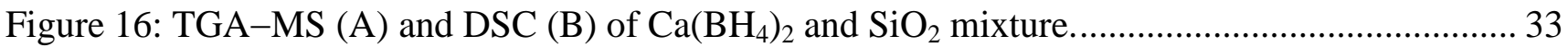

Figure 17: TGA-MS (A) and DSC (B) of $\mathrm{Ca}\left(\mathrm{BH}_{4}\right)_{2}$ and $\mathrm{Al}_{2} \mathrm{O}_{3}$ mixture................................... 34

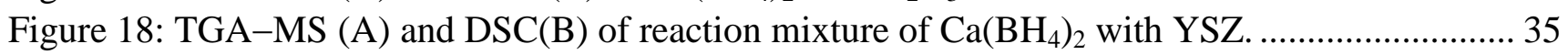

Figure 19: TGA-MS (A) and DSC(B) of $\mathrm{Ca}\left(\mathrm{BH}_{4}\right)_{2}$, SPEX milled for 30 min................................ 36

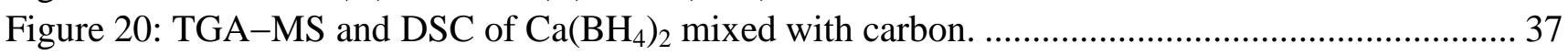

Figure 21: XRD of SPEX milled $\mathrm{Ca}\left(\mathrm{BH}_{4}\right)_{2}$ at various stages of cycling ...................................... 38

Figure 22: XRD of $\mathrm{Ca}\left(\mathrm{BH}_{4}\right)_{2}$ SPEX milled with YSZ ............................................................ 39

Figure 23: XRD spectra of $\mathrm{Ca}\left(\mathrm{BH}_{4}\right)_{2}$ SPEX milled with carbon aerogel.................................... 40

Figure 24: $\mathrm{XRD}$ of $\mathrm{Ca}\left(\mathrm{BH}_{4}\right)_{2}-\mathrm{C}(\mathrm{PF})$ mixtures after discharge at $350{ }^{\circ} \mathrm{C} / 1$ bar and recharge at 350

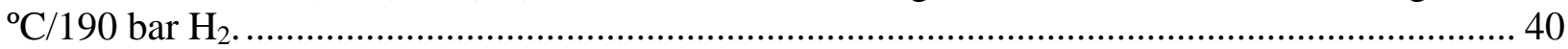

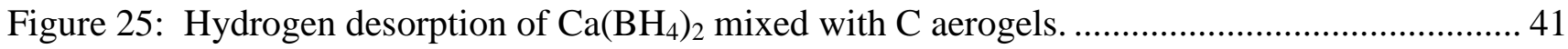

Figure 26: $\mathrm{H}_{2}$ desorption of $\mathrm{Ca}\left(\mathrm{BH}_{4}\right)_{2}$ SPEX milled with uncatalyzed and Pt-catalyzed YSZ .......... 42

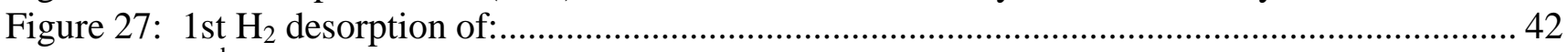

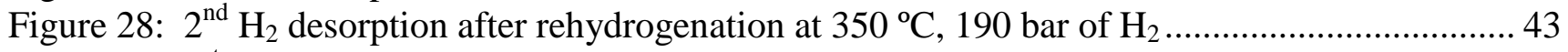

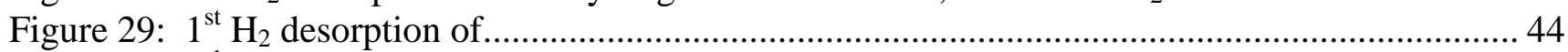

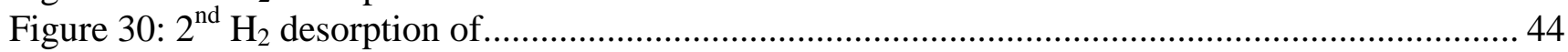

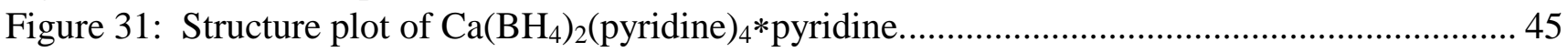

Figure 32: TGA/DTA of ground C-aerogel with $\mathrm{Ca}\left(\mathrm{BH}_{4}\right)_{2} *(\text { solvent })_{\mathrm{x}}$ : where the solvents were $(\mathrm{A})$

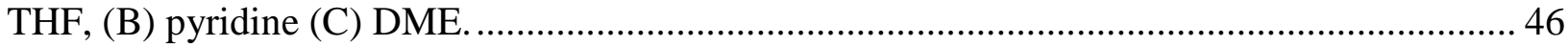




\section{List of Figures}

Figure 33: Beryllium dome X-ray diffraction pattern collected for (a) starting material and (b) starting material on $\mathrm{C}$-aerogel for $\mathrm{Ca}\left(\mathrm{BH}_{4}\right)_{2} *(\text { solvent })_{\mathrm{x}}$ : where the solvents were $(\mathrm{A}) \mathrm{THF}$, (B) pyridine, and (C) DME.

Figure 34: TGA/DTA of ground $\mathrm{C}$-aerogel with $\mathrm{Ca}\left(\mathrm{BH}_{4}\right)_{2} *(\text { solvent })_{\mathrm{x}}$ : where the solvents were $(\mathrm{A})$ THF, (B) pyridine (C) DME.

Figure 35: Beryllium dome X-ray diffraction of (a) $\mathrm{Ca}\left(\mathrm{BH}_{4}\right)_{2} *(\text { solvent })_{\mathrm{x}}$ neat and (b) coated on Caerogel, and (c) $\mathrm{C}$-aerogel, for the solvents (A) THF and (B) pyridine.

Figure 36: TGA/DTA of $\mathrm{C}$-aerogel coated with $\mathrm{Ca}\left(\mathrm{BH}_{4}\right)_{2} *(\text { solvent })_{\mathrm{x}}$ : where the solvents were $(\mathrm{A})$

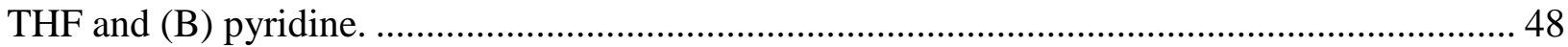

Figure 37: DSC of Ti-1 supported on Ineos ES-70, high loading. ............................................ 52

Figure 38: DSC of Ti-1 supported on Ineos ES-70, low loading. ................................................ 52

Figure 39: TGA of Ti-1 supported on Ineos ES-70, high loading.............................................. 53

Figure 40: Overlay DRIFTS of $\mathrm{NaTi}\left(\mathrm{BH}_{4}\right)_{4}$ complexes supported on Ineos silica.......................... 53

Figure 41: A plot from STMBMS comparing $\mathrm{H}_{2}$ evolution of $\mathrm{Ca}\left(\mathrm{BH}_{4}\right)_{2}-\mathrm{C}$-aerogel (red) with

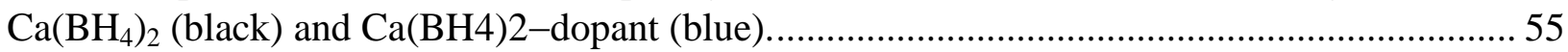

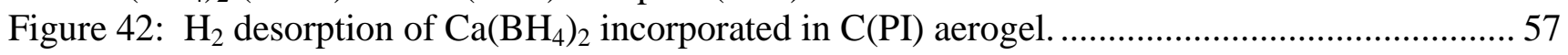

Figure 43: Hydrogen desorption of $\mathrm{Ca}\left(\mathrm{BH}_{4}\right)_{2}$ incorporated in $\mathrm{C}(\mathrm{PI})$ aerogels............................. 58

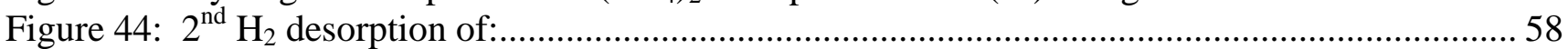

Figure 45: Cross - section morphology of $\mathrm{Ca}\left(\mathrm{BH}_{4}\right)_{2}$ incorporated in $\mathrm{C}(\mathrm{PI})$ aerogel........................ 59

Figure 46: Pore size distribution on desorption cycle in $\mathrm{N}_{2}$ BET measurement. ........................... 59

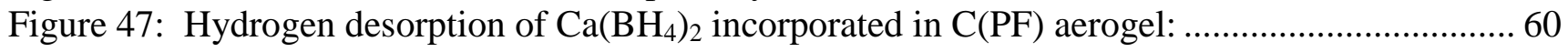

Figure 48: Solid State NMR of a) $\mathrm{Ca}\left(\mathrm{BH}_{4}\right)_{2}$ incorporated in $\mathrm{C}$-aerogel; ..................................... 61

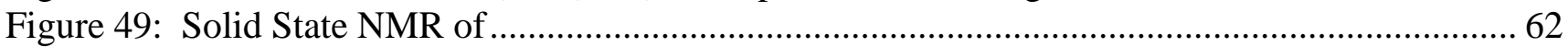

Figure 50: $1^{\text {st }}$ cycle $\mathrm{H}_{2}$ desorption of (A) SPEX milled $\mathrm{Ca}\left(\mathrm{BH}_{4}\right)_{2}$, (B) $\mathrm{Ca}\left(\mathrm{BH}_{4}\right)_{2}$ incorporated in

$\mathrm{Pt} / \mathrm{YSZ}$ aerogel and $(\mathrm{C}) \mathrm{Ca}\left(\mathrm{BH}_{4}\right)_{2}$ SPEX milled with $\mathrm{Pt} / \mathrm{YSZ}$ aerogel. ................................... 63

Figure 51: $2^{\text {nd }} \mathrm{H}$ desorption of $(\mathrm{A}) \mathrm{SPEX}$ milled $\mathrm{Ca}\left(\mathrm{BH}_{4}\right)_{2}$, (B) $\mathrm{Ca}\left(\mathrm{BH}_{4}\right)_{2}$ incorporated in $\mathrm{Pt} / \mathrm{YSZ}$ aerogel and $(\mathrm{C}) \mathrm{Ca}\left(\mathrm{BH}_{4}\right)_{2}$ SPEX milled with Pt/YSZ aerogel after absorption at $350{ }^{\circ} \mathrm{C} 190$ bar

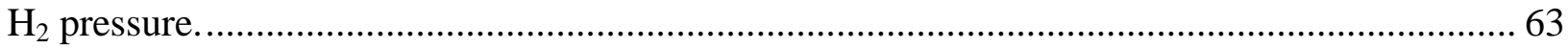

Figure 52: Comparison of $\mathrm{H}_{2}$ desorption properties of $\mathrm{Ca}\left(\mathrm{BH}_{4}\right)_{2}$ incorporated in $\mathrm{C}$ and $\mathrm{Pt} / \mathrm{YSZ}$

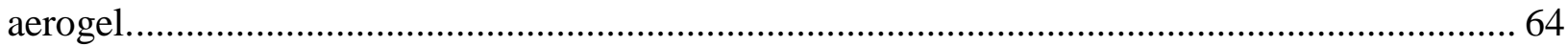

Figure 53: TGA-MS of $\mathrm{Mg}\left(\mathrm{BH}_{4}\right)_{2}$ etherate incorporated in $\mathrm{C}$ aerogel. ....................................... 65

Figure 54: TGA-MS of $\mathrm{Mg}\left(\mathrm{BH}_{4}\right)_{2}$ in $\mathrm{C}$ aerogel after desolvation in vacuum at $140{ }^{\circ} \mathrm{C}$ for 24 hours. 65

Figure 55: TGA-MS of $\mathrm{Mg}\left(\mathrm{BH}_{4}\right)_{2}$ in $\mathrm{C}$ aerogel after desolvation at $140{ }^{\circ} \mathrm{C}$ for 48 hours and $200{ }^{\circ} \mathrm{C}$

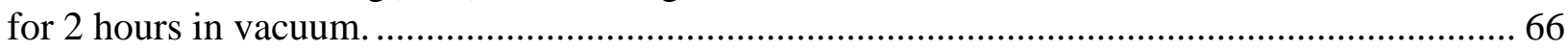

Figure 56: TGA-MS of (A) as synthesized bulk $\mathrm{Mg}\left(\mathrm{BH}_{4}\right)_{2}$ and (B) SPEX milled mixture of

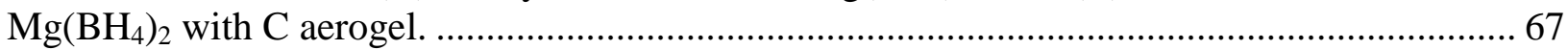

Figure 57: $\mathrm{H}_{2}$ desorption of (A) $\mathrm{Mg}\left(\mathrm{BH}_{4}\right)_{2}$ incorporated in $\mathrm{C}$ and (B) $\mathrm{Mg}\left(\mathrm{BH}_{4}\right)_{2}$ SPEX milled with C

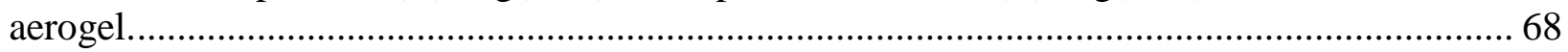

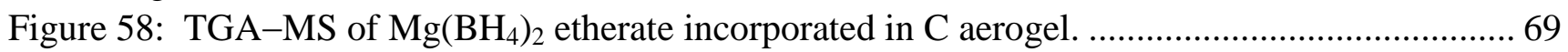

Figure 59: TGA-MS of $\mathrm{Mg}\left(\mathrm{BH}_{4}\right)_{2}$ in $\mathrm{C}$ aerogel after desolvation in vacuum at $140{ }^{\circ} \mathrm{C}$ for 24 hours

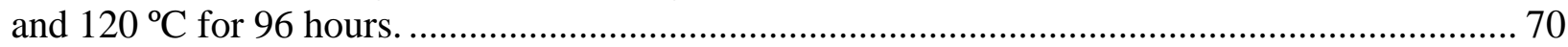

Figure 60: $\mathrm{H}_{2}$ desorption of $\mathrm{Mg}\left(\mathrm{BH}_{4}\right)_{2}$ incorporated in $\mathrm{C}(\mathrm{Red})$ and $\mathrm{Mg}\left(\mathrm{BH}_{4}\right)_{2}$ SPEX milled with C

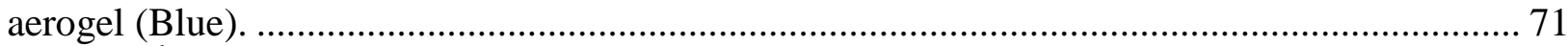

Figure 61: $2^{\text {nd }}$ cycle $\mathrm{H}_{2}$ desorption of $\mathrm{Mg}\left(\mathrm{BH}_{4}\right)_{2}$ incorporated in $\mathrm{C}$ and $\mathrm{Mg}\left(\mathrm{BH}_{4}\right)_{2}$ SPEX milled with $\mathrm{C}$ aerogel after rehydrogenation at $285^{\circ} \mathrm{C}$ and 190 bar of $\mathrm{H}_{2}$ pressure............................... 71

Figure 62: DRIFTS spectra of $\mathrm{NaTi}\left(\mathrm{BH}_{4}\right)_{4} \bullet 3 \mathrm{DME}$ and $\mathrm{NaTi}\left(\mathrm{BH}_{4}\right)_{4} \bullet \mathrm{DME}$ supported on silica. ....... 73 


\section{Acknowledgements}

The authors would like to thank Sunita Satyapal, Ned Stetson, Paul Bakke and the Department of Energy (DOE) for their support and input over the course of this project. Additional thanks go to the following organizations and individuals for their contributions, advice and guidance:

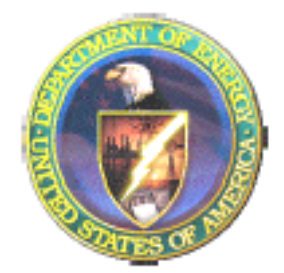

Sandia

National

Laboratories $\underline{\text { Sandia National Laboratories }}$

Vitalie Stavila

Aspen Aerogel

Wendell Rhine

aspen aerogels

Ohio State University

Ji-Cheng Zhao

University of Hawaii

Craig Jensen

United Technologies Research Center

Craig R. Walker, Laurence M. Pryor 


\section{Executive Summary}

\section{Executive summary}

A wide range of high capacity on-board rechargeable material candidates have exhibited non-ideal behavior related to irreversible hydrogen discharge / recharge behavior, and kinetic instability or retardation. This project addresses these issues by incorporating solvated and other forms of complex metal hydrides, with an emphasis on borohydrides, into nano-scale frameworks of low density, high surface area skeleton materials to stabilize, catalyze, and control desorption product formation associated with such complex metal hydrides. A variety of framework chemistries and hydride / framework combinations were investigated to make a relatively broad assessment of the method's potential.

In this project, the hydride / framework interactions were tuned to decrease desorption temperatures for highly stable compounds or increase desorption temperatures for unstable high capacity compounds, and to influence desorption product formation for improved reversibility. First principle modeling was used to explore heterogeneous catalysis of hydride reversibility by modeling $\mathrm{H}_{2}$ dissociation, hydrogen migration, and rehydrogenation. Atomic modeling also demonstrated enhanced $\mathrm{NaTi}\left(\mathrm{BH}_{4}\right)_{4}$ stabilization at nano-framework surfaces modified with multi-functional agents. Amine multi-functional agents were found to have more balanced interactions with nanoframework and hydride clusters than other functional groups investigated. Experimentation demonstrated that incorporation of $\mathrm{Ca}\left(\mathrm{BH}_{4}\right)_{2}$ and $\mathrm{Mg}\left(\mathrm{BH}_{4}\right)_{2}$ in aerogels enhanced hydride desorption kinetics. Carbon aerogels were identified as the most suitable nano-frameworks for hydride kinetic enhancement and high hydride loading. High loading of $\mathrm{NaTi}\left(\mathrm{BH}_{4}\right)_{4}$ *ligand complex in $\mathrm{SiO}_{2}$ aerogel was achieved and hydride stability was improved with the aerogel. Although improvements of desorption kinetics was observed, the incorporation of $\mathrm{Ca}\left(\mathrm{BH}_{4}\right)_{2}$ and $\mathrm{Mg}\left(\mathrm{BH}_{4}\right)_{2}$ in nano-frameworks did not improve their $\mathrm{H}_{2}$ absorption due to the formation of stable alkaline earth $\mathrm{B}_{12} \mathrm{H}_{12}$ intermediates upon rehydrogenation. This project primarily investigated the effect of nano-framework surface chemistry on hydride properties, while the effect of pore size is the focus area of other efforts (e.g., HRL, Sandia National Laboratories (SNL) etc.) within the Metal Hydride Center of Excellence $(\mathrm{MHCoE})$. The projects were complementary in gaining an overall understanding of the influence of nano-frameworks on hydride behavior. 


\section{Introduction}

\section{Introduction}

\subsection{Mission}

The project mission was to develop an advanced complex hydride storage medium with reversible, high volumetric and gravimetric hydrogen density to meet the DoE 2010 system requirements [1]. This project focused on some of the most promising hydrides with the potential to meet these requirements, primarily the complex metal borohydrides, which have theoretical hydrogen storage capacities $\geq 12 \mathrm{wt} \%$. Borohydrides that contain $\mathrm{Li}, \mathrm{Na}$, or $\mathrm{K}$ alkali cations decompose at elevated temperatures and cannot be recharged with hydrogen at moderate hydrogen pressures and temperatures. Others, such as those containing $\mathrm{Ti}, \mathrm{Al}$, or $\mathrm{Sc}$ cations, decompose within minutes or days unless stabilized by a solvent molecule. To achieve hydrogen reversibility, there is a need for a novel approach that both stabilizes and catalyzes these metastable complex metal hydrides in the absence of solvents.

\subsection{Scope}

To meet this challenge, the United Technologies Research Center (UTRC), as part of the Metal Hydride Center of Excellence (MHCoE), teamed with Albemarle Corporation (Albemarle), Sandia National Laboratories (SNL), and Aspen Aerogels to investigate the concept of incorporating the complex metal borohydrides in nano-framework structures consisting of low density, high surface area, thin-walled skeleton networks of interconnected cells, where the networks were predominantly aerogels. The electronegative elements in the aerogel walls, such as oxygen in the case of metal oxides like $\mathrm{Al}_{2} \mathrm{O}_{3}, \mathrm{TiO}_{2}$ or nitrogen in a carbonized imidazole polymer, were evaluated for their ability to stabilize the complex hydrides, supplanting the need for stabilizing solvent molecules. The effect of functionalizing carbon (C) aerogel surfaces with nitrogen and oxygen on hydride kinetics and reversibility were investigated. Raft-like hydrogen activation catalyst sites were investigated for their ability to facilitate hydrogen diffusion and enable reversibility. The nano-engineered approach provides a path towards meeting the DOE hydrogen gravimetric capacity, volumetric capacity, and discharge / recharge flow rate targets in a manner amenable to commercialization and reasonable cost.

\subsection{Project Objectives}

The high level goal of this project was to address the DOE Hydrogen Storage performance targets for improved material and system gravimetric density, volumetric density, and discharge rate of solid state, on-board reversible storage systems through the use of advanced nano-framework structures to stabilize and catalyze novel, high capacity hydrogen storage compounds. The approach also offered advantages to improve cyclic life, material densification, and heat transfer. The UTRC-led team included significant contributions by SNL, Albemarle, and Aspen Aerogels, and benefitted from interactions and collaborations with the MHCoE community.

This project involved three primary components. The hydride material or precursor was formed in a nano-framework structure by primarily liquid incorporation routes. As part of the MHCoE, this project focused on improving the performance of hydrogen storage material candidates developed within the center, primarily the complex metal borohydrides. A variety of nano-framework materials, including functionalized carbon and oxides, were developed and evaluated for their effect on hydride kinetics and reversibility. The hydride-framework interactions were designed to decrease desorption temperature for highly stable compounds, to stabilize and eliminate solvent ligands for unstable high 


\section{Introduction}

capacity compounds, and to influence desorption product formation for improved reversibility. Atomic modeling techniques were developed to simulate and design improved local surface interactions and heterogeneous catalysis by hydrogen activation catalysts. The experimental hydrogen storage media charged nano-framework was a semi-rigid system that maximized the packing density of the hydride and retained its pore structure when the hydrogen was removed. Hydrogen activation catalysts were loaded on the nano-framework walls to facilitate the discharge and recharge of the hydride.

\subsection{Approach}

This project combined atomic and thermodynamic modeling with experimental characterization and performance testing to progressively investigate the interactions and mechanistic behavior of advanced hydrogen storage nano-framework systems of increasing complexity, including nanoframework functionalization with hydrogen activation catalysts or surface-active ligands.

First principles and thermodynamic modeling was used at UTRC to pre-screen material interactions and to design balanced hydrogen storage media reactivity to guide the experimental development of self-assembled hydride-loaded catalyzed framework structures. In Phase I, atomic modeling was used to create and benchmark nano-framework slab models and screen hydride candidates, including $\mathrm{LiBH}_{4}$ (as a baseline hydride) and $\mathrm{Ca}\left(\mathrm{BH}_{4}\right)_{2}$, and their stabilization through physisorption or associative interactions and chemisorption interactions with the supports, mainly $\mathrm{ZrO}_{2}$. Doped $\mathrm{ZrO}_{2}$ with hydrogen activation catalyst rafts were also screened by atomic simulations. This was carried out by creating and benchmarking doped slab models; screening selected hydride reactions with doped supports; creating noble metal raft models; simulating $\mathrm{H}_{2}$ dissociation and spillover from raft surfaces; and simulating the promotion of selected complex formation / recharging. In Phase II, atomic modeling was used to evaluate nano-framework functionalization with O-bearing or N-bearing functional groups. The atomic modeling screened stabilization of the unstable sodium titanium tetraborohydride, $\mathrm{NaTi}\left(\mathrm{BH}_{4}\right)_{4}$, and its decomposition products, through associative interactions with amine or ether functional groups; evaluated stability of selected functional groups grafted on oxides; screened hydride reactions with grafted functional groups; and simulated the promotion of selected complex formation / recharging. Thermodynamic modeling was used to screen reactivity of hydrides and aerogels and identify thermodynamically stable aerogel materials.

Uncatalyzed and catalyzed frameworks with selected distributed catalysts were experimentally designed to enhance hydride stability and reversibility. New oxide nano-framework materials, including $\mathrm{SiO}_{2}, \mathrm{Al}_{2} \mathrm{O}_{3}$ and $\mathrm{ZrO}_{2}$, were synthesized using traditional sol-gel routes, such as the Teichner technique or other applicable techniques. Support structures, such as polymer or carbonized polymer aerogels, were prepared, in collaboration with Aspen Aerogels. Highly dispersed Group VIII metal rafts were deposited upon the surface of $\mathrm{ZrO}_{2}$ nano-framework through demonstrated UTRC metal loading techniques and other modified methods. Materials characterization was conducted at UTRC on nano-framework materials developed to evaluate the surface area, and the average pore size distribution of the nano-framework material prior to and after catalyst deposition.

Hydride development consisted of composition adjustment and preparation of novel hydrogen storage hydrides to improve nano-framework compatibility and reversibility performance. Solvated $\mathrm{NaTi}\left(\mathrm{BH}_{4}\right)_{4}$, developed under contract DE-FC36-04GO14012, was synthesized and refined, in collaboration with Albemarle. Solvated $\mathrm{Ca}\left(\mathrm{BH}_{4}\right)_{2}$ and $\mathrm{Mg}\left(\mathrm{BH}_{4}\right)_{2}$ were prepared at SNL and Ohio 


\section{Introduction}

State University through collaboration within the MHCoE, respectively, using established metathesis routes involving the reaction of a metal halide with an alkali metal borohydride in select solvents.

Complex metal hydrides were incorporated into catalyzed frameworks and were evaluated for loading characteristics, stabilization and reversibility performance. This task utilized techniques such as solvated or suspended infiltration, melt infiltration, and wicking at SNL, UTRC, and Albemarle to uniformly deposit the hydride material within the fine scale catalyzed frameworks. Incorporation of hydride through reaction under high-hydrogen pressures and temperatures directly into the nano framework were explored at SNL. Metal borohydrides were incorporated ex-situ into the framework using solution intercalation routes at SNL, UTRC, and Albemarle. Materials characterization was conducted on the hydride filled nano-frameworks to evaluate hydride chemical compositions and therefore the effectiveness of framework stabilization as well as deposition loading level and uniformity. Chemical characterization was accomplished through x-ray diffraction (XRD) measurements before and after hydride incorporation, where for amorphous materials, diffuse reflectance infrared Fourier transform spectroscopy (DRIFTS) analyses were conducted. Hydrogen storage material loading was evaluated using high resolution scanning electron microscopy (SEM) at UTRC. Thermal gravimetric analysis (TGA) and differential scanning calorimetry (DSC) were combined with mass spectrometry (MS) techniques at UTRC and SNL for solvent removal and initial reactivity screening after hydride incorporation.

Reaction testing was conducted in Phases I and II to evaluate the temperature dependence of desorption rates / capacities and the absorption rates / capacities at pressures up to 200 bars to screen the nano-framework / material systems for improved thermodynamics / kinetics and to assess reversibility. To help guide the development in Phase I, the effectiveness of nano-framework / catalyst / hydride combinations was experimentally screened using in-house Sievert's devices at UTRC and SNL to measure the desorption and absorption behavior for a limited scope of temperatures and pressures. More extensive reaction testing was performed in Phase II on the most promising material and framework candidates developed by UTRC / Albemarle and SNL for temperatures ranging from 80 to $300{ }^{\circ} \mathrm{C}$, pressures up to 200 bars and nominal durations from 8 to 24 hours to evaluate their kinetics and capacities. For the candidate material systems and key temperature / pressure conditions, cyclic studies were performed, to evaluate any evolution in the formation of overly stable products. Solid State nuclear magnetic resonance (NMR) was conducted to analyze amorphous desorption products at California Institute of Technology through collaborative effort with MHCoE.

Supplementing the desorption / absorption chemical measurements, preliminary measurements and modeling associated with heat and hydrogen gas transfer was conducted at UTRC to estimate the impact on the required system design, fabrication and performance. 


\section{First Principles and Thermodynamic Modeling}

\section{$3 \quad$ First Principles and Thermodynamic Modeling}

Atomic modeling was conducted to guide the selection and functionalization of nanoframeworks for confinement, stabilization, and enhancement of complex borohydride hydrogen storage reversibility. Atomic modeling simulations were first used to survey interfacial interactions of the most stable surfaces of oxide nano-framework candidates: $\mathrm{Al}_{2} \mathrm{O}_{3}, \mathrm{ZrO}_{2}$, and $\mathrm{SiO}_{2}$ with lithium borohydride, $\mathrm{LiBH}_{4}$. The weakest hydride adsorptive interactions were predicted to occur on the $\mathrm{ZrO}_{2}(101)$ surface, reducing the likelihood of irreversible chemical reactions that could lead to side product formation. The nearly equivalent adsorption of the $\mathrm{LiBH}_{4}$ fully hydrided state and dehydrogenation products on $\mathrm{ZrO}_{2}$ minimized further stabilization of this very stable hydride. Atomic simulations of the hydride candidate, calcium borohydride, $\mathrm{Ca}\left(\mathrm{BH}_{4}\right)$, interactions with the newly selected $\mathrm{ZrO}_{2}$ framework did not reveal new dehydrogenation reaction mechanisms, or other competing side reactions that could lead to the loss of $\mathrm{H}_{2}$ storage capacity. The calculations revealed the same order of relative favorability for the known $\mathrm{Ca}\left(\mathrm{BH}_{4}\right)_{2}$ dehydrogenation reactions. However, all of the dehydrogenation enthalpies were slightly increased by in the presence of the $\mathrm{ZrO}_{2}$ surface, rendering $\mathrm{Ca}\left(\mathrm{BH}_{4}\right)_{2}$ less thermodynamically reversible. Mechanistic investigations were then made to simulate the influence of Pt nano-rafts loaded on the $\mathrm{ZrO}_{2}(101)$ surface on the: a) adsorption interactions with $\mathrm{Ca}\left(\mathrm{BH}_{4}\right)_{2}$ and its dehydrogenation intermediates, b) $\mathrm{H}_{2}$ dissociation on $\mathrm{Pt}$ and $\mathrm{H}$ spillover onto $\mathrm{ZrO}_{2}$, and c) rehydrogenation of $\mathrm{Ca}\left(\mathrm{BH}_{4}\right)_{2}$ dehydrogenation products. The atomic modeling demonstrated the utility of $\mathrm{H}_{2}$ activation catalysts, such as $\mathrm{Pt}$, to facilitate formation, adsorption, and transfer of atomic $\mathrm{H}$, and to enhance binding and rehydrogenation of dehydrided phases. Finally, atomic simulations probed the concept of using chemically-modified inorganic nano-frameworks to stabilize unstable, high capacity hydrogen storage media, to replace the need for ligand-stabilization of high capacity hydrides. The predictions identified several amine functionalizing agents that slightly thermodynamically stabilized the unstable hydride, sodium titanium tetraborohydride, $\mathrm{NaTi}\left(\mathrm{BH}_{4}\right)_{4}$ in the presence of the $\mathrm{ZrO}_{2}$ surface. The best candidate, ethylenediamine (EDA) produced a balanced interaction at the $\mathrm{NaTi}\left(\mathrm{BH}_{4}\right)_{4}-\mathrm{ZrO}_{2}$ interface, dissociating to a functionalized surface upon $\mathrm{NaTi}\left(\mathrm{BH}_{4}\right)_{4}$ dehydrogenation. Thermodynamic modeling was performed to assess reactivity of oxide nano-framework with hydride. The calculation indicated that $\mathrm{SiO}_{2}, \mathrm{Al}_{2} \mathrm{O}_{3}$ and $\mathrm{ZrO}_{2}$ are susceptible to react with $\mathrm{LiBH}_{4}$, forming corresponding mixed oxides and borides. The prediction leads to experimental verification of these reactions in Section 5.

\subsection{Modeling Methods}

Atomic modeling was conducted in concert with thermodynamic modeling and experimentation to screen the interactions of a wide range of oxide framework bulk and surface chemistries with complex borohydrides, with the goal of designing robust oxide frameworks that enhance hydride reversibility and cyclability. The emphasis here was to atomistically probe local chemical interactions at the hydride-oxide framework interface which have the potential to influence hydride stability, dehydrogenation / rehydrogenation pathways, and dehydrogenation products, yet which may be very difficult to directly observe or discern experimentally. The modeling was relevant in providing insight to the experimental results on the influence of the interfacial structure and chemistry occurring at very small length-scales, i.e. the impact of ionic and electronic interactions at local points of contact between the hydride and nano-framework, on hydride thermodynamic de- / re-hydrogenation reversibility. These simulations did not investigate mesoscale framework features (e.g., hydride confinement within a nano-sized pore) that would be important for mass and thermal transfer phenomena that control hydride hydrogenation / dehydrogenation kinetics. 


\section{First Principles and Thermodynamic Modeling}

The oxide nano-framework-complex hydride interfaces were represented in this study as a hydride cluster on top of an oxide surface slab, bonded through their most stable surfaces. The cluster-on-slab configuration, shown schematically in Figure 1, avoided the inherent difficulties of simulating periodic interfaces with a slab-on-slab configuration due to the long periodic distances required for registration of the different crystal structures. The cluster-on-slab configuration also allowed more degrees of freedom for the hydride interfacial atoms to locally interact and bond with the oxide surface, since the interfacial bonding interactions in a slab-on-slab configuration would be restricted in the periodic interfacial plane and would be mainly accommodated normal to this plane. All atomic structures were modeled with the plane wave basis Vienna ab initio simulation package (VASP) density functional theory code with projector augmented wave (PAW) potentials and the PerdewWang 91 generalized gradient approximation for the exchange correlation functional [2-6]. Regular PAW potentials were used for all atoms, except the $\mathrm{Zr}$ _sv potential including the semi core states was used to represent Zr. Standard parameters utilized for all of the nonpolarized models included a plane wave expansion cutoff of $410 \mathrm{eV}$, a $0.3 / \AA$ or finer space k-point mesh, Gaussian smearing with an energy broadening of $0.2 \mathrm{eV}$, and an electronic self-consistent field convergence of $10^{-6} \mathrm{eV}$. The ground state structures were minimized with the conjugate gradient algorithm until the HellmannFeynman forces were all below $0.005 \mathrm{eV} / \AA$.

The oxide nano-framework-complex hydride interface models were developed progressively by minimizing the oxide and hydride bulk structures, then the oxide slabs and hydride clusters cleaved from the bulk structures, and finally the interfaces formed between the oxide slabs and hydride clusters. First, the atomic positions and lattice parameters of the bulk phase periodic structures were minimized, with the bulk phase dimensions validated to be well within $2 \%$ of the experimental measured values. Next, the bulk phases were cleaved along the lowest energy crystallographic planes and minimized to find the lowest energy, most stable surfaces. Oxide nano-frameworks are actually comprised of aggregated beads that are typically less than $200 \AA$ in diameter; where the beads are large enough for their centers to have bulk-like character. The nano-framework oxide bead low energy surfaces were represented with slab models formed with three stoichiometric oxide layers. The bottom stoichiometric layer of the oxide slab model was fixed to enforce bulk lattice dimensions, while the upper layers were allowed to relax with $12 \AA$ vacuum separation in the z-direction. The interacting surfaces of fully hydrided complex hydride nanocrystallite phases, which are typically tens of nanometers in diameter, were represented with hydride clusters cut out from the bulk hydride phase along the most stable surfaces positioning the low energy cleavage planes in between the hydride coordination complexes. The clusters were relaxed unconstrained in the same sized periodic cells as was used for the oxide slab models. 


\section{First Principles and Thermodynamic Modeling}

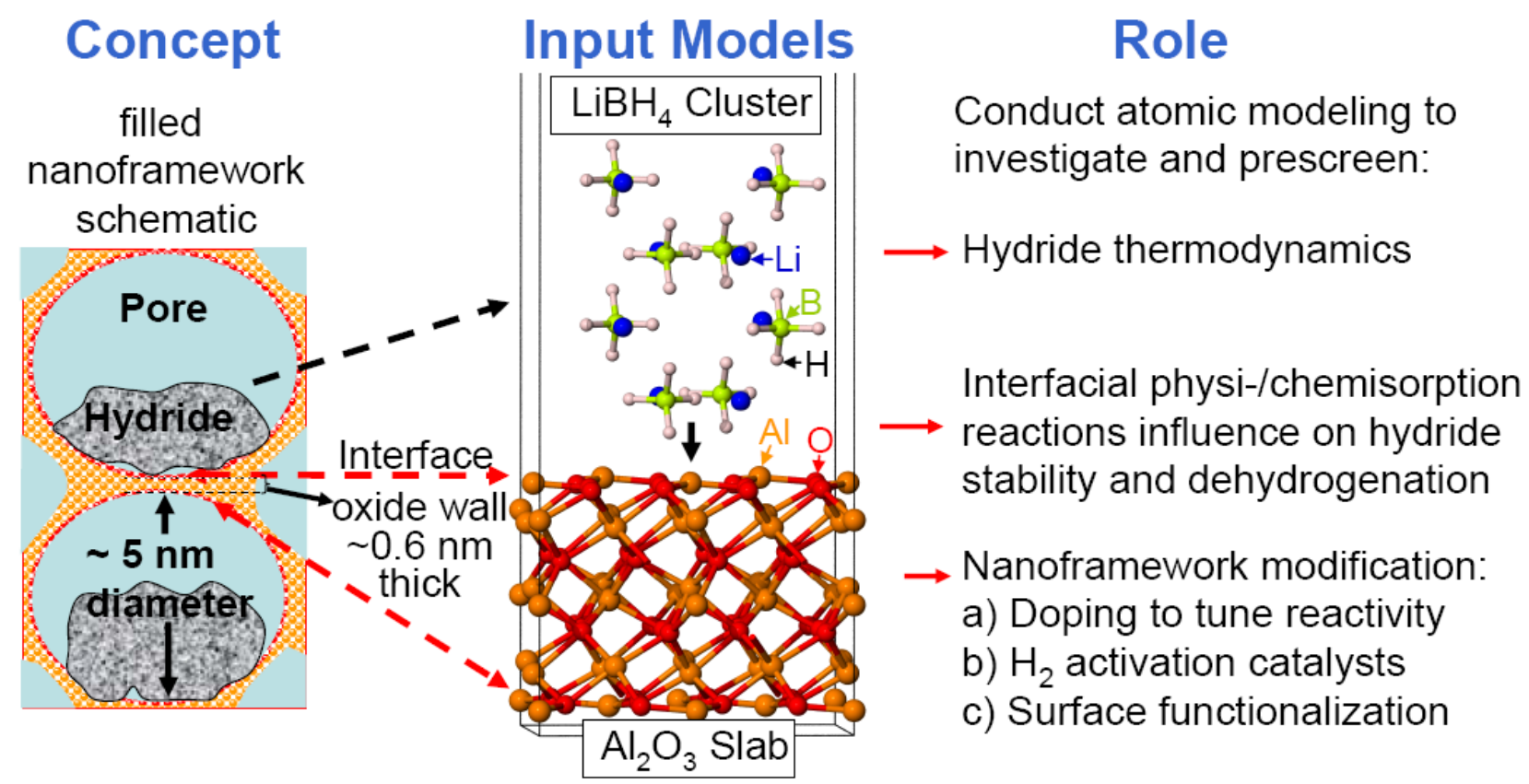

Figure 1: Schematic of nano-framework filled with hydride in relation to $\mathrm{LiBH}_{4}$ cluster-on- $\mathrm{Al}_{2} \mathrm{O}_{3}$ slab input model configuration.

Interfaces were then formed by positioning the hydride cluster lower surface above the oxide slab, expanding the cell in the $\mathrm{z}$ direction to ensure at least $12 \AA$ separation between interface periodic repeats. The coordinative unsaturation of the hydride cluster surfaces promoted hydride adsorption interactions with the oxide surface. The hydride cluster was recast and relaxed in the same periodic cell dimensions as each of the oxide-hydride interfaces. The ionic positions were relaxed to the ground state to arrive at the most stable configuration. The adsorption enthalpy, $\Delta H_{\text {ads }}$, was determined as the difference between the minimized interface enthalpy and the sum of the enthalpies of the oxide slab and hydride cluster minimized in the same size cell as the interface.

$\Delta H_{\text {ads }}=H_{\text {oxide-hydride interface }}-\left(H_{\text {oxide slab }}+H_{\text {hydride cluster }}\right)$

The adsorption interactions of the complex hydride dehydrogenation end-products were simulated to predict the influence of the oxide surfaces on dehydrogenation of the complex hydride cluster. An increasingly negative $\Delta H_{\text {ads }}$ value signified an increasing adsorption binding strength. The hydride dehydrogenation enthalpy, $\Delta H_{\text {deh }}$ was determined from sum of the enthalpies of the dehydrogenation products minus the enthalpy of the fully hydrided state.

$\Delta H_{\text {deh }}=\sum\left[H_{\text {dehydrogenation products including oxide surface }}\right]-H_{\text {oxide-hydride interface }}$

In the presence of the oxide framework, the hydride dehydrogenation reaction equation was modified to include the enthalpy of the most favorable dehydrogenation products adsorbed on the oxide surface. The enthalpy of the slab with the most favorable adsorption product was used in the $\Delta H_{\text {deh }}$ determination, stoichiometrically adjusting equation (2) to account for the adsorbed species. 


\section{First Principles and Thermodynamic Modeling}

\subsection{Survey of Oxide-Framework Interfacial Interactions}

Atomic modeling was conducted in concert with thermodynamic modeling and experimentation to guide the experimental down-selection of oxide frameworks to be developed for hydride confinement. The oxide slabs were formed from the most stable low temperature crystal phase structures for $\mathrm{ZrO}_{2}$ [7], $\mathrm{Al}_{2} \mathrm{O}_{3}$ [8] and $\mathrm{SiO}_{2}$ [9], detailed in Table 1. Here, $\mathrm{LiBH}_{4}$ was used as a baseline system because it is a well known hydride, especially for its interaction with $\mathrm{C}$-based nano-frameworks. The eight formula unit $(\mathrm{FU}) \mathrm{LiBH}_{4}(100) \times(010) \times(001)$ cluster was derived from the $\mathrm{LiBH}_{4}$ Pnma phase [10].

Table 1: Bulk and slab or cluster structural information for oxides and $\mathrm{LiBH}_{4}$ hydride.

\begin{tabular}{|c|c|c|c|c|c|c|}
\hline $\begin{array}{l}\text { Phase } \\
\text { Space } \\
\text { Group }\end{array}$ & $\begin{array}{c}\text { Crystal } \\
\text { Structure } \\
\text { Reference }\end{array}$ & $\begin{array}{l}\text { Form / } \\
\text { Layers }\end{array}$ & $\begin{array}{c}\text { Unit Cell } \\
\text { Transformation } \\
(\mathrm{x} \times \mathrm{y} \times \mathrm{z})\end{array}$ & $\begin{array}{c}\text { Total } \\
\text { Formula } \\
\text { Units }\end{array}$ & $\begin{array}{c}\text { Most } \\
\text { Stable } \\
\text { Surface }\end{array}$ & $\begin{array}{l}\text { Most Stable } \\
\text { Termination }\end{array}$ \\
\hline $\begin{array}{c}\mathrm{ZrO}_{2} \\
P 12_{1} / c_{1}\end{array}$ & $\begin{array}{c}\text { ICSD } \\
86692 \\
{[7]} \\
\end{array}$ & $\begin{array}{c}\text { Slab } \\
3 \text { layers }\end{array}$ & $2 \times 2 \times 2$ & 12 & (111) & $\begin{array}{c}\text { O top and } \\
\text { bottom }\end{array}$ \\
\hline $\begin{array}{c}\mathrm{Al}_{2} \mathrm{O}_{3} \\
R \overline{3} c\end{array}$ & $\begin{array}{c}\text { ICSD } \\
92628 \\
{[8]} \\
\end{array}$ & $\begin{array}{c}\text { Slab } \\
4 \text { layers }\end{array}$ & $(200) \times(120) \times(001)$ & 16 & $(001)$ & $\begin{array}{l}\text { O top and } \\
\text { bottom (after } \\
\text { relaxation) }\end{array}$ \\
\hline $\begin{array}{c}\mathrm{SiO}_{2} \\
P 3_{1} 21\end{array}$ & $\begin{array}{c}\text { ICSD } \\
79637 \\
{[9]} \\
\end{array}$ & $\begin{array}{c}\text { Slab } \\
4 \text { layers }\end{array}$ & $(200) \times(120) \times(001)$ & 16 & $(001)$ & $\begin{array}{l}\text { O top and } \\
\text { bottom }\end{array}$ \\
\hline $\begin{array}{l}\mathrm{LiBH}_{4} \\
\text { Pnma }\end{array}$ & $\begin{array}{c}\text { ICSD } \\
95207 \\
{[10]} \\
\end{array}$ & $\begin{array}{l}\text { Cluster } \\
2 \text { layers }\end{array}$ & $1 \times 2 \times 1$ & 8 & $(010)$ & $\begin{array}{c}\mathrm{H} \text {, cleaved } \\
\text { between } \mathrm{BH}_{4}\end{array}$ \\
\hline
\end{tabular}

The nanocrystalline complex metal hydride thermodynamic stability may be influenced by adsorptive interactions with high surface area oxide frameworks. Stronger adsorption interactions resulted in increased bonding between the surfaces and more negative adsorption enthalpies, $\Delta H_{\text {ads. }}$ The results showed the strongest $\mathrm{LiBH}_{4}$ adsorption on the $\mathrm{Al}_{2} \mathrm{O}_{3}$ surface with an $\Delta H_{\text {ads }}$ of $-260 \mathrm{~kJ} / \mathrm{mole}$ and on the $\mathrm{SiO}_{2}$ surface with an $\Delta H_{\text {ads }}$ of $-251.1 \mathrm{~kJ} / \mathrm{mole}$, and the weakest binding on the $\mathrm{ZrO}_{2}$ surface with an $\Delta H_{\text {ads }}$ of $-43.8 \mathrm{~kJ} / \mathrm{mole}$. Thus, the atomic modeling predicted stronger bonding interactions for the $\mathrm{SiO}_{2}$ and $\mathrm{Al}_{2} \mathrm{O}_{3}$ surfaces observed to be more experimentally reactive. It is important to note the strong interactions of the $\mathrm{LiBH}_{4}$ cluster surface $\mathrm{Li}$ and $\mathrm{H}$ atoms with the oxide surfaces, where up to 2 Li atoms and $4 \mathrm{H}$ atoms were available at the interface to directly participate in interfacial adsorption interactions. The $\mathrm{LiBH}_{4}-\mathrm{Al}_{2} \mathrm{O}_{3}$ hydride-oxide bonding interactions can be observed in the minimized interface model shown in Figure 2, where bonds are drawn to guide the viewer's eye. In the interface formed with $\mathrm{Al}_{2} \mathrm{O}_{3}$, the 2 interfacial $\mathrm{Li}$ atoms each formed a 2-2.5 $\AA$ bond to 3 surface $\mathrm{O}$ atoms over a hollow in the $\mathrm{Al}_{2} \mathrm{O}_{3}$ surface. Four of the lower $\mathrm{H}$ atoms in each of the 2 adjacent $\mathrm{BH}_{4}{ }^{-}$clusters interacted with a surface $\mathrm{Al}$ atom over a distance of 1.8-2.0 $\AA$. The adsorptive interactions were 


\section{First Principles and Thermodynamic Modeling}

much less significant in the interface with the $\mathrm{ZrO}_{2}$ slab, minimizing further stabilization of the very stable $\mathrm{LiBH}_{4}$ phase.

The adsorption behavior of the $\mathrm{LiBH}_{4}$ constituent element atoms was simulated with respect to their standard state bulk forms, to probe the possible interactions of the dehydrogenation products with the oxide surfaces. Lithium atoms adsorbed very strongly on the $\mathrm{Al}_{2} \mathrm{O}_{3}$ and $\mathrm{ZrO}_{2}$ surfaces in the absence of the hydride. Boron atomic adsorption was not found to be favorable on any surface sites. Coupled $\mathrm{Li}$ and $\mathrm{H}$ adsorption was favorable on the $\mathrm{Al}_{2} \mathrm{O}_{3}$ surface, to the extent that $\mathrm{LiH}$ molecules positioned on the surface dissociated during minimization to form adjacent adsorbed $\mathrm{Li}$ and $\mathrm{H}$ atoms. Thus, the most favorable dehydrogenated state on the $\mathrm{Al}_{2} \mathrm{O}_{3}$ surface was adsorption of $2 \mathrm{Li}$ and $2 \mathrm{H}$ atoms, in the configuration shown in Figure 2.

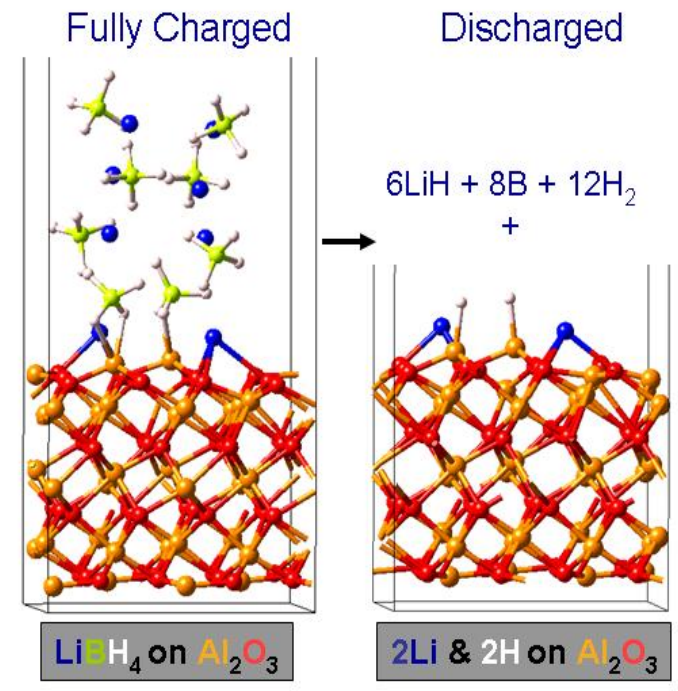

Figure 2: Simulated adsorption configurations for fully charged $\mathrm{LiBH}_{4}$ and discharged adsorbates on $\mathrm{Al}_{2} \mathrm{O}_{3}$ surface. In the atomic models, the $\mathrm{Al}$ atoms are gold, the $\mathrm{O}$ atoms are red, the $\mathrm{Li}$ atoms are blue, the $\mathrm{B}$ atoms are chartreuse, and the $\mathrm{H}$ atoms are white.

The $\Delta H_{\text {ads }}$ value for the $2 \mathrm{Li}$ and the $2 \mathrm{H}$ adsorption on the $\mathrm{Al}_{2} \mathrm{O}_{3}$ surface was $-393.6 \mathrm{~kJ} / \mathrm{mole}$. The most favorable adsorption product on the $\mathrm{ZrO}_{2}$ surface was a single $\mathrm{Li}$ atom, where adjacent adsorbed $\mathrm{Li}$ and $\mathrm{H}$ atoms were not favorable. The $\Delta H_{\text {ads }}$ value for Li adsorption on the $\mathrm{ZrO}_{2}$ surface was -140.3 $\mathrm{kJ} /$ mole. Such strong $\mathrm{Li}-\mathrm{O}$ interactions may precede the formation of mixed oxide phases, which could lead to loss in $\mathrm{H}$ storage capacity. It is envisioned the surface-adsorbed Li in the dehydrided state could play a role in orchestrating the nucleation of the $\mathrm{LiBH}_{4}$ rehydrogenation, ultimately coordinating to the surrounding hydride atoms in the fully hydrided state.

Nanocrystalline complex metal hydride systems, like $\mathrm{LiBH}_{4}$, dehydrogenate through a first order reaction [11] at the surface, simultaneously releasing $\mathrm{H}_{2}$ while forming multiple compound or elemental phases. Stable hydrides have positive $\Delta H_{\text {deh }}$ values, where hydride dehydrogenation / rehydrogenation reaction $\Delta H_{\text {deh }}$ approaching $\approx 40 \mathrm{~kJ} / \mathrm{mole}_{2}$ [12] are thermodynamically reversible within the typical operating window ranging from 25 to $120{ }^{\circ} \mathrm{C}$ in temperature and 1 to 100 bar in pressure. The balance between the adsorptive interactions of the fully hydrided state and of 


\section{First Principles and Thermodynamic Modeling}

dehydrogenation products with a framework surface may locally influence the $\Delta H_{\text {deh }}$, the reversibility of the dehydrogenation reaction. The predicted dehydrogenation reactions and the respective $\Delta H_{\text {deh }}$ for the $\mathrm{LiBH}_{4}$ cluster on both surfaces are given in Table 2, compared to those predicted for the $\mathrm{LiBH}_{4} 8$ FU $(100) \times(010) \times(001)$ cluster and the $\mathrm{LiBH}_{4}$ bulk phase.

Table 2: Comparison of predicted ground state electronic dehydrogenation enthalpies, $\Delta H_{\mathrm{deh}}$, for neat $\mathrm{LiBH}_{4}$ and oxide-adsorbed $\mathrm{LiBH}_{4}$ with an experimentally measured value.

\begin{tabular}{|c|c|c|c|}
\hline $\mathrm{LiBH}_{4}$ State & $\begin{array}{l}\text { Most Favorable } \\
\text { Dehydrogenation } \\
\text { Reaction Products }\end{array}$ & $\begin{array}{l}\text { Ground State Electronic } \\
\text { Dehydrogenation } \\
\text { Enthalpy } \\
\Delta H_{\text {deh }}\left(\mathrm{kJ} / \text { mole } \mathrm{LiBH}_{4}\right)\end{array}$ & $\begin{array}{l}\text { Ground State Electronic } \\
\text { Dehydrogenation } \\
\text { Enthalpy } \\
\Delta H_{\text {deh }}\left(\mathrm{kJ} / \text { mole }_{2}\right)\end{array}$ \\
\hline $\mathrm{LiBH}_{4}$ Pnma bulk & $n \mathrm{LiH}+n \mathrm{~B}+1.5 n \mathrm{H}_{2}$ & 127.0 & 84.6 \\
\hline $\begin{array}{c}\mathrm{LiBH}_{4} 8 \mathrm{FU}^{\mathrm{a}} \\
\quad \text { cluster- } \\
(100) \times(010) \times(001) \\
\end{array}$ & $8 \mathrm{LiH}+8 \mathrm{~B}+12 \mathrm{H}_{2}$ & 100.6 & 67.1 \\
\hline $\begin{array}{l}\mathrm{LiBH}_{4} 8 \mathrm{FU} \\
\text { cluster- } \\
\mathrm{Al}_{2} \mathrm{O}_{3} \text { slab } \\
\text { interface }\end{array}$ & $\begin{array}{c}2 \mathrm{Li}+2 \mathrm{H} \text { adsorbed on } \\
\mathrm{Al}_{2} \mathrm{O}_{3} \text { slab }+6 \mathrm{LiH}+8 \mathrm{~B} \\
+12 \mathrm{H}_{2}\end{array}$ & 107.8 & 71.8 \\
\hline $\begin{array}{c}\mathrm{LiBH}_{4} 8 \mathrm{FU} \\
\quad \begin{array}{c}\text { cluster- } \\
\mathrm{ZrO}_{2} \text { slab interface }\end{array} \\
\end{array}$ & $\begin{array}{c}1 \mathrm{Li} \text { adsorbed on } \mathrm{ZrO}_{2} \\
\mathrm{slab}+7 \mathrm{LiH}+8 \mathrm{~B}+ \\
12.5 \mathrm{H}_{2} \\
\end{array}$ & 112.4 & 74.9 \\
\hline $\begin{array}{c}\mathrm{LiBH}_{4} \\
\text { experimental } \\
(298 \mathrm{~K}, 1 \text { bar }) \\
\end{array}$ & $n \mathrm{LiH}+n \mathrm{~B}+1.5 n \mathrm{H}_{2}$ & $99.9[14]$ & $66.6[14]$ \\
\hline \multicolumn{4}{|c|}{${ }^{\mathrm{a}} \mathrm{FU}=$ formula unit } \\
\hline
\end{tabular}

Following dehydrogenation, interfacial Li atoms were found to strongly adsorb on the oxide surfaces effectively competing with $\mathrm{LiH}$ formation. The $\mathrm{Li}$ interfacial interactions with $\mathrm{Al}_{2} \mathrm{O}_{3}$ and $\mathrm{ZrO}_{2}$ were equally strong in the fully hydrided and dehydrided states, so their net effect of the $\mathrm{LiBH}_{4}$ dehydrogenation was predicted to be insignificant. It is questionable whether the differences between the $\mathrm{LiBH}_{4}$ cluster and the oxide-adsorbed $\mathrm{LiBH}_{4} \Delta H_{\text {deh }}$ values were distinguishable, given the typical error for DFT calculations [13]. If so, they can be interpreted to indicate that oxide adsorption stabilized the fully hydrided state relative to the dehydrided state, making the $\mathrm{LiBH}_{4}$ dehydrogenation reaction slightly more endothermic. The predicted $\mathrm{LiBH}_{4}$ cluster $\Delta H_{\text {deh }}$ was significantly lower than the predicted $\mathrm{LiBH}_{4}$ bulk $\Delta H_{\text {deh }}$ due to the destabilizing surface energy contributions from cluster conformation. Thus, the $\Delta H_{\text {deh }}$ of the isolated $\mathrm{LiBH}_{4}$ cluster and $\mathrm{LiBH}_{4}$ interfaced with the oxides were fortuitously close to the experimental $\Delta H_{\text {deh }}$ value [14], especially considering that ZPE or thermodynamic corrections were not applied. 


\section{First Principles and Thermodynamic Modeling}

\subsection{Calcium Borohydride Interactions with tetragonal $\mathrm{ZrO}_{2}$ Nano-framework}

Zirconia was subsequently down-selected as the baseline system for the development of nanoframework compositions to destabilize the dehydrogenation reactions of very stable, high capacity calcium borohydride, $\mathrm{Ca}\left(\mathrm{BH}_{4}\right)_{2}$. At the outset of this study, the $\mathrm{Ca}\left(\mathrm{BH}_{4}\right)_{2}$ structure was just being refined experimentally [15], and the relative phase stability and thermodynamics had yet to be determined theoretically. The development of the $\mathrm{Ca}\left(\mathrm{BH}_{4}\right)_{2}-\mathrm{ZrO}_{2}$ interface model required atomicbased thermodynamic prediction of the various refined $\mathrm{Ca}\left(\mathrm{BH}_{4}\right)_{2}$ phases to identify the most stable phase, and slab surface energy calculations of this phase to identify the lowest energy surface. Thermodynamic predictions made with the direct method lattice dynamics, using both the VASP and Phonon codes, confirmed the greatest stability for the $\alpha-\mathrm{Ca}\left(\mathrm{BH}_{4}\right)_{2} F d d 2$ phase. Surface energy calculations made with the $\alpha-\mathrm{Ca}\left(\mathrm{BH}_{4}\right)_{2}$ (001), (100), (101) and (110) surfaces identified the (001) surface as the lowest energy surface.

The $\mathrm{ZrO}_{2} \quad P 4_{2} / N M C Z$ tetragonal structural analog to the experimentally-determined tetragonal calcined yttria-stabilized $\mathrm{ZrO}_{2}$ structure was selected to develop surface slabs. The $\mathrm{ZrO}_{2} P 4_{2} / N M C Z$ bulk structure was minimized to the ground state with the VASP code. Slab calculations were then made to optimize the lowest energy $\mathrm{ZrO}_{2} \mathrm{P}_{2} / N M C Z$ (101) surface slab to prepare for developing the $\mathrm{Ca}\left(\mathrm{BH}_{4}\right)_{2}-\mathrm{ZrO}_{2}$ interface. Multiple attempts were made to develop an interface model joining the $\mathrm{Ca}\left(\mathrm{BH}_{4}\right)_{2} F d d 2$ (001) and $\mathrm{ZrO}_{2} P 4_{2} / N M C Z$ (101) surfaces. Here, the challenge was to identify a stable, highly-coordinated, symmetric, stoichiometric cluster representing the $\mathrm{Ca}\left(\mathrm{BH}_{4}\right)_{2} \mathrm{Fdd}(001)$ surface. The best configuration was ultimately found to be a $\mathrm{Ca}_{5} \mathrm{~B}_{10} \mathrm{H}_{40}$ cluster constructed from a 5 layer hexagonal (001) surface slab cell. The interface was formed by aligning the $\mathrm{Ca}_{5} \mathrm{~B}_{10} \mathrm{H}_{40}$ cluster two bottom $\mathrm{Ca}$ atoms with two pendant surface $\mathrm{O}$ atoms on a $\mathrm{ZrO}_{2} P 4_{2} / N M C Z$ (101) $2 \times 3$ slab supercell. The optimized $\mathrm{Ca}\left(\mathrm{BH}_{4}\right)_{2} \mathrm{Fdd} 2(001)-\mathrm{ZrO}_{2} P 4_{2} / N M C Z$ (101) interface is shown in Figure 3.

An atomic model was also created to mimic the experimentally-synthesized tetragonal $\mathrm{Zr}_{0.83} \mathrm{Y}_{0.17} \mathrm{O}_{1.91}$ aerogel material. Simulations were made to identify the most stable Y-dopant substitution sites and corresponding $\mathrm{O}$ vacancy formation in the $\mathrm{ZrO}_{2} P 4_{2} / N M C Z$ (101) 3 layer slabs, where one $\mathrm{O}$ vacancy was formed for every two $\mathrm{Y}^{+3}$ substitutions for $\mathrm{Zr}^{+4}$ in order to maintain charge neutrality. An interface was formed with the $\mathrm{Ca}_{5} \mathrm{~B}_{10} \mathrm{H}_{40}$ cluster and the $\mathrm{Y}$-doped $\mathrm{Zr}_{30} \mathrm{Y}_{6} \mathrm{O}_{69} P 4_{2} / N M C Z$ (101) $2 \times 3$ supercell. The $\mathrm{Ca}\left(\mathrm{BH}_{4}\right)_{2}$ adsorption configuration on $\mathrm{Zr}_{30} \mathrm{Y}_{6} \mathrm{O}_{69}$ was comparable to the $\mathrm{Ca}\left(\mathrm{BH}_{4}\right)_{2}-$ $\mathrm{ZrO}_{2}$ interface configuration shown in Figure 3. The same local atomic interactions are noted, with two interfacial hydride $\mathrm{Ca}$ ions directly bonded to $\mathrm{ZrO}_{2}$ surface bridging $\mathrm{O}$ atoms and weaker interactions of two interfacial $\mathrm{H}$ atoms with undercoordinated surface $\mathrm{Zr}$ atoms. The adsorption enthalpies for $\mathrm{Ca}\left(\mathrm{BH}_{4}\right)_{2}$ on the $\mathrm{ZrO}_{2}$ and $\mathrm{Zr}_{30} \mathrm{Y}_{6} \mathrm{O}_{69}$ (101) surfaces, were -138.9 and $-120.6 \mathrm{~kJ} / \mathrm{mole}$, respectively. The adsorption of the $\mathrm{Ca}\left(\mathrm{BH}_{4}\right)_{2}$ cluster was weakened by the reduced delocalization of cluster excess electron charge on the lower coordination $\mathrm{Zr}_{30} \mathrm{Y}_{6} \mathrm{O}_{69}$ surface. 


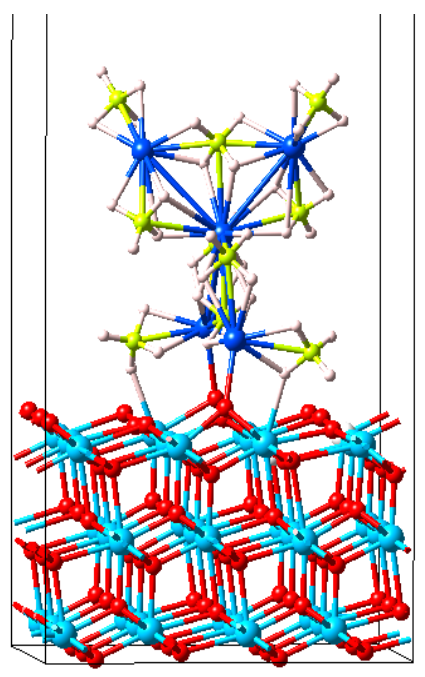

Figure 3: $\mathrm{Ca}\left(\mathrm{BH}_{4}\right)_{2} \mathrm{Fdd2}(001)-\mathrm{ZrO}_{2} P 4_{2} / N M C Z$ (101) interface. The colors of the atoms are as follows: $\mathrm{Zr}$ - turquoise, $\mathrm{O}$ - red, Ca- royal blue, B- chartreuse, and $\mathrm{H}$-white.

The $\mathrm{Ca}\left(\mathrm{BH}_{4}\right)_{2}$ phase is unique in that is can possibly dehydrogenate through one of three reactions, as shown in Table 3.

Table 3: Potential $\mathrm{Ca}\left(\mathrm{BH}_{4}\right)_{2}$ Dehydrogenation Reactions

\begin{tabular}{|l|c|c|}
\hline $\begin{array}{l}\text { Solid-State } \mathrm{Ca}\left(\mathrm{BH}_{4}\right)_{2} \text { Dehydrogenation } \\
\text { Products }\end{array}$ & $\begin{array}{c}\mathrm{Wt} \% \mathrm{H}_{2} \\
\text { Release }\end{array}$ & $\begin{array}{c}\Delta H_{\mathrm{deh}} \\
\text { ground state electronic } \\
{\left[\mathrm{kJ} / \mathrm{mole}_{\mathrm{Ca}}\left(\mathrm{BH}_{4}\right)_{2}\right]}\end{array}$ \\
\hline $5 / 6 \mathrm{CaH}_{2}+{ }^{1 /}{ }_{6} \mathrm{CaB}_{12} \mathrm{H}_{12}+13 /{ }_{6} \mathrm{H}_{2}$ & 6.26 & 140.60 \\
\hline $2 /{ }_{3} \mathrm{CaH}_{2}+1 /{ }_{3} \mathrm{CaB}_{6}+10 /{ }_{3} \mathrm{H}_{2}$ & 9.63 & 202.98 \\
\hline $\mathrm{CaH}_{2}+2 \mathrm{~B}+3 \mathrm{H}_{2}$ & 8.67 & 241.09 \\
\hline
\end{tabular}

The values compare well to other predictions reported in the literature [16-Error! Reference source not found.]. The first dehydrogenation reaction to form the $\mathrm{CaH}_{2}$ and $\mathrm{CaB}_{12} \mathrm{H}_{12}$ products is the most thermodynamically accessible reaction, however, only generates partial $\mathrm{H}_{2}$ release. The second dehydrogenation reaction to form the $\mathrm{CaH}_{2}$ and $\mathrm{CaB}_{6}$ products, is the most desirable reaction in terms of total $\mathrm{H}_{2}$ release and has an intermediate enthalpy value. The third reaction is the least accessible reaction.

The interactions of the dehydrogenation products, including: $\mathrm{CaH}_{2}, \mathrm{CaB}_{6}, \mathrm{Ca}, \mathrm{B}, \mathrm{CaB}_{12} \mathrm{H}_{12}$, and $\mathrm{H}_{2}$, with the $\mathrm{ZrO}_{2}$-type surfaces were surveyed in order to predict $\mathrm{Ca}\left(\mathrm{BH}_{4}\right)_{2}$ dehydrogenation behavior in the presence of the $\mathrm{ZrO}_{2}$ frameworks. The atomic simulations for a 5 formula unit $\mathrm{Ca}\left(\mathrm{BH}_{4}\right)_{2}$ cluster and its possible decomposition products interacting with the $\mathrm{ZrO}_{2}$ surface did not reveal new dehydrogenation reaction mechanisms in addition to those shown in Table 3, or other competing side reactions that could lead to the loss of $\mathrm{H}_{2}$ storage capacity. The adsorption enthalpies, $\Delta H_{\mathrm{ads}}$, for the most favorable dehydrogenation products on the $\mathrm{ZrO}_{2}$ (101) surface is shown in Table 4, where the 


\section{First Principles and Thermodynamic Modeling}

adsorption of other possible dehydrogenation product phases, including: $\mathrm{CaB}_{6}, \mathrm{BH}_{4}$, $\mathrm{B}$, and $\mathrm{H}$, were not predicted to be favorable. To facilitate comparison, the adsorption enthalpies are referenced to the constituent element standard state enthalpies, and normalized per number of atoms.

Table 4: Most Favorable Adsorption Enthalpies, $\Delta H_{\text {ads }}$, of $\mathrm{Ca}\left(\mathrm{BH}_{4}\right)_{2}$-Derived Phases Adsorbed on undoped, doped and Pt-loaded $\mathrm{ZrO}_{2}$ (101) surfaces. Adsorption enthalpies were references to the constituent element standard states.

\begin{tabular}{|c|c|c|c|}
\hline \multirow{2}{*}{ Adsorbates } & $\begin{array}{c}\mathrm{ZrO}_{2} \\
P 4_{2} / N M C Z \\
(101)\end{array}$ & $\begin{array}{c}\mathrm{Zr}_{30} \mathrm{Y}_{6} \mathrm{O}_{69} \\
(101)\end{array}$ & $\begin{array}{c}\mathrm{Pt}_{10} * \\
\mathrm{ZrO}_{2} \\
P 4_{2} / N M C Z \\
(101)\end{array}$ \\
\hline & \multicolumn{2}{|c|}{$\Delta H_{\text {ads }}$} & (kJ/mole*atom) \\
\hline $\mathrm{CaB}_{12} \mathrm{H}_{12}$ & -27.2 & N.D. & -35.5 \\
\hline $\mathrm{CaH}_{2}$ & -55.3 & -54.3 & -127.0 \\
\hline $\mathrm{BH}_{3}$ & -25.2 & N.D. & -26.2 \\
\hline $\mathrm{Ca}$ & -44.7 & N.D. & -242.2 \\
\hline
\end{tabular}

Dehydrogenation product interactions with the nano-frameworks have the potential not only to influence the selectivity towards a particular dehydrogenation reaction, but also the reversibility and the amount of the hydrogenation released by that reaction. The strongest adsorbing full dehydrogenation product on both surfaces was found to be $\mathrm{CaH}_{2}$, reinforcing the likelihood of the most thermodynamically accessible reaction mechanism, the first reaction in Table 4, to occur. On both the undoped and the $\mathrm{Y}$-doped $\mathrm{ZrO}_{2}$ surfaces, the $\mathrm{Ca}$ adsorbed in a 3-fold $\mathrm{O}$ hollow, and the bonded $\mathrm{H}$ interact with adjoining metal ions at the surface.

The $\mathrm{Ca}\left(\mathrm{BH}_{4}\right)_{2}$ dehydrogenation reactions were calculated with the most favorable dehydrogenation $\mathrm{CaH}_{2}$ product adsorbed on the $\mathrm{ZrO}_{2}$ surface, and the remaining unadsorbed dehydrogenation products as separate bulk phase models. These calculations revealed that the relative favorability of the three $\mathrm{Ca}\left(\mathrm{BH}_{4}\right)_{2}$ dehydrogenation reactions was not changed in the presence of the $\mathrm{ZrO}_{2}(101)$. However, all of the dehydrogenation enthalpies were slightly increased in the presence of the $\mathrm{ZrO}_{2}$ surface. For example, the $\Delta H_{\text {deh }}$ for the most thermodynamically accessible dehydrogenation reaction is compared in Table 5 for the 5 formula unit $\mathrm{Ca}\left(\mathrm{BH}_{4}\right)_{2}$ cluster alone and adsorbed on the $\mathrm{ZrO}_{2}(101)$ surface. The $\Delta H_{\text {deh }}$ of $\mathrm{Ca}\left(\mathrm{BH}_{4}\right)_{2}$ in the presence of the $\mathrm{ZrO}_{2}$ (101) was slightly stabilized, on the order of +14 $\mathrm{kJ} / \mathrm{mole} \mathrm{H}_{2}$. This can be interpreted to indicate that the interactions of $\mathrm{Ca}\left(\mathrm{BH}_{4}\right)_{2}$ with the undoped $\mathrm{ZrO}_{2}$ framework will render $\mathrm{Ca}\left(\mathrm{BH}_{4}\right)_{2}$ less thermodynamically reversible. 


\section{First Principles and Thermodynamic Modeling}

Table 5: Predicted dehydrogenation enthalpies for neat $\mathrm{Ca}\left(\mathrm{BH}_{4}\right)_{2}$ in bulk and cluster form, and for $\mathrm{Ca}\left(\mathrm{BH}_{4}\right)_{2} 5$ formula unit cluster adsorbed on $\mathrm{ZrO}_{2}$ and $\mathrm{Zr}_{30} \mathrm{Y}_{6} \mathrm{O}_{69}$, with the least endothermic dehydrogenation reaction forming the products indicated.

\begin{tabular}{|l|c|}
\hline Most Favorable $\mathrm{Ca}\left(\mathrm{BH}_{4}\right)_{2}$ Dehydrogenation Reactions & $\begin{array}{c}\Delta H_{\text {deh }} \\
\left(\mathrm{kJ} / \mathrm{mole}_{2}\right)\end{array}$ \\
\hline$n \times \mathrm{Ca}\left(\mathrm{BH}_{4}\right)_{2} \mathrm{Fdd} 2$ bulk $\rightarrow n \times\left[45 / 6 \mathrm{CaH}_{2}+1 / 6 \mathrm{CaB}_{12} \mathrm{H}_{12}+21 / 6 \mathrm{H}_{2}\right]$ & 64.9 \\
\hline $\mathrm{Ca}_{5}\left(\mathrm{BH}_{4}\right)_{10}$ cluster $\rightarrow 4{ }_{6} / 6 \mathrm{CaH}_{2}+5 / 6 \mathrm{CaB}_{12} \mathrm{H}_{12}+10{ }_{6} \mathrm{H}_{2}$ & 28.1 \\
\hline $\mathrm{Ca}_{5}\left(\mathrm{BH}_{4}\right)_{10} * \mathrm{ZrO}_{2} \rightarrow \mathrm{CaH}_{2} * \mathrm{ZrO}_{2}+3{ }^{1} / 6 \mathrm{CaH}_{2}+5 / 6 \mathrm{CaB}_{12} \mathrm{H}_{12}+105 / 6 \mathrm{H}_{2}$ & 41.7 \\
\hline $\mathrm{Ca}_{5}\left(\mathrm{BH}_{4}\right)_{10} * \mathrm{Zr}_{30} \mathrm{Y}_{6} \mathrm{O}_{69} \rightarrow \mathrm{CaH}_{2} * \mathrm{ZrO}_{2}+31 / 6 \mathrm{CaH}_{2}+5 / 6 \mathrm{CaB}_{12} \mathrm{H}_{12}+105 / 6 \mathrm{H}_{2}$ & 40.3 \\
\hline $\mathrm{Ca}_{5}\left(\mathrm{BH}_{4}\right)_{10} * \mathrm{Pt} * \mathrm{ZrO}_{2} \rightarrow \mathrm{CaH}_{2} * \mathrm{Pt} * \mathrm{ZrO}_{2}+31 / 6 \mathrm{CaH}_{2}+5 / 6 \mathrm{CaB}_{12} \mathrm{H}_{12}+105 / 6 \mathrm{H}_{2}$ & 47.9 \\
\hline
\end{tabular}

\subsection{Calcium Borohydride Interactions with Pt-loaded $\mathrm{ZrO}_{2}$ Nano-framework}

Atomic modeling investigations explored the role that the loading of heterogeneous catalysts, such as $\mathrm{Pt}$, on nano-framework surfaces could play for facilitating rehydrogenation of $\mathrm{Ca}\left(\mathrm{BH}_{4}\right)_{2}$ and other hydrides. This is a different catalysis approach than the well-known solid-state catalysis of hydrides by doping, which is akin to homogeneous-like catalysis. Here the catalysis ion remains close to the first-order reaction front as the hydride is dissociated or reformed. This concept was simulated by loading the $\mathrm{ZrO}_{2} P 4_{2} / N M C Z$ (101) slab with a Pt nano-raft, in the favorable configuration of a 10 atom $\mathrm{Pt}$ hemi-cuboctahedral cluster. The composite of the Pt nano-raft was bonded through its lower (111) surface to the $\mathrm{ZrO}_{2}$ slab was minimized to the structure shown in Figure 4. Surveys were then conducted on Pt nano-raft / $\mathrm{ZrO}_{2} P 4_{2} / N M C Z$ (101) structure to look at: a) adsorption interactions with $\mathrm{Ca}\left(\mathrm{BH}_{4}\right)_{2}$ and its dehydrogenation intermediates, b) $\mathrm{H}$ dissociation on $\mathrm{Pt}$ and spillover onto $\mathrm{ZrO}_{2}$, and c) rehydrogenation of $\mathrm{Ca}\left(\mathrm{BH}_{4}\right)_{2}$ dehydrogenation products.

Atomic simulations revealed that the presence of the Pt nano-raft loaded on the $\mathrm{ZrO}_{2}(101)$ surface dramatically affected the adsorption of the $\mathrm{Ca}\left(\mathrm{BH}_{4}\right)_{2}$-related phases. The $5 \mathrm{FU} \mathrm{Ca}\left(\mathrm{BH}_{4}\right)_{2}$ cluster bonded over the Pt-loaded $\mathrm{ZrO}_{2}$ (101) with an adsorption enthalpy of $-420.7 \mathrm{~kJ} / \mathrm{mole}$, which was almost three times stronger than on $\mathrm{ZrO}_{2}$ (101). The adsorption enthalpies for the most favorable adsorbates are given in Table 4. The electron-withdrawing nature of the adhered Pt nano-raft increased the adsorption of the most favorable $\mathrm{CaH}_{2}$ and $\mathrm{Ca}$ dehydrogenation products 2-fold and 5fold, respectively. The increased adsorption interactions of the fully hydrided and dehydrided $\mathrm{Ca}\left(\mathrm{BH}_{4}\right)_{2}$ occurred in a relative manner so that overall impact the $\mathrm{Ca}\left(\mathrm{BH}_{4}\right)_{2}$ dehydrogenation enthalpy was increased slightly compared to that on the $\mathrm{ZrO}_{2}$ (101) surface without the loaded Pt (see Table 5). 


\section{First Principles and Thermodynamic Modeling}

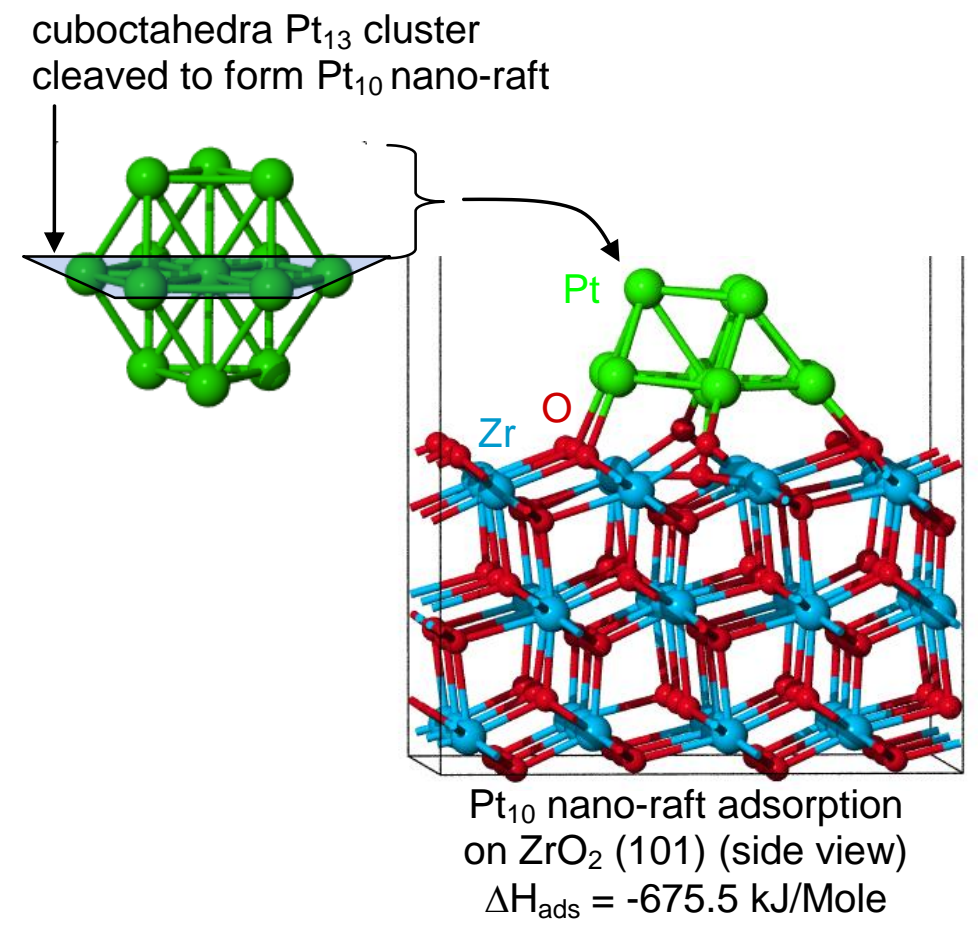

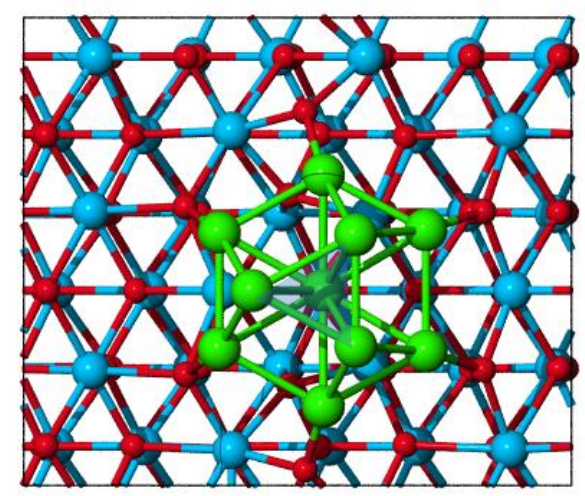

$\mathrm{Pt}_{10}$ nano-raft with most stable (111) upper surface and interfacial plane (top view)

Figure 4: The Pt nano-raft configuration on $\mathrm{ZrO}_{2}$ (101) surface. The atoms are colored lime green for $\mathrm{Pt}$, aqua for $\mathrm{Zr}$, and red for $\mathrm{O}$.

The dehydrogenation product adsorption enthalpies were further enhanced by $\mathrm{H}$ adsorption on the $\mathrm{Pt}$ nano-raft. The dissociative adsorption of $\mathrm{H}_{2}$ on the $\mathrm{ZrO}_{2}$-supported Pt nano-raft was predicted to be spontaneous and very favorable, with the $\Delta H_{\text {ads }}$ of $-169.0 \mathrm{~kJ} / \mathrm{mol}$ for adsorption of $2 \mathrm{H}$ atoms. This compared well with other reported simulation and experimentation results [Error! Reference source not found.]. Atomic simulations revealed that the adsorption of up to $24 \mathrm{H}$ on the 10 atom Pt nanoraft was favorable, with the average $\mathrm{H} \Delta H_{\text {ads }}$ of $-36 \mathrm{~kJ} / \mathrm{mol}^{*}$ atom upon $\mathrm{H}$ saturation. Additional $\mathrm{H}$ adsorption on the surrounding $\mathrm{ZrO}_{2}$ support is favorable in the presence of the Pt nano-raft, after $\mathrm{H}$ saturation especially upon $\mathrm{H}$-saturation of the Pt nano-raft. The adsorption of two more $\mathrm{H}$ on the surrounding $\mathrm{ZrO}_{2}$ had an adsorption enthalpy of $-66 \mathrm{~kJ} / \mathrm{mol}^{*} \mathrm{H}$ atom in the presence of the $\mathrm{H}$ saturated Pt nano-raft. This is a manifestation of $\mathrm{H}$ spillover behavior, where the $\mathrm{Pt}$ nano-catalyst facilitates more $\mathrm{H}$ adsorption than would be possible just due to the number of active catalyst sites on the Pt nano-raft. The $\Delta H_{\text {ads }}$ of $\mathrm{Ca}$ and $\mathrm{CaH}_{2}$ was most enhanced adjacent to the $\mathrm{H}$-saturated $\mathrm{ZrO}_{2}$ supported $\mathrm{Pt}$ nano-raft, up to ten-times that simulated on $\mathrm{ZrO}_{2}$ (101) alone. Here the reaction enthalpy for $\mathrm{H}$ adsorption on $\mathrm{Ca}$ was very small, so that it is envisioned that the adsorbed $\mathrm{Ca}$ could act as a H-shuttle between the Pt nano-raft and other adsorbed species on the surface.

The possible role that the Pt nano-raft could play for facilitating rehydrogenation behavior was demonstrated for the reverse of the second $\mathrm{Ca}\left(\mathrm{BH}_{4}\right)_{2}$ dehydrogenation reaction in Table 3 . Here, the adsorption of the $\mathrm{CaB}_{6}$ product on the $\mathrm{ZrO}_{2}$ surface was predicted to be favorable only in the presence of the $\mathrm{H}$-saturated $\mathrm{Pt}$ nano-raft. In this case, minimization showed that the adsorbed $\mathrm{Ca}$ acted as a shuttle to facilitate rehydrogenation of the adsorbed $\mathrm{B}_{6}$ octahedron. This is a likely precursor stage for formation and oligomerization of the $\mathrm{BH}_{4}$ building blocks. 


\section{First Principles and Thermodynamic Modeling}

In summary, when interfaced with the $\mathrm{ZrO}_{2}$ (101) surface, $\mathrm{Ca}\left(\mathrm{BH}_{4}\right)_{2}$ was predicted to have an increased dehydrogenation enthalpy of almost $+14 \mathrm{~kJ} / \mathrm{m} \mathrm{H}_{2}$ for the most accessible dehydrogenation and the same order of relative favorability for the known dehydrogenation reactions. The atomic modeling demonstrated the utility of $\mathrm{H}_{2}$ activation catalysts, such as $\mathrm{Pt}$, to facilitate formation, adsorption, and transfer of atomic $\mathrm{H}$, and to enhance binding and rehydrogenation of dehydrided phases.

\subsection{Sodium Titanium Borohydride Interactions on Functionalized $\mathrm{ZrO}_{2}$}

A number of very high capacity complex hydride compounds based on transition metal cations can only exist when they are coordinated with chemical ligands (eg., $\mathrm{NaTi}\left(\mathrm{BH}_{4}\right)_{4}$ stabilized with dimethoxyethane). Although these ligands provide stabilization by associative interactions with hydride complexes in the outer coordination spheres, they are readily volatilized upon dehydrogenation and do not reassociate to facilitate hydride reassembly upon rehydrogenation. Thus, they are not effective in promoting thermodynamic reversibility of hydrogen storage media. For this reason, atomic simulations are being used in this project to probe the concept of confining and stabilizing unstable, high capacity hydrogen storage media in chemically-modified inorganic nanoframeworks, to replace the ligand-hydride complexation approach.

Atomic simulations were made to survey a wide-range of candidate chemical moieties to functionalize tetragonal $\mathrm{ZrO}_{2}$ nano-frameworks, which were capable of interactions ranging from weak physi-sorption to stronger chemi-sorption bonding. All of the selected candidates had bifunctional chemical groups, to enable simultaneous interactions with both the nano-framework and hydride nano-crystallite surfaces. The candidates included: dimethoxyethane $(\mathrm{DME})=$ $\mathrm{CH}_{3} \mathrm{OCH}_{2} \mathrm{CH}_{2} \mathrm{OCH}_{3}$, ethylenediamine $(\mathrm{EDA})=\mathrm{H}_{2} \mathrm{NCH}_{2} \mathrm{CH}_{2} \mathrm{NH}_{2}$, triethylenediamine $($ TEDA) $=$ $\mathrm{C}_{6} \mathrm{H}_{12} \mathrm{~N}_{2}$, hexamethylenetetramine $(\mathrm{HMTA})=\left(\mathrm{CH}_{2}\right)_{6} \mathrm{~N}_{4}$, oxalic acid $(\mathrm{OXA})=\mathrm{HOOCCOOH}$, and glycolic acid $(\mathrm{GLA})=\mathrm{HOOCCH}_{2} \mathrm{OH}$. The first candidate, DME, was the same ligand that effectively stabilizes the unstable high capacity hydride, $\mathrm{NaTi}\left(\mathrm{BH}_{4}\right)_{4}$, through associative physi-sorption interactions with $\mathrm{O}$ lone-pair orbitals, in the absence of nano-framework surfaces. The evaluation of this ligand served as a benchmark for the interactions with the other chemical moieties, as well as to elucidate the ligand-hydride stabilization mechanism. The amine candidates: EDA, TEDA, and HMTA, are also capable of associative interactions through $\mathrm{N}$ lone pair orbitals, where other Lewis base amines have been found to effective for stabilization of hydride complexes, such as alane [17]. Finally, stronger interacting carboxylic acid and alcohol groups capable of chemi-sorption bonding and condensing on the $\mathrm{ZrO}_{2}$ surface, are probed with the OXA and GLA chemical moieties.

Four sets of calculations were made to probe the balance of interactions of each chemical moiety within a $\mathrm{NaTi}\left(\mathrm{BH}_{4}\right)_{4}$ hydride-loaded $\mathrm{ZrO}_{2}$ nano-framework, to evaluate the influence of chemical modification on the $\mathrm{NaTi}\left(\mathrm{BH}_{4}\right)_{4}$ thermodynamic reversibility. Representative models for the first three sets of calculations are shown for the EDA chemical moiety in Figure 5. 


\section{First Principles and Thermodynamic Modeling}

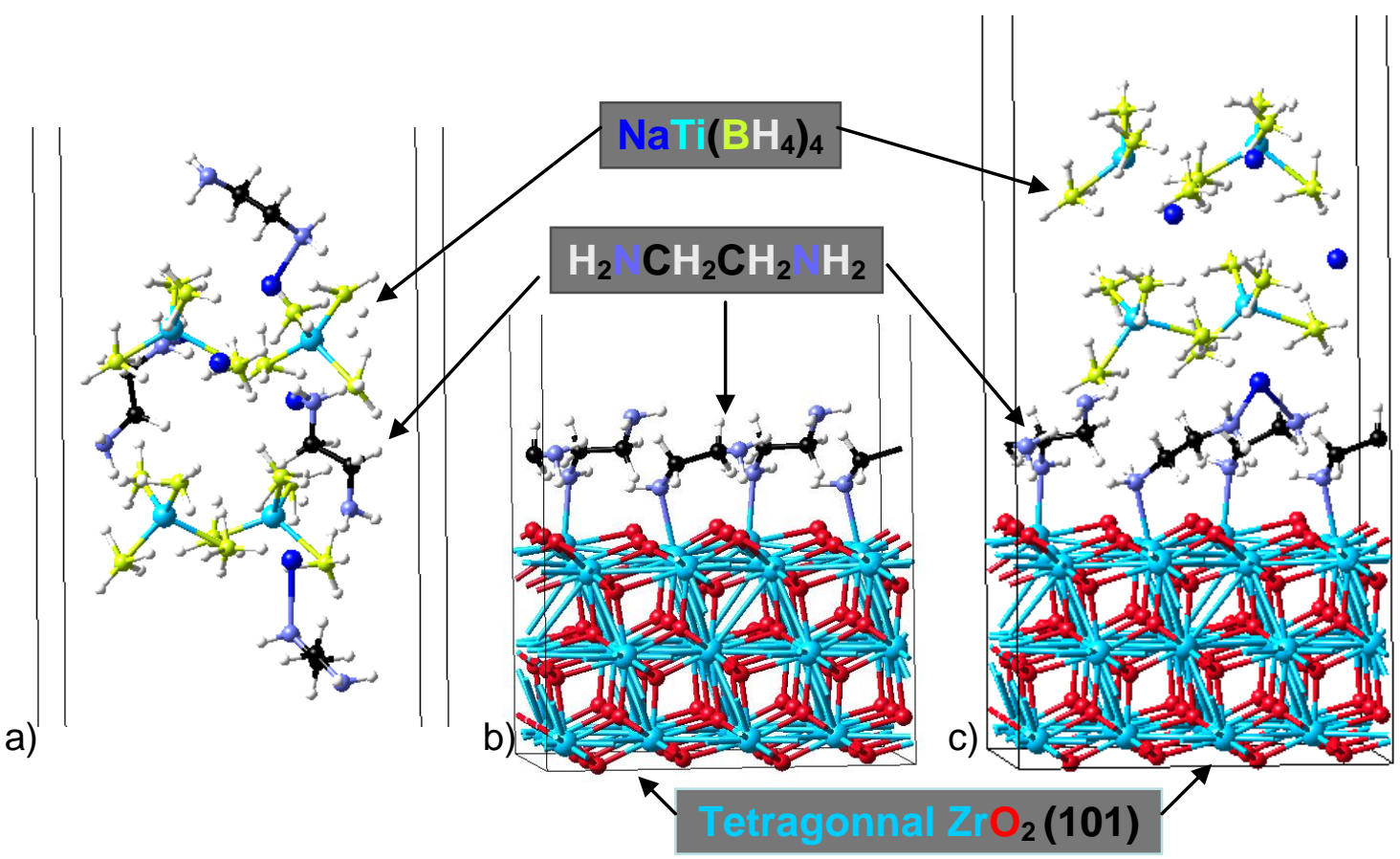

Figure 5: Atomic models for the survey of ethylenediamine (EDA) chemical moiety interactions with a) $\left[4 \mathrm{NaTi}\left(\mathrm{BH}_{4}\right)_{4}\right]$ cluster, b) $\mathrm{ZrO}_{2}(101)$ surface, and c) at the $\left[4 \mathrm{NaTi}\left(\mathrm{BH}_{4}\right)_{4}\right]$ cluster- $\mathrm{ZrO}_{2}(101)$ interface.

First, calculations were made to survey the functional group interactions with a $\mathrm{NaTi}\left(\mathrm{BH}_{4}\right)_{4}$ cluster alone, to predict the strength of their bonding interactions and stabilization of the hydride. Second, calculations were made to survey the functional groups modifying the surface properties of the tetragonal $\mathrm{ZrO}_{2}$ nano-framework, represented as a slab. The major goal here was to discern the competitive interactions of the hydride and the nano-frameworks with the chemical moieties, where it was desirable for stronger interactions to occur with the nano-framework for effective moiety anchoring and surface chemical modification. However, for complete reversibility, the second unanchored functional group on each bifunctional moiety must also play a role in circumventing irreversible product formation upon dehydrogenation, in addition to stabilizing the fully-hydrided state. Third, calculations were made to evaluate the influence of chemical modification at the $\mathrm{NaTi}\left(\mathrm{BH}_{4}\right)_{4}-\mathrm{ZrO}_{2}$ hydride-loaded nano-framework interface, examining both the adsorptive interactions and hydride reversibility. Fourth, calculations evaluate hydride decomposition by probing the interactions of possible decomposition products: $\mathrm{Na}, \mathrm{NaH}, \mathrm{Ti}, \mathrm{TiH}_{2}, \mathrm{~B}$, etc. with the bare $\mathrm{ZrO}_{2}$ surface, the chemically-modified $\mathrm{ZrO}_{2}$ surfaces, and with the isolated chemical moieties. The most stable scenario for the decomposition product formation is used to represent the dehydrogenated state. Here, the enthalpies for the most favorable adsorbed products are used, as well as the most stable phase models for the remainder of the products not adsorbed, to account for mass balance of the dehydrogenation reactions. The dehydrogenation reversibility was determined as the difference between the stoichiometrically equivalent fully hydrided chemically-modified $\mathrm{NaTi}\left(\mathrm{BH}_{4}\right)_{4}-\mathrm{ZrO}_{2}$ interface and the most stable dehydrogenated phases.

The minimized structures of the functionalizing agents complexed with a $4\left[\mathrm{NaTi}\left(\mathrm{BH}_{4}\right)_{4}\right]$ hydride cluster, with the $\mathrm{ZrO}_{2}$ (101) surface, and at the $4\left[\mathrm{NaTi}\left(\mathrm{BH}_{4}\right)_{4}\right]-\mathrm{ZrO}_{2}$ (101) interface, were used to 


\section{First Principles and Thermodynamic Modeling}

evaluate competitive adsorption interactions. The complexation strengths were determined from the adsorption enthalpies, $\Delta H_{\mathrm{ads}}$, shown in Table 6 , and were defined as

$$
\Delta H_{\text {ads }}=H_{\text {functionalized complexed entity }}-\left(H_{\text {unfunctionalized entity }}+H_{\text {functionalizing agent }}\right)
$$

where the $\mathrm{H}$ were the model ground state enthalpies, and the functionalized entities were the hydride, $\mathrm{ZrO}_{2}$, or hydride $-\mathrm{ZrO}_{2}$ interface. The results showed that the partially shielded lone pair orbitals of EDA and DME functionalizing agents had the strongest interactions with the $\mathrm{NaTi}\left(\mathrm{BH}_{4}\right)_{4}$ hydride. The most polar OXA and GLA carboxyl endgroups formed the strongest bonds with the $\mathrm{ZrO}_{2}$ surface. The favorability of these functional groups at the $4\left[\mathrm{NaTi}\left(\mathrm{BH}_{4}\right)_{4}\right]-\mathrm{ZrO}_{2}$ (101) interface corresponded mainly to the strength of the $\mathrm{ZrO}_{2}$ interaction, where the weakest adsorption was found for DME and the strongest adsorption was found for OXA and GLA.

Table 6: Adsorption enthalpies, $\Delta H_{\text {ads }}$, for complexation of functionalizing agents with the hydride, $\mathrm{ZrO}_{2}$, and their interface.

\begin{tabular}{|l|c|c|c|}
\hline Functionalizing & Functionalize & Functionalize & Functionalize \\
\hline \multicolumn{1}{|c|}{ Agent } & $\mathrm{NaTi}\left(\mathrm{BH}_{4}\right)_{4}$ & $\mathrm{ZrO}_{2}$ & $\mathrm{NaTi}\left(\mathrm{BH}_{4}\right)_{4}-\mathrm{ZrO}_{2}$ \\
\hline & \multicolumn{3}{|c|}{$\Delta \mathrm{H}_{\text {ads total }}(\mathrm{kJ} / \mathrm{mole})$} \\
\hline & -305.33 & -55.20 & 104.06 \\
\hline DME & -235.8 & -536.4 & -453.5 \\
\hline OXA & -338.5 & -302.6 & -377.2 \\
\hline GLA & -293.1 & -565.0 & -410.92 \\
\hline HMTA & -177.1 & -172.3 & -309.1 \\
\hline TEDA & -72.54 & -129.80 & -236.77 \\
\hline
\end{tabular}

The dehydrogenation reversibility was determined as the difference between the stoichiometrically equivalent fully hydrided chemically-modified $\mathrm{NaTi}\left(\mathrm{BH}_{4}\right)_{4}-\mathrm{ZrO}_{2}$ interface and the most stable dehydrogenated state. Here, the enthalpies for the most favorable adsorbed products, as well as the most stable models for the remainder of the unadsorbed products, were used to account for mass balance of the dehydrogenation reactions. The first scenario evaluated was the dehydrogenation of the functionalized $\mathrm{NaTi}\left(\mathrm{BH}_{4}\right)_{4}$ hydride in the absence of the $\mathrm{ZrO}_{2}$ framework. Here the decomposition products for each $\mathrm{NaTi}\left(\mathrm{BH}_{4}\right)_{4}$ formula unit: $\mathrm{NaH}$, $\mathrm{TiH}_{2}, 4 \mathrm{~B}$, and $6.5 \mathrm{H}_{2}$, were assumed not to be associated with the functionalizing agent upon dehydrogenation. Depending on the competitive interactions of the chemical moieties and the hydride decomposition products with the $\mathrm{ZrO}_{2}$ surface, two other possible scenarios could represent the most stable dehydrogenated state. The second scenario was that all the functionalizing agents were adsorbed on the $\mathrm{ZrO}_{2}$ surface upon hydride decomposition, blocking any adsorption of decomposition products. Here the hydride decomposition products were also assumed not to be associated with the functionalizing agent. The third scenario was that the most stable dehydrogenated phases: $2 \mathrm{Na}$ and $2 \mathrm{H}$ atoms, equivalent to the dissociative adsorption of $2 \mathrm{NaH}$ decomposition products, were adsorbed on $\mathrm{ZrO}_{2}$. It was assumed that the charge redistribution and the blocking of surface sites from their adsorption preempted the adsorption of functionalizing agents. The remaining decomposition products and the functionalizing agents were 


\section{First Principles and Thermodynamic Modeling}

assumed not to be associated with the surface, and for simplicity, not with each other. (Associations of the ligands with the dehydrogenation products were not found to be significant).

The thermodynamic reversibility of the functionalized hydride- $\mathrm{ZrO}_{2}$ interfaces was assessed from the dehydrogenation enthalpies, $\Delta H_{\text {deh }}$, shown in Table 7 , which were reported in units of $\mathrm{kJ} / \mathrm{mole}_{2}$ desorbed. The $\Delta H_{\text {deh }}$ were determined for the first scenario as

$\Delta H_{\text {deh }}=H_{\text {functionalizing agents }}+\Sigma\left[H_{\text {dehydrogenation products }}\right]-H_{\text {functionalized NaTi(BH4)4 }}$

for the second scenario as

$\Delta H_{\text {deh }}=H_{\mathrm{ZrO} 2+\text { adsorbed functionalizing agents }}+\Sigma\left[H_{\text {dehydrogenation products }}\right]-H_{\text {functionalized NaTi(BH4)4 }}-\mathrm{ZrO} 2$

and for the third scenario as

$\begin{aligned} \Delta H_{\mathrm{deh}} & =H_{\mathrm{ZrO} 2+2 \mathrm{Na}+2 \mathrm{H} \text { adsorbed }}+\Sigma\left[H_{\text {functionalizing agents }+ \text { remaining dehydrogenation products }}\right] \\ & -E_{\text {functionalized } \mathrm{NaTi}(\mathrm{BH} 4) 4-\mathrm{ZrO} 2}\end{aligned}$

where the scenarios utilized balanced reactions to stoichiometrically account for all species. The dehydrogenation enthalpy of uncomplexed $\mathrm{NaTi}\left(\mathrm{BH}_{4}\right)_{4}$ was used as a reference point to assess the reversibility of the various functionalized $\mathrm{NaTi}\left(\mathrm{BH}_{4}\right)_{4}$ dehydrogenation reactions. Experimentally, a complexing agent, such as DME, is required for the $\mathrm{NaTi}\left(\mathrm{BH}_{4}\right)_{4}$ synthesis. Predictions show that the unstable hydride without a complexing agent has a $\Delta H_{\text {deh }}$ of $26 \mathrm{~kJ} / \mathrm{mole}_{2}$, so the goal was to find complexing agents that moderately increase the $\Delta H_{\text {deh }}$ values for improved reversibility. The association of the $\mathrm{NaTi}\left(\mathrm{BH}_{4}\right)_{4}$ hydride with the $\mathrm{ZrO}_{2}$ surface, in the absence of a functionalizing agent, is predicted to slightly stabilize the hydride reversibility. For each of the complexing agents, the scenario corresponding to the lowest $\Delta H_{\text {deh }}$ value was the most favorable, where the least endothermic value was judged to be the most thermodynamically accessible. The most favorable predictions showed that the functionalizing agents only imparted slight increases in $\Delta H_{\text {deh }}$ values or thermodynamic stabilization for two of the functionalizing agents, EDA and GLA, associated with the $\mathrm{NaTi}\left(\mathrm{BH}_{4}\right)_{4}-\mathrm{ZrO}_{2}$ interface. The EDA moiety has a balanced interaction with both the $\mathrm{NaTi}\left(\mathrm{BH}_{4}\right)_{4}$ and $\mathrm{ZrO}_{2}$ (see Table I), and the EDA complexed interface was shown to dissociate to a functionalized surface. The HMTA and TEDA moieties could not compete with the more polar $\mathrm{Na} / \mathrm{H}$ dehydrogenation products for adsorption onto the surface. The most favorable scenarios for all the remaining functionalizing agents: DME, OXA, and GLA, showed lower $\Delta H_{\text {deh }}$ values, indicating an overall destabilizing influence on thermodynamic reversibility. The HMTA offers the best stabilization within the nano-framework, but may volatilize with the $\mathrm{H}_{2}$ product. 


\section{First Principles and Thermodynamic Modeling}

Table 7: Dehydrogenation enthalpies, $\Delta H_{\text {deh }}$, for functionalized NaTi $\left(\mathrm{BH}_{4}\right)_{4}$ or NaTi $\left(\mathrm{BH}_{4}\right)_{4}-\mathrm{ZrO}_{2}$ dehydrogenated to unadsorbed or adsorbed dehydrogenation products. The most favorable scenarios are shown in bold.

\begin{tabular}{|l|l|l|l|}
\hline Functionalizing & $1^{\text {st }}$ Scenario & $2^{\text {nd }}$ Scenario & $3^{\text {rd }}$ Scenario \\
\hline Agent & Functionalized & Functionalized & Functionalized \\
\hline & NaTi $\left(\mathrm{BH}_{4}\right)_{4}$ & $\mathrm{NaTi}\left(\mathrm{BH}_{4}\right)_{4}-\mathrm{ZrO}_{2}$ & $\mathrm{NaTi}\left(\mathrm{BH}_{4}\right)_{4}-\mathrm{ZrO}_{2}$ \\
\hline & Deh. to product & Deh. to funct. surface & Deh. to 2Na/2H ads. surface \\
\hline & \multicolumn{3}{|c|}{$\Delta H_{\text {deh }}$} \\
\hline & \multicolumn{3}{|c|}{$\left(\mathrm{kJ} / \mathrm{mole}_{2}\right)$} \\
\hline None & $\mathbf{2 6 . 1}$ & 27.3 & - \\
\hline DME & 37.8 & 19.9 & $\mathbf{1 3 . 7}$ \\
\hline OXA & 35.1 & $\mathbf{2 2 . 9}$ & 36.9 \\
\hline GLA & 37.34 & $\mathbf{2 0 . 1 4}$ & 35.4 \\
\hline EDA & 39.1 & $\mathbf{2 8 . 9}$ & $\mathbf{3 0 . 9}$ \\
\hline HMTA & 44.2 & 31.3 & $\mathbf{2 7 . 8 5}$ \\
\hline TEDA & 28.85 & 30.18 & \\
\hline
\end{tabular}

Atomic charge calculations were made by the Bader method [20], in order to elucidate the electronic interactions of the multi-functional agents bonded with the $\mathrm{ZrO}_{2}$ nano-framework and the $\mathrm{NaTi}\left(\mathrm{BH}_{4}\right)_{4}$ cluster, and their impact on the reversibility of the hydride at the interface with $\mathrm{ZrO}_{2}$. The local atomic charges were evaluated from the difference between atomic electron density in the molecular complexes or solid-state configurations and in the respective unbound atomic states. The charges of the major atoms involved in the ligand interactions are given in Table 8, including the Ti counter-ions of the $\mathrm{NaTi}\left(\mathrm{BH}_{4}\right)_{4}$ complexes and the interacting $\mathrm{O}$ or $\mathrm{N}$ and $\mathrm{C}$ atoms of the multi-functional groups. For functionalization with DME and EDA, the functional groups lost electronic charge in their $\mathrm{O}$ or $\mathrm{N}$ atoms and gained electronic charge on their $\mathrm{C}$ atoms upon interacting with $\mathrm{NaTi}\left(\mathrm{BH}_{4}\right)_{4}$ and $\mathrm{ZrO}_{2}$. For functionalization with TEDA, a much larger gain was predicted for the $\mathrm{N}$ electronic charge. The atomic electronic charges of the multi-functional surface agent at the $\mathrm{NaTi}\left(\mathrm{BH}_{4}\right)_{4}-\mathrm{ZrO}_{2}$ interface were smaller than with $\mathrm{NaTi}\left(\mathrm{BH}_{4}\right)_{4}$ or $\mathrm{ZrO}_{2}$ alone, due to simultaneous interactions with both $\mathrm{NaTi}\left(\mathrm{BH}_{4}\right)_{4}$ and $\mathrm{ZrO}_{2}$. The most significant correlation was found for the change in the electronic charge for the interacting surface agent atoms at the $\mathrm{NaTi}\left(\mathrm{BH}_{4}\right)_{4}-\mathrm{ZrO}_{2}$ interface and with $\mathrm{NaTi}\left(\mathrm{BH}_{4}\right)_{4}$ alone. Here, it can be seen that the change in the electronic charge decreased progressively on the $\mathrm{O}$ or $\mathrm{N}$ atom, following the order: DME, EDA, and TEDA. The moderated electronic interactions of EDA and TEDA on $\mathrm{NaTi}\left(\mathrm{BH}_{4}\right)_{4}$ speak to the importance of balanced interactions for increasing $\mathrm{NaTi}\left(\mathrm{BH}_{4}\right)_{4}$ reversibility. 


\section{First Principles and Thermodynamic Modeling}

Table 8: Atomic charges determined by Bader method for bonding interactions of multi-functional surface agents.

\begin{tabular}{|c|c|c|c|c|c|}
\hline $\begin{array}{l}\text { Multi-functional } \\
\text { Surface Agent - } \\
\text { Atomic Charges } \\
\text { by Bader } \\
\text { Method }\end{array}$ & $\begin{array}{c}\text { Functional } \\
\text { Group }\end{array}$ & $\begin{array}{c}\text { Functionalized } \\
\mathrm{NaTi}\left(\mathrm{BH}_{4}\right)_{4} \\
\text { Cluster }\end{array}$ & $\begin{array}{c}\text { Functionalized } \\
\mathrm{ZrO}_{2} \text { Surface }\end{array}$ & $\begin{array}{c}\text { Functionalized } \\
\mathrm{NaTi}\left(\mathrm{BH}_{4}\right)_{4}- \\
\mathrm{ZrO}_{2} \text { Interface }\end{array}$ & $\begin{array}{c}\text { Formation of } \\
\text { Functionalized } \\
\mathrm{NaTi}\left(\mathrm{BH}_{4}\right)_{4}- \\
\mathrm{ZrO}_{2} \text { Interface }\end{array}$ \\
\hline & \multicolumn{4}{|c|}{ Atomic Charge } & $\begin{array}{l}\Delta \text { Atomic } \\
\text { charge }\end{array}$ \\
\hline $\begin{array}{l}\text { Dimethoxyethan } \\
\mathrm{e} \\
(\mathrm{DME})\end{array}$ & & & & & \\
\hline $\mathrm{Ti}$ & - & 1.61 & - & 1.61 & 0.00 \\
\hline $\mathrm{O}$ & -1.54 & -1.49 & -1.48 & -1.45 & 0.04 \\
\hline $\mathrm{C}$ & 0.63 & 0.66 & 0.56 & 0.58 & -0.08 \\
\hline $\begin{array}{l}\text { Ethylenediamin } \\
\text { e } \\
\text { (EDA) }\end{array}$ & & & & & \\
\hline $\mathrm{Ti}$ & - & 1.62 & - & 1.61 & -0.01 \\
\hline $\mathrm{N}$ & -2.90 & -2.77 & -2.77 & -2.69 & 0.09 \\
\hline $\mathrm{C}$ & 0.91 & 0.69 & 0.69 & 0.66 & -0.03 \\
\hline $\begin{array}{l}\text { Triethylene- } \\
\text { diamine } \\
\text { (TEDA) }\end{array}$ & & & & & \\
\hline $\mathrm{Ti}$ & - & 1.62 & - & 1.62 & 0.00 \\
\hline $\mathrm{N}$ & -1.86 & -2.24 & -2.13 & -2.08 & 0.16 \\
\hline $\mathrm{C}$ & 0.64 & 0.72 & 0.67 & 0.68 & -0.04 \\
\hline
\end{tabular}

\subsection{Thermodynamic Assessment of Framework Reactivity with Hydrides}

One important concern with oxide frameworks was the stability in a reducing atmosphere and against reaction with the incorporated hydride during long term dehydrogenation-rehydrogenation cycles. The compatibility studies of candidate materials for nano-frameworks were evaluated by both thermodynamic calculation and experimental testing. Thermodynamic calculations were made with HSC Chemistry software [21] to assess the relative favorability of candidate oxide: $\mathrm{SiO}_{2}, \mathrm{Al}_{2} \mathrm{O}_{3}$, and $\mathrm{ZrO}_{2}$, reduction reactions in a temperature range of 100 to $300{ }^{\circ} \mathrm{C}$ under 1 bar $\mathrm{H}_{2}$ pressure (See Appendix Table 18 and Table 19). The most favorable reactions were identified through a combination of Gibbs minimization equilibrium and thermochemical reaction calculations with selected solid and gas species. These predictions represent ideal chemical phase equilibria for bulk phases. While these assessments provided guidance in the selection of oxide materials for the experimental compatibility studies, they do not account for size or surface energy contributions to 


\section{First Principles and Thermodynamic Modeling}

nano-scale material reactivity. They represent an upper bound for the most favorable reactions under ideal, equilibrium conditions.

$\mathrm{SiO}_{2}+2 \mathrm{H}_{2}=\mathrm{Si}+2 \mathrm{H}_{2} \mathrm{O}$

$1 /{ }_{2} \mathrm{Al}_{2} \mathrm{O}_{3}+{ }^{3} /{ }_{2} \mathrm{H}_{2}=\mathrm{Al}+1.5 \mathrm{H}_{2} \mathrm{O}$

$\mathrm{ZrO}_{2}+2 \mathrm{H}_{2}=\mathrm{Zr}+2 \mathrm{H}_{2} \mathrm{O}$

The reduction reactions in equations (7-9) were all unfavorably endothermic in value, increasing with the order of oxides: $\mathrm{SiO}_{2}<\mathrm{Al}_{2} \mathrm{O}_{3}<\mathrm{ZrO}_{2}$. Thus, the reduction of $\mathrm{ZrO}_{2}$ was predicted to require the greatest enthalpy investment. The thermodynamic calculations showed that it was very favorable for all three oxides, $\mathrm{SiO}_{2}, \mathrm{Al}_{2} \mathrm{O}_{3}$, and $\mathrm{ZrO}_{2}$, to react with $\mathrm{LiBH}_{4}$, forming lithium metaborate, lithium silicate, or lithium aluminate and corresponding metal borides, as given in reaction equations (10-13), respectively.

$$
\begin{aligned}
& \mathrm{LiBH}_{4}+\mathrm{SiO}_{2}=\mathrm{LiBO}_{2}+\mathrm{Si}+2 \mathrm{H}_{2} \\
& 4 \mathrm{LiBH}_{4}+3 \mathrm{SiO}_{2}=2 \mathrm{Li}_{2} \mathrm{SiO}_{3}+\mathrm{SiB}_{4}+8 \mathrm{H}_{2} \\
& 3 \mathrm{LiBH}_{4}+2 \mathrm{Al}_{2} \mathrm{O}_{3}=3 \mathrm{LiAlO}_{2}+\mathrm{AlB}_{2}+\mathrm{B}+6 \mathrm{H}_{2} \\
& 5 \mathrm{LiBH}_{4}+2 \mathrm{ZrO}_{2}=\mathrm{LiBO}_{2}+2 \mathrm{Li}_{2} \mathrm{O}+2 \mathrm{ZrB}_{2}+10 \mathrm{H}_{2}
\end{aligned}
$$

Since $\mathrm{Al}_{2} \mathrm{O}_{3}$ and $\mathrm{ZrO}_{2}$ are very stable oxides, these reactions may be kinetically hindered at temperatures below $300{ }^{\circ} \mathrm{C}$. 


\section{Experimental Synthesis and Characterization of Nano-Framework}

\section{Experimental Synthesis and Characterization of Nano-Framework}

Several high surface oxides and $\mathrm{C}$ nano framework materials were designed and synthesized for reactivity tests as well as for hydride incorporation. The oxide aerogels were primarily prepared using sol - gel methods, following by atmospheric drying to obtain high surface area nano-framework materials. The aerogel was then calcined at $400{ }^{\circ} \mathrm{C}-550{ }^{\circ} \mathrm{C}$ to obtain a stable oxide structure. The effect of calcination conditions on aerogel surface area was investigated with yttria stablized zirconia (YSZ) aerogel. Calcination at $550{ }^{\circ} \mathrm{C}$ reduced its surface area by $74 \%$, while calcinations at $400{ }^{\circ} \mathrm{C}$ only reduced by $59 \%$. YSZ was further catalyzed with platinum catalyst using incipient wetness method. C aerogels were prepared through pyrolysis of two different polymer precursors in an attempt to produce different functionalized $\mathrm{C}$ surfaces. One polymer precursor was polyimide (PI), producing $\mathrm{N}$-containing $\mathrm{C}$ surface. Another was phenolic polymer (PF), generating O-containing $\mathrm{C}$ surfaces. The aerogels were characterized by XRD, TGA and $\mathrm{N}_{2}$ porosimetry, etc.

\subsection{Synthesis of Alumina and Silica Zerogels}

Several high surface area metal oxide and mixed-metal oxide materials (alumina, silica, and alumininosilicates) were designed and synthesized at UTRC through traditional sol-gel approaches to form xerogels using atmospheric pressure and room temperature drying. These oxides were further characterized via BET nitrogen porosimetry. The pore sizes and specific surface areas were as targeted, being $5.4 \mathrm{~nm}$ and $267 \mathrm{~m}^{2} / \mathrm{g}$ for alumina, and $6.6 \mathrm{~nm}$ and $383 \mathrm{~m}^{2} / \mathrm{g}$ for silica. Another technique for preparing these structures was investigated utilizing a lyophilizer (well-controlled freeze dryer) to bypass the liquid-vapor phase line and associated high surface tension to dry the material via sublimation. The initial synthesis of a silica cryogel resulted in an average pore size of $17.97 \mathrm{~nm}$, significantly larger that the circa $5 \mathrm{~nm}$ pores achieved with the xerogels, and a specific surface area of $327 \mathrm{~m}^{2} / \mathrm{g}$. Variation in the processing conditions resulted in smaller pore sizes and comparable specific surface areas of approximately $5 \mathrm{~nm}$ and $>300 \mathrm{~m}^{2} / \mathrm{g}$.

\subsection{Zirconia Aerogel Synthesis and Calcination}

After conducting a number of small batch trials to refine the synthesis methodology for yttriastabilized zirconia (YSZ) aerogel, Aspen Aerogels produced a total of $100 \mathrm{~g}$ of material, $15 \mathrm{~g}$ of which was calcined under the standard conditions of $550{ }^{\circ} \mathrm{C}$ for 1 hour and is shown in Figure 6 as being in powdered rather than monolithic form. The remainder was not calcined, so that UTRC could conduct additional studies to alter the aerogel characteristics, primarily to increase the specific surface area. The XRD pattern for the material is shown in Figure 7, indicating that the sample consists of crystalline tetragonal zirconium yttrium oxide with $\mathrm{a}=\mathrm{b}=3.63 \AA, \mathrm{c}=5.13 \AA$ and crystallite size $=66 \AA$.

A temperature-gas processing vessel was constructed for the calcination studies at UTRC which could reach moderately high temperatures with an existing furnace $\left(450{ }^{\circ} \mathrm{C}\right)$, which provided a hermetic seal from atmospheric exposure and could be transferred through the glove box antechamber. One of the calcination trials was conducted at $400{ }^{\circ} \mathrm{C}$ for 6 hours in flowing air, followed by a cool-down period under active vacuum, using a diaphragm pump for cleanliness. Results for the surface area and pore size measured with BET porosimetry are given in Table 9. Calcination significantly reduced the surface area, but the alternative temperature / time procedure increased the post-calcined surface area by $60 \%$. 


\section{Experimental Synthesis and Characterization of Nano-Framework}

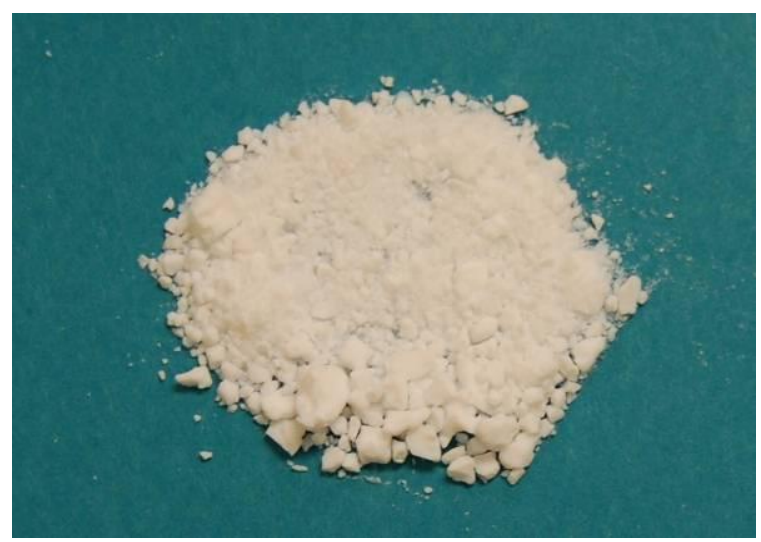

Figure 6: Yttria-stabilized zirconia calcined at $550{ }^{\circ} \mathrm{C}$ for 1 hour.

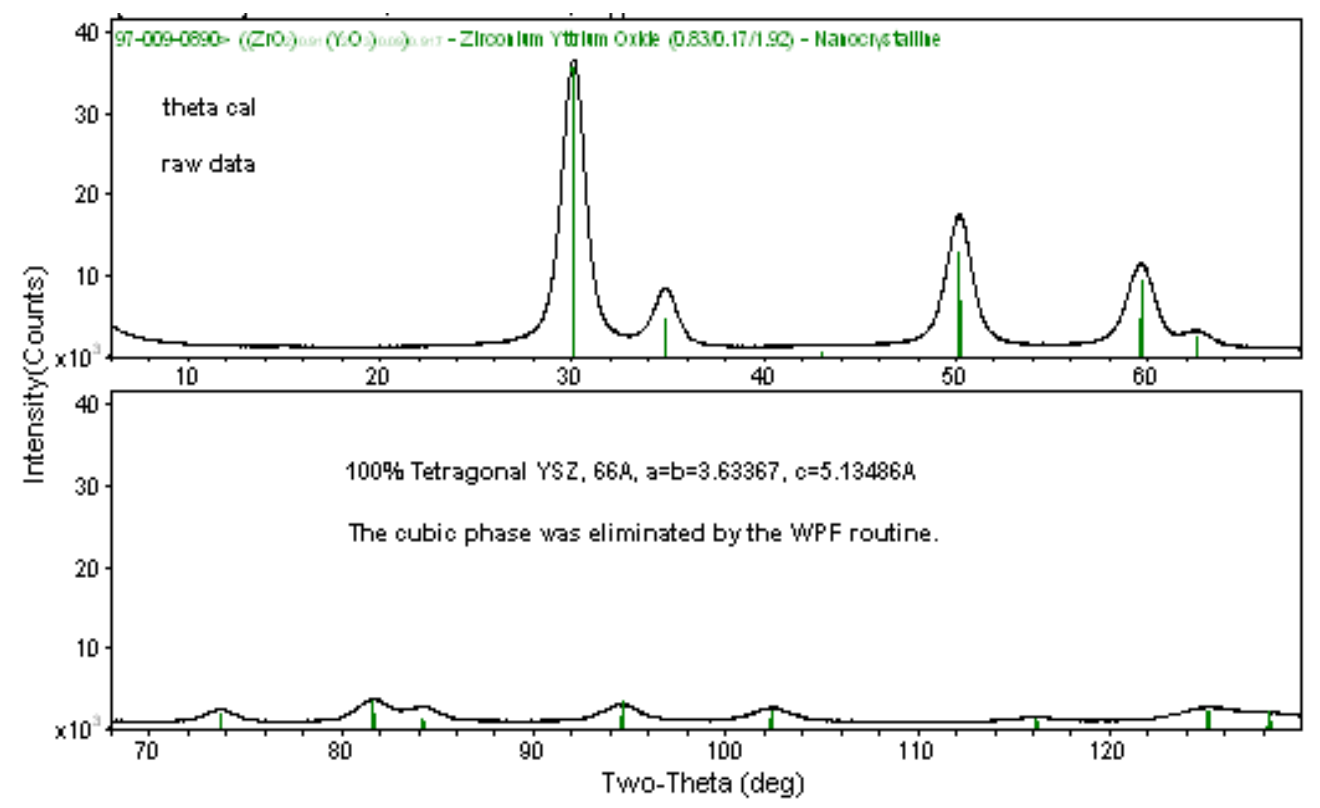

Figure 7: XRD pattern of calcined $\left(550^{\circ} \mathrm{C}\right.$ for 1 hour) zirconia aerogel sample.

Table 9: Size scale properties of zirconia aerogel for various processing.

\begin{tabular}{|c|c|c|}
\hline Processing & $\begin{array}{c}\text { Surface area, } \\
{\left[\mathbf{m}^{2} / \mathbf{g}\right]}\end{array}$ & Average Pore size, $[\AA]$ \\
\hline Uncalcined & 538 & 11.8 \\
\hline $550^{\circ} \mathrm{C} / 1$ hour calcination & 138 & 11.7 \\
\hline $400^{\circ} \mathrm{C} / 6$ hours calcination & 221 & 15.2 \\
\hline
\end{tabular}

TGA testing was performed on an un-calcined sample, as shown in Figure 8, with a ramp up to 400 ${ }^{\circ} \mathrm{C}$ in flowing air (with an hour hold), followed by cool-down and re-heat in flowing nitrogen. There was a $2 \%$ increase in weight as the equipment cooled down to room temperature, which may be 


\section{Experimental Synthesis and Characterization of Nano-Framework}

attributed to a leak in the TGA system. Since the final weight after increasing the temperature to $1000{ }^{\circ} \mathrm{C}$ was similar to the weight after an 1 hour hold at $400{ }^{\circ} \mathrm{C}$, the initial conclusion was made that the $400{ }^{\circ} \mathrm{C}$ calcination stage appeared to be sufficient to remove residual hydroxyl groups.

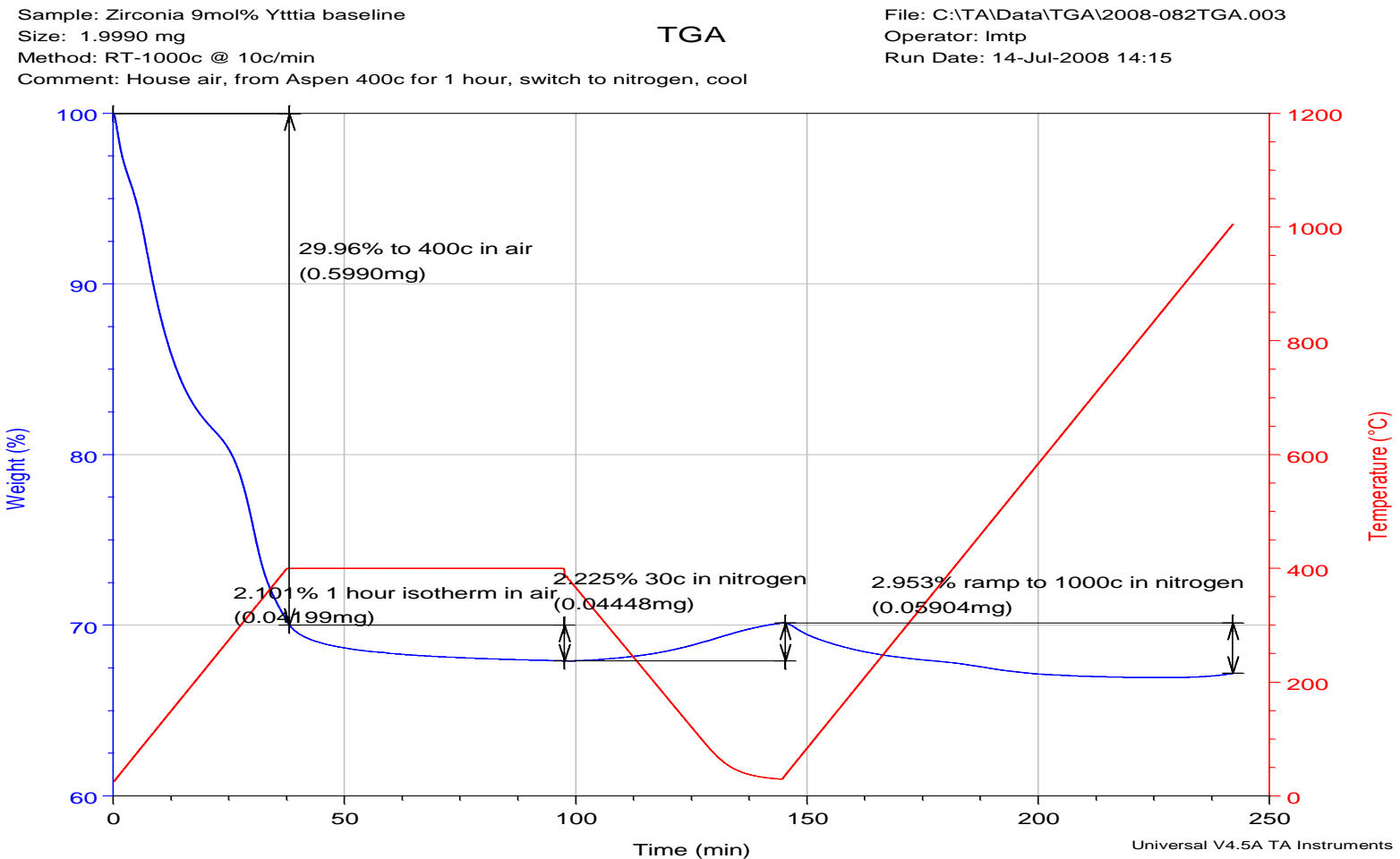

Figure 8: TGA testing of un-calcined yttria-stabilized zirconia aerogel.

\subsection{Catalyzation of YSZ aerogel}

The attempt of catalyzing YSZ with Pt using the method in reference [22] failed to produce highly dispersed Pt catalyst due to the difficulties in filtering the fine YSZ particles. The YSZ aerogel was subsequently catalyzed using a modified incipient wetness method. Two different YSZ supports were catalyzed using $\mathrm{Pt}\left(\mathrm{NH}_{3}\right)_{4}\left(\mathrm{NO}_{3}\right)_{2}$ as precursor. Pt-loaded supports were calcined at $400{ }^{\circ} \mathrm{C}$ for 4 hours in air to decompose $\mathrm{Pt}$ compound, followed by a reduction at $300{ }^{\circ} \mathrm{C}$. The properties of these samples are listed in Table 10.

\subsection{Carbon (C) Aerogels}

Two $\mathrm{C}$ aerogels were prepared through pyrolysis of polyimide and phenolic polymers by Aspen Aerogels, designated as $\mathrm{C}(\mathrm{PI})$ and $\mathrm{C}(\mathrm{PF})$, respectively. These two different precursor routes were selected to produce desired non-C elements. The monolithic aerogels were cut into $1 \mathrm{~mm}$ thick wafers for hydride incorporation. The size scale and elemental analysis results are shown in Table 9. The $\mathrm{C}$ aerogel derived from polyimide contains $9.89 \% \mathrm{~N}$, while the phenolic polymer derived C aerogel contains only $0.64 \% \mathrm{~N}$. Oxygen cannot be measured with elemental analysis technique, but it can be estimated by materials balance. 


\section{Experimental Synthesis and Characterization of Nano-Framework}

Table 10: Properties of Pt-catalyzed YSZ

\begin{tabular}{|c|c|c|c|c|}
\hline $\begin{array}{c}\text { NFS Material } \\
\text { Treatment in Air } \\
\text { (temperature } / \text { time) }\end{array}$ & Pt wt\% & $\begin{array}{c}\text { S.A. } \\
\mathrm{m}^{2} / \mathrm{g}\end{array}$ & $\begin{array}{c}\text { Avg. Pore } \\
\mathrm{nm}\end{array}$ & $\begin{array}{c}\text { Pore volume } \\
\text { cc/g }\end{array}$ \\
\hline $\begin{array}{c}\text { YSZ aerogel }(9 \mathrm{~mol} \%) \\
550^{\circ} \mathrm{C} / 1 \text { hour }\end{array}$ & - & 140 & 11.8 & 0.69 \\
\hline $\begin{array}{c}\text { YSZ aerogel }(9 \mathrm{~mol} \%) \\
400^{\circ} \mathrm{C} / 6 \text { hours }\end{array}$ & - & 204 & 11.0 & 0.86 \\
\hline $\begin{array}{c}\text { Pt/YSZ aerogel }(9 \mathrm{~mol} \%) \\
550^{\circ} \mathrm{C} / 1 \text { hour }\end{array}$ & 0.51 & 130 & 18 & 0.69 \\
\hline $\begin{array}{c}\text { YSZ aerogel }(9 \mathrm{~mol} \%) \\
400{ }^{\circ} \mathrm{C} / 6 \text { hours }\end{array}$ & 0.71 & 175 & 19.0 & 0.98 \\
\hline
\end{tabular}

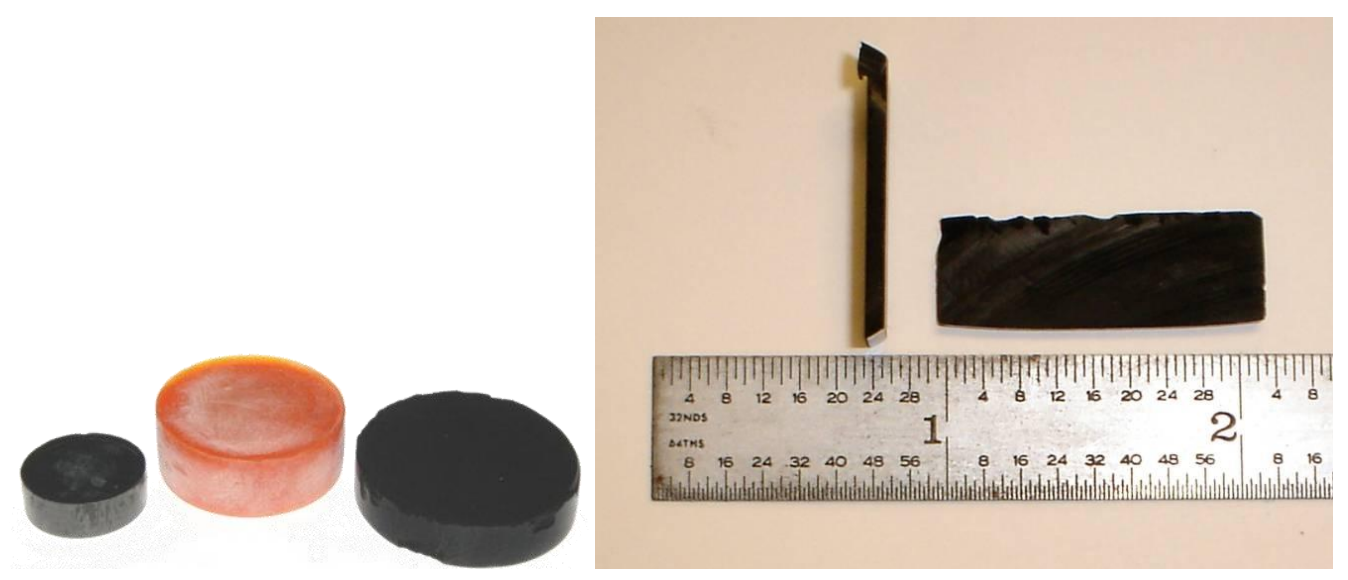

Figure 9: Monolithic $\mathrm{C}$ aerogels prepared by carbonizing polymer.

Table 11: Pore sizes, surface areas and elemental analysis of $\mathrm{C}$ aerogels

\begin{tabular}{|c|c|c|c|c|c|}
\hline NFS Material & $\begin{array}{l}\text { S.A. } \\
\mathrm{m}^{2} / \mathrm{g}\end{array}$ & $\begin{array}{c}\text { Average } \\
\text { Pore size } \\
\text { nm } \\
\end{array}$ & $\begin{array}{c}\text { Pore } \\
\text { volume } \\
\text { cc/g }\end{array}$ & $\begin{array}{l}\text { Density } \\
\text { g/cc }\end{array}$ & $\begin{array}{c}\text { Elemental } \\
\text { Analysis }\end{array}$ \\
\hline $\begin{array}{l}\text { Carbon aerogel from } \\
\text { polyimide pyrolysis } \\
-\mathrm{C}(\mathrm{PI})\end{array}$ & 582.8 & 24.8 & 3.67 & 0.26 & $\begin{array}{l}\mathrm{C}=86.31 \% \\
\mathrm{H}=0.95 \% \\
\mathrm{~N}=9.89 \%\end{array}$ \\
\hline $\begin{array}{l}\text { Carbon aerogel from } \\
\text { phenolic pyrolysis - } \\
\mathrm{C}(\mathrm{PF})\end{array}$ & 818.4 & 16.5 & 3.22 & 0.26 & $\begin{array}{l}\mathrm{C}=95.43 \% \\
\mathrm{H}=0.83 \% \\
\mathrm{~N}=0.64 \%\end{array}$ \\
\hline
\end{tabular}




\section{Screening of Nano-Framework Reactivity with Borohydrides}

\section{Screening of Nano-Framework Reactivity with Borohydrides}

Thermodynamic assessment of reactivity of oxide nano-framework with $\mathrm{LiBH}_{4}$, described in Section 3.6, showed very favorable reactions of all three oxides, $\mathrm{SiO}_{2}, \mathrm{Al}_{2} \mathrm{O}_{3}$, and $\mathrm{ZrO}_{2}$ with $\mathrm{LiBH}_{4}$, forming lithium metaborate, lithium silicate, or lithium aluminate and corresponding metal borides. In this section, experimental investigation of nano-framework reactivity with borohydrides was carried out to verify reactions between nano-framework material and borohydrides, including $\mathrm{LiBH}_{4}$ and $\mathrm{Ca}\left(\mathrm{BH}_{4}\right)_{2}$. The impact of nano-framework materials on $\mathrm{H}_{2}$ desorption and absorption properties of $\mathrm{Ca}\left(\mathrm{BH}_{4}\right)_{2}$ was also investigated. $\mathrm{ZrO}_{2}$ and phenolic polymer (PI) derived $\mathrm{C}$ aerogel materials were identified as most stable nano-framework materials against borohydrides. This observation verified the atomic modeling prediction that $\mathrm{ZrO} 2$ (101) surface is least likely to interaction with borohydride to form undesired side reaction products. $\mathrm{C}$ aerogels and $\mathrm{Pt} / \mathrm{YSZ}$ also showed enhancement in $\mathrm{H}_{2}$ desorption kinetics in SPEX milled mixtures with $\mathrm{Ca}\left(\mathrm{BH}_{4}\right)_{2}$.

\subsection{Nano-Crystalline Oxide Reactivity with $\mathrm{LiBH}_{4}$}

Aerogels and nano-crystalline oxides were first used to evaluate the reactivity of nano-frameworks with borohydrides. These materials closely mimic the average wall thickness and pore dimensions in oxide nano-frameworks that were to be developed for hydride containment in future studies. A silica aerogel with a BET surface area of $551 \mathrm{~m}^{2} / \mathrm{g}$ and average pore size of $169 \AA$ was obtained from Cabot. The silica aerogel was shown to be amorphous by XRD. Alumina was prepared by acid hydrolysis of aluminum tri-sec-butoxide at UTRC. The $\mathrm{Al}_{2} \mathrm{O}_{3}$ powder was calcined under at $575{ }^{\circ} \mathrm{C}$ for one hour. The average $\mathrm{Al}_{2} \mathrm{O}_{3}$ crystallite size was $49 \AA$ by XRD peak broadening. The small particles associated through their highest energy surfaces to form aggregates. The aggregated $\mathrm{Al}_{2} \mathrm{O}_{3}$ BET surface area was $267 \mathrm{~m}^{2} / \mathrm{g}$ and average pore size was $54 \AA$. Zirconia was prepared via precipitation from solution [22]. The material was calcined at $400{ }^{\circ} \mathrm{C}$ for 4 hours. $\mathrm{The}^{2} \mathrm{ZrO}_{2}$ had an average crystallite size of $55 \AA$. The aggregated $\mathrm{ZrO}_{2}$ BET surface area was $134 \mathrm{~m}^{2} / \mathrm{g}$ and average pore size was $33 \AA$. The oxide surface areas on a skeletal volume basis were: $\mathrm{SiO}_{2} 1466 \mathrm{~m}^{2} / \mathrm{cm}^{3}$, $\mathrm{Al}_{2} \mathrm{O}_{3} 1060 \mathrm{~m}^{2} / \mathrm{cm}^{3}$ and $\mathrm{ZrO}_{2} 750 \mathrm{~m}^{2} / \mathrm{cm}^{3}$. The well known hydride, $\mathrm{LiBH}_{4}(>90 \%$, Sigma-Aldrich) was selected for this survey to enable benchmarking with previous results reported in the literature $[11,23]$.

The experimental tests were carried out to obtain direct evidence of the side-products that can form from the reaction of $\mathrm{LiBH}_{4}$ with the nano-scale oxides, in comparison with the thermodynamic predictions. The SPEX mill mixing approach enabled quick screening of oxide- $\mathrm{LiBH}_{4}$ compatibility, but did not necessarily provide a fair test of the benefits of oxide nano-framework confinement. The reactivity of these intimately mixed, high surface energy nano-materials can be expected to be enhanced relative to mixtures of coarser micro- and higher scale materials. Larger materials with inherently increased diffusion distances and decreased surface area/volume ratios may be even further from thermodynamic equilibrium, especially at lower temperatures. The reactivity screening was primarily conducted with TGA-MS. The TGA-MS of $\mathrm{LiBH}_{4}$ alone showed the $\mathrm{H}_{2}$ release started at $280{ }^{\circ} \mathrm{C}$, with two minor peaks at approximately 294 and $365^{\circ} \mathrm{C}$ and a major peak at $450{ }^{\circ} \mathrm{C}$, as shown in Figure 10. In the mixture of $\mathrm{LiBH}_{4}$ and $\mathrm{SiO}_{2}$, the majority of the $\mathrm{H}_{2}$ release was in the $280-350{ }^{\circ} \mathrm{C}$ temperature range, eliminating the significant $\mathrm{H}_{2}$ peak at $450{ }^{\circ} \mathrm{C}$. This indicated that either $\mathrm{SiO}_{2}$ reacted with $\mathrm{LiBH}_{4}$ or catalyzed the $\mathrm{LiBH}_{4} \mathrm{H}_{2}$ desorption [11]. Similar to the $\mathrm{LiBH}_{4}-\mathrm{SiO}_{2}$ mixture, the $\mathrm{LiBH}_{4}-\mathrm{Al}_{2} \mathrm{O}_{3}$ mixture showed a major $\mathrm{H}_{2}$ evolution peak at approximately $350{ }^{\circ} \mathrm{C}$. The TGA-MS of the $\mathrm{LiBH}_{4}-\mathrm{ZrO}_{2}$ mixture, however, showed a minor hydrogen peak at $360-380{ }^{\circ} \mathrm{C}$ and a major 


\section{Screening of Nano-Framework Reactivity with Borohydrides}

peak at $410-470{ }^{\circ} \mathrm{C}$, close to that of $\mathrm{LiBH}_{4}$. The $\mathrm{ZrO}_{2}$ did not appear to react with $\mathrm{LiBH}_{4}$ and only weakly catalyzed the shift of the dehydrogenation peak to lower temperatures.

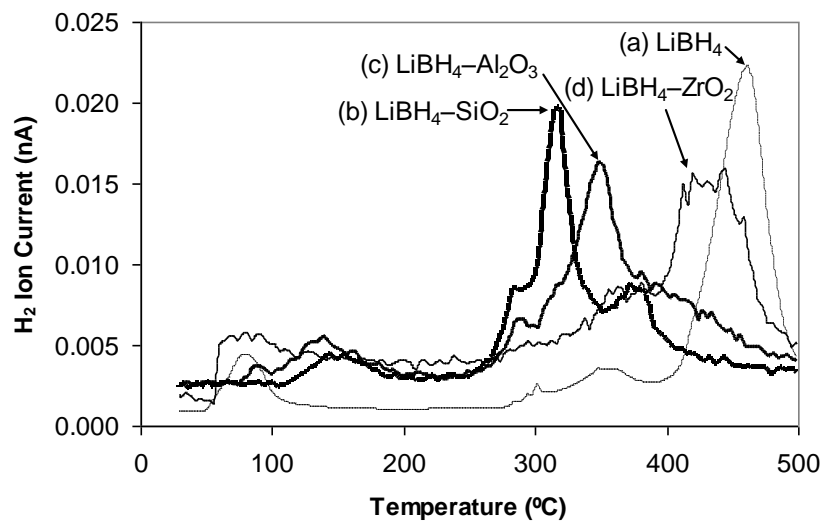

Figure 10: Thermal gravimetric analysis-mass spectrometry of $\mathrm{LiBH}_{4}$ mixtures with $\mathrm{SiO}_{2}, \mathrm{Al}_{2} \mathrm{O}_{3}$ and $\mathrm{ZrO}_{2}$ and neat $\mathrm{LiBH}_{4}$.

In order to further examine reactivity, the $\mathrm{LiBH}_{4}-\mathrm{SiO}_{2}, \mathrm{LiBH}_{4}-\mathrm{Al}_{2} \mathrm{O}_{3}$ and $\mathrm{LiBH}_{4}-\mathrm{ZrO}_{2}$ mixtures were charged at $290{ }^{\circ} \mathrm{C}$ and 190 bar $\mathrm{H}_{2}$, followed by discharging at $290{ }^{\circ} \mathrm{C}$ and $1 \mathrm{bar}_{2}$. X-ray diffraction analyses were conducted to identify any crystalline reaction products after the charge-discharge cycle. Figure 11 shows the XRD analysis of the as-milled and charge-discharge cycled $\mathrm{LiBH}_{4}-\mathrm{SiO}_{2}$ mixture. The predominant product was lithium catena-silicate, $\mathrm{Li}_{2} \mathrm{SiO}_{3}$, similar to the thermodynamically favorable lithium silicate product given in reaction equation (11), along with a small amount of boric acid, $\mathrm{H}_{3} \mathrm{BO}_{3}$. The formation of stable $\mathrm{Li}_{2} \mathrm{SiO}_{3}$ and $\mathrm{H}_{3} \mathrm{BO}_{3}$ phases during the charge-discharge cycle indicated that the $\mathrm{H}$ storage capacity was lost since $\mathrm{LiBH}_{4}$ could not be reformed. The destabilization of $\mathrm{LiBH}_{4}$ dehydrogenation by reaction product formation is a likely explanation for the significant irreversible $\mathrm{LiBH}_{4}$ dehydrogenation by $\mathrm{SiO}_{2}$ powder [11]. The formation of the lithium borate, $\mathrm{Li}_{3} \mathrm{BO}_{3}$, which is similar in stability, was experimentally observed during rehydrogenation of $\mathrm{LiBH}_{4}$ catalyzed with $\mathrm{TiO}_{2}$ and increased in amount with repeated cycling, progressively decreasing the $\mathrm{H}$ storage capacity [25]. In the $\mathrm{LiBH}_{4}-\mathrm{Al}_{2} \mathrm{O}_{3}$ system, $\mathrm{LiBH}_{4}$ was present as the main crystalline component detected by XRD as shown in the lower curve (a) in Figure 11 for the sample after cycling. A small amount of $\mathrm{H}_{3} \mathrm{BO}_{3}$ and lithium metaborate, $\mathrm{LiBO}_{2}$, was formed, indicating a slight interaction occurred at temperatures up to $290{ }^{\circ} \mathrm{C}$. In the $\mathrm{LiBH}_{4}-\mathrm{ZrO}_{2}$ system, $\mathrm{LiBH}_{4}$ and $\mathrm{ZrO}_{2}$ were the only crystalline phases present after charge and discharge. $\mathrm{No} \mathrm{H}_{3} \mathrm{BO}_{3}$ or other reaction product was detected, as shown by the upper curve (b) in Figure 12. This suggested that $\mathrm{LiBH}_{4}$ was compatible with the $\mathrm{ZrO}_{2}$ nano-crystallite material. Based on the experimental tests, the order of compatibility was: $\mathrm{ZrO}_{2}>\mathrm{Al}_{2} \mathrm{O}_{3}>\mathrm{SiO}_{2}$. 


\section{Screening of Nano-Framework Reactivity with Borohydrides}

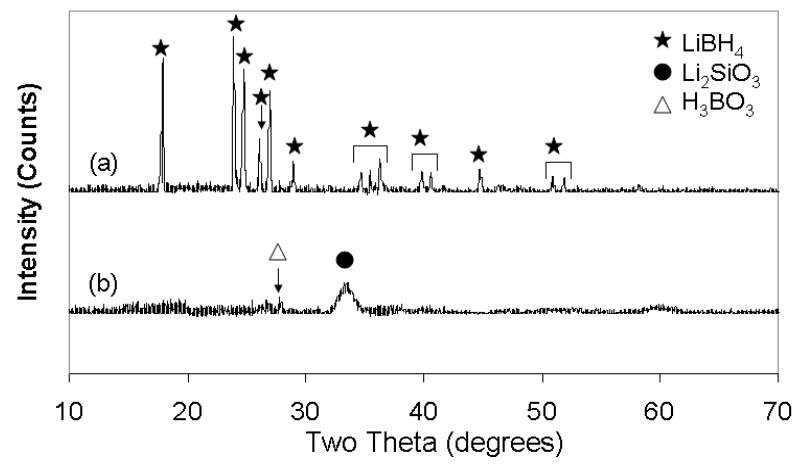

Figure 11: X-ray diffraction of the $\mathrm{LiBH}_{4}-\mathrm{SiO}_{2}$ mixtures, (a) as milled and (b) charged at $290{ }^{\circ} \mathrm{C}$ and 190 bar of $\mathrm{H}_{2}$, and discharged at $290^{\circ} \mathrm{C}$ and 1 bar of $\mathrm{H}_{2}$.

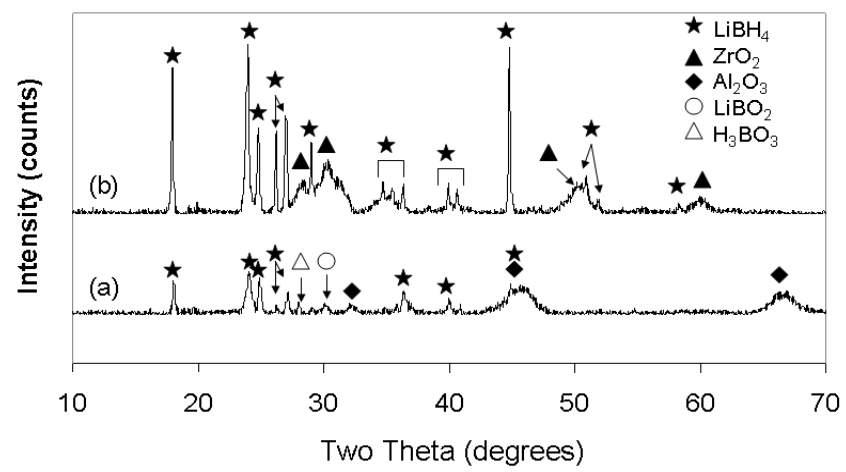

Figure 12: X-ray diffraction of the (a) $\mathrm{LiBH}_{4}-\mathrm{Al}_{2} \mathrm{O}_{3}$ and (b) $\mathrm{LiBH}_{4}-\mathrm{ZrO}_{2}$ mixtures after being charged at $290{ }^{\circ} \mathrm{C}$ and 190 bar of $\mathrm{H}_{2}$, and discharged at $290{ }^{\circ} \mathrm{C}$ and 1 bar of $\mathrm{H}_{2}$.

\subsection{Selection of Oxide for Nano-framework Development}

Strong interfacial interactions of the fully charged hydride or the dehydrogenation products with the oxide nano-frameworks may be harnessed to tune hydride reversibility or kinetics. However, in order to repeatedly cycle $\mathrm{H}_{2}$ discharging and recharging without significant loss of $\mathrm{H}$ storage capacity, the nano-framework candidate for hydride containment must be stable in highly reducing atmospheres and chemically resistant to hydride degradative attack. Based on the combined experimental, thermodynamic and atomic modeling assessments, the nano-crystalline $\mathrm{ZrO}_{2}$ was selected to be the most compatible oxide with $\mathrm{LiBH}_{4}$. No reactions were observed for $\mathrm{LiBH}_{4}$ with $\mathrm{ZrO}_{2}$ cycling at temperatures up to $290{ }^{\circ} \mathrm{C}$ by experimentation and lower adsorption interactions were predicted by atomic modeling, although their reaction was predicted to be favorable by equilibrium thermodynamic evaluation. The nano-crystalline $\mathrm{Al}_{2} \mathrm{O}_{3}$ was less compatible with $\mathrm{LiBH}_{4}$ than $\mathrm{ZrO}_{2}$, which could lead to potential stability issues in longer term $\mathrm{H}$ storage cycling. The $\mathrm{SiO}_{2}$ aerogel was not compatible with $\mathrm{LiBH}_{4}$ at temperatures higher that $250{ }^{\circ} \mathrm{C}$. Here, our findings of a $\mathrm{LiBH}_{4}-\mathrm{SiO}_{2}$ destabilization reaction served to explain previously reported results [11]. $\mathrm{LiBH}_{4}$ reacts with $\mathrm{SiO}_{2}$, forming $\mathrm{Li}_{2} \mathrm{SiO}_{3}$. This resulted in the loss of $\mathrm{LiBH}_{4} \mathrm{H}$ storage capability. 


\section{Screening of Nano-Framework Reactivity with Borohydrides}

\subsection{Nano-Framework Reactivity with $\mathrm{Ca}\left(\mathrm{BH}_{4}\right)_{2}$}

The experimental compatibility studies screened for irreversible, degrading reactions between the hydride and nano-framework. The as-received Aldrich $\mathrm{Ca}\left(\mathrm{BH}_{4}\right)_{2}$ in tetrahydrofuran (THF) was first analyzed using XRD, TGA-MS and DSC. Figure 13 shows the XRD of this material. It contained mostly a high temperature phase, with a small amount of the low temperature phase present. No $\mathrm{Ca}\left(\mathrm{BH}_{4}\right)_{2} * 2 \mathrm{THF}$ material was detected by XRD. TGA-MS analyses (Figure 14) showed that the majority of $\mathrm{H}_{2}$ gas evolved at circa $388^{\circ} \mathrm{C}$. This $\mathrm{H}_{2}$ desorption temperature was in agreement with the DSC endothermic peak at $385^{\circ} \mathrm{C}$ (Figure 15). These results were consistent with the data reported by SNL [26]. Small amounts of organic compounds were detected in the out - gas by TGA-MS. These organic gaseous species were released at two temperature regions: $75-225^{\circ} \mathrm{C}$ and $350-410{ }^{\circ} \mathrm{C}$. Based on the mass fragments, THF was identified as the species evolved in the low temperature region and $\mathrm{C}_{4} \mathrm{H}_{8}$ in the high temperature. This observation indicated that the majority of the solvent ligand in $\mathrm{Ca}\left(\mathrm{BH}_{2}\right)_{2}$ *2THF can removed, but a small amount of THF remained tightly bound to $\mathrm{Ca}\left(\mathrm{BH}_{4}\right)_{2}$, and did not volatilize until $\mathrm{Ca}\left(\mathrm{BH}_{4}\right)_{2}$ started to desorb $\mathrm{H}_{2}$. Based on the organics evolved at temperatures of $350-410{ }^{\circ} \mathrm{C}$, the THF ligand decomposed at this temperature, forming $\mathrm{C}_{4} \mathrm{H}_{8}$ as a gas product. This decomposition broke $\mathrm{C}-\mathrm{O}$ bonds, leaving oxygen in the hydride material. TGA-MS analysis was also conducted for two $\mathrm{Ca}\left(\mathrm{BH}_{4}\right)_{2}$ samples prepared at UTRC by heat treatment of $\mathrm{Ca}\left(\mathrm{BH}_{2}\right)_{2} * 2 \mathrm{THF}$ at $160{ }^{\circ} \mathrm{C}$ for 1 hour in vacuum and at $200{ }^{\circ} \mathrm{C}$ for 20 hours in vacuum. Similar to the $\mathrm{Ca}\left(\mathrm{BH}_{4}\right)_{2}$ from Aldrich, these two samples also contained a small amount of THF.

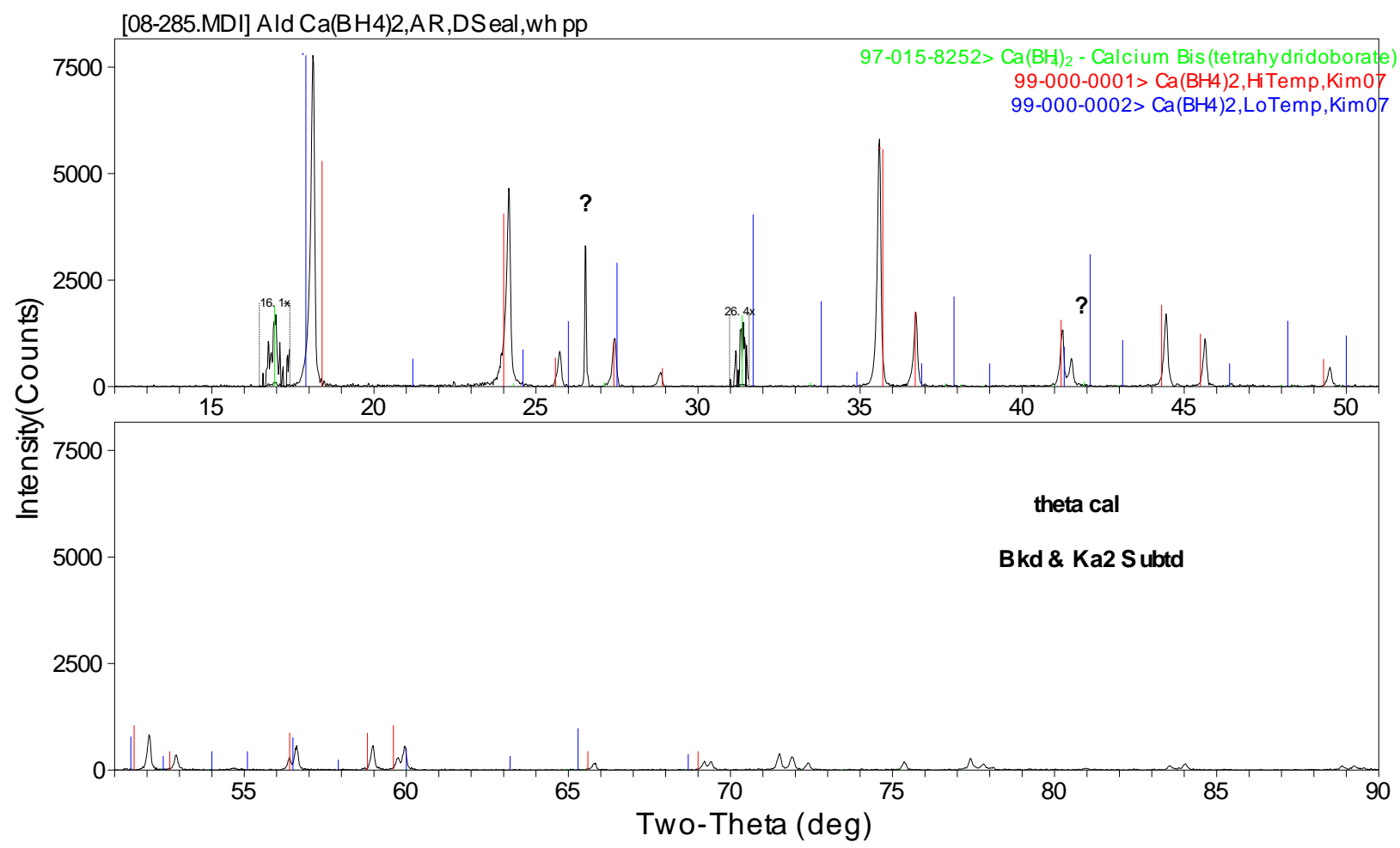

Figure 13: XRD of the as-received $\mathrm{Ca}\left(\mathrm{BH}_{4}\right)_{2}$ from Aldrich. 
Screening of Nano-Framework Reactivity with Borohydrides

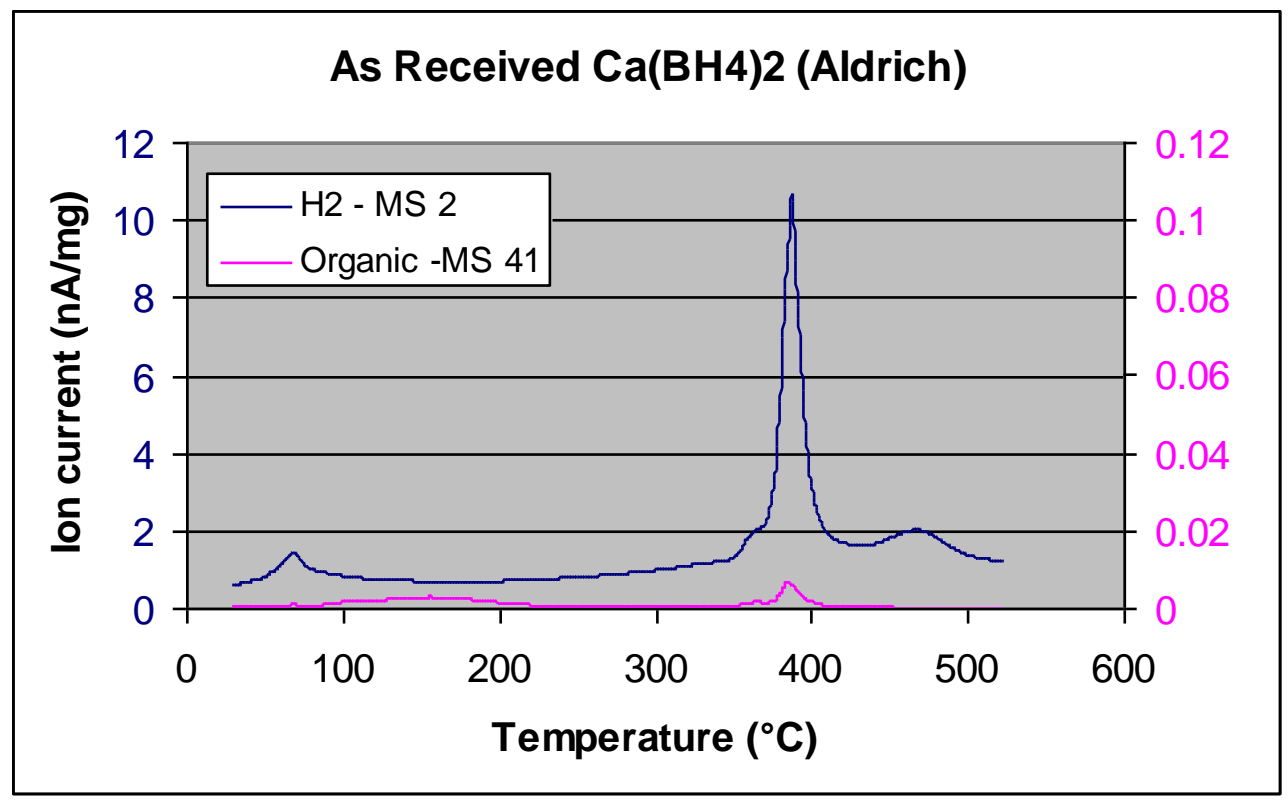

Figure 14: TGA-MS of as received $\mathrm{Ca}\left(\mathrm{BH}_{4}\right)_{2}$ from Aldrich.

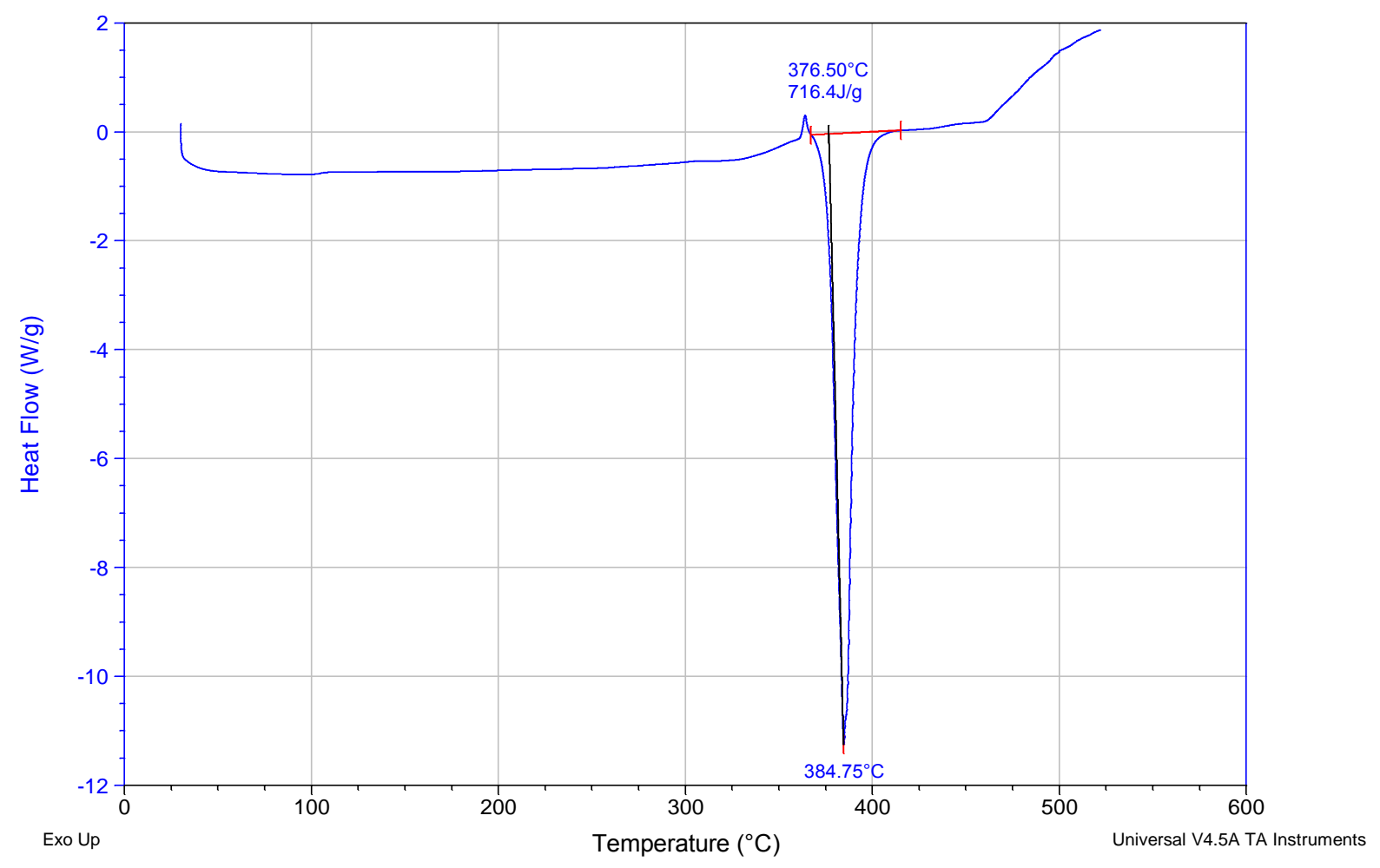

Figure 15: DSC of as received $\mathrm{Ca}\left(\mathrm{BH}_{4}\right)_{2}$ from Aldrich. 


\section{Screening of Nano-Framework Reactivity with Borohydrides}

The reactivity of $\mathrm{Ca}\left(\mathrm{BH}_{4}\right)_{2}$ with $\mathrm{SiO}_{2}$ and $\mathrm{Al}_{2} \mathrm{O}_{3}$ was evaluated by TGA-MS and DSC. The samples were prepared by ball milling $\mathrm{Ca}\left(\mathrm{BH}_{4}\right)_{2}$ with $\mathrm{SiO}_{2}$ and $\mathrm{Al}_{2} \mathrm{O}_{3}$ respectively at 1:1 mole ratio. Figure 16 shows the TGA-MS and DSC of the mixture of $\mathrm{Ca}\left(\mathrm{BH}_{4}\right)_{2}$ and $\mathrm{SiO}_{2}$. The TGA-MS analysis indicated a broad hydrogen evolution temperature range of $200{ }^{\circ} \mathrm{C}$ to $>525^{\circ} \mathrm{C}$, with a peak at $390{ }^{\circ} \mathrm{C}$. The DSC also shows similar reaction features, with a broad endothermic event in the range of $220-520^{\circ} \mathrm{C}$ and an endothermic peak at $390{ }^{\circ} \mathrm{C}$. The small endothermic peak at $280{ }^{\circ} \mathrm{C}$ could be an artifact caused by the instrument, since it randomly appears in the repeating experiments. The broad peaks detected by both TGA-MS and DSC could be caused by either reaction of $\mathrm{SiO}_{2}$ with $\mathrm{Ca}\left(\mathrm{BH}_{4}\right)_{2}$, or a catalytic effect of $\mathrm{SiO}_{2}$. The TGA-MS and DSC analyses of the $\mathrm{Ca}\left(\mathrm{BH}_{4}\right)_{2}$ and $\mathrm{Al}_{2} \mathrm{O}_{3}$ mixture are shown in Figure 17. The TGA-MS shows two major hydrogen releasing peaks at $357-371{ }^{\circ} \mathrm{C}$ and $433{ }^{\circ} \mathrm{C}$, respectively. The DSC shows two endothermic peaks at $382{ }^{\circ} \mathrm{C}$ and $401{ }^{\circ} \mathrm{C}$ and a broad endothermic peak at $225-357^{\circ} \mathrm{C}$.

The compatibility of $\mathrm{Ca}\left(\mathrm{BH}_{4}\right)_{2}$ with YSZ and $\mathrm{C}$ was also evaluated by TGA-MS and DSC. The samples were prepared by ball milling of $\mathrm{Ca}\left(\mathrm{BH}_{4}\right)_{2}$ with $\mathrm{YSZ}$ and $\mathrm{C}$ aerogel respectively at a 1:1 mole ratio. Figure 18 shows the TGA-MS of the mixture of $\mathrm{Ca}\left(\mathrm{BH}_{4}\right)_{2}$ and $\mathrm{ZrO}_{2}$. TGA-MS analysis indicates a broad hydrogen evolution temperature range from $200{ }^{\circ} \mathrm{C}$ to $>525{ }^{\circ} \mathrm{C}$, with a major peak at $380^{\circ} \mathrm{C}$ and a shoulder peak at $365^{\circ} \mathrm{C}$. The DSC also shows similar reaction features, with a broad endothermic event in the range of $220-350{ }^{\circ} \mathrm{C}$ and an endothermic peak at $390{ }^{\circ} \mathrm{C}$. The broad peaks detected by both TGA-MS and DSC could be due to slow desorption of $\mathrm{H}_{2}$, since it also appears in the SPEX milled $\mathrm{Ca}\left(\mathrm{BH}_{4}\right)_{2}$ (Figure 19). The broadness of the hydrogen releasing peaks indicates that the dehydrogenation of $\mathrm{Ca}\left(\mathrm{BH}_{4}\right)_{2}$ is a complicated process, which may involve numerous small steps.

The TGA-MS and DSC analyses of the mixture of $\mathrm{Ca}\left(\mathrm{BH}_{4}\right)_{2}$ and $\mathrm{C}$ are shown in Figure 20. The TGA-MS shows two major $\mathrm{H}_{2}$ releasing events, with a broad hydrogen peak starting at $180{ }^{\circ} \mathrm{C}$ and reaching peak at $366{ }^{\circ} \mathrm{C}$ and a small peak at $405{ }^{\circ} \mathrm{C}$. The DSC also shows two endothermic peaks at $367{ }^{\circ} \mathrm{C}$ and $394{ }^{\circ} \mathrm{C}$, imposed on a broad endothermic event in the temperature of 225 to $357^{\circ} \mathrm{C}$. 
Screening of Nano-Framework Reactivity with Borohydrides

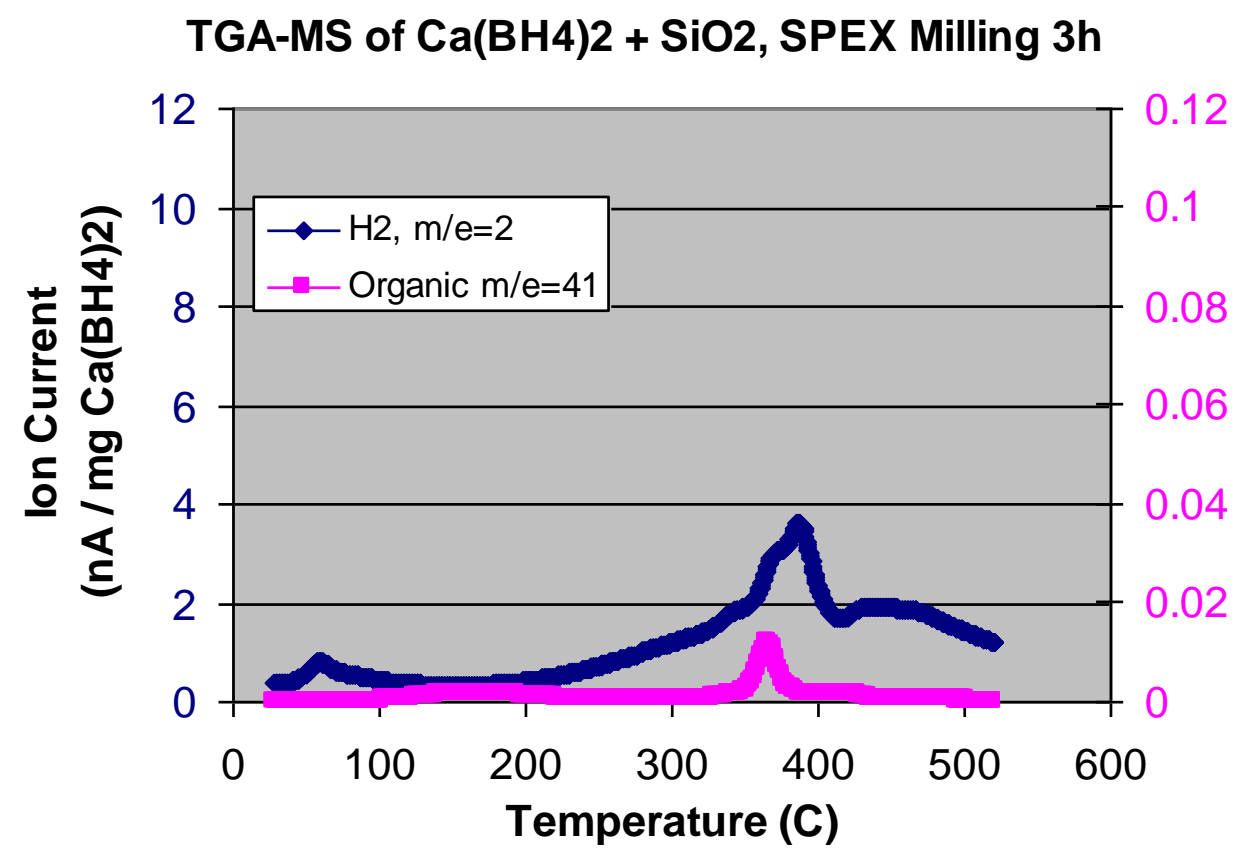

(A)

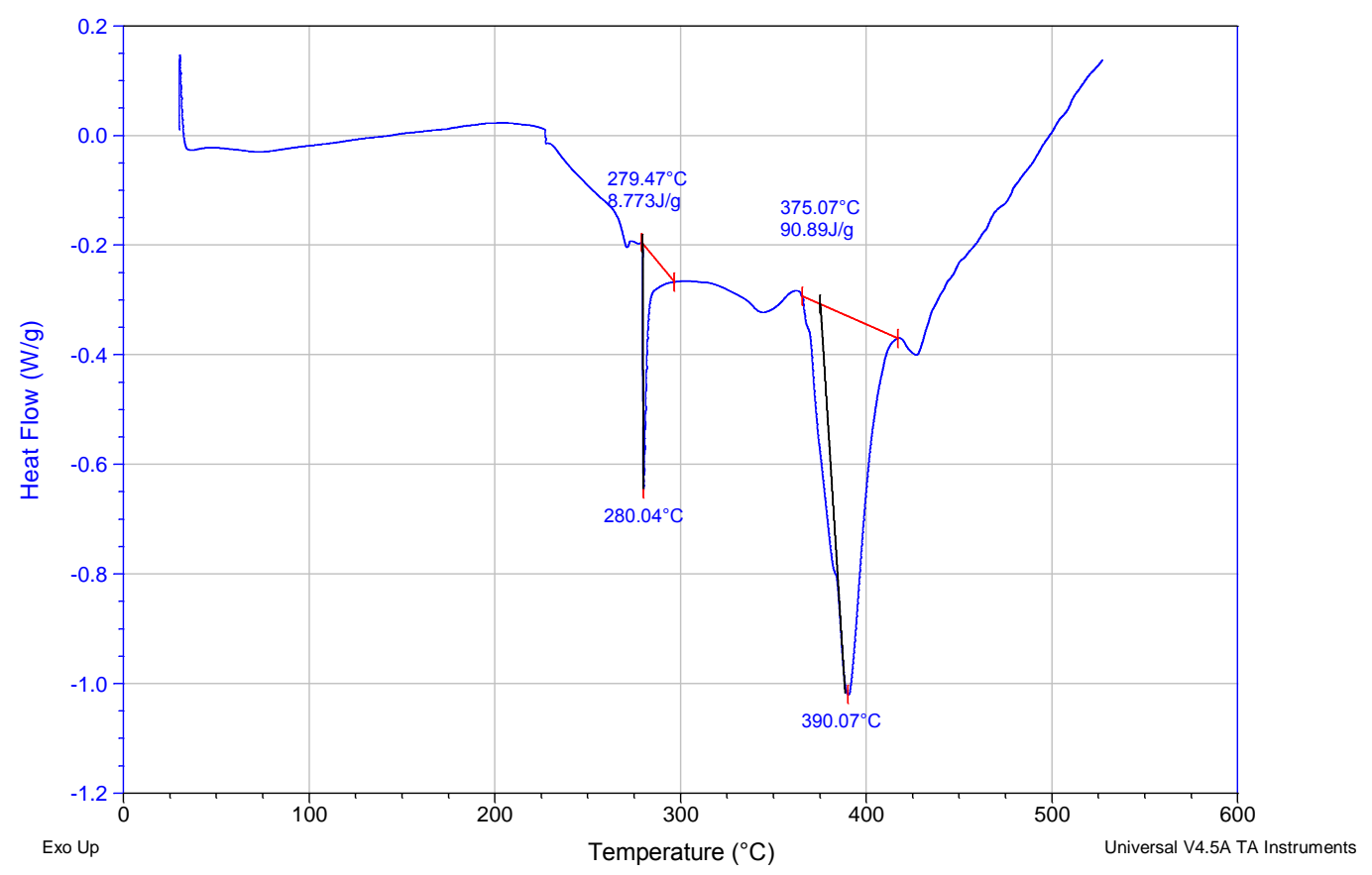

(B)

Figure 16: TGA-MS (A) and DSC (B) of $\mathrm{Ca}\left(\mathrm{BH}_{4}\right)_{2}$ and $\mathrm{SiO}_{2}$ mixture. 
Screening of Nano-Framework Reactivity with Borohydrides

TGA-MS Ca(BH4)2+Al2O3 SPEX Milling $3 \mathrm{hr}$

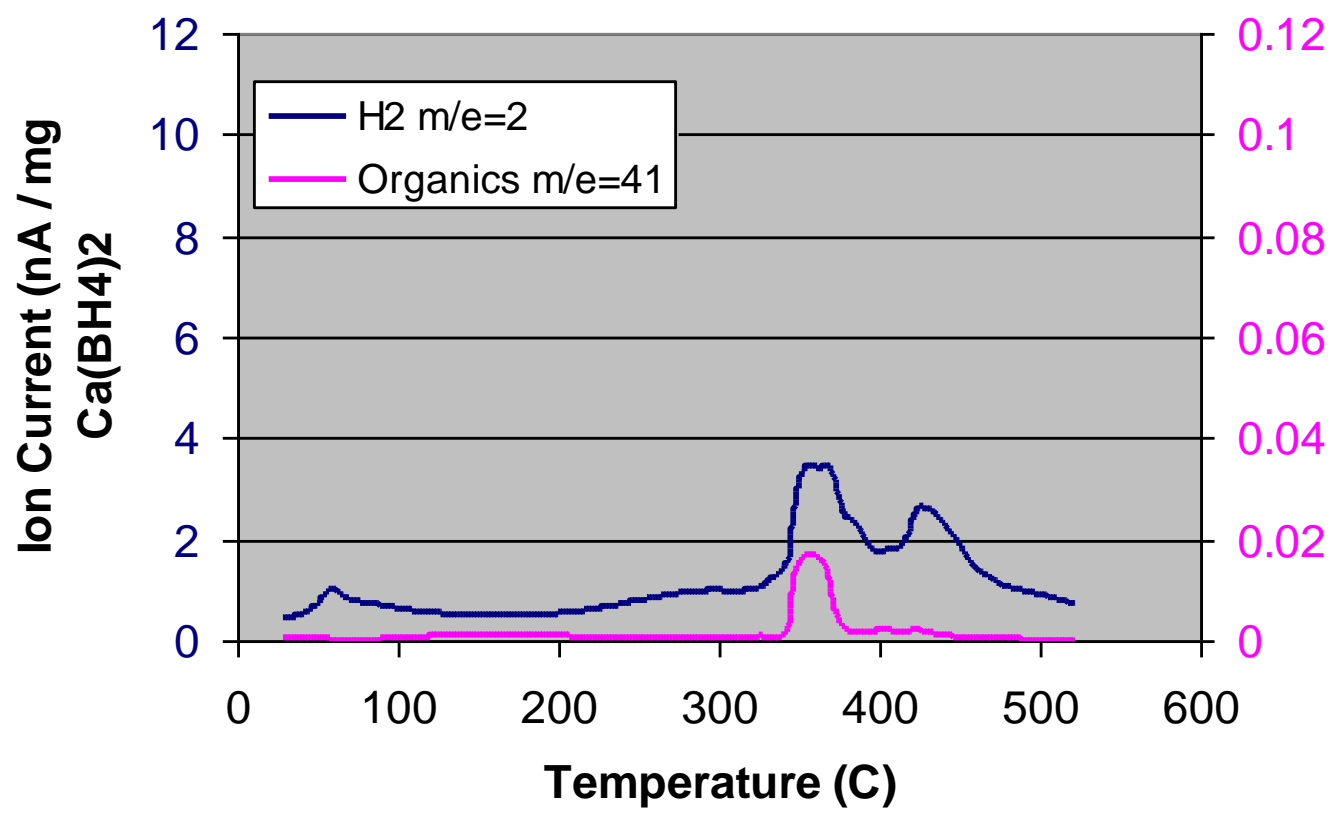

(A)

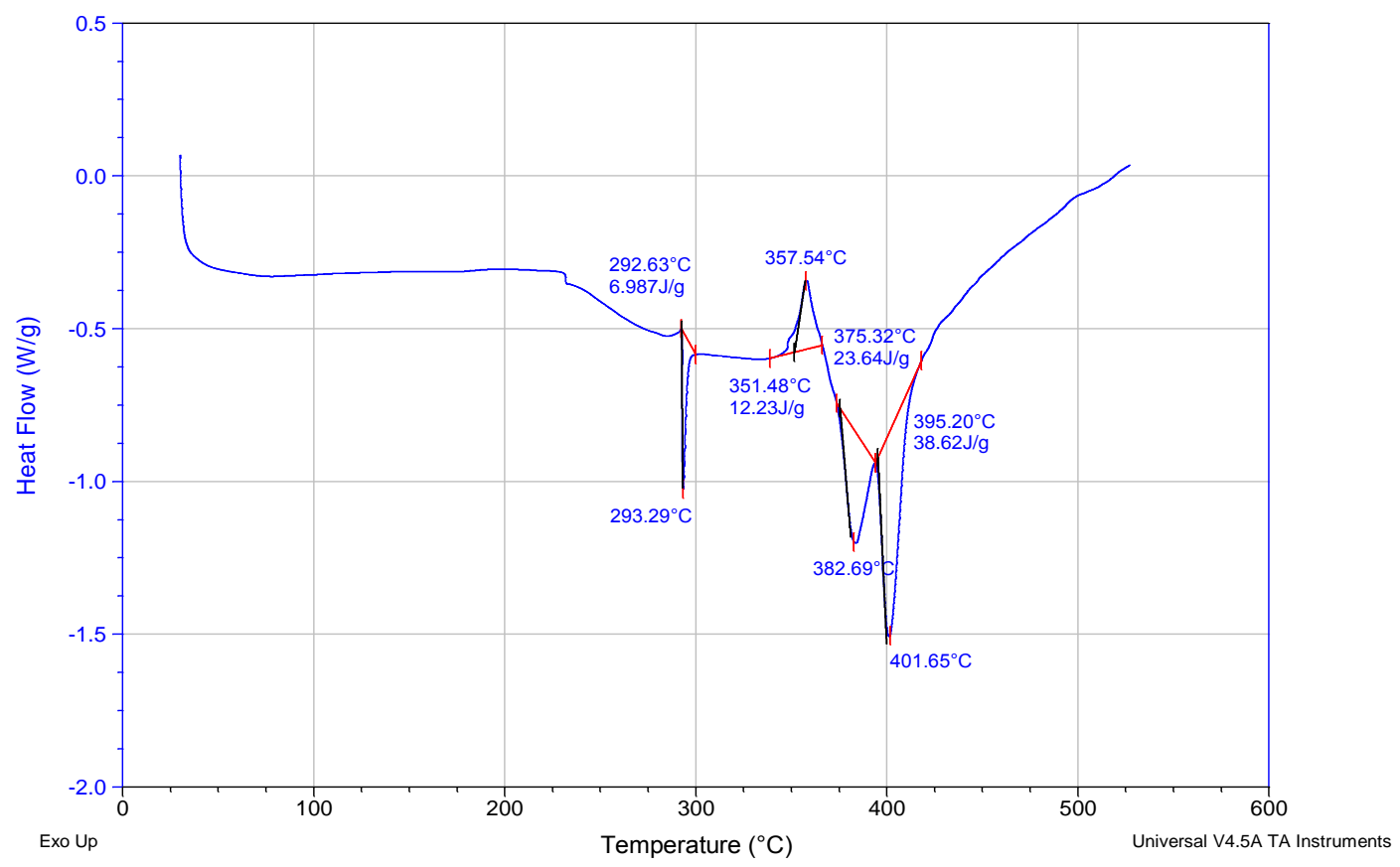

(B)

Figure 17: TGA-MS (A) and DSC (B) of $\mathrm{Ca}\left(\mathrm{BH}_{4}\right)_{2}$ and $\mathrm{Al}_{2} \mathrm{O}_{3}$ mixture. 


\section{Screening of Nano-Framework Reactivity with Borohydrides}

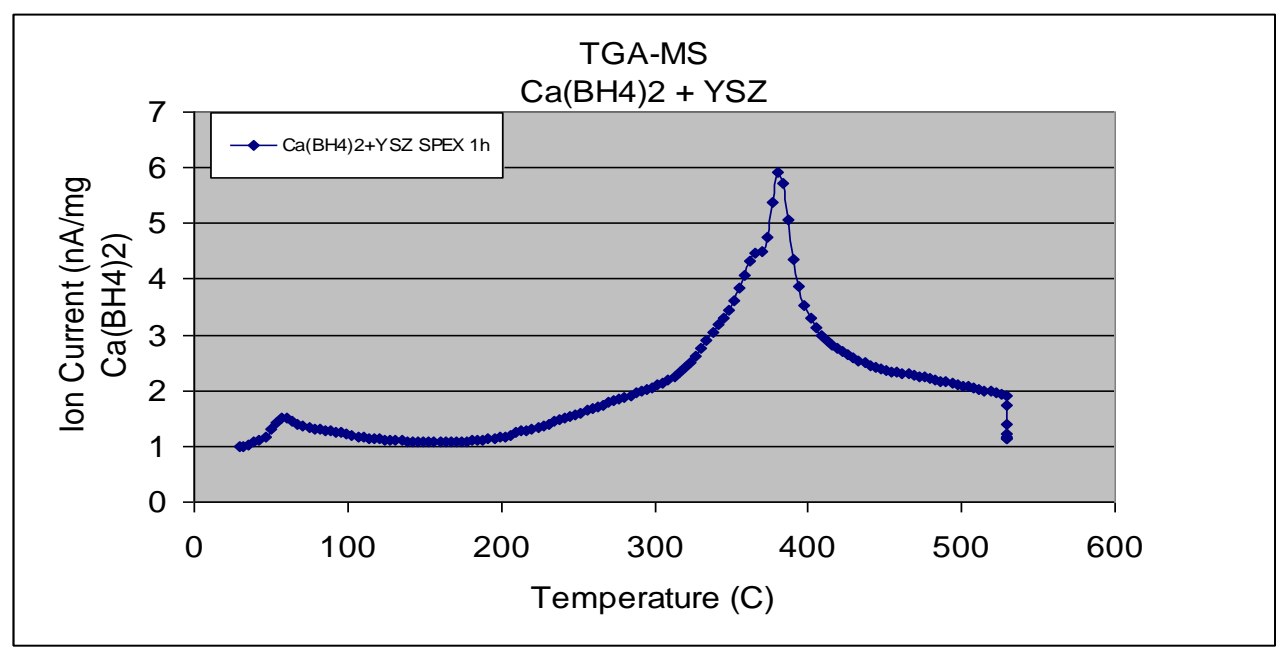

(A)

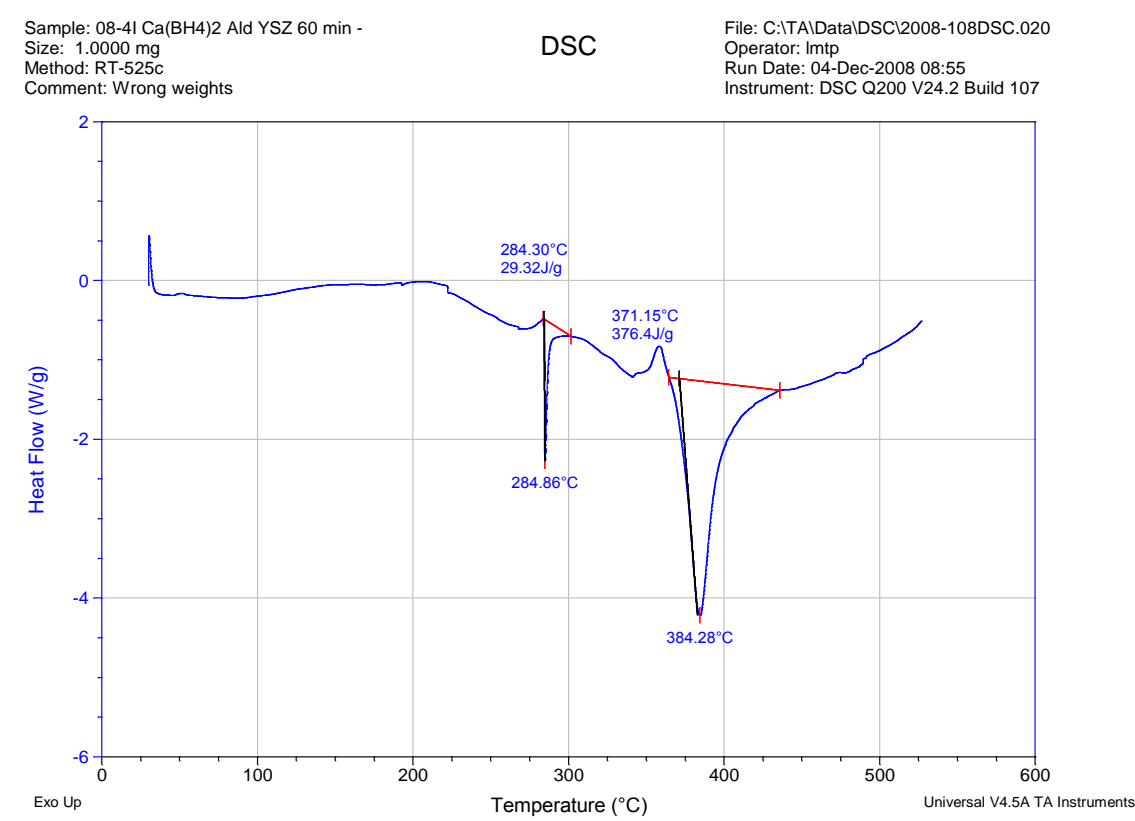

(B)

Figure 18: TGA-MS (A) and DSC(B) of reaction mixture of $\mathrm{Ca}\left(\mathrm{BH}_{4}\right)_{2}$ with YSZ. 


\section{Screening of Nano-Framework Reactivity with Borohydrides}

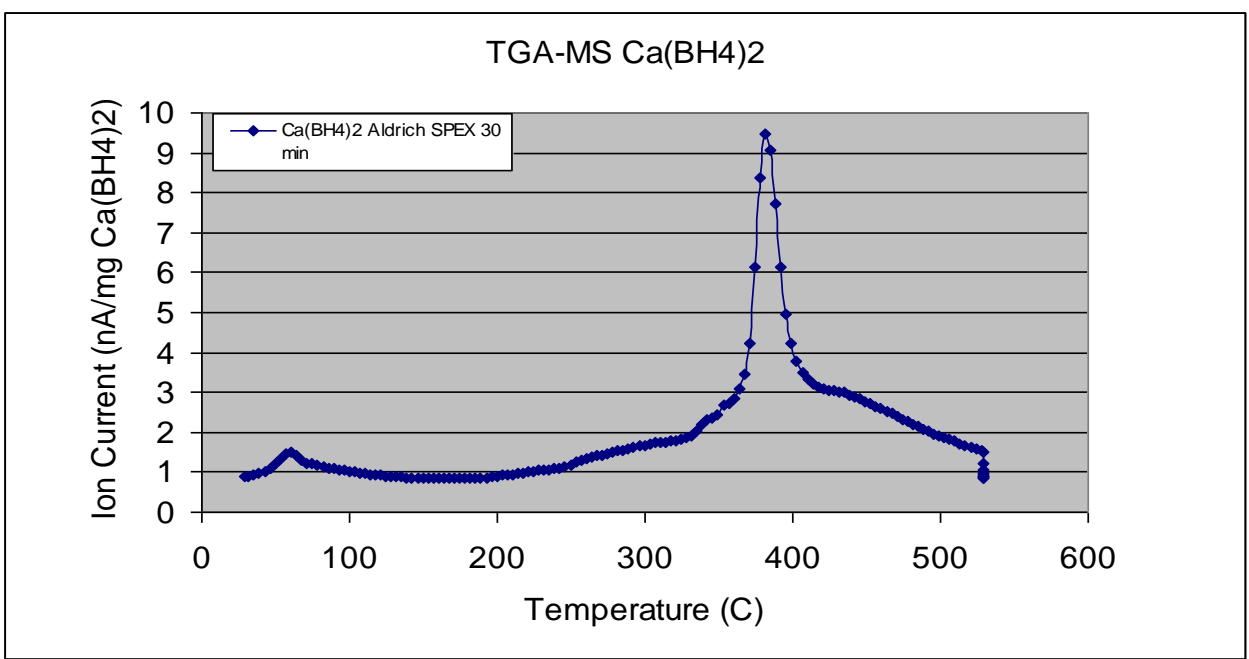

(A)

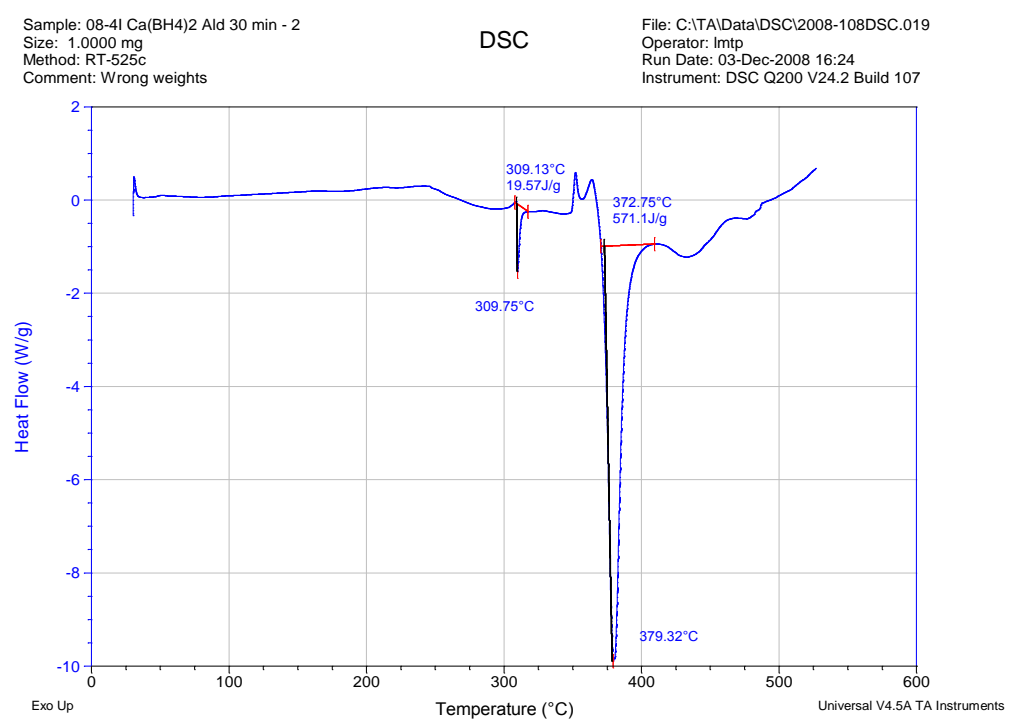

(B)

Figure 19: TGA-MS (A) and DSC(B) of $\mathrm{Ca}\left(\mathrm{BH}_{4}\right)_{2}$, SPEX milled for 30 min. 


\section{Screening of Nano-Framework Reactivity with Borohydrides}

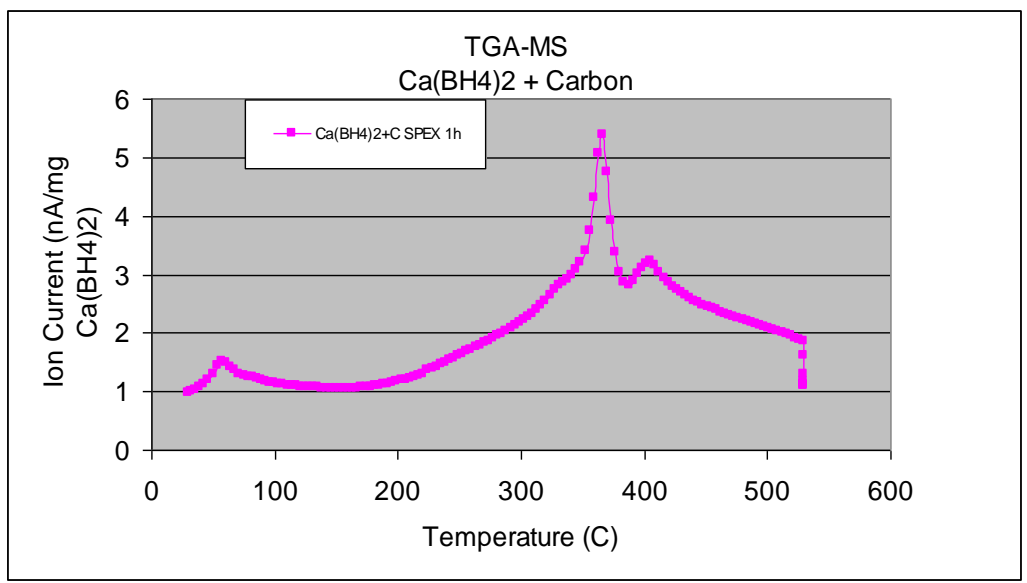

(A)

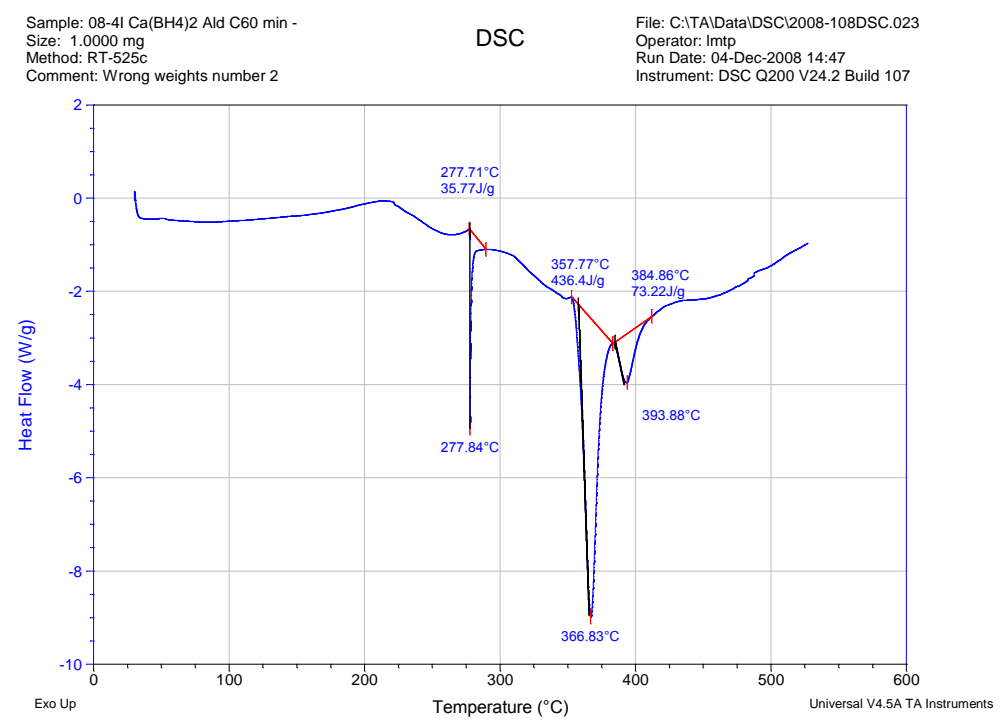

(B)

Figure 20: TGA-MS and DSC of $\mathrm{Ca}\left(\mathrm{BH}_{4}\right)_{2}$ mixed with carbon.

In order to further examine $\mathrm{Ca}\left(\mathrm{BH}_{4}\right)_{2}$ reactivity, mixtures of $\mathrm{Ca}\left(\mathrm{BH}_{4}\right)_{2}$ with $\mathrm{SiO}_{2}, \mathrm{Al}_{2} \mathrm{O}_{3}, \mathrm{YSZ}$ and $\mathrm{C}$ material were first discharged at $350{ }^{\circ} \mathrm{C}$ under 1 bar hydrogen for 24 hours. All mixtures released about $6 \mathrm{wt} \%$ of $\mathrm{H}_{2}$ during desorption. The samples were then recharged under $350{ }^{\circ} \mathrm{C} / 190$ bar $\mathrm{H}_{2}$ for 24 hours. The recharged sample was analyzed by XRD for the formation of $\mathrm{Ca}\left(\mathrm{BH}_{4}\right)_{2}$ and other reaction products.

The XRD spectra of SPEX milled $\mathrm{Ca}\left(\mathrm{BH}_{4}\right)_{2}$ at various stages of cycling are shown in Figure 21. Formation of $\mathrm{Ca}\left(\mathrm{BH}_{4}\right)_{2}$ was observed after recharging. Both $\mathrm{Ca}\left(\mathrm{BH}_{4}\right)_{2}-\mathrm{SiO}_{2}$ and $\mathrm{Ca}\left(\mathrm{BH}_{4}\right)_{2}-\mathrm{Al}_{2} \mathrm{O}_{3}$ mixtures have shown only trace amount of products from the reaction of the hydride and framework materials, however, no formation of $\mathrm{Ca}\left(\mathrm{BH}_{4}\right)_{2}$ was observed after recharging in these two mixtures. 


\section{Screening of Nano-Framework Reactivity with Borohydrides}

Figure 22 shows the $\mathrm{XRD}$ of $\mathrm{Ca}\left(\mathrm{BH}_{4}\right)_{2}-\mathrm{YSZ}$ mixture. No reaction product was observed in the YSZ system. Formation of small amount $\mathrm{Ca}\left(\mathrm{BH}_{4}\right)_{2}$ was observed after recharging in

$\mathrm{Ca}\left(\mathrm{BH}_{4}\right)_{2}-\mathrm{YSZ}$ mixture. Figure 23 shows the XRD spectra of $\mathrm{Ca}\left(\mathrm{BH}_{4}\right)_{2}-\mathrm{C}(\mathrm{PI})$ mixture. A small amount of calcium nitride was observed in the $\mathrm{Ca}\left(\mathrm{BH}_{4}\right)_{2}-\mathrm{C}(\mathrm{PI})$ system. This was resulted from $\mathrm{Ca}\left(\mathrm{BH}_{4}\right)_{2}$ reacting with the surface $\mathrm{N}$-containing species in $\mathrm{C}$ aerogel. A trace amount of calcium borate species was observed in all samples. This may be caused by the $\mathrm{O}$ from THF impurity as it was decomposed. A significant quantity of $\mathrm{Ca}\left(\mathrm{BH}_{4}\right)_{2}$ (low temperature phase) was formed after indicating positive impact of $\mathrm{C}$ aerogel on hydride formation. This $\mathrm{C}(\mathrm{PI})$ aerogel nitrogen. In order to eliminate the formation of nitride in $\mathrm{Ca}\left(\mathrm{BH}_{4}\right)_{2}-\mathrm{C}$ aerogel, a $\mathrm{N}$ aerogel material $\mathrm{C}(\mathrm{PF})$ was tested as a replacement. The $\mathrm{C}(\mathrm{PF})$ aerogel contained reactivity screening test was again conducted with a $\mathrm{Ca}\left(\mathrm{BH}_{4}\right)_{2}-\mathrm{C}(\mathrm{PF})$ mixture ball milling.

Figure 24 shows the XRD spectrum of the $\mathrm{Ca}\left(\mathrm{BH}_{4}\right)_{2}-\mathrm{C}(\mathrm{PF})$ aerogel mixture after discharge and recharge (in black), in comparison with that of $\mathrm{Ca}\left(\mathrm{BH}_{4}\right)_{2}$ alone (in light blue). No N-containing reaction products were observed in the $\mathrm{Ca}\left(\mathrm{BH}_{4}\right)_{2}-\mathrm{C}(\mathrm{PF})$ mixture. A trace amount of calcium borate species was observed in both samples. Based on the results, YSZ and $\mathrm{C}(\mathrm{PF})$ aerogel materials were down-selected as nano-framework candidates for $\mathrm{Ca}\left(\mathrm{BH}_{4}\right)_{2}$ going forward.

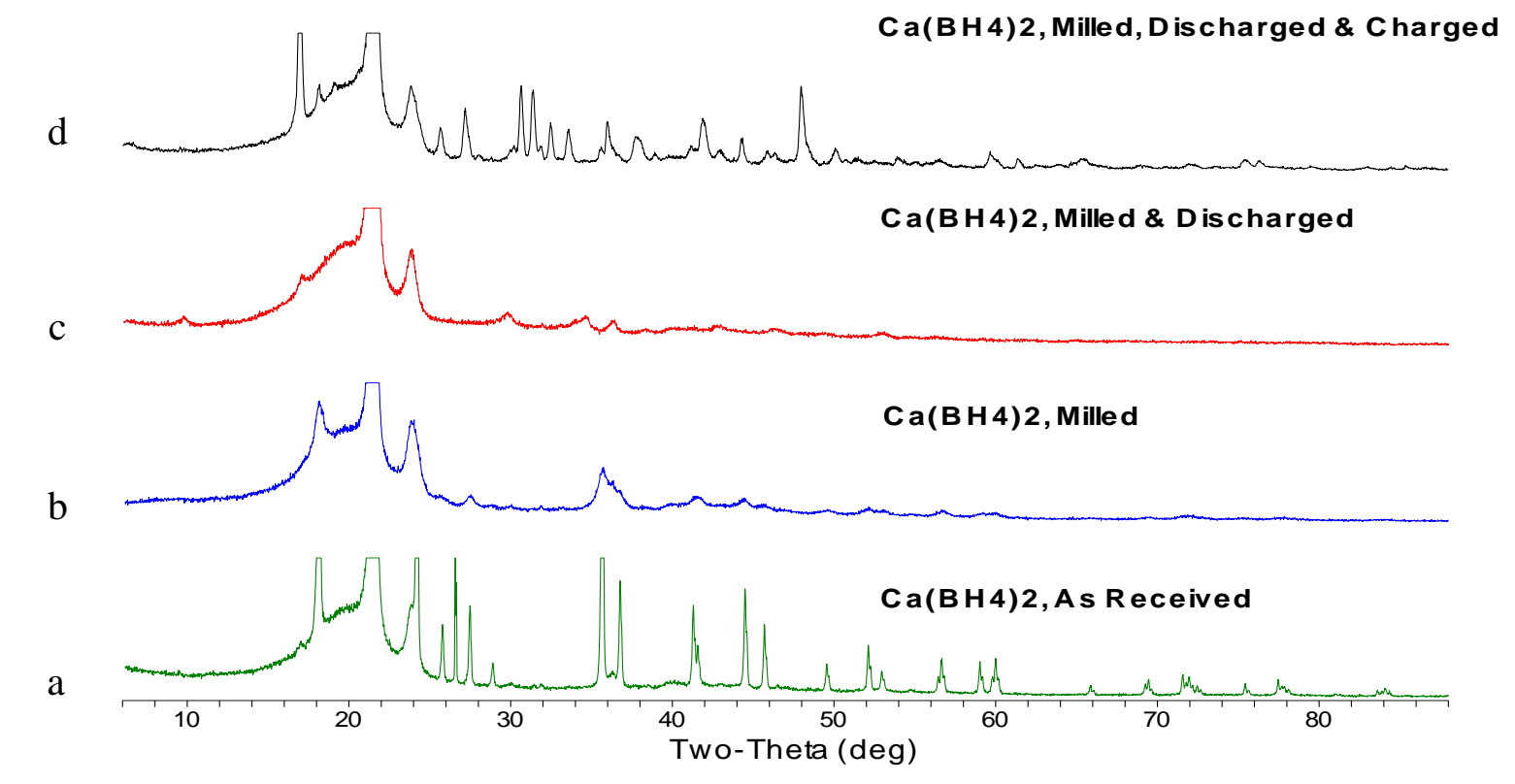




\section{Screening of Nano-Framework Reactivity with Borohydrides}

Figure 21: XRD of SPEX milled $\mathrm{Ca}\left(\mathrm{BH}_{4}\right)_{2}$ at various stages of cycling

a) As received $\mathrm{Ca}\left(\mathrm{BH}_{4}\right)_{2}$.

b) $\mathrm{Ca}\left(\mathrm{BH}_{4}\right)_{2}$ SPEX milled.

c) $\mathrm{Ca}\left(\mathrm{BH}_{4}\right)_{2}$ SPEX milled and discharged.

d) $\mathrm{Ca}\left(\mathrm{BH}_{4}\right)_{2}$ SPEX milled and discharged and charged.

c

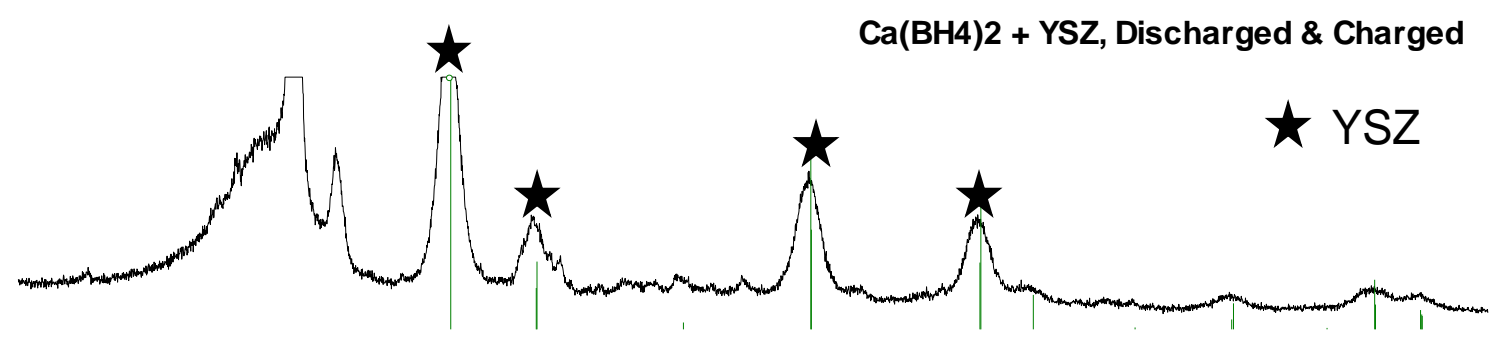

b

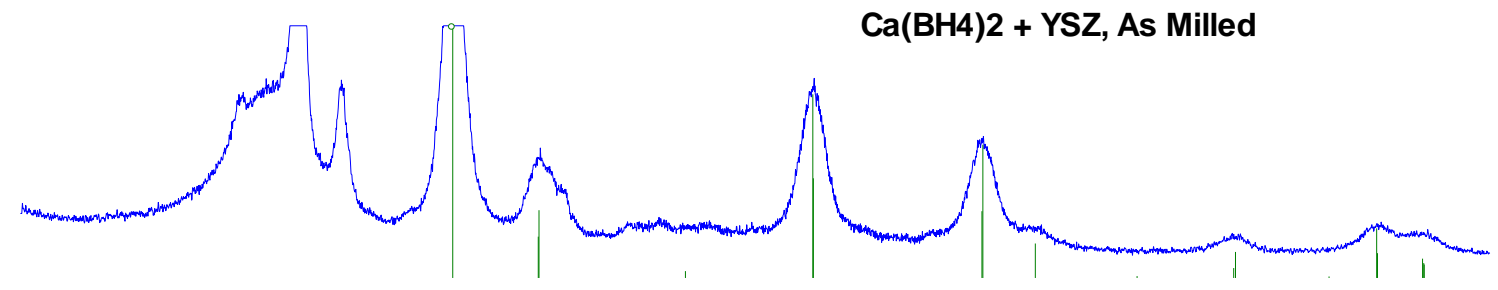

a

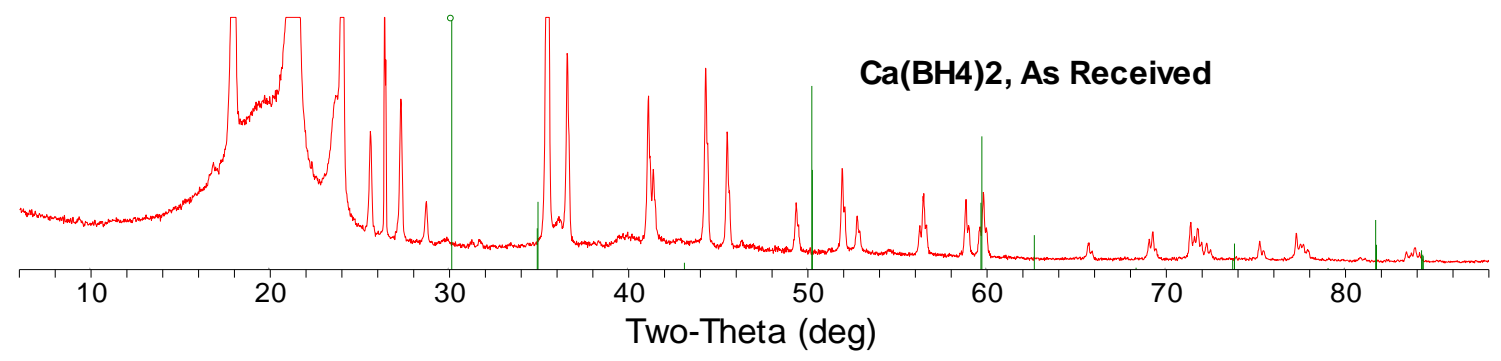

Figure 22: XRD of $\mathrm{Ca}\left(\mathrm{BH}_{4}\right)_{2}$ SPEX milled with YSZ

a) As received $\mathrm{Ca}\left(\mathrm{BH}_{4}\right)_{2}$.

b) $\mathrm{Ca}\left(\mathrm{BH}_{4}\right)_{2}$ SPEX milled with YSZ.

c) $\mathrm{Ca}\left(\mathrm{BH}_{4}\right)_{2} \mathrm{SPEX}$ milled with YSZ, discharged and charged. 


\section{Screening of Nano-Framework Reactivity with Borohydrides}

$\mathrm{c}$

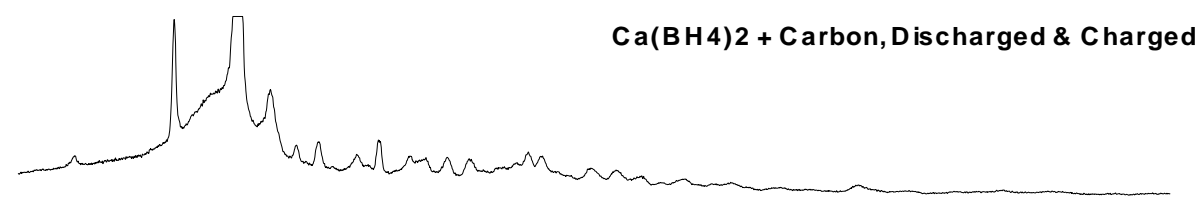

b

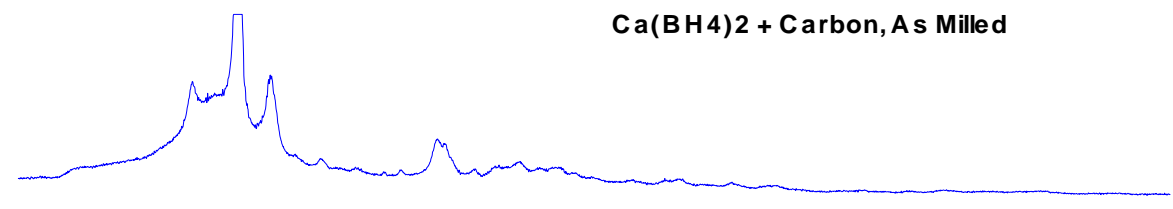

$\mathrm{a}$

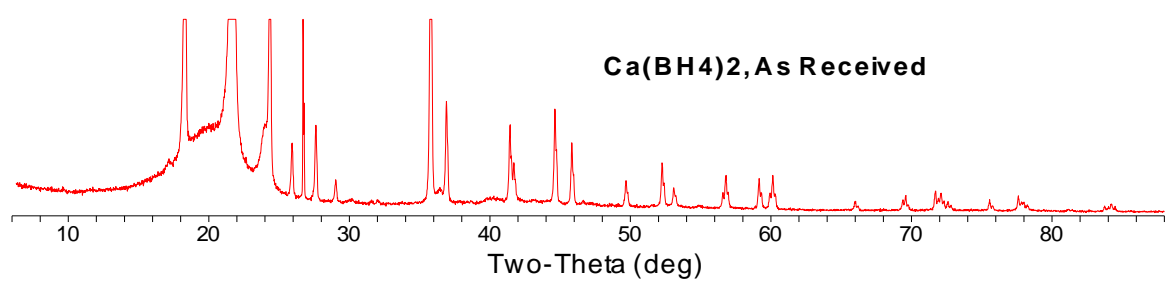

Figure 23: XRD spectra of $\mathrm{Ca}\left(\mathrm{BH}_{4}\right)_{2}$ SPEX milled with carbon aerogel

a) As received $\mathrm{Ca}\left(\mathrm{BH}_{4}\right)_{2}$.

b) $\mathrm{Ca}\left(\mathrm{BH}_{4}\right)_{2}$ SPEX milled with carbon aerogel.

c) $\mathrm{Ca}\left(\mathrm{BH}_{4}\right)_{2} \mathrm{SPEX}$ milled with carbon aerogel, discharged and charged.

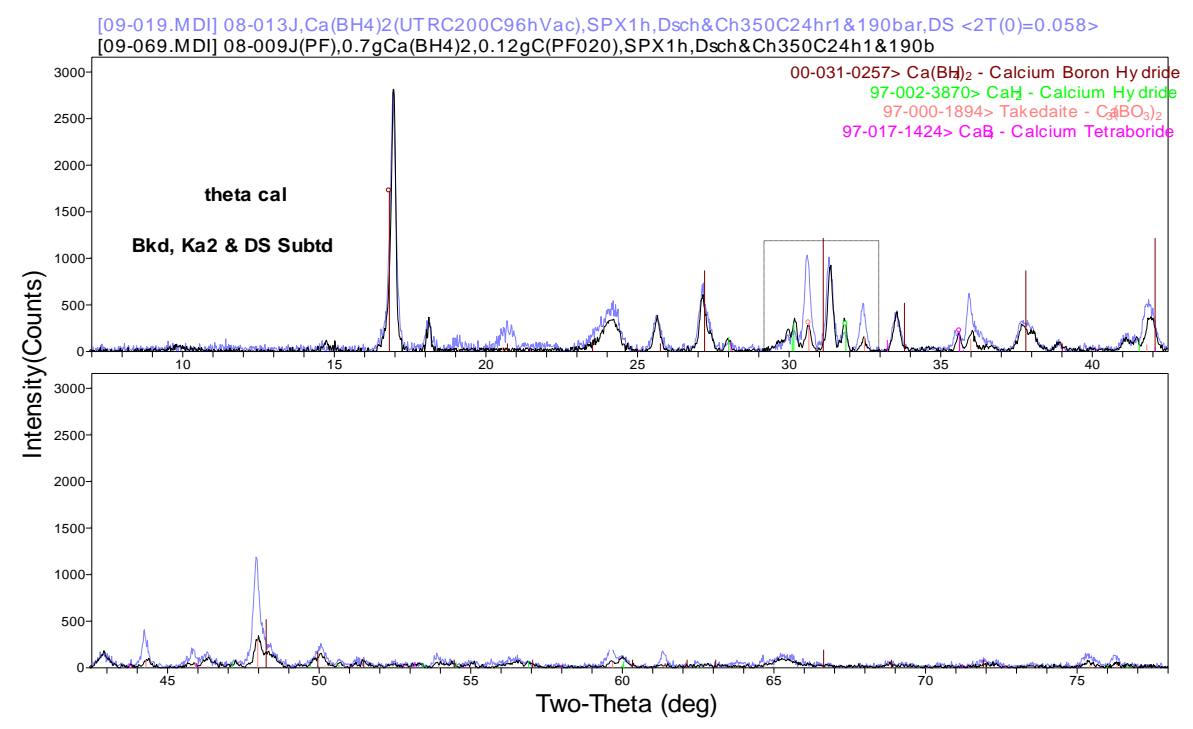

Figure 24: $\mathrm{XRD}$ of $\mathrm{Ca}\left(\mathrm{BH}_{4}\right)_{2}-\mathrm{C}(\mathrm{PF})$ mixtures after discharge at $350{ }^{\circ} \mathrm{C} / 1$ bar and recharge at 350 ${ }^{\circ} \mathrm{C} / 190$ bar $\mathrm{H}_{2}$. 


\section{Screening of Nano-Framework Reactivity with Borohydrides}

\section{4 $\mathrm{H}_{2}$ Desorption and Absorption of $\mathrm{Ca}\left(\mathrm{BH}_{4}\right)_{2}$ SPEX Milled with Carbon Aerogels}

The impact on of C aerogels on hydride kinetics and its reversibility was evaluated using a Sievert's apparatus.

Figure 25 shows the $\mathrm{H}_{2}$ desorption curves of $\mathrm{Ca}\left(\mathrm{BH}_{4}\right)_{2}$ and the SPEX milled mixtures of $\mathrm{Ca}\left(\mathrm{BH}_{4}\right)_{2}$ with $\mathrm{C}(\mathrm{PI})$ and $\mathrm{C}(\mathrm{PF})$ aerogels respectively. In the first $\mathrm{H}_{2}$ desorption, mixtures of $\mathrm{Ca}\left(\mathrm{BH}_{4}\right)_{2}$ with $\mathrm{C}$ aerogels has similar $\mathrm{H}_{2}$ release rates. Both samples release $\mathrm{H}_{2}$ faster than $\mathrm{Ca}\left(\mathrm{BH}_{4}\right)_{2}$ by itself. In the second desorption, the amount of $\mathrm{H}_{2}$ released is only about $50 \%$ of the amount released in the first desorption. This is caused by incomplete $\mathrm{H}_{2}$ absorption. $\mathrm{Ca}\left(\mathrm{BH}_{4}\right)_{2}$ mixed with $\mathrm{C}(\mathrm{PF})$ shows a faster desorption rate than the mixture with $\mathrm{C}(\mathrm{PI})$ aerogel in the second desorption. This indicates that the surface chemistry of nano-framework materials can affect hydride kinetics.

$1^{\text {st }}$ Desorption

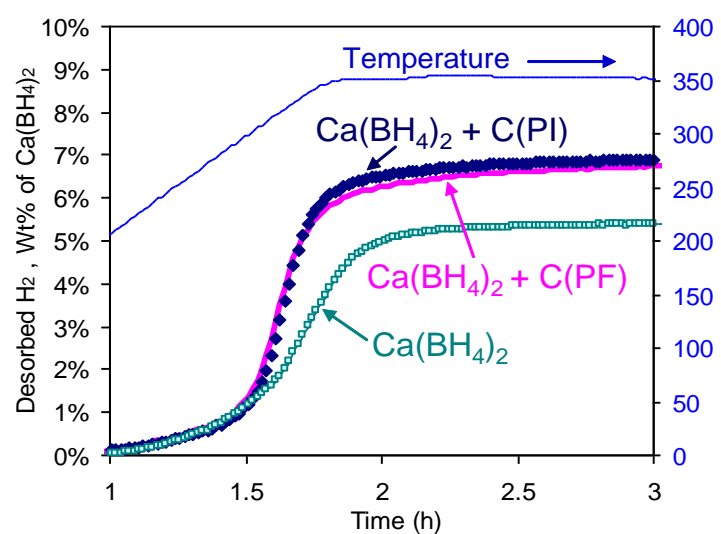

$2^{\text {nd }}$ Desorption

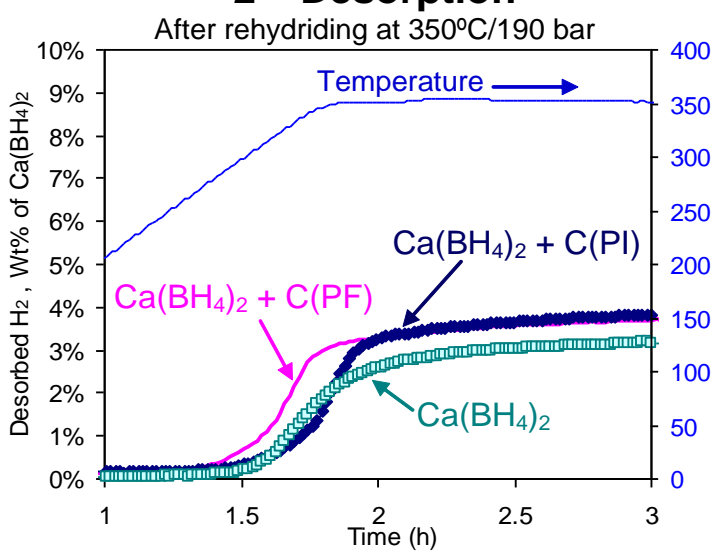

Figure 25: Hydrogen desorption of $\mathrm{Ca}\left(\mathrm{BH}_{4}\right)_{2}$ mixed with $\mathrm{C}$ aerogels.

\subsection{Hydrogen Desorption and Absorption of $\mathrm{Ca}\left(\mathrm{BH}_{4}\right)_{2} \mathrm{SPEX}$ Milled with Uncatalyzed and Pt- Catalyzed $\mathrm{ZrO}_{2}$ Aerogel (UTRC)}

The effect of Pt-catalyzed yittria-stabilized $\mathrm{ZrO}_{2}$ aerogel ( $\mathrm{Pt} / \mathrm{YSZ}$ ) on $\mathrm{Ca}\left(\mathrm{BH}_{4}\right)_{2}$ reversibility was first tested in SPEX milled mixture. This is a baseline test for assessing the performance of $\mathrm{Ca}\left(\mathrm{BH}_{4}\right)_{2}$ incorporated in Pt-catalyzed $\mathrm{ZrO}_{2}$ aerogel. Figure 27 shows the $1^{\text {st }} \mathrm{H}_{2}$ desorption of $\mathrm{Ca}\left(\mathrm{BH}_{4}\right)_{2} \mathrm{SPEX}$ milled with Pt-catalyzed $\mathrm{ZrO}_{2}$ aerogel, in comparison with SPEX milled $\mathrm{Ca}\left(\mathrm{BH}_{4}\right)_{2}$ and its mixture with uncatalyzed $\mathrm{ZrO}_{2}$ aerogel (YSZ).

$\mathrm{Ca}\left(\mathrm{BH}_{4}\right)_{2}$ mixtures with uncatalyzed YSZ and Pt/YSZ have similar desorption kinetics in the $1^{\text {st }}$ cycle, starting to release $\mathrm{H}_{2}$ at $150{ }^{\circ} \mathrm{C}$. A total of $\mathrm{ca}$. $7.8 \mathrm{wt} \%$ of $\mathrm{H}_{2}$ was released. Again, less than $4 \mathrm{wt} \%$ of $\mathrm{H}_{2}$ was released in the second cycle following absorption at $350{ }^{\circ} \mathrm{C} / 180$ bar for 24 hours. The Pt/YSZ has better kinetics and slightly higher kinetics than the uncatalyzed YSZ in second desorption, indicating Pt may catalyzed $\mathrm{H}_{2}$ absorption and desorption of $\mathrm{Ca}\left(\mathrm{BH}_{4}\right)_{2}$.

Figure 27 shows the $1^{\text {st }} \mathrm{H}_{2}$ desorption of $\mathrm{Ca}\left(\mathrm{BH}_{4}\right)_{2}$ SPEX milled with Pt/YSZ, in comparison with SPEX milled $\mathrm{Ca}\left(\mathrm{BH}_{4}\right)_{2}$ and its mixture with $\mathrm{C}(\mathrm{PF})$ aerogel. $\mathrm{Ca}\left(\mathrm{BH}_{4}\right)_{2}$ mixed with $\mathrm{Pt} / \mathrm{YSZ}$ has the lowest onset temperature of $\mathrm{H}_{2}$ release among all three samples. It released a total of $c a .7 .8 \mathrm{wt} \% \mathrm{H}_{2}$, the highest among three samples. Its desorption kinetics, however, was slower than the mixture with $\mathrm{C}(\mathrm{PF})$ aerogel at temperature range of $250-350{ }^{\circ} \mathrm{C}$. Figure 28 shows the $2^{\text {nd }}$ desorption curve after absorption at $350{ }^{\circ} \mathrm{C} / 190$ bar $\mathrm{H}_{2}$ pressure. Although the mixture of $\mathrm{Ca}\left(\mathrm{BH}_{4}\right)_{2}$ with $\mathrm{Pt} / \mathrm{YSZ}$ released 


\section{Screening of Nano-Framework Reactivity with Borohydrides}

only $3.2 \mathrm{wt} \% \mathrm{H}_{2}$, lower than the amount released from $\mathrm{Ca}\left(\mathrm{BH}_{4}\right)_{2}-\mathrm{C}(\mathrm{PF})$ mixture, it again shows the best desorption kinetics. This further indicates that $\mathrm{Pt}$ may have an effect in catalyzing $\mathrm{H}_{2} \mathrm{desorption}_{\text {. }}$

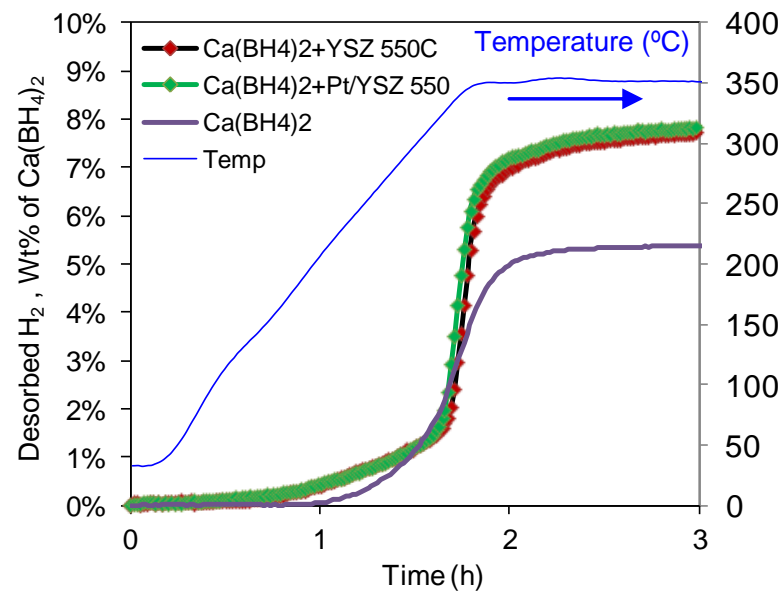

(A) $1^{\text {st }}$ Desorption

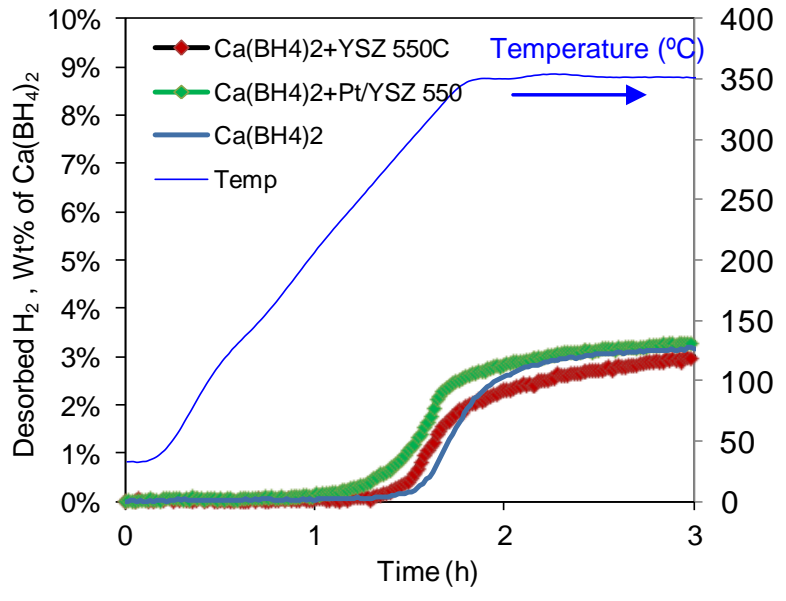

(B) 2nd desorption

Figure 26: $\mathrm{H}_{2}$ desorption of $\mathrm{Ca}\left(\mathrm{BH}_{4}\right)_{2}$ SPEX milled with uncatalyzed and Pt-catalyzed YSZ.

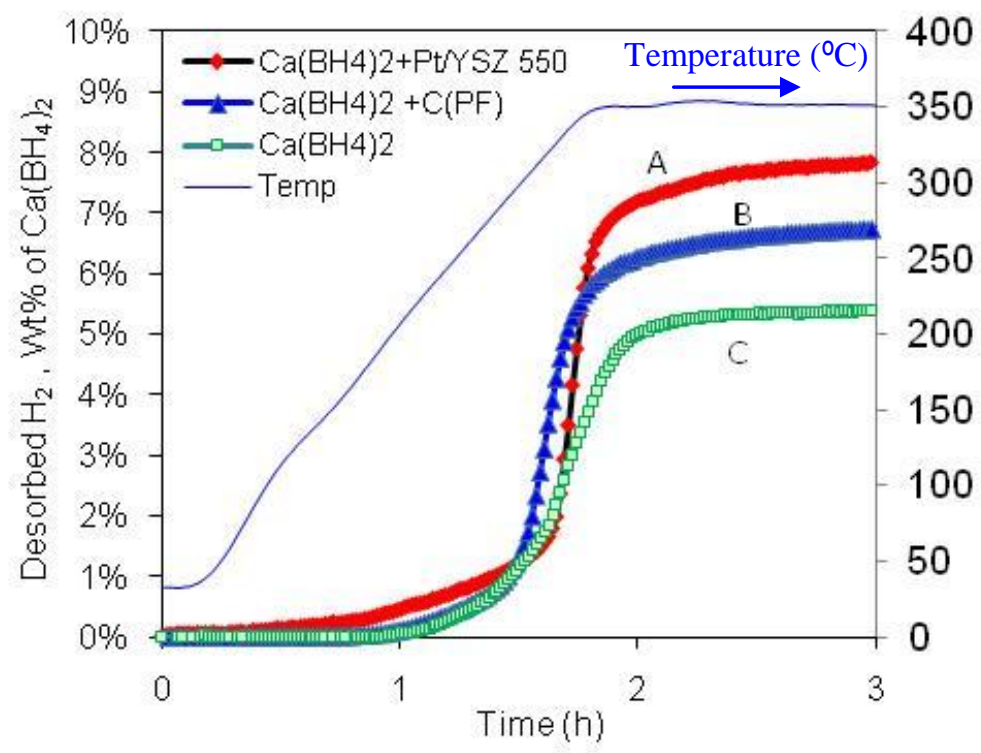

Figure 27: 1 st $\mathrm{H}_{2}$ desorption of:

(A) $\mathrm{Ca}\left(\mathrm{BH}_{4}\right)_{2}$ SPEX milled with $\mathrm{Pt} / \mathrm{ZrO}_{2}$.

(B) $\mathrm{Ca}\left(\mathrm{BH}_{4}\right)_{2}$ SPEX milled with $\mathrm{C}(\mathrm{PF})$.

(C) $\mathrm{Ca}\left(\mathrm{BH}_{4}\right)_{2}$ SPEX milled. 


\section{Screening of Nano-Framework Reactivity with Borohydrides}

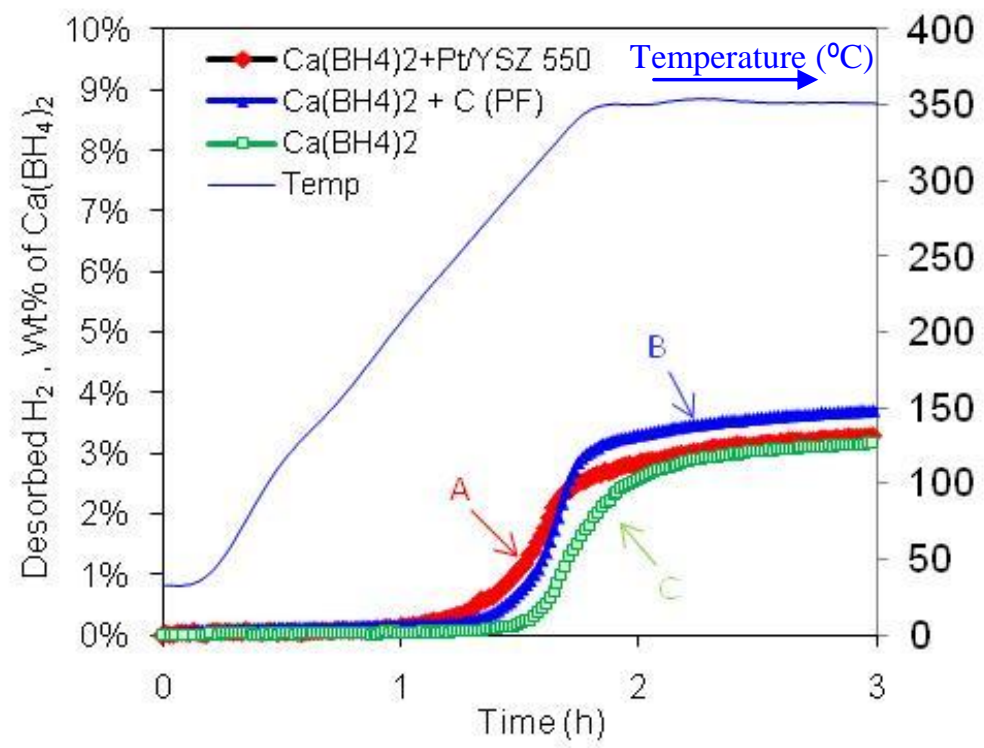

Figure 28: $2^{\text {nd }} \mathrm{H}_{2}$ desorption after rehydrogenation at $350{ }^{\circ} \mathrm{C}, 190$ bar of $\mathrm{H}_{2}$
(A) $\mathrm{Ca}\left(\mathrm{BH}_{4}\right)_{2}$ SPEX milled with Pt/YSZ
(B) $\mathrm{Ca}\left(\mathrm{BH}_{4}\right)_{2}$ SPEX milled with $\mathrm{C}(\mathrm{PF})$.
(C) $\mathrm{Ca}\left(\mathrm{BH}_{4}\right)_{2}$ SPEX milled.

In order to optimize calcination temperature of YSZ aerogel, Pt were loaded on YSZ aerogels calcined at two temperatures: $400{ }^{\circ} \mathrm{C}$ and $550{ }^{\circ} \mathrm{C}$. The YSZ aerogels calcined at $400{ }^{\circ} \mathrm{C}$ had a higher surface area and could potentially have better catalytic effect than the YSZ calcined at $550{ }^{\circ} \mathrm{C}$. Both materials were evaluated for their effect on $\mathrm{Ca}\left(\mathrm{BH}_{4}\right)_{2}$ kinetics and reversibility using SPEX milled mixtures. The $1^{\text {st }}$ and $2^{\text {nd }} \mathrm{H}_{2}$ desorption curves of $\mathrm{Ca}\left(\mathrm{BH}_{4}\right)_{2}$ mixed with the two $\mathrm{Pt} / \mathrm{YSZ}$ aerogels are shown in Figure 29 and Figure 30. Although the mixture with $\mathrm{Pt} / \mathrm{YSZ} / 550{ }^{\circ} \mathrm{C}$ released less $\mathrm{H}_{2}$ in the $1^{\text {st }}$ desorption than the mixture with $\mathrm{Pt} / \mathrm{YSZ} / 400{ }^{\circ} \mathrm{C}$, it absorbed more $\mathrm{H}_{2}$ during rehydriding, shown by higher amount of $\mathrm{H}_{2}$ released in the $2^{\text {nd }}$ desorption. This could be due to the smaller amount of hydroxyl group remained on YSZ aerogel surface when calcined at higher temperature. The surface hydroxyl can react with hydride irreversibly, causing reduced reversibility. Therefore, the YSZ aerogel calcined at $550^{\circ} \mathrm{C}$ was selected for incorporation experiment. 
Screening of Nano-Framework Reactivity with Borohydrides

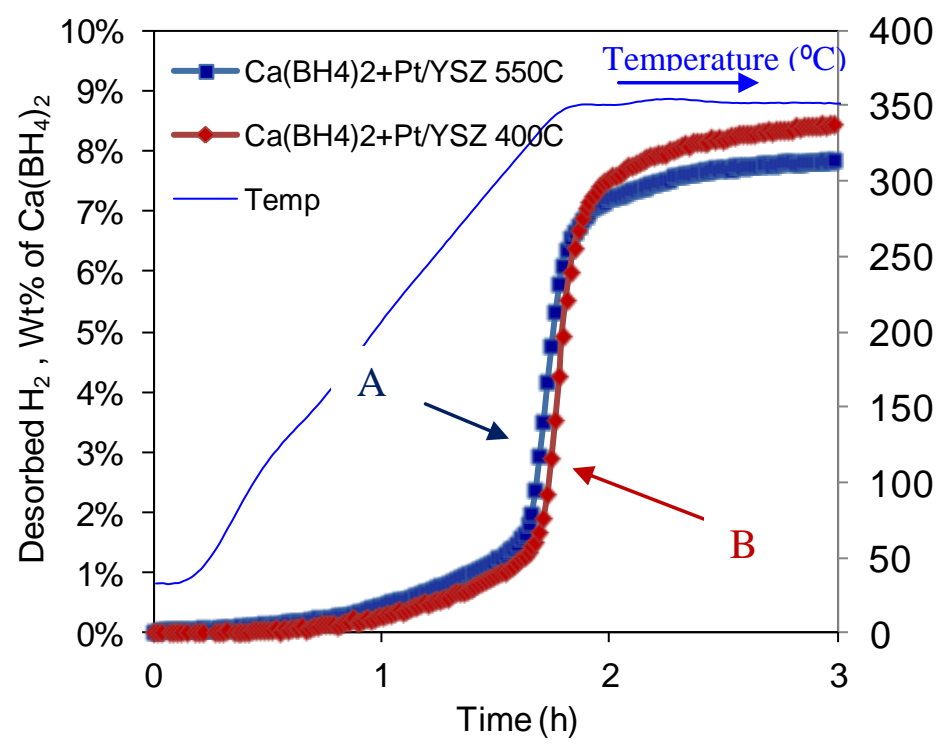

Figure 29: $1^{\text {st }} \mathrm{H}_{2}$ desorption of

(A) $\mathrm{Ca}\left(\mathrm{BH}_{4}\right)_{2}$ SPEX milled with Pt/YSZ $550{ }^{\circ} \mathrm{C}$.

(B) $\mathrm{Ca}\left(\mathrm{BH}_{4}\right)_{2}$ SPEX milled with Pt/YSZ $400{ }^{\circ} \mathrm{C}$.

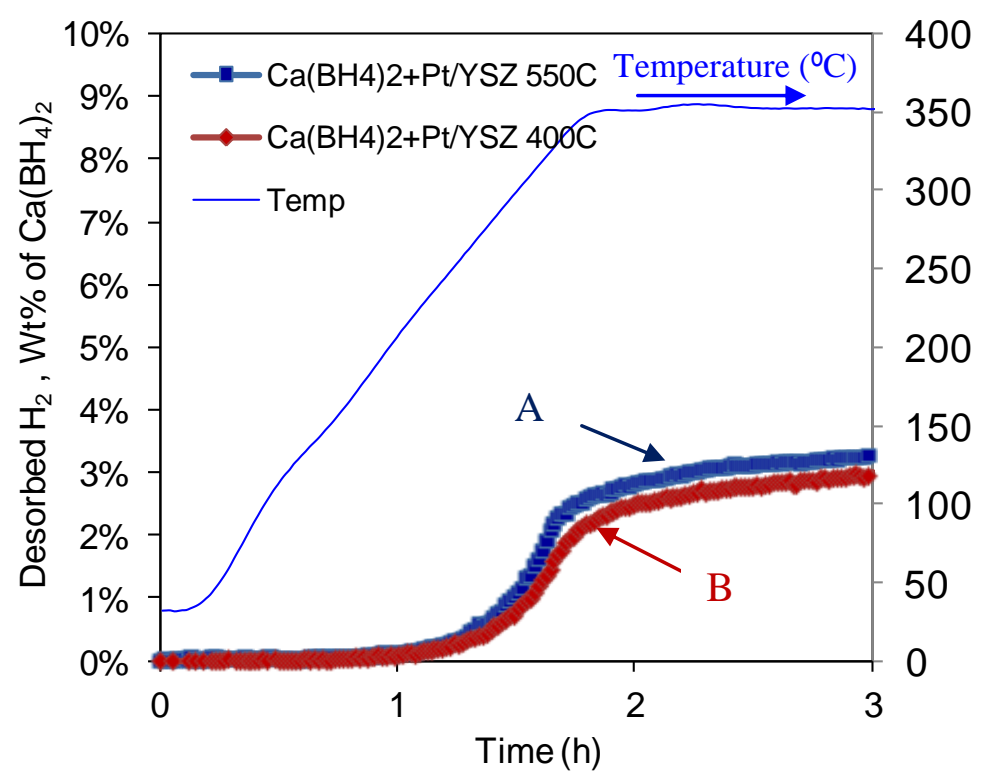

Figure 30: $2^{\text {nd }} \mathrm{H}_{2}$ desorption of

(A) $\mathrm{Ca}\left(\mathrm{BH}_{4}\right)_{2}$ SPEX milled with Pt/YSZ $550{ }^{\circ} \mathrm{C}$.

(B) $\mathrm{Ca}\left(\mathrm{BH}_{4}\right)_{2}$ SPEX milled with Pt/YSZ $400{ }^{\circ} \mathrm{C}$. 


\section{Hydride Formation in Nano-Framework Matrix}

\section{Hydride Formation in Nano-Framework Matrix}

Incorporation of borohydrides in nano-framework matrix was investigated using both solvent based infiltration and melting methods. Solvent based infiltration was found to be the most suitable method for incorporating soluble hydrides, including $\mathrm{Ca}\left(\mathrm{BH}_{4}\right)_{2}, \mathrm{Mg}\left(\mathrm{BH}_{4}\right)_{2}$ and $\mathrm{NaTi}\left(\mathrm{BH}_{4}\right)_{4}$. Hydride loading in the range of $27-52 \mathrm{wt} \%$ was achieved with $\mathrm{C}$ aerogel matrix. Only $22 \mathrm{wt} \%$ hydride loading was obtained with YSZ aerogel matrix due to the high density of framework material. TGA, DSC and DRIFTS, were used to characterize the hydride - nano framework composites. These characterization methods were also used as tools to guide the development of incorporation methods.

\section{$6.1 \mathrm{Ca}\left(\mathrm{BH}_{4}\right)_{2}$ Solvent Based Incorporation}

Liquid routes were also used to introduce calcium borohydride, $\mathrm{Ca}\left(\mathrm{BH}_{4}\right)_{2}$ into aerogel substrates. The $\mathrm{Ca}\left(\mathrm{BH}_{4}\right)_{2}$ purchased from Aldrich was not soluble in standard non-Lewis basic solvents. However, this material was soluble in Lewis basic solvents due to the coordination of the solvent to the $\mathrm{Ca}$ metal center. This reduced H-bonding and allowed for molecular species to be isolated. Therefore, Lewis basic solvents were used for the deposition of $\mathrm{Ca}\left(\mathrm{BH}_{4}\right)_{2}$.

\subsubsection{Solvated $\mathrm{Ca}\left(\mathrm{BH}_{4}\right)_{2}$ Characterization.}

The first material used was the THF-solvated $\mathrm{Ca}\left(\mathrm{BH}_{4}\right)_{2}$ adduct from Aldrich; which does not have a known structure. Only two other solvent-functionalized $\mathrm{Ca}\left(\mathrm{BH}_{4}\right)_{2}$ adducts have structural verification, those formed with either the dimethoxyethane (DME) or the diethylene glycol dimethyl ether (DGD) solvents. Both of these are monomers with two solvent molecules occupying 4 and 5 coordination sites for the DME and DGD, respectively. Of the initial investigated species, the pyridine adduct was successfully characterized and is shown in Figure 31. The pyridine derivative occupies 4 sites as in the DME but without the linked solvent nature, the solvent removal should be easier. The structure of the THF is assumed to be similar but due to the increased electron-negativity of the oxide may require additional energy for solvent dissociation.

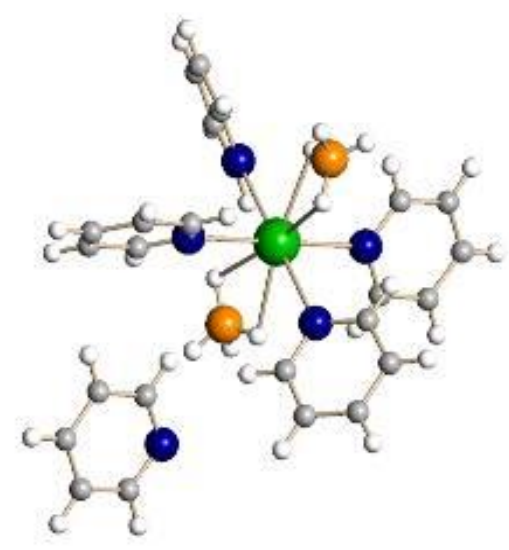

Figure 31: Structure plot of $\mathrm{Ca}\left(\mathrm{BH}_{4}\right)_{2}$ (pyridine $)_{4} *$ pyridine.

In order to determine the utility of these materials, thermal gravimetric and differential thermal analyses (TGA/DTA) were undertaken. Figure 32 (A)-(C) show the TGA/DTA obtained on the THF, 


\section{Hydride Formation in Nano-Framework Matrix}

pyridine, and DME adducts, respectively under an argon atmosphere at $5{ }^{\circ} \mathrm{C} / \mathrm{min}$ up to $600{ }^{\circ} \mathrm{C}$. As can be observed, most of the solvent was removed by $200{ }^{\circ} \mathrm{C}$ for each of the samples except the DME adduct.

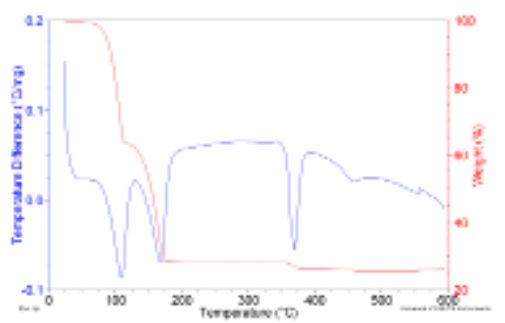

(A)

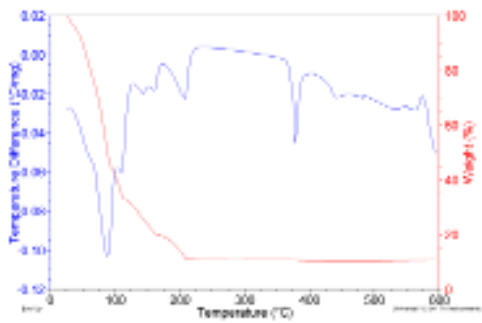

(B)

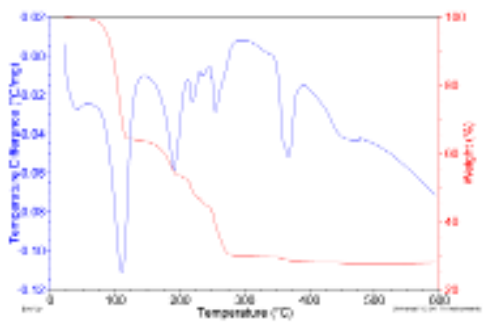

(C)

Figure 32: TGA/DTA of ground C-aerogel with $\mathrm{Ca}\left(\mathrm{BH}_{4}\right)_{2} *(\text { solvent })_{\mathrm{x}}$ : where the solvents were $(\mathrm{A})$ THF, (B) pyridine (C) DME.

\subsubsection{Aerogel Coatings}

With well-characterized precursors in hand, these materials were subsequently added to the aerogel specimens. Initial investigations focused on dip-coating the aerogel and then washing with hexane afterward to remove any unattached $\mathrm{Ca}\left(\mathrm{BH}_{4}\right)_{2}$. The FTIR and XRD data revealed no evidence of the $\mathrm{Ca}\left(\mathrm{BH}_{4}\right)_{2}$ material bound to the surface.

It was decided that the best approach was to soak and dry the solution on the aerogel samples. In addition, ground powders were chosen as the sample matrix to determine if the $\mathrm{Ca}\left(\mathrm{BH}_{4}\right)_{2}$ could be bound to a high surface area material. Based on XRD and TGA/DTA analyses, the optimal time was found to be a 48 hour soaking. The three solvated $\mathrm{Ca}\left(\mathrm{BH}_{4}\right)_{2}$ precursor adducts with THF, pyridine, and DME, were used in this process. Figure 33 shows the beryllium dome X-ray diffraction (BeD$\mathrm{XRD}$ ) patterns of ground aerogel species in comparison to the starting hydride material. As can be observed, there was no significant change observed in the major peaks. Additionally, slight broadening and variation in peak intensity implied that the environment of the compound had been altered. This indicated that the $\mathrm{Ca}\left(\mathrm{BH}_{4}\right)_{2}$ material was successfully deposited in the aerogel and exhibited some bonding interactions with the aerogel surface.

TGA/DTA analyses were made to investigate this interaction and to determine whether the solvent could be removed. Figure 34 shows the analyses of ground aerogel coated with the $\mathrm{Ca}\left(\mathrm{BH}_{4}\right)_{2}$ *solvent adducts. The thermal decompositions appeared to be identical for all materials. This suggests the solvents were removed while maintaining the reactivity of the original material. 


\section{Hydride Formation in Nano-Framework Matrix}

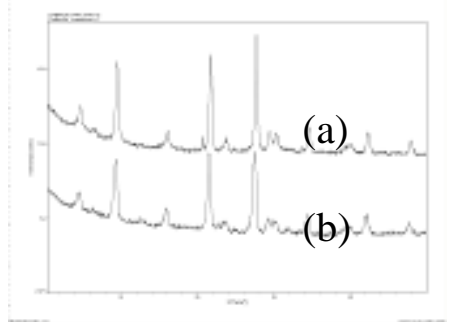

(A)

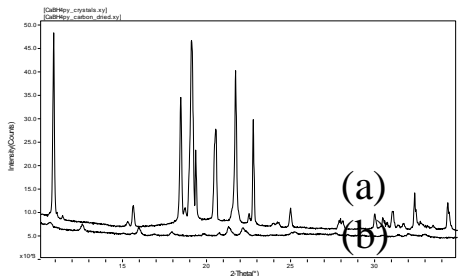

(B)

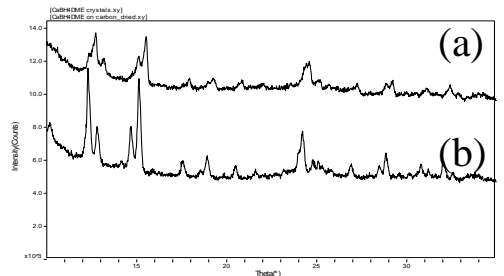

(C)

Figure 33: Beryllium dome X-ray diffraction pattern collected for (a) starting material and (b) starting material on $\mathrm{C}$-aerogel for $\mathrm{Ca}\left(\mathrm{BH}_{4}\right)_{2} *(\text { solvent })_{\mathrm{x}}$ : where the solvents were $(\mathrm{A}) \mathrm{THF},(\mathrm{B})$ pyridine, and (C) DME.

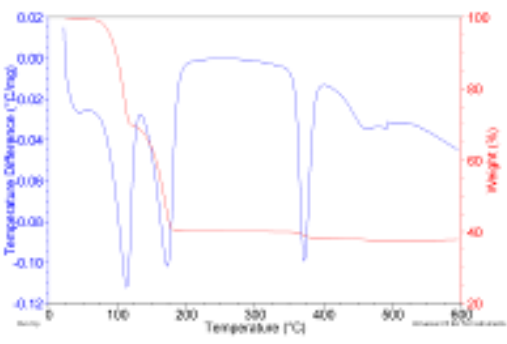

(A)

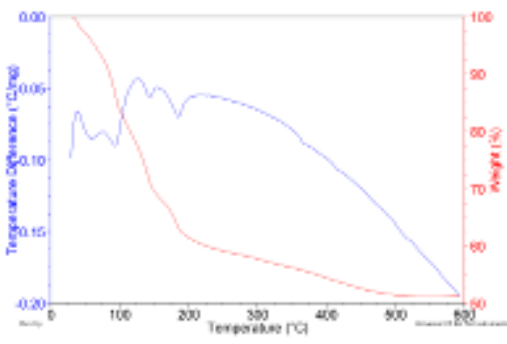

(B)

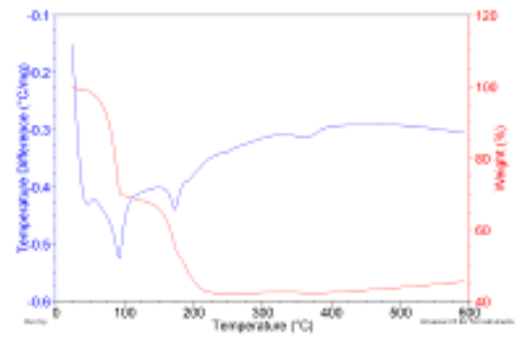

(C)

Figure 34: TGA/DTA of ground $\mathrm{C}$-aerogel with $\mathrm{Ca}\left(\mathrm{BH}_{4}\right)_{2} *(\text { solvent })_{\mathrm{x}}$ : where the solvents were $(\mathrm{A})$ THF, (B) pyridine (C) DME.

Another study on the bulk aerogels was undertaken. Again, the aerogel samples were submerged into a solution of $\mathrm{Ca}\left(\mathrm{BH}_{4}\right)_{2}$ adducts of either THF or pyridine (the DME adduct was not available). Figure 35 shows the original XRD pattern of the sample used, the pattern generated by the substrate itself, and then the coated substrate. The THF sample after coating had white powder on the surface and $\mathrm{Ca}\left(\mathrm{BH}_{4}\right)_{2} * \mathrm{THF}$ observed by XRD on the surface. For the pyridine derivative, no $\mathrm{Ca}\left(\mathrm{BH}_{4}\right)_{2} *$ pyridine material was observed.

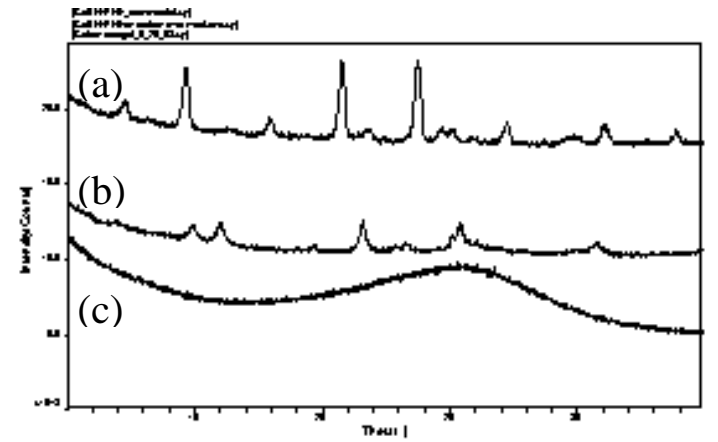

(A)

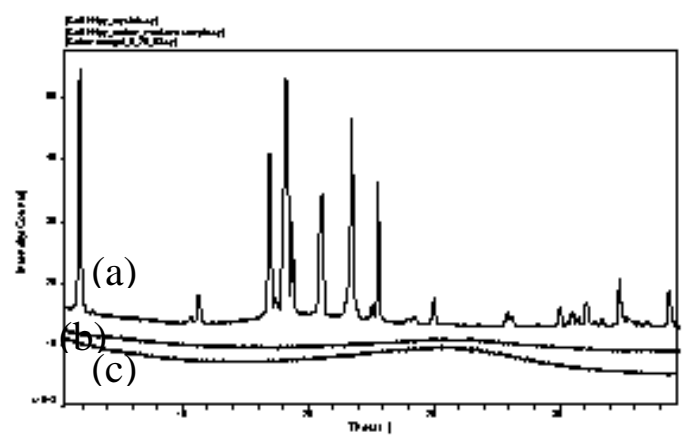

(B)

Figure 35: Beryllium dome X-ray diffraction of (a) $\mathrm{Ca}\left(\mathrm{BH}_{4}\right)_{2} *(\text { solvent })_{\mathrm{X}}$ neat and (b) coated on Caerogel, and (c) C-aerogel, for the solvents (A) THF and (B) pyridine. 


\section{Hydride Formation in Nano-Framework Matrix}

The TGA/DTA analyses of these two samples demonstrated a significant change in the decomposition of these materials. Figure 32 was the original precursor TGA/DTA spectra and Figure 36 was the $\mathrm{C}$-aerogel modified spectra.

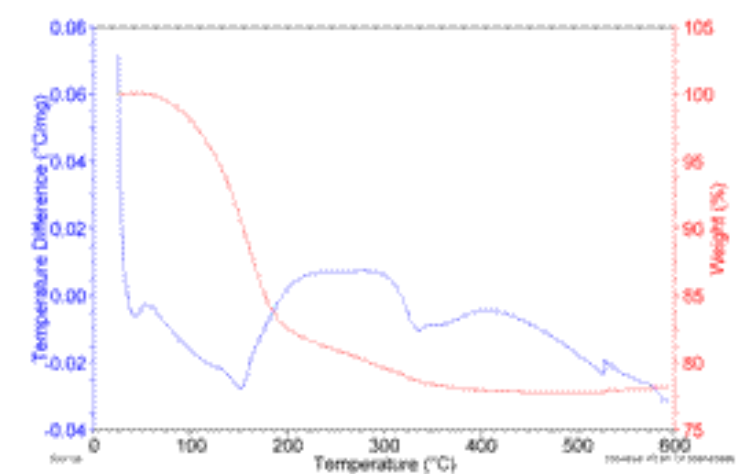

(A)

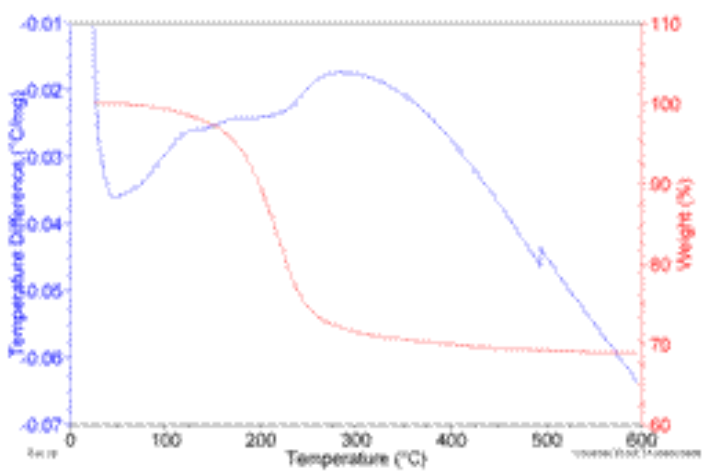

(B)

Figure 36: TGA/DTA of C-aerogel coated with $\mathrm{Ca}\left(\mathrm{BH}_{4}\right)_{2} *(\text { solvent })_{\mathrm{x}}$ : where the solvents were (A) THF and (B) pyridine.

Additional information concerning the total material added was determined by weight. Table 12 shows the mass and millimoles of sample added to the various matrices. As can be observed, the THF adduct appears to be the most bound but this sample did have a white powder that was visible on the surface, whereas the remainder were black (i.e., the color of the original aerogel). Therefore, the higher loading may not be bound material but more representative of a dried-on material.

Table 12: Weight variations for the select coated samples listed

\begin{tabular}{|c|c|c|c|c|c|}
\hline Method & Solvent & Matrix & $\begin{array}{c}\text { Wt of matrix } \\
(\mathrm{g})\end{array}$ & $\begin{array}{c}\text { Wt of hydride } \\
(\mathrm{g})\end{array}$ & mmol of hydride \\
\hline Dip coat & pyridine & $\begin{array}{c}\text { Ground } \\
\text { carbon }\end{array}$ & 0.042 & 0.004 & 0.0103 \\
\hline $\begin{array}{c}\text { Aerogel } \\
48 \text { hours }\end{array}$ & THF & Carbon & 0.12 & 0.099 & 0.463 \\
\hline $\begin{array}{c}\text { Aerogel } \\
48 \text { hours }\end{array}$ & pyridine & Carbon & 0.056 & 0.01 & 0.0258 \\
\hline
\end{tabular}

Subsequent loading studies therefore focused on the THF adduct. Two substrates were chosen to determine loading capacity on the YSZ and $\mathrm{C}$ aerogels. For initial testing, $\mathrm{Ca}\left(\mathrm{BH}_{4}\right)_{2} *(\mathrm{THF})_{2}$ was dissolved in THF to form a $\sim 0.3 \mathrm{M}$ solution. The $\mathrm{C}$ aerogel samples were modified by this solution through: a) rapid dip coating, b) saturated soaking for 48 hours and c) heating in solution. The samples were removed and allowed to dry under an argon atmosphere in a glovebox. BeD-XRD and weight variations were used to determine if $\mathrm{Ca}\left(\mathrm{BH}_{4}\right)_{2} *(\mathrm{THF})_{2}$ was incorporated into the substrate. The BeD-XRD data was collected and found to yield little insight into the inclusion of 


\section{Hydride Formation in Nano-Framework Matrix}

$\mathrm{Ca}\left(\mathrm{BH}_{4}\right)_{2} *(\mathrm{THF})_{2}$. This is most likely due to the fact that XRD is a surface technique which lends little insight into the porosity of the material. Weight data implied the coated $\mathrm{C}$ aerogel was gaining weight, while the YSZ results were difficult to interpret since both the powder and the YSZ were white.

The method for loading was then changed from dip-coating to an incipient wetness method, wherein the amount of solution added was directly related to the porosity of the final material. Table 13 shows the data associated with the results. Based on the pore volume in the $\mathrm{C}$ aerogel, a solution of $\mathrm{Ca}\left(\mathrm{BH}_{4}\right)_{2} *(\mathrm{THF})_{2}$ in $\mathrm{THF}$ was added to the $\mathrm{C}$ aerogel. Upon addition, the entire solution was absorbed by the aerogel, leaving a dry wafer. This suggests that the precursor was completely incorporated into the pores. This was done for $2 \mathrm{YSZ}$ and $1 \mathrm{C}$ aerogel substrates (see Table 4). One YSZ sample was saturated and the other, the incipient wetness based on the porosity, was attempted. Table 14 lists the calculated values and observed phases. Baseline determination of the inclusion and properties of the THF adduct was determined using TGA-MS. The analysis results indicated that there was $\mathrm{H}_{2}$ desorbed from sample, however the amount is very low. Modification to the procedure is needed to increase hydride loading.

Table 13: Summary of $\mathrm{Ca}\left(\mathrm{BH}_{4}\right)_{2}$ Loading

\begin{tabular}{|l|l|l|l|l|l|}
\hline \multicolumn{1}{|c|}{ Substrate } & $\begin{array}{c}\text { Substrate } \\
\text { Porosity }\end{array}$ & \multicolumn{1}{|c|}{ Molarity } & $\begin{array}{c}\text { BeD-XRD } \\
\text { Phase }\end{array}$ & $\begin{array}{c}\text { Weight } \\
\text { Change }\end{array}$ & $\begin{array}{c}\text { Calc'd } \\
\text { Loading }\end{array}$ \\
\hline YSZ -1 & $0.72 \mathrm{~mL} / \mathrm{g}$ & $0.16 \mathrm{~g} / \mathrm{cc}$ & St. Mat & $0.09 \mathrm{~g}$ & $4 \%$ \\
\hline YSZ -2 & 0.72 & Conc. & St. Mat & $0.10 \mathrm{~g}$ & $10 \%$ \\
\hline $\mathrm{C}$ & 3.67 & 0.21 & St. Mat & $0.10 \mathrm{~g}$ & $14 \%$ \\
\hline
\end{tabular}

\subsubsection{Incipient Wetness Incorporation in $\mathrm{C}$ aerogel}

Modification of incipient wetness approach was applied to obtain higher loadings in the $\mathrm{C}(\mathrm{PI})$ aerogel. Calculations based on the pore volume of the aerogel indicated that even higher loadings were possible. Therefore, efforts focused on super-saturating the $\mathrm{C}(\mathrm{PI})$ aerogel $(0.345 \mathrm{~g})$ with a very concentrated solution of $\mathrm{Ca}\left(\mathrm{BH}_{4}\right)_{2} *(\mathrm{THF})_{2}$ in $\mathrm{THF}(2.5 \mathrm{~g}$ in $3 \mathrm{~mL})$. After the monolithic aerogel wafer was soaked in the solution, it was dried under vacuum at $100{ }^{\circ} \mathrm{C}$ for 2 hours to remove the solvent. The results estimated from solubility calculations suggest that the amount of $\mathrm{Ca}\left(\mathrm{BH}_{4}\right)_{2}$ incorporated was nominally $50 \mathrm{wt} \%$. Using this estimated hydride mass, the desorption capacity was apparently low, as described above (see Figure 42).

In order to confirm the amount of $\mathrm{Ca}\left(\mathrm{BH}_{4}\right)_{2}$ incorporated, additional samples were made and evaluated through weight determination of the aerogel before and after incorporation. A sample was prepared by using $0.76 \mathrm{~g}$ of $\mathrm{C}(\mathrm{PI})$ aerogel and $3.5 \mathrm{~g}$ of $\mathrm{Ca}\left(\mathrm{BH}_{4}\right) * \mathrm{THF}$ in $4.5 \mathrm{~mL}$ of THF. The sample was heated to $100{ }^{\circ} \mathrm{C}$ under vacuum for 2 hours and the final total weight of aerogel and incorporated

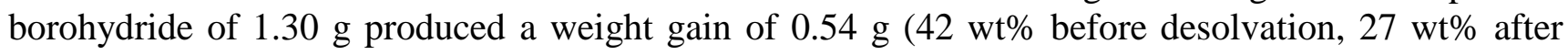
desolvation ). The testing results of this sample are reported in section 7.1.

Incorporation of $\mathrm{Ca}\left(\mathrm{BH}_{4}\right)_{2}$ in $\mathrm{C}(\mathrm{PF})$ aerogel was subsequently conducted using incipient wetness method, with precise sample weight measurement for loading determination. Two infiltration steps were employed to increase hydride loading. After infiltration, the sample was heated at $60{ }^{\circ} \mathrm{C}$ in an $\mathrm{Ar}$ 


\section{Hydride Formation in Nano-Framework Matrix}

glove box for 12 hours, followed by desolvaton at $150{ }^{\circ} \mathrm{C}$ in vacuum for 2 hours, and $160{ }^{\circ} \mathrm{C}$ with 60 bar of $\mathrm{H}_{2}$ for 24 hours. The result was $39 \mathrm{wt} \%$ of $\mathrm{Ca}\left(\mathrm{BH}_{4}\right)_{2}$ incorporated in $\mathrm{C}(\mathrm{PF})$ aerogel.

\subsubsection{Incorporation of $\mathrm{Ca}\left(\mathrm{BH}_{4}\right)_{2}$ in Pt-Catalyzed $\mathrm{ZrO}_{2}$ Aerogel}

$\mathrm{Ca}\left(\mathrm{BH}_{4}\right)_{2}$ was also incorporated in Pt-catalyzed YSZ aerogel by incipient wetness impregnation method. A $3.36 \mathrm{M} \mathrm{Ca}\left(\mathrm{BH}_{4}\right)_{2}$ solution was prepared by dissolving $3.6 \mathrm{~g}$ of $\mathrm{Ca}\left(\mathrm{BH}_{4}\right)_{2} * 2 \mathrm{THF}$ in $5 \mathrm{~mL}$ of THF solution at $55-60{ }^{\circ} \mathrm{C}$. $1.5-1.7 \mathrm{~mL}$ aliquots of the solution was added to $5 \mathrm{~g}$ of Pt-catalyzed YSZ aerogels for infiltration, followed by solvent evaporation at $60{ }^{\circ} \mathrm{C}$ for $30 \mathrm{~min}$. The infiltration was repeated for three times to increase hydride loading. The infiltrated sample was then heated at 50 ${ }^{\circ} \mathrm{C}$ in an Ar glove box for 12 hours, followed by desolvaton at $150{ }^{\circ} \mathrm{C}$ in vacuum for 2 hours and 160 ${ }^{\circ} \mathrm{C}$ with 60 bar of $\mathrm{H}_{2}$ for 24 hours. The $\mathrm{Ca}\left(\mathrm{BH}_{4}\right)_{2}$ loading was $22.25 \mathrm{wt} \%$. The incorporated material was then SPEX milled for 15 min to form homogenous powder for $\mathrm{H}_{2}$ desorption /absorption testing.

\subsection{Incorporation of $\mathrm{Mg}\left(\mathrm{BH}_{4}\right)_{2}$ in $\mathrm{C}(\mathrm{PF})$ Aerogel}

Incorporation of $\mathrm{Mg}\left(\mathrm{BH}_{4}\right)_{2}$ in the $\mathrm{C}(\mathrm{PF})$ aerogel was conducted by the same method used in the incorporation of $\mathrm{Ca}\left(\mathrm{BH}_{4}\right)_{2}$. Approximately $1 \mathrm{~g}$ of $\mathrm{C}$ aerogel was submerged in $\mathrm{Mg}\left(\mathrm{BH}_{4}\right)_{2}$ etherate solution provided by OSU. The solution was prepared by reacting $\mathrm{Na}\left(\mathrm{BH}_{4}\right)_{2}$ with $\mathrm{MgCl}_{2}$ in diethyl ether. The $\mathrm{Mg}\left(\mathrm{BH}_{4}\right)_{2}$ solution obtained was further concentrated by solvent evaporation. The incorporated material was dried at $80{ }^{\circ} \mathrm{C}$ inside a glove box overnight and followed by desolvation under various desolvating conditions (see Section 7.5). The loading of $\mathrm{Mg}\left(\mathrm{BH}_{4}\right)_{2}$ in the $\mathrm{C}(\mathrm{PF})$ aerogel was $52 \mathrm{wt} \%$.

\subsection{Solvent Based Incorporation of $\mathrm{NaTi}\left(\mathrm{BH}_{4}\right)_{4} * \mathrm{DME}$}

From work in previous contract DE-FC36-04GO14012, $\mathrm{NaTi}\left(\mathrm{BH}_{4}\right)_{4} * \mathrm{DME}(\mathrm{DME}=$ dimethoxyethane) was shown to be thermally unstable, decomposing from bright blue to gray to eventually black over a few days at room temperature. In order to gauge the effects of an inorganic metal oxide support on the stability of this complex, we have begun a study using commercially available silica gel. The thermal stability, $\mathrm{H}_{2}$ discharge, and re-adsorption properties of the resulting materials were examined. Silica gel with high surface area was chosen for the initial experiments. Two different calcination temperatures were applied to these supports. The physical properties of these materials are shown below:

Table 14: Physical Properties of Silica Nano-Framework Materials

\begin{tabular}{|c|c|c|c|c|c|c|}
\hline $\begin{array}{c}\text { Silica } \\
\text { Type }\end{array}$ & $\begin{array}{c}\text { Calcine } \\
\mathrm{T} \\
\left({ }^{\circ} \mathrm{C}\right)\end{array}$ & $\begin{array}{c}\text { Surface } \\
\text { Area } \\
\left(\mathrm{m}^{2} / \mathrm{g}\right)\end{array}$ & $\begin{array}{c}\text { Pore } \\
\text { Volume } \\
(\mathrm{cc} / \mathrm{g})\end{array}$ & $\begin{array}{c}\text { Bulk Density } \\
(\mathrm{g} / \mathrm{ml})\end{array}$ & $\begin{array}{c}\text { Particle Size } \\
(\mathrm{um})(\%)\end{array}$ & $\begin{array}{c}\text { OH group } \\
(\mathrm{mmol} / \mathrm{g})\end{array}$ \\
\hline $\begin{array}{c}\text { Grace } \\
948\end{array}$ & 200 & 276 & 1.60 & $\begin{array}{c}\text { not available but } \\
\text { around } 0.27\end{array}$ & Ave. 53.3 & 3.2 \\
\hline $\begin{array}{c}\text { Ineos ES- } \\
70\end{array}$ & 600 & 312 & 1.58 & 0.27 & Ave. 38.6 & 0.78 \\
\hline
\end{tabular}




\section{Hydride Formation in Nano-Framework Matrix}

Four supported materials were prepared by the incipient wetness method. Two different loadings of the active component were tested on each type of silica gel. A summary of the loadings used can be found in the Table 15 .

Table 15: Summary of hydride loading

\begin{tabular}{|c|c|c|c|c|c|c|}
\hline Silica & Loading & $\begin{array}{c}\text { Ti-3 } \\
(\mathrm{g})\end{array}$ & $\begin{array}{c}\text { DME } \\
(\mathrm{g})\end{array}$ & $\begin{array}{c}\text { Silica } \\
(\mathrm{g})\end{array}$ & $\begin{array}{c}\text { Ti-1 loading } \\
(\%)\end{array}$ & $\begin{array}{c}\text { Ti loading } \\
(\mathrm{mmol} / \mathrm{g})\end{array}$ \\
\hline Grace & High & 2 & 1 & 2 & 33.5 & 1.52 \\
\hline Grace & Low & 2 & $2($ ether $)$ & 3 & 25.8 & 1.17 \\
\hline Ineos & High & 2 & 1 & 2 & 33.5 & 1.52 \\
\hline Ineos & Low & 2 & 2.16 & 3 & 25.8 & 1.17 \\
\hline
\end{tabular}

A number of observations were made from these preparations: In all four cases, the final supported materials appeared to contain $\mathrm{NaTi}\left(\mathrm{BH}_{4}\right)_{4} * \mathrm{DME}$ (Ti-1) based on the mass of the isolated solid. The color of the complex (bright blue) remained unchanged after deposition on silica except perhaps lighter due to dilution by the silica. The supported materials were still thermally unstable at room temperature. However, the rate of decomposition (qualitatively based on color change) slowed considerably by an order of magnitude. The low loaded materials were more stable than the high ones. The DSC and TGA-DSC plots of these materials are shown in Figure 37 to Figure 39. Several observations can also be made based on the data. The degree of the exotherm observed in the DSC traces is roughly proportional to the loading of the titanium complex (see Figure 37 and

Figure 38). In contrast to unsupported Ti-1, no initial endotherm was observed in the DSC. Unlike the closed cell DSC result, the DSC from the open cell TGA-DSC of all four materials show only a very small endotherm and no exothermic events. The TGA, being an open system, allows the volatile DME to escape. The large exotherm in the closed cell DSC is apparently related to DME. The TGA of all four materials showed weight losses of only 4-6\%, regardless of loading. This likely indicated that the DME was absent while the TGA was conducted.

The DRIFTS spectrometer was set up to record the IR spectra of these solid materials. The DRIFTS spectra of freshly prepared materials (bright blue in color) are shown in Figure 40. The absorbance areas for the $\mathrm{C}-\mathrm{H}\left(2700-3100 \mathrm{~cm}^{-1}\right)$ and $\mathrm{B}-\mathrm{H}\left(2000-2500 \mathrm{~cm}^{-1}\right)$ frequencies are consistent with the number of DME molecules (Ti-1 or Ti-3) in the complex, as well as the loading. 


\section{Hydride Formation in Nano-Framework Matrix}

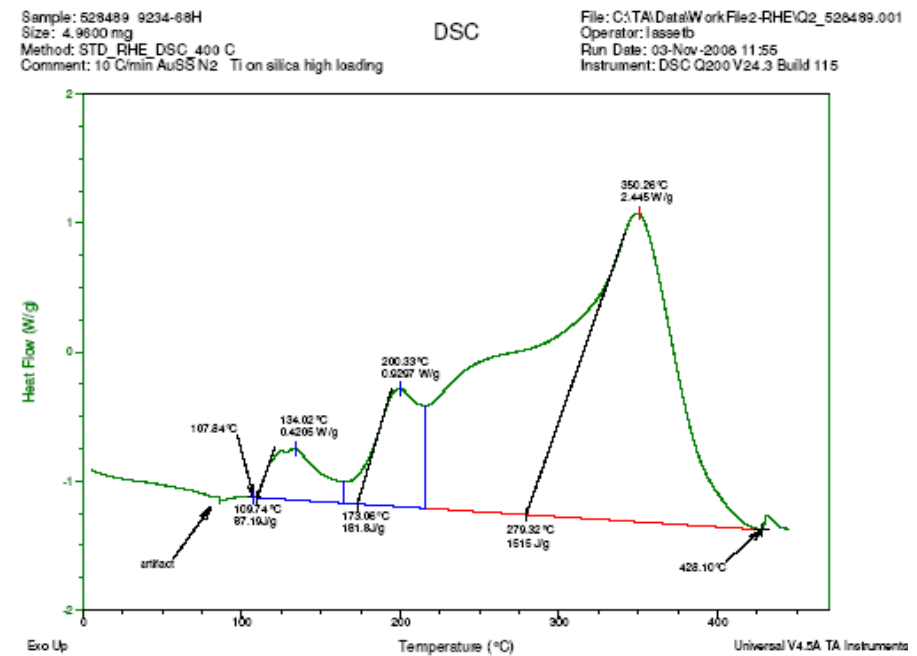

Figure 37: DSC of Ti-1 supported on Ineos ES-70, high loading.

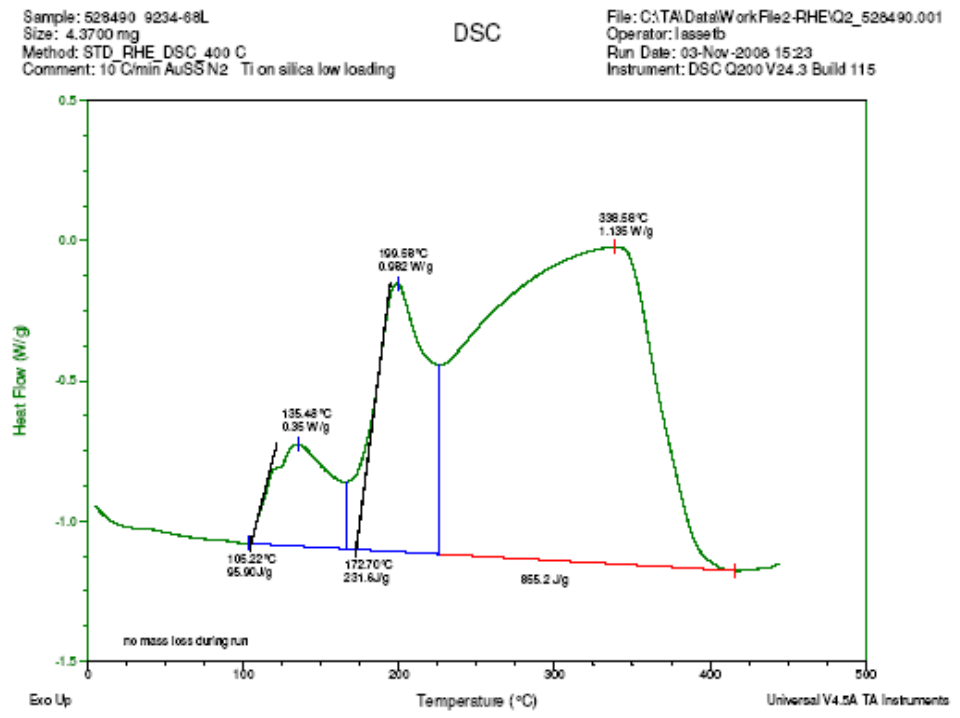

Figure 38: DSC of Ti-1 supported on Ineos ES-70, low loading. 


\section{Hydride Formation in Nano-Framework Matrix}

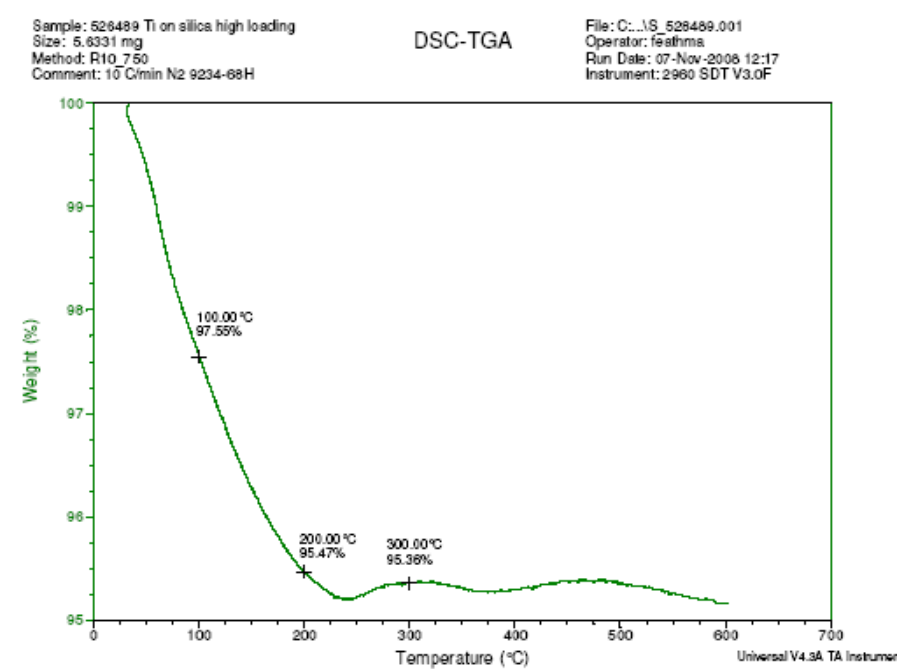

Figure 39: TGA of Ti-1 supported on Ineos ES-70, high loading.

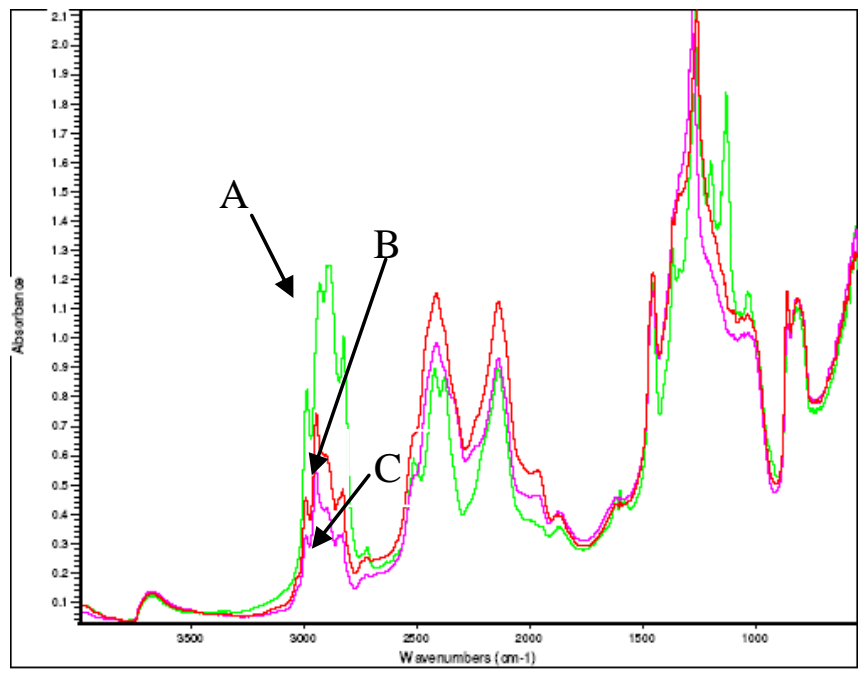

Figure 40: Overlay DRIFTS of $\mathrm{NaTi}\left(\mathrm{BH}_{4}\right)_{4}$ complexes supported on Ineos silica From top to bottom (according to the $3000 \mathrm{~cm}^{-1}$ frequency)
(A) Ti-3 on Ineos silica low loading.
(B) Ti-1 on Ineos silica high loading.
(C) Ti-1 on Ineos silica low loading.

\section{$6.4 \mathrm{Ca}\left(\mathrm{BH}_{4}\right)_{2}$ Melt Incorporation}

The initial incorporation of $\mathrm{Ca}\left(\mathrm{BH}_{4}\right)_{2}$ was conducted with a small-pore-sized $\mathrm{C}$ aerogel obtained from HRL by melt processing under $\mathrm{H}_{2}$ pressure to avoid decomposition. Calcium borohydride was obtained by desolvating Aldrich $\mathrm{Ca}\left(\mathrm{BH}_{4}\right)_{2}$ at $c a .150{ }^{\circ} \mathrm{C}$ over a few hours, resulting in a mixture of 


\section{Hydride Formation in Nano-Framework Matrix}

alpha and beta polymorphs. Carbon aerogel was obtained from HRL (John Vajo) in the form of nominally $5 \times 3 \mathrm{~mm}$ sized cubes. The $\mathrm{C}$ aerogel cubes were covered with $\mathrm{Ca}\left(\mathrm{BH}_{4}\right)_{2}$ powder and placed in a commercial autoclave for further treatment at SNL's high-pressure station. The sample was heated to $560{ }^{\circ} \mathrm{C}$ under $10,000 \mathrm{psi} \mathrm{H}_{2}$ pressure for 24 hours. After treatment, the sample looked like it had melted and covered the surfaces of the $\mathrm{C}$-aerogel. Moreover, the $\mathrm{C}$ aerogel had crumbled which may have indicated that a reaction, rather than incorporation, has taken place. The product was analyzed with the Simultaneous Thermo-gravimetric Modulated-Beam Mass Spectrometer (STMBMS) to obtain information on desorption temperatures and what species were coming off during heating up to $600{ }^{\circ} \mathrm{C}$ of the $\mathrm{C}$ aerogel sample as-is and with potentially incorporated $\mathrm{Ca}\left(\mathrm{BH}_{4}\right)_{2}$. The STMBMS analysis of the $\mathrm{C}$ aerogel showed a small amount of water coming off, even after heat treatment at $150^{\circ} \mathrm{C}($

Figure 41). It is noteworthy that a sample of $\mathrm{Ca}\left(\mathrm{BH}_{4}\right)_{2}-\mathrm{C}$ aerogel does not show significant peaks from potential species $\mathrm{BH}_{3}$ and $\mathrm{B}_{2} \mathrm{H}_{6}$, as was detected in a sample of $\mathrm{Ca}\left(\mathrm{BH}_{4}\right)_{2}$ as is. Moreover, the $\mathrm{H}_{2}$ release shows a different mechanism upon comparing a sample of $\mathrm{Ca}\left(\mathrm{BH}_{4}\right)_{2}$ with $\mathrm{C}$-aerogel and $\mathrm{Ca}\left(\mathrm{BH}_{4}\right)_{2}$ as is. In Figure 41, it is noted that $\mathrm{H}_{2}$ starts to evolve from the sample starting at $\sim 275{ }^{\circ} \mathrm{C}$ and peaks at $\sim 370{ }^{\circ} \mathrm{C}$. The dip observed at $370{ }^{\circ} \mathrm{C}$ may arise from the $\mathrm{H}_{2}$ signal saturating the detector counting system, which leads to an observed lowering of the count rates. Starting at about $200{ }^{\circ} \mathrm{C}$ a very small signal that may be associated with $\mathrm{BH}_{3}(\mathrm{~m} / \mathrm{z}=13)$ starts to evolve. Another very small signal at $\mathrm{m} / \mathrm{z}=55$ may arise from $\mathrm{CaBH}_{4}$. These data show that the number and amount of species that evolve from the $\mathrm{Ca}\left(\mathrm{BH}_{4}\right)_{2}$ in the $\mathrm{C}$ aerogel is much less than observed for either the $\mathrm{Ca}\left(\mathrm{BH}_{4}\right)_{2}$ or the Ti modified $\mathrm{Ca}\left(\mathrm{BH}_{4}\right)_{2}$.

The following is a comparison of the $\mathrm{H}_{2}$ evolution from the uncatalyzed (black), Ti catalyzed (blue), and $\mathrm{Ca}\left(\mathrm{BH}_{4}\right)_{2}$ in the $\mathrm{C}$ aerogel (red). The following differences may be worth noting in the evolution of $\mathrm{H}_{2}$ from the three samples. The evolution of $\mathrm{H}_{2}$ below $300{ }^{\circ} \mathrm{C}$ is near zero in the $\mathrm{Ca}\left(\mathrm{BH}_{4}\right)_{2}$ in the $\mathrm{C}$ aerogel, whereas it is a significant signal in both the uncatalyzed and Ti-catalyzed samples. The rates of release of hydrogen in the main $\mathrm{H}_{2}$ evolution region $\left(320\right.$ to $\left.340{ }^{\circ} \mathrm{C}\right)$ are similar for the catalyzed aerogel $\mathrm{Ca}\left(\mathrm{BH}_{4}\right)_{2}$ samples and more abrupt for the uncatalyzed $\mathrm{Ca}\left(\mathrm{BH}_{4}\right)_{2}$ sample. The second main $\mathrm{H}_{2}$ evolution peak occurs between 400 and $500{ }^{\circ} \mathrm{C}$ in the uncatalyzed and catalyzed $\mathrm{Ca}\left(\mathrm{BH}_{4}\right)_{2}$ samples. In the $\mathrm{Ca}\left(\mathrm{BH}_{4}\right)_{2}$ aerogel sample the $\mathrm{H}_{2}$ continues to evolve over a much higher temperature range (400 to $580{ }^{\circ} \mathrm{C}$ ). This indicated that the decomposition of $\mathrm{Ca}\left(\mathrm{BH}_{4}\right)_{2}$ in the $\mathrm{C}$ aerogel created a more stable hydride.

An attempt was made to incorporate $\mathrm{Ca}\left(\mathrm{BH}_{4}\right)_{2}$ into functionalized $\mathrm{C}$ and $\mathrm{YSZ}$ aerogels. It was observed that if the $\mathrm{C}$ aerogel was in the form of a powder, instead of in a cube, no indication of incorporation was visible after heat treatment under high $-\mathrm{H}_{2}$ pressures. The oxide material was in the form of a powder and was mixed with $\mathrm{Ca}\left(\mathrm{BH}_{4}\right)_{2}$ followed by heat treatment at the above conditions. Thereafter, the sample was analyzed by XRD, but no peaks from $\mathrm{Ca}\left(\mathrm{BH}_{4}\right)_{2}$ were observed which currently cannot be explained. 


\section{Hydride Formation in Nano-Framework Matrix}

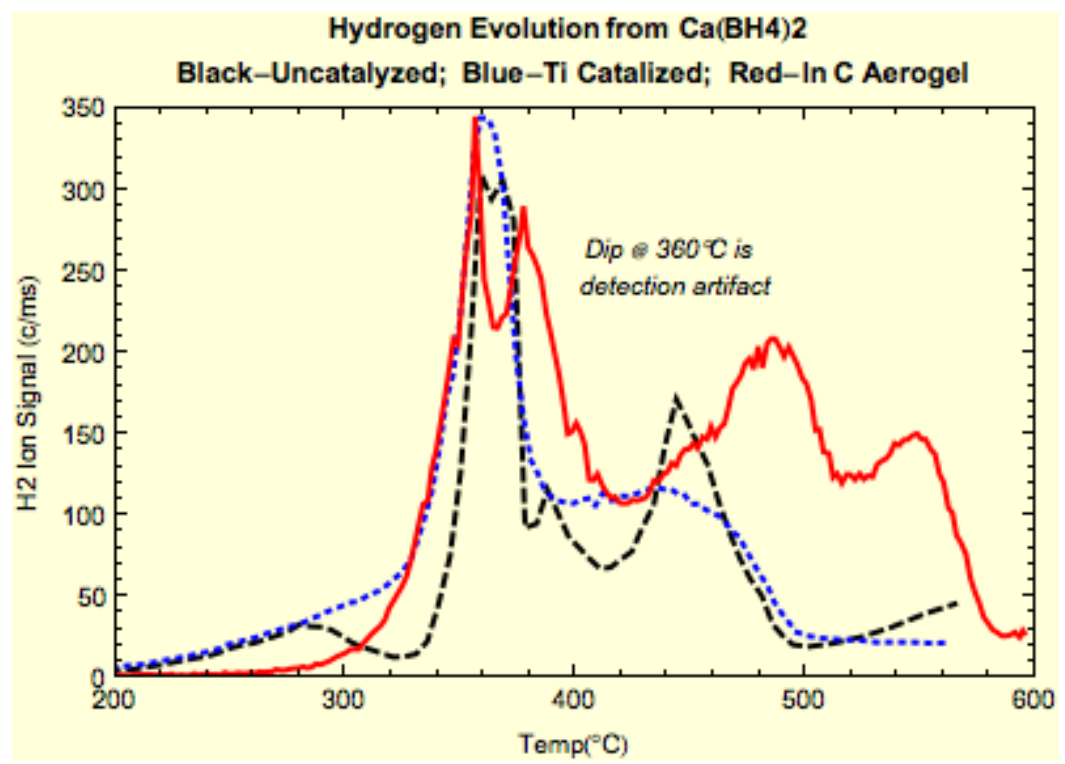

Figure 41: A plot from STMBMS comparing $\mathrm{H}_{2}$ evolution of $\mathrm{Ca}\left(\mathrm{BH}_{4}\right)_{2}-\mathrm{C}$-aerogel (red) with $\mathrm{Ca}\left(\mathrm{BH}_{4}\right)_{2}$ (black) and $\mathrm{Ca}(\mathrm{BH} 4) 2-$ dopant (blue).

Bulk incorporation of $\mathrm{Ca}\left(\mathrm{BH}_{4}\right)_{2}$ into the $\mathrm{C}(\mathrm{PI})$ aerogel was explored via melting under high $\mathrm{H}_{2}$ pressure and temperature. Control experiments were done in order to assess the stability of both the $\mathrm{C}$ aerogel and $\mathrm{Ca}\left(\mathrm{BH}_{4}\right)_{2}$ under these conditions $\left(560^{\circ} \mathrm{C}\right.$ and $\left.10,000 \mathrm{psi} \mathrm{H}_{2}\right)$. BET measurements of the $\mathrm{C}$ aerogel gave a surface area of approximately $400 \mathrm{~m}^{2} / \mathrm{g}$. This material was then subjected to $10,000 \mathrm{psi}$ of $\mathrm{H}_{2}$ at $560{ }^{\circ} \mathrm{C}$ for 18 hours. The measured BET surface area came in at $700 \mathrm{~m}^{2} / \mathrm{g}$, indicating that the porous structure had not collapsed. Why the surface area of the $\mathrm{C}$ aerogel treated at $560{ }^{\circ} \mathrm{C}$ and $10,000 \mathrm{psi}_{2}$ is higher than the untreated aerogel is unknown. Similarly, $\mathrm{Ca}\left(\mathrm{BH}_{4}\right)_{2}$ was heated to 560 ${ }^{\circ} \mathrm{C}$ under 10,000 psi of $\mathrm{H}_{2}$ for 18 hours. The powdered material appeared to have sintered, forming a larger bulk phase. Preliminary powder X-ray diffraction showed $\alpha$-phase $\mathrm{Ca}\left(\mathrm{BH}_{4}\right)_{2}$ with some amorphous material.

When a sample of $\mathrm{Ca}\left(\mathrm{BH}_{4}\right)_{2}$ and $\mathrm{C}$ aerogel was heated to $560{ }^{\circ} \mathrm{C}$ under 10,000 psi of $\mathrm{H}_{2}$, it appeared that $\mathrm{Ca}\left(\mathrm{BH}_{4}\right)_{2}$ wetted the surface of the aerogel. The change in mass for the carbon aerogel was low suggesting only minimal incorporation of $\mathrm{Ca}\left(\mathrm{BH}_{4}\right)_{2}$ within the pores. BET measurements showed a significant decrease in pore volume after the heating step with $\mathrm{Ca}\left(\mathrm{BH}_{4}\right)_{2}$ from 400 to $2 \mathrm{~m}^{2} / \mathrm{g}$. The pore volume decreased from 2.5 to $0.02 \mathrm{~cm}^{3} / \mathrm{g}$. It is unclear how such a large reduction in pore size could be achieved with only a small wt\% increase attributed to $\mathrm{Ca}\left(\mathrm{BH}_{4}\right)_{2}$ infiltration.

The inability to achieve high sample loadings plus the ambiguous results of BET measurement have led SNL to down select solid-state methods for incorporating $\mathrm{Ca}\left(\mathrm{BH}_{4}\right)_{2}$ into the $\mathrm{C}$ aerogel samples. Furthermore, due to the lack of a kinetic effect on the release of $\mathrm{H}_{2}$ from hybrid materials prepared via melt-incorporation, further investigations were terminated. 


\section{Hydride - Framework Composite Testing}

\section{Hydride - Framework Composite Testing}

This section describes experimental testing of $\mathrm{H}_{2}$ storage and other properties of hydride - framework composites. The composites were cycled in Sievert's apparatus to measure $\mathrm{H}_{2}$ desorption kinetics and absorption capacity. Improvements in $\mathrm{H}_{2}$ desorption kinetics were observed in hydride - framework composites for all stable hydrides $\left(\mathrm{Ca}\left(\mathrm{BH}_{4}\right)_{2}\right.$ and $\left.\mathrm{Mg}\left(\mathrm{BH}_{4}\right)_{2}\right)$. $\mathrm{Ca}\left(\mathrm{BH}_{4}\right)_{2}-\mathrm{C}$ (both PI and PF) composites showed most significant kinetics enhancement. The on-set temperature for $\mathrm{H}_{2}$ desorption was decreased by more than $50^{\circ} \mathrm{C}$. However, no improvements in $\mathrm{H}_{2}$ absorption capacity were detected in these composites. Solid state NMR analysis of the cycled samples showed the formation of stable intermediate, alkaline earth $\mathrm{B}_{12} \mathrm{H}_{12}$. This stable intermediate hinders complete rehydrogenation of $\mathrm{Ca}\left(\mathrm{BH}_{4}\right)_{2}$ and $\mathrm{Mg}\left(\mathrm{BH}_{4}\right)_{2}$, resulting decreased reversibility. The stability of unstable $\mathrm{NaTi}\left(\mathrm{BH}_{4}\right)_{4}$ was improved significantly through incorporation into $\mathrm{SiO}_{2}$ aerogel. Although this compound was still not stable enough for practical application, this result demonstrated that unstable hydride can be stabilized through chemical interaction with framework surface. $\mathrm{N}_{2}$ porosimetry and SEM analysis of the $\mathrm{Ca}\left(\mathrm{BH}_{4}\right)_{2}-\mathrm{C}$ (PI) composites was conducted to analyze framework surface area, pore sizes and pore volume after incorporation. Within these monolithic $\mathrm{C}$ aerogel, large pores were preferentially infiltrated by the hydride solutions during incorporation.

\subsection{Evaluation of $\mathrm{Ca}\left(\mathrm{BH}_{4}\right)_{2}$ Incorporated in $\mathrm{C}(\mathrm{PI})$ Aerogel}

$\mathrm{Ca}\left(\mathrm{BH}_{4}\right)_{2}$ was incorporated in $\mathrm{C}(\mathrm{PI})$ aerogel with the solvent based procedure described in Section 6.1.3. The first batch of incipient wetness incorporated $\mathrm{Ca}\left(\mathrm{BH}_{4}\right)_{2}-\mathrm{C}(\mathrm{PI})$ material was desolvated at $160{ }^{\circ} \mathrm{C}$ under vacuum for 24 hours. The loading level of $\mathrm{Ca}\left(\mathrm{BH}_{4}\right)_{2}$ was estimated to be $50 \mathrm{wt} \%$. BET analyses of the sample before and after incorporation / desolvation are shown in Table 16. There are significant reductions in surface area, pore size, and pore volume after incorporation. The pore volume was reduced to $43 \%$ of the original value. It is apparent that additional $\mathrm{Ca}\left(\mathrm{BH}_{4}\right)_{2}$ can be incorporated by repeating the incorporation procedure to achieve higher hydride loading.

Table 16: $\mathrm{BET}$ analysis of $\mathrm{Ca}\left(\mathrm{BH}_{4}\right)_{2}-\mathrm{C}(\mathrm{PI})$ composite.

\begin{tabular}{|c|c|c|c|}
\hline NFS Material & $\begin{array}{c}\text { Surface Area } \\
\mathbf{m}^{\mathbf{2}} / \mathbf{g}\end{array}$ & $\begin{array}{c}\text { Avg. Pore Size } \\
\mathbf{n m}\end{array}$ & $\begin{array}{c}\text { Pore volume } \\
\mathbf{c c} / \mathbf{g}\end{array}$ \\
\hline Carbon Aerogel (PI) & 580 & 25 & 3.7 \\
\hline $\begin{array}{l}\mathrm{Ca}\left(\mathrm{BH}_{4}\right)_{2} \text { incorporated } \\
\text { Carbon Aerogel C(PI) }\end{array}$ & 330 & 19 & 1.6 \\
\hline
\end{tabular}

The composite material was tested for $\mathrm{H}_{2}$ desorption in the temperature range of RT to $350{ }^{\circ} \mathrm{C}$. Figure 42 shows $\mathrm{H}_{2}$ desorption curves of $\mathrm{Ca}\left(\mathrm{BH}_{4}\right)_{2}$ incorporated in the $\mathrm{C}(\mathrm{PI})$ aerogel, compared with SPEX milled $\mathrm{Ca}\left(\mathrm{BH}_{4}\right)_{2}$ and $\mathrm{Ca}\left(\mathrm{BH}_{4}\right)_{2}-\mathrm{C}(\mathrm{PI})$ mixture. The data indicated that the incorporated $\mathrm{Ca}\left(\mathrm{BH}_{4}\right)_{2}$ started to release $\mathrm{H}_{2}$ at $c a$. $150-175{ }^{\circ} \mathrm{C}$, much lower than the SPEX milled material. However, the $\mathrm{H}_{2}$ desorption capacity was lower than the SPEX milled material. We believe this was due to an error in estimating hydride loading level. Accurate loading measurement was a focus in subsequent synthesis round to better quantify desorption capacity. 


\section{Hydride - Framework Composite Testing}

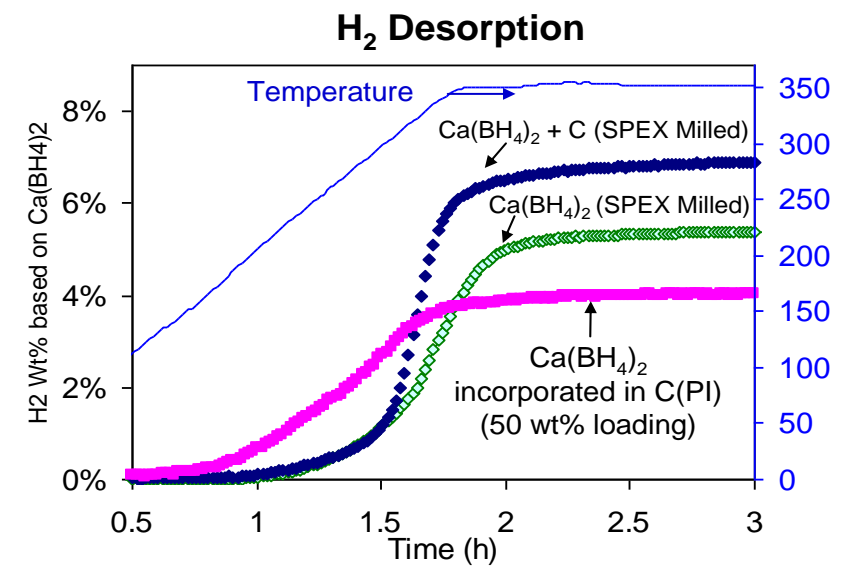

Figure 42: $\mathrm{H}_{2}$ desorption of $\mathrm{Ca}\left(\mathrm{BH}_{4}\right)_{2}$ incorporated in $\mathrm{C}(\mathrm{PI})$ aerogel.

In order to verify the $\mathrm{H}_{2}$ desorption capacity of incorporated $\mathrm{Ca}\left(\mathrm{BH}_{4}\right)_{2}$, a second sample of $\mathrm{Ca}\left(\mathrm{BH}_{4}\right)_{2}$ incorporated in $\mathrm{C}(\mathrm{PI})$ aerogel was prepared by the same method. In this sample, additional weight measurements were made to accurately assess the amount of $\mathrm{Ca}\left(\mathrm{BH}_{4}\right)_{2}$ incorporated. It was determined that $42 \%$ of $\mathrm{Ca}\left(\mathrm{BH}_{4}\right)_{2} * 2 \mathrm{THF}$ was infiltrated. The sample was then desolvated at $160{ }^{\circ} \mathrm{C}$ for 24 hours under 60 bar $\mathrm{H}_{2}$ to prevent $\mathrm{H}_{2}$ desorption. $\mathrm{Ca}\left(\mathrm{BH}_{4}\right)_{2}$ loading was measured at 27 wt\%, which is much lower than previous estimation of $50 \mathrm{wt} \%$.

$\mathrm{H}_{2}$ desorption analysis of this second sample was conducted at $350{ }^{\circ} \mathrm{C}$ and $0-1$ bar $\mathrm{H}_{2}$ pressure. The desorption curve shown in Figure 43 confirmed that the onset $\mathrm{H}_{2}$ release temperature of the incorporated sample (A) was lower than mechanical (SPEX) mixture (B). In addition, a total of approximate $8 \mathrm{wt} \%$ of $\mathrm{H}_{2}$ was released in the incorporated sample (A), while only less than $7 \mathrm{wt} \%$ of $\mathrm{H}_{2}$ was released in the SPEX milled mixture (B), indicating significant improvement in desorption capacity and kinetics. After the $1^{\text {st }}$ desorption, the samples were rehydrogenated at $350{ }^{\circ} \mathrm{C}, 190$ bar $\mathrm{H}_{2}$ for 24 hours. Figure 44 shows the results of the $2^{\text {nd }} \mathrm{H}_{2}$ desorption conducted under the same condition as the first desorption. Three hydrogen releasing periods were observed. For the incorporated $\mathrm{Ca}\left(\mathrm{BH}_{4}\right)_{2}$, the first period is from 50 to $280{ }^{\circ} \mathrm{C}$, releasing approximately $0.8 \mathrm{wt} \% \mathrm{H}_{2}$. The second is from 280 to $350{ }^{\circ} \mathrm{C}$, releasing approximately $1.7 \mathrm{wt} \% \mathrm{H}_{2}$. The third one is at $350{ }^{\circ} \mathrm{C}$, releasing an additional $1.3 \mathrm{wt} \%$ in this isothermal period. A total $3.8 \mathrm{wt} \% \mathrm{H}_{2}$ was released, similar to that of the SPEX milled material. The results indicated that incorporation of $\mathrm{Ca}\left(\mathrm{BH}_{4}\right)_{2}$ in $\mathrm{C}(\mathrm{PI})$ aerogel did not result in significant improvement in rehydrogenation under these rehydriding conditions. However, the incorporated sample started to release $\mathrm{H}_{2}$ at a very low temperature, much lower than the first cycle. It was not clear why this happened. Additional samples were prepared for solid state NMR to analyze products of $\mathrm{Ca}\left(\mathrm{BH}_{4}\right)_{2}$ rehydrogenation inside aerogel. 


\section{Hydride - Framework Composite Testing}

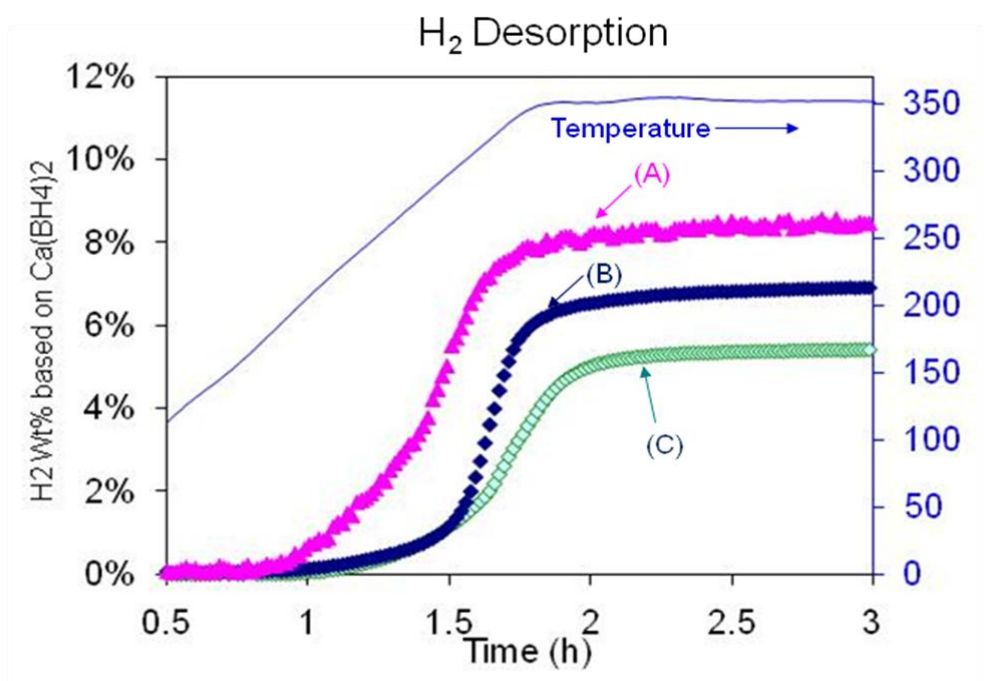

Figure 43: Hydrogen desorption of $\mathrm{Ca}\left(\mathrm{BH}_{4}\right)_{2}$ incorporated in $\mathrm{C}(\mathrm{PI})$ aerogels.

(A) $\mathrm{Ca}\left(\mathrm{BH}_{4}\right)_{2}$ SPEX milled with $\mathrm{C}(\mathrm{PI})$ aerogels.

(B) SPEX milled $\mathrm{Ca}\left(\mathrm{BH}_{4}\right)_{2}$.

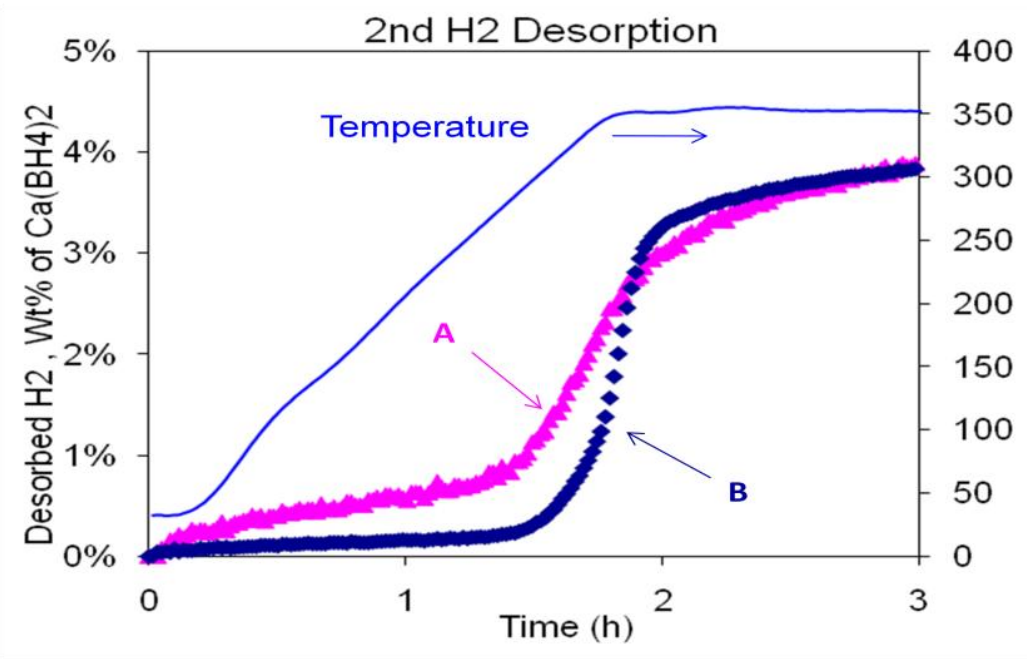

Figure 44: $2^{\text {nd }} \mathrm{H}_{2}$ desorption of:

(A) $\mathrm{Ca}\left(\mathrm{BH}_{4}\right)_{2}$ incorporated in $\mathrm{C}(\mathrm{PI})$ aerogel.

(B) $\mathrm{Ca}\left(\mathrm{BH}_{4}\right)_{2}$ SPEX milled with $\mathrm{C}(\mathrm{PI})$ aerogel. 


\section{Hydride - Framework Composite Testing}

$\mathrm{Ca}\left(\mathrm{BH}_{4}\right)_{2}-\mathrm{C}(\mathrm{PI})$ aerogel composite was further examined by SEM to understand the incorporation process and composite morphology. Figure 45 shows back scattered SEM image of the cross section of monolithic $\mathrm{C}(\mathrm{PI})$ aerogel incorporated with $\mathrm{Ca}\left(\mathrm{BH}_{4}\right)_{2}$. The light color portion is $\mathrm{Ca}\left(\mathrm{BH}_{4}\right)_{2}$ rich and the dark area is $\mathrm{C}$ rich area. It can be clearly seen that $\mathrm{Ca}\left(\mathrm{BH}_{4}\right)_{2}$ was infiltrated into the interior of the monolithic $\mathrm{C}$ aerogel. However, $\mathrm{Ca}\left(\mathrm{BH}_{4}\right)_{2}$ was not uniformly distributed within the aerogel.

The BET surface area measurements of the as-received $\mathrm{C}(\mathrm{PI})$ aerogel and the $\mathrm{Ca}\left(\mathrm{BH}_{4}\right)_{2}$ incorporated one shows that average pore size was reduced from 25 to $19 \mathrm{~nm}$ and the pore volume from 3.7 to 1.6 $\mathrm{cc} / \mathrm{g}$. It can be estimated that $57 \%$ of the pore volume was filled with $\mathrm{Ca}\left(\mathrm{BH}_{4}\right)_{2}$. Pore size distributions of the aerogels before and after incorporation are shown in Figure 46. Based on the distribution curves, it appears that $\mathrm{Ca}\left(\mathrm{BH}_{4}\right)_{2}$ solution preferentially penetrated into large pores / channels in the framework, indicating remaining unfilled pores consisted of mostly small pores $(<19$ $\mathrm{nm})$, which was consistent with the SEM image.

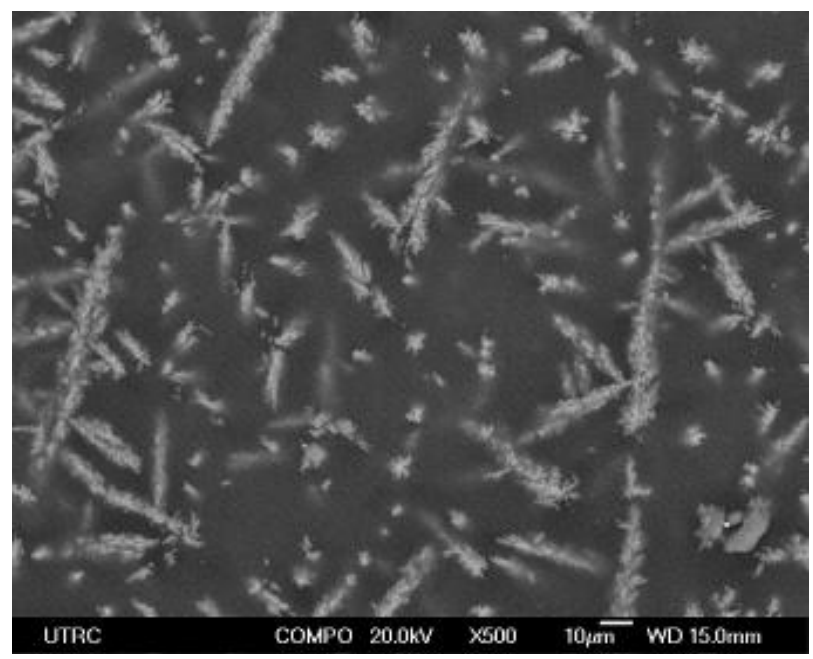

Figure 45: Cross - section morphology of $\mathrm{Ca}\left(\mathrm{BH}_{4}\right)_{2}$ incorporated in $\mathrm{C}(\mathrm{PI})$ aerogel.

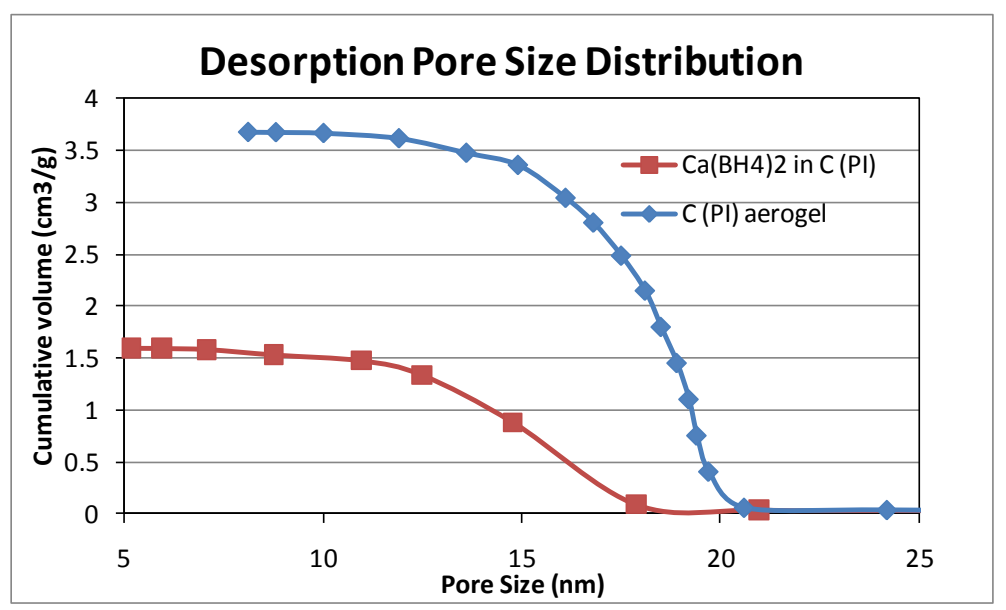

Figure 46: Pore size distribution on desorption cycle in $\mathrm{N}_{2}$ BET measurement. 


\section{Hydride - Framework Composite Testing}

\subsection{Evaluation of $\mathrm{Ca}\left(\mathrm{BH}_{4}\right)_{2}$ Incorporated in $\mathrm{C}(\mathrm{PF})$ Aerogels}

Based on the reactivity study of nano-framework and $\mathrm{Ca}\left(\mathrm{BH}_{4}\right)_{2}$, the $\mathrm{C}(\mathrm{PF})$ did not form nitride products. It also had better $\mathrm{H}_{2}$ desorption kinetics than $\mathrm{C}(\mathrm{PI})$ aerogel during the second desorption (see section 5.3 and 5.4). A sample of $\mathrm{Ca}\left(\mathrm{BH}_{4}\right)_{2}$ incorporated in $\mathrm{C}(\mathrm{PF})$ aerogel was tested for $\mathrm{H}_{2}$ desorption and absorption property.

The $\mathrm{H}_{2}$ desorption analysis was conducted at room temperature to $350^{\circ} \mathrm{C}$ and $\mathrm{H}_{2}$ pressure of $0-1$ bar. The desorption curve A shown in Figure 47 confirmed the lower onset $\mathrm{H}_{2}$ release temperature than that of SPEX milled mixture, similar to the observation in $\mathrm{Ca}\left(\mathrm{BH}_{4}\right)_{2}-\mathrm{C}(\mathrm{PI})$ composite. $\mathrm{H}_{2}$ desorption kinetics was also improved over the SPEX milled mixture. Approximately $7 \mathrm{wt} \%$ of $\mathrm{H}_{2}$ (based on $\mathrm{Ca}\left(\mathrm{BH}_{4}\right)_{2}$ incorporated) was released in this sample during $1^{\text {st }}$ desorption, which was lower than the 8 wt\% of $\mathrm{H}_{2}$ released in the $\mathrm{Ca}\left(\mathrm{BH}_{4}\right)_{2}-\mathrm{C}(\mathrm{PI})$ aerogel composite incorporated from solution. Its $\mathrm{H}_{2}$ desorption kinetics was also slower than the SNL sample. These may be due to the higher hydride loading in UTRC sample (38.96 wt\%) than that of the SNL sample (27 wt \%). This increased loading could lead to reduction in the surface contact area between hydride and the aerogel pore wall, resulting in reduced catalyzation effect. During the second desorption after recharging at $350{ }^{\circ} \mathrm{C} / 190$ bar $\mathrm{H}_{2}$, a total of $3.6 \mathrm{wt} \% \mathrm{H}_{2}$ was released. This is similar to the amount released from $\mathrm{Ca}\left(\mathrm{BH}_{4}\right)_{2}-$ $\mathrm{C}(\mathrm{PI})$ aerogel composite during $2^{\text {nd }}$ desorption.

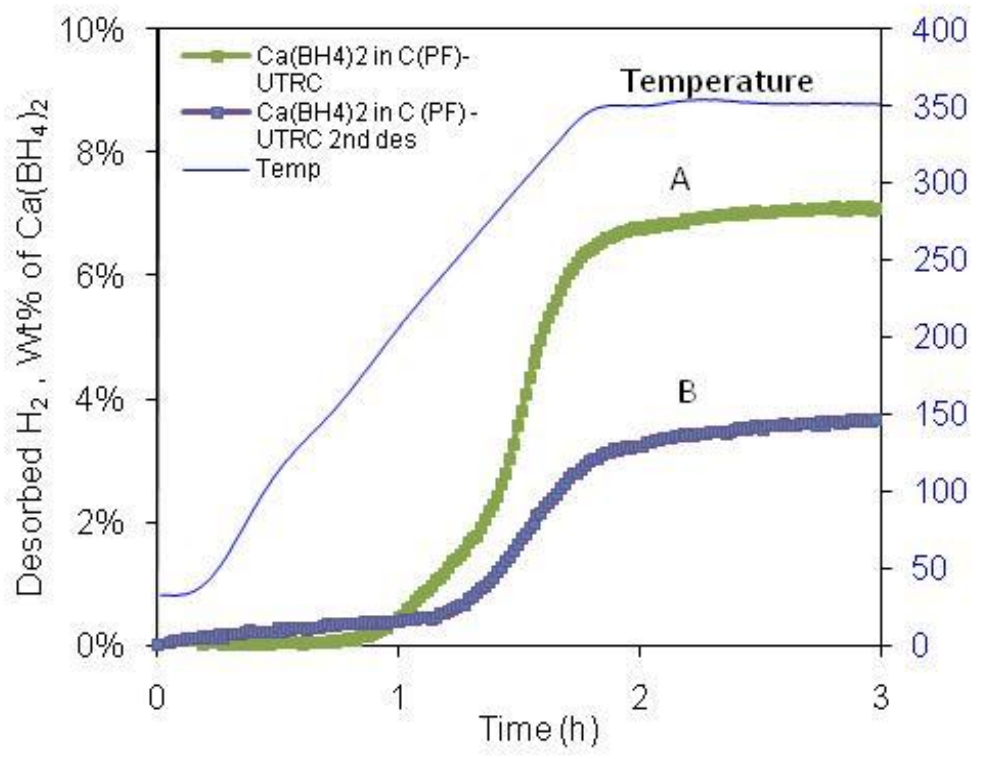

Figure 47: Hydrogen desorption of $\mathrm{Ca}\left(\mathrm{BH}_{4}\right)_{2}$ incorporated in $\mathrm{C}(\mathrm{PF})$ aerogel:

(A) $1^{\text {st }}$ desorption.

(B) $2^{\text {nd }}$ desorption after recharging at $350{ }^{\circ} \mathrm{C} / 190$ bar $\mathrm{H}_{2}$ pressure.

In order to understand rehydrogenation of borohydride incorporated in $\mathrm{C}$ aerogel, a series of $\mathrm{Ca}\left(\mathrm{BH}_{4}\right)_{2}-\mathrm{C}(\mathrm{PF})$ aerogel composite samples were prepared at UTRC for solid state NMR characterization. The Solid State NMR was conducted by Sonjong Hwang at California Institute of Technology. 


\section{Hydride - Framework Composite Testing}

Figure 48 shows the ${ }^{11} \mathrm{~B}$ MAS NMR spectra of $\mathrm{Ca}\left(\mathrm{BH}_{4}\right)_{2}-\mathrm{C}(\mathrm{PF})$ composite at various stage of cycles. The as incorporated material shows a sharp $\mathrm{Ca}\left(\mathrm{BH}_{4}\right)_{2}$ at $c a$. $-35 \mathrm{ppm}$ (Figure 48a). This peak disappears after desorption at $350^{\circ} \mathrm{C}$ for 24 hours (Figure 48b). It forms abroad peak from $c a$. - 40 to $30 \mathrm{ppm}$, indicating formation of boride. The small peak at $c a .10 \mathrm{ppm}$ is attributed to oxygen contamination. The $\mathrm{O}$ contamination could possibly come from two sources. One is the decomposition of the small amount of THF ligand from incomplete desolvation. The other is the oxygen containing functional group on the surface of $\mathrm{C}(\mathrm{PF})$. Formation of $\mathrm{Ca}\left(\mathrm{BH}_{4}\right)_{2}$ upon recharging at $350{ }^{\circ} \mathrm{C}$ and 190 bar pressure was observed (Figure $48 \mathrm{c}$ ). However, this $\mathrm{Ca}\left(\mathrm{BH}_{4}\right)_{2}$ peak is broad comparing to the as-made material, and the peak position is slightly shifted. $\mathrm{CaB}_{12} \mathrm{H}_{12}$ was observed in the recharged sample. This compound appears to accumulate upon additional cycling (Figure 48d). $\mathrm{CaB}_{12} \mathrm{H}_{12}$ is a stable compound. It can hinder the formation of $\mathrm{Ca}\left(\mathrm{BH}_{4}\right)_{2}$ during rehydriding. Its formation was considered the main reason behind the reduction of reversible capacity in borohydrides. Figure 49 shows the reabsorbed $\mathrm{Ca}\left(\mathrm{BH}_{4}\right)_{2}$ incorporated in $\mathrm{C}(\mathrm{PF})$, in comparison with bulk $\mathrm{Ca}\left(\mathrm{BH}_{4}\right)_{2}$ SPEX milled with $\mathrm{C}$. Formation of $\mathrm{Ca}\left(\mathrm{BH}_{4}\right)_{2}$ and $\mathrm{CaB}_{12} \mathrm{H}_{12}$ was observed in both samples. The signal of $\mathrm{Ca}\left(\mathrm{BH}_{4}\right)_{2}$ formed inside $\mathrm{C}$ aerogel is broad and slightly shifted peak, compared to the peak from SPEX milled sample. This indicates that $\mathrm{Ca}\left(\mathrm{BH}_{4}\right)_{2}$ formed inside $\mathrm{C}$ aerogel may have different structure than that formed in bulk.

Figure 1 ${ }^{11}$ B MAS NMR $\quad \omega_{\mathrm{r}}=15 \mathrm{kHz}$

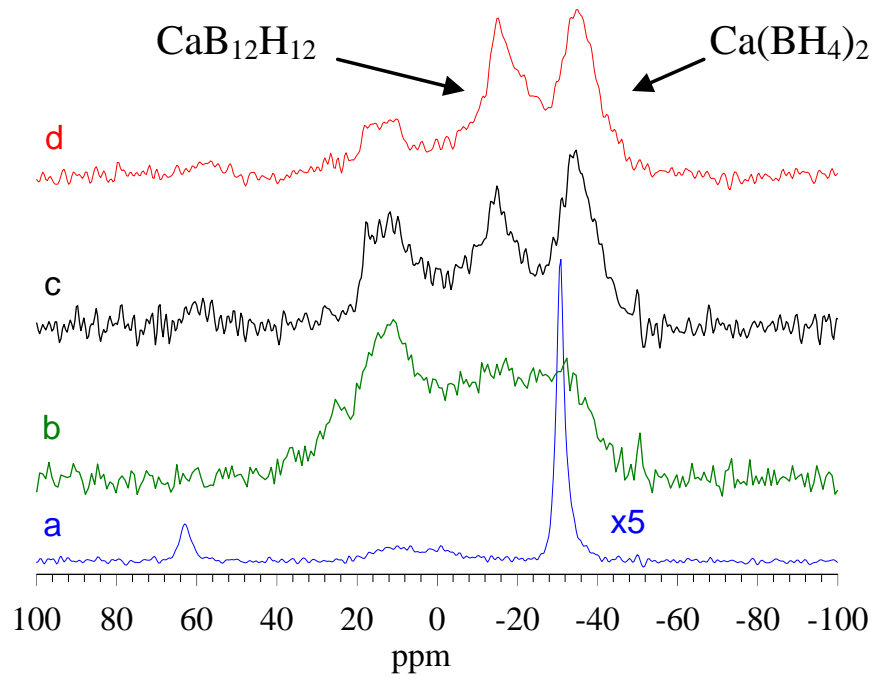

Figure 48: Solid State NMR of a) $\mathrm{Ca}\left(\mathrm{BH}_{4}\right)_{2}$ incorporated in C-aerogel;

a) As made: $38 \mathrm{wt} \%$ of $\mathrm{Ca}\left(\mathrm{BH}_{4}\right)_{2}$,

b) $\mathrm{Ca}\left(\mathrm{BH}_{4}\right)_{2}$ incorporated in $\mathrm{C}$-aerogel; discharged at $350{ }^{\circ} \mathrm{C}$ for $24 \mathrm{hour} / 1 \mathrm{bar}$ $\mathrm{H}_{2}$,

c) $\mathrm{Ca}\left(\mathrm{BH}_{4}\right)_{2}$ incorporated in $\mathrm{C}$-aerogel; cycled at $350{ }^{\circ} \mathrm{C}$, and

d) $\mathrm{Ca}\left(\mathrm{BH}_{4}\right)_{2}$ incorporated in $\mathrm{C}$-aerogel; after three cycled of hydrogenation. 


\section{Hydride - Framework Composite Testing}

UTRC09_11B_Fig 2
${ }^{11}$ B MAS NMR
$\omega_{\mathrm{r}}=15 \mathrm{kHz}$

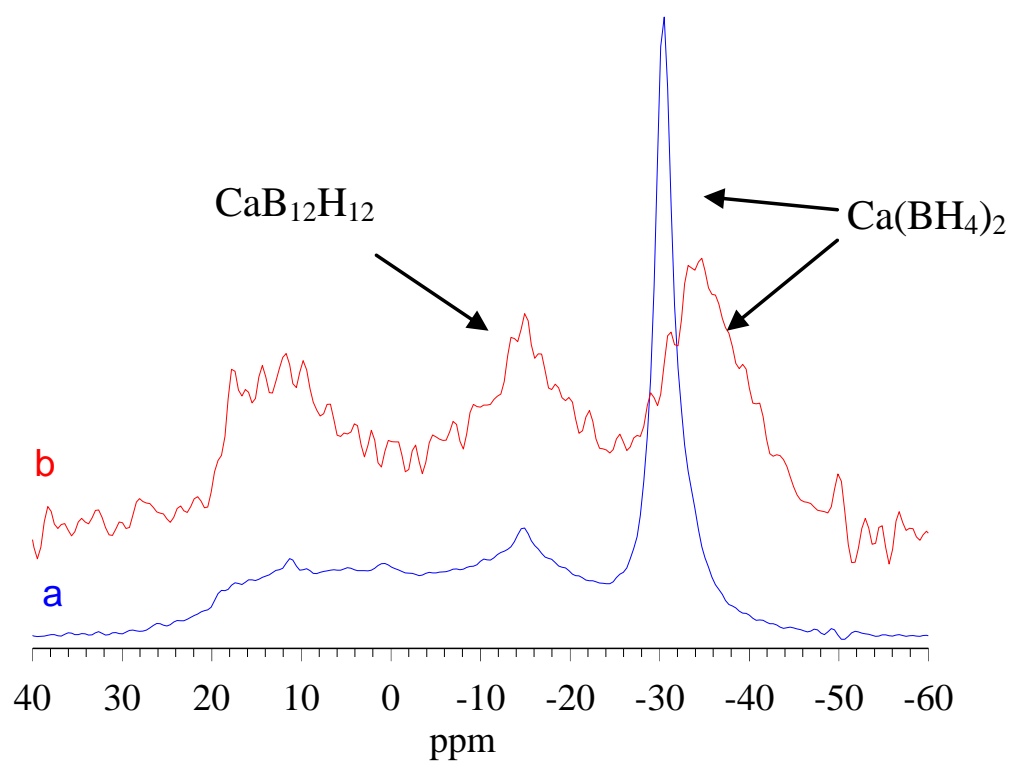

Figure 49: Solid State NMR of

a) Bulk $\mathrm{Ca}\left(\mathrm{BH}_{4}\right)_{2}$ (SPEX milled), discharged and recharged.

b) $\mathrm{Ca}\left(\mathrm{BH}_{4}\right)_{2}$ in $\mathrm{C}(\mathrm{PF})$ aerogel; discharged and recharged.

These testing results indicated that incorporation of $\mathrm{Ca}\left(\mathrm{BH}_{4}\right)_{2}$ in $\mathrm{C}$ aerogels (both $\mathrm{PI}$ and $\mathrm{PF}$ derived) improved dehydrogenation kinetics significantly, but it could not increase rehydrogenation under these hydriding conditions due to their inability of circumvent the formation of the stable intermediate, $\mathrm{CaB}_{12} \mathrm{H}_{12}$.

\subsection{Evaluation $\mathrm{Ca}\left(\mathrm{BH}_{4}\right)_{2}$ Incorporated in Pt-Catalyzed $\mathrm{ZrO}_{2}$ Aerogel}

$\mathrm{H}_{2}$ desorption and absorption performance of $\mathrm{Ca}\left(\mathrm{BH}_{4}\right)_{2}$ incorporated in Pt-catalyzed yttria-stabilized zirconia (Pt/YSZ) was tested in Sievert's apparatus. Figure 50 shows the $1^{\text {st }}$ cycle $\mathrm{H}_{2}$ desorption of $\mathrm{Ca}\left(\mathrm{BH}_{4}\right)_{2}-\mathrm{Pt} / \mathrm{YSZ}$ composite, in comparison with SPEX milled $\mathrm{Ca}\left(\mathrm{BH}_{4}\right)_{2}$ and its SPEX milled mixture with Pt/YSZ. The $\mathrm{H}_{2}$ desorption capacity of the former, calculated based on the weight of $\mathrm{Ca}\left(\mathrm{BH}_{4}\right)_{2}$, is higher than the SPEX milled $\mathrm{Ca}\left(\mathrm{BH}_{4}\right)_{2}$, but lower than the SPEX milled mixture of $\mathrm{Ca}\left(\mathrm{BH}_{4}\right)_{2}$ and $\mathrm{Pt} / \mathrm{YSZ}$. The higher $\mathrm{H}_{2}$ capacity from SPEX-milled mixture of $\mathrm{Ca}\left(\mathrm{BH}_{4}\right)_{2}$ and $\mathrm{Pt} / \mathrm{YSZ}$ is probably due to reaction of $\mathrm{Ca}\left(\mathrm{BH}_{4}\right)_{2}$ with residual hydroxyl group on $\mathrm{Pt} / \mathrm{YSZ}$ surface. In the incorporated sample, this reaction occurs during the solvent-assisted incorporation. Therefore, the $\mathrm{H}_{2}$ capacity was lower than the SPEX milled mixture in the first desorption cycle. The $\mathrm{H}_{2}$ releasing kinetics of the incorporated material was faster than the two SPEX milled materials. It showed that the incorporation of $\mathrm{Ca}\left(\mathrm{BH}_{4}\right)_{2}$ in the $\mathrm{Pt} / \mathrm{YSZ}$ aerogel could enhance $\mathrm{H}_{2}$ desorption kinetics, similar to the effect observed in the $\mathrm{Ca}\left(\mathrm{BH}_{4}\right)_{2}-\mathrm{C}$ composite.

Figure 51 shows the second cycle desorption curve after absorption at $350{ }^{\circ} \mathrm{C}, 190$ bar $\mathrm{H}_{2}$ pressure. The incorporated material released $2.61 \%$ of $\mathrm{H}_{2}$ in the second desorption, lower than the $3.26 \%$ 


\section{Hydride - Framework Composite Testing}

release from the two SPEX milled materials. This indicates that it absorbed the lowest amount of $\mathrm{H}_{2}$ during rehydrogenation. It is unclear why the incorporated $\mathrm{Ca}\left(\mathrm{BH}_{4}\right)_{2}-\mathrm{Pt} / \mathrm{YSZ}$ was more difficult to rehydrogenate. One scenario could be that only a small portion of $\mathrm{Ca}\left(\mathrm{BH}_{4}\right)_{2}$ was incorporated in the pores, close to the Pt catalyst. An excess amount of the hydride was coated on the outside of particles. This portion was away from the Pt catalyst and could not benefit from its catalytic effect. The thickness of this coating could highly affect its $\mathrm{H}_{2}$ desorption / absorption kinetics and capacity. Due to time and funding limitations, we did not pursue the mechanism behind its lowered absorption capacity.

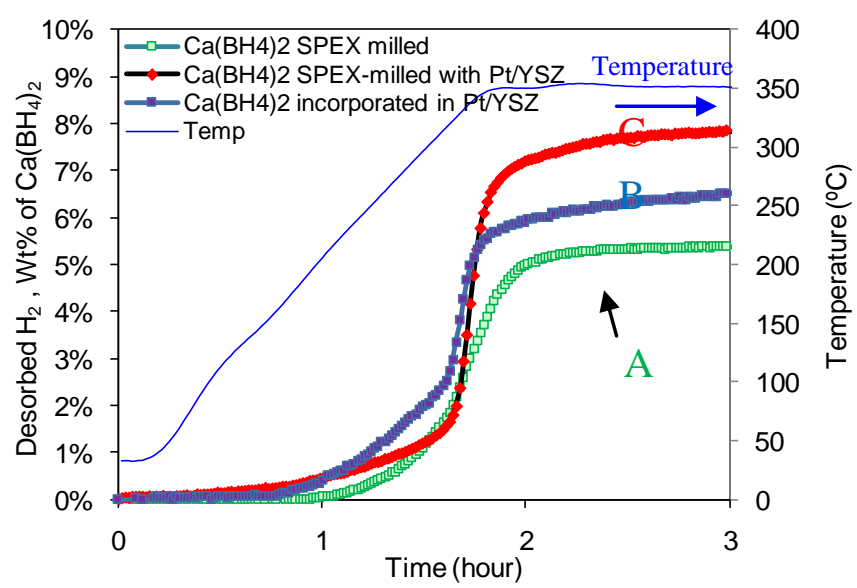

Figure 50: $1^{\text {st }}$ cycle $\mathrm{H}_{2}$ desorption of (A) SPEX milled $\mathrm{Ca}\left(\mathrm{BH}_{4}\right)_{2}$, (B) $\mathrm{Ca}\left(\mathrm{BH}_{4}\right)_{2}$ incorporated in $\mathrm{Pt} / \mathrm{YSZ}$ aerogel and $(\mathrm{C}) \mathrm{Ca}\left(\mathrm{BH}_{4}\right)_{2}$ SPEX milled with Pt/YSZ aerogel.

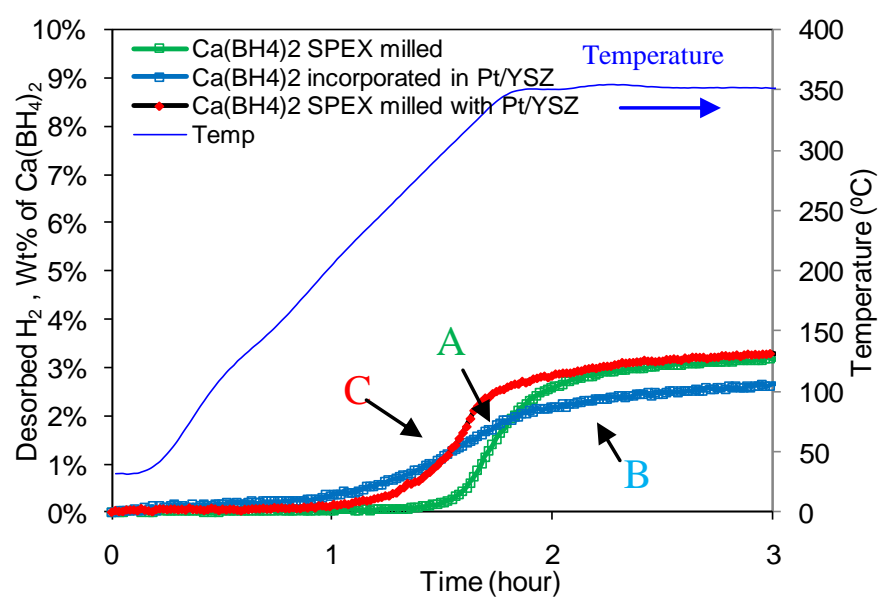

Figure 51: $2^{\text {nd }} \mathrm{H}$ desorption of (A) SPEX milled $\mathrm{Ca}\left(\mathrm{BH}_{4}\right)_{2}$, (B) $\mathrm{Ca}\left(\mathrm{BH}_{4}\right)_{2}$ incorporated in Pt/YSZ aerogel and $(\mathrm{C}) \mathrm{Ca}\left(\mathrm{BH}_{4}\right)_{2}$ SPEX milled with $\mathrm{Pt} / \mathrm{YSZ}$ aerogel after absorption at $350{ }^{\circ} \mathrm{C} 190$ bar $\mathrm{H}_{2}$ pressure. 


\section{Hydride - Framework Composite Testing}

\subsection{Down Selection of Nano-Framework Materials}

Figure 52 shows the $\mathrm{H}_{2}$ desorption curves of $\mathrm{Ca}\left(\mathrm{BH}_{4}\right)_{2}$ incorporated in $\mathrm{C}$ ( $\mathrm{PI}$ and $\mathrm{PF}$ ) and $\mathrm{Pt} / \mathrm{YSZ}$ aerogels. In both the first cycle and the second cycle desorption, $\mathrm{Ca}\left(\mathrm{BH}_{4}\right)_{2}-\mathrm{C}$ aerogel composites had better desorption kinetics and higher desorption capacity than the $\mathrm{Ca}\left(\mathrm{BH}_{4}\right)_{2}-\mathrm{Pt} / \mathrm{YSZ}$ aerogel composite. The higher desorption capacity in the second desorption also indicated that $\mathrm{Ca}\left(\mathrm{BH}_{4}\right)_{2}-\mathrm{C}$ aerogel composites could absorb more $\mathrm{H}_{2}$ during rehydrogenation. In addition, the bulk density of $\mathrm{C}$ is much smaller than $\mathrm{ZrO}_{2}$. This will result in much less weight penalty, since the nano-framework material does not store $\mathrm{H}_{2}$. Therefore, $\mathrm{C}$ aerogels are the most suitable nano-framework for nanoconfinement of calcium borohydride.

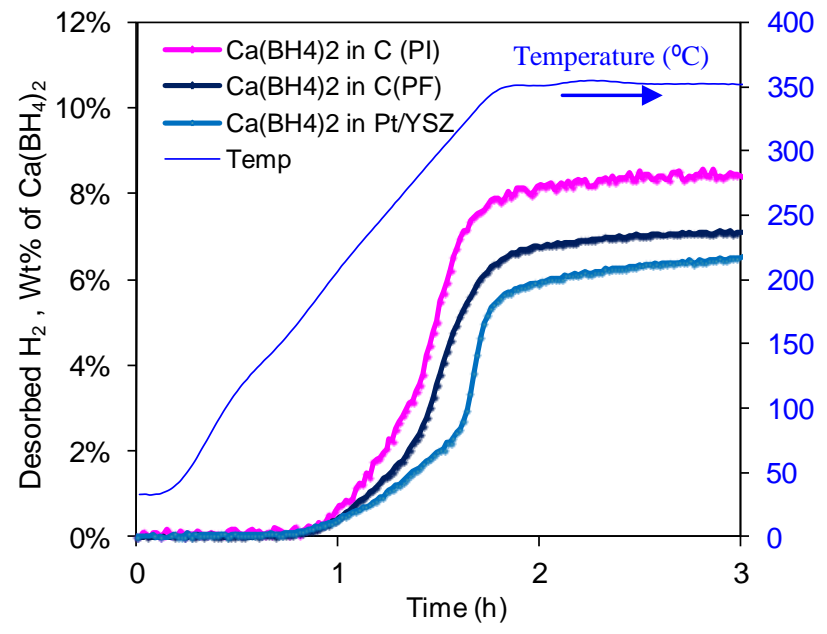

(A)

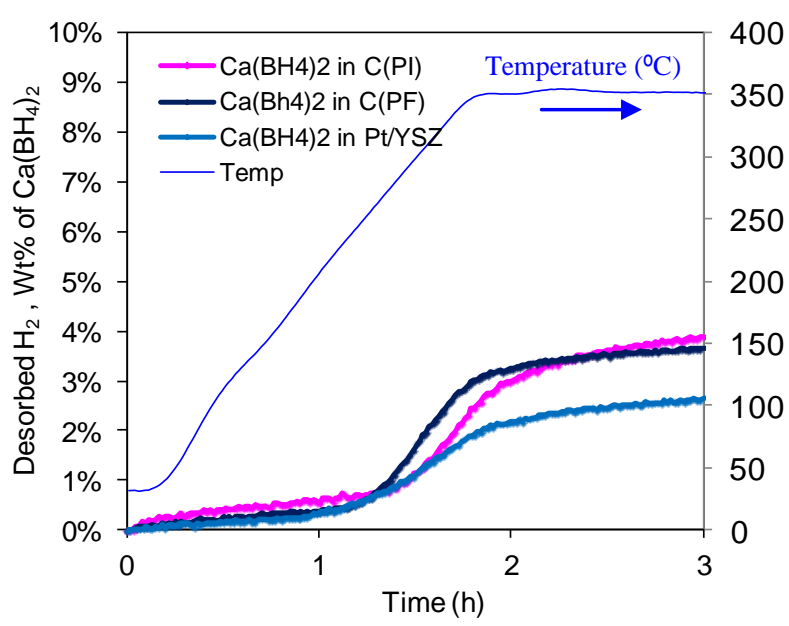

(B)

Figure 52: Comparison of $\mathrm{H}_{2}$ desorption properties of $\mathrm{Ca}\left(\mathrm{BH}_{4}\right)_{2}$ incorporated in $\mathrm{C}$ and $\mathrm{Pt} / \mathrm{YSZ}$ aerogel.

(A) $1^{\text {st }} \mathrm{H}_{2}$ desorption after incorporation and desolvation.

(B) $2^{\text {nd }} \mathrm{H}_{2}$ desorption after absorption at $350^{\circ} \mathrm{C}, 190$ bar $\mathrm{H}_{2}$ pressure.

\subsection{Evaluation of $\mathrm{Mg}\left(\mathrm{BH}_{4}\right)_{2}$ Incorporated in $\mathrm{C}(\mathrm{PF})$ aerogel}

$\mathrm{Mg}\left(\mathrm{BH}_{4}\right)_{2}$ was incorporated in $\mathrm{C}(\mathrm{PF})$ aerogel in the form of etherate (Section 6.2) by incipient wetness method. In order to develop desolvation method, TGA analysis was conducted at various stages to monitor the evolving of $\mathrm{H}_{2}$ and ether. Figure 53 shows the TGA-MS of $\mathrm{Mg}\left(\mathrm{BH}_{4}\right)_{2}$ incorporated in $\mathrm{C}(\mathrm{PF})$ after drying at $80{ }^{\circ} \mathrm{C}$ overnight. In this sample, $\mathrm{H}_{2}$ release starts at slightly below $100{ }^{\circ} \mathrm{C}$, with a minor peak at ca $135^{\circ} \mathrm{C}$ and a major peak at $290{ }^{\circ} \mathrm{C}$. Ether was released in two peaks at $120^{\circ} \mathrm{C}$ and $240^{\circ} \mathrm{C}$, respectively.

Figure 54 shows the TGA-MS of $\mathrm{Mg}\left(\mathrm{BH}_{4}\right)_{2}-\mathrm{C}(\mathrm{PF})$ composite after desolvation at $140{ }^{\circ} \mathrm{C}$ in vacuum for 24 hours. The small $\mathrm{H}_{2}$ peak at ca $135^{\circ} \mathrm{C}$ disappeared and two shoulder peaks at $200{ }^{\circ} \mathrm{C}$ and 375 ${ }^{\circ} \mathrm{C}$ appeared, indicating that some amount of $\mathrm{H}_{2}$ may have been lost at this low temperature. The two ether peaks became one broad peak and reduced in size. Figure 55 shows the TGA-MS of $\mathrm{Mg}\left(\mathrm{BH}_{4}\right)_{2}$ in $\mathrm{C}$ aerogel after desolvation at $140{ }^{\circ} \mathrm{C}$ for 48 hours and $200{ }^{\circ} \mathrm{C}$ for 2 hours. The low temperature $\mathrm{H}_{2}$ peak totally disappeared. The peak at $375^{\circ} \mathrm{C}$ increased in size. These results further indicated that 


\section{Hydride - Framework Composite Testing}

some $\mathrm{H}_{2}$ may have been released during desolvation. It appears that the sample was still not completely desolvated. There was a small amount of remaining solvent released around $260{ }^{\circ} \mathrm{C}$. Figure 56 shows the TGA-MS of bulk $\mathrm{Mg}\left(\mathrm{BH}_{4}\right)_{2}$ and its SPEX milled mixture with the C aerogel. The SPEX milled mixture has similar $\mathrm{H}_{2}$ releasing temperature as the nano-confined composite. These preliminary results indicate that it is very difficult to completely remove the diethyl ether ligan from the magnesium borohydride incorporated in $\mathrm{C}$ aerogel. Very little kinetic enhancement through nano-confinement for $\mathrm{Mg}\left(\mathrm{BH}_{4}\right)_{2}$ was observed. The observation was contrary to the case of $\mathrm{Ca}\left(\mathrm{BH}_{4}\right)_{2}$, where significant enhancement in desorption kinetics was observed in nano-confined material.

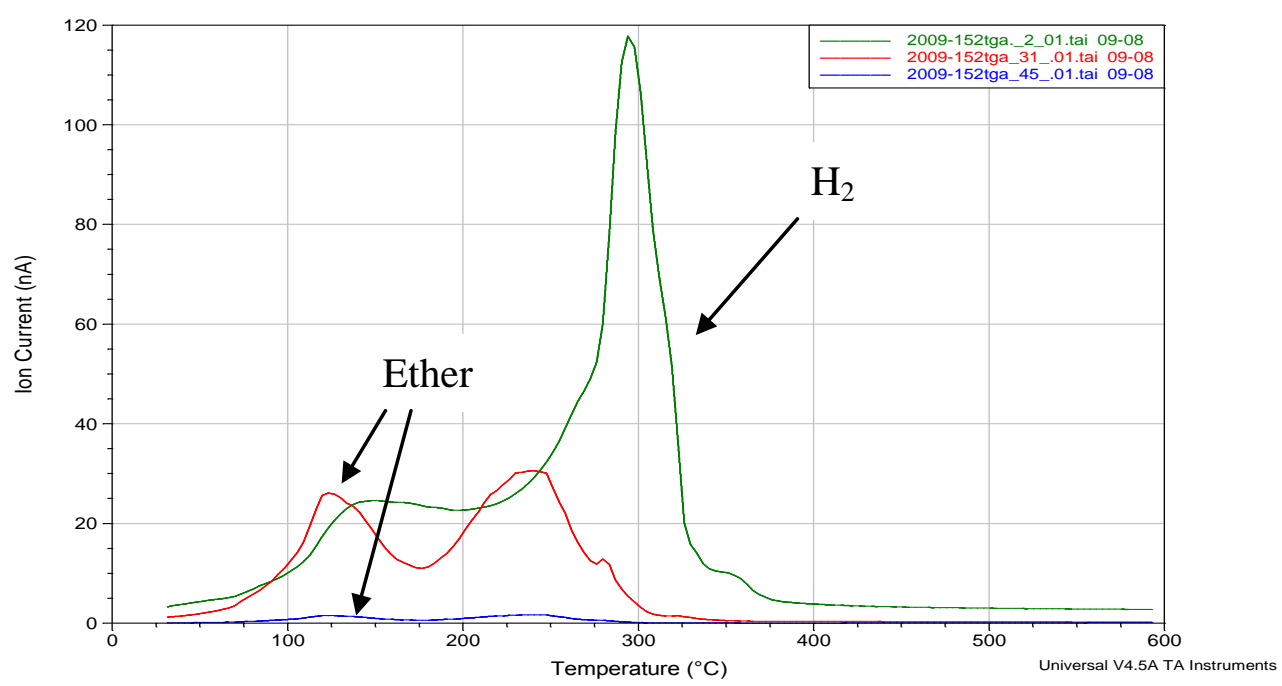

Figure 53: TGA-MS of $\mathrm{Mg}\left(\mathrm{BH}_{4}\right)_{2}$ etherate incorporated in $\mathrm{C}$ aerogel.

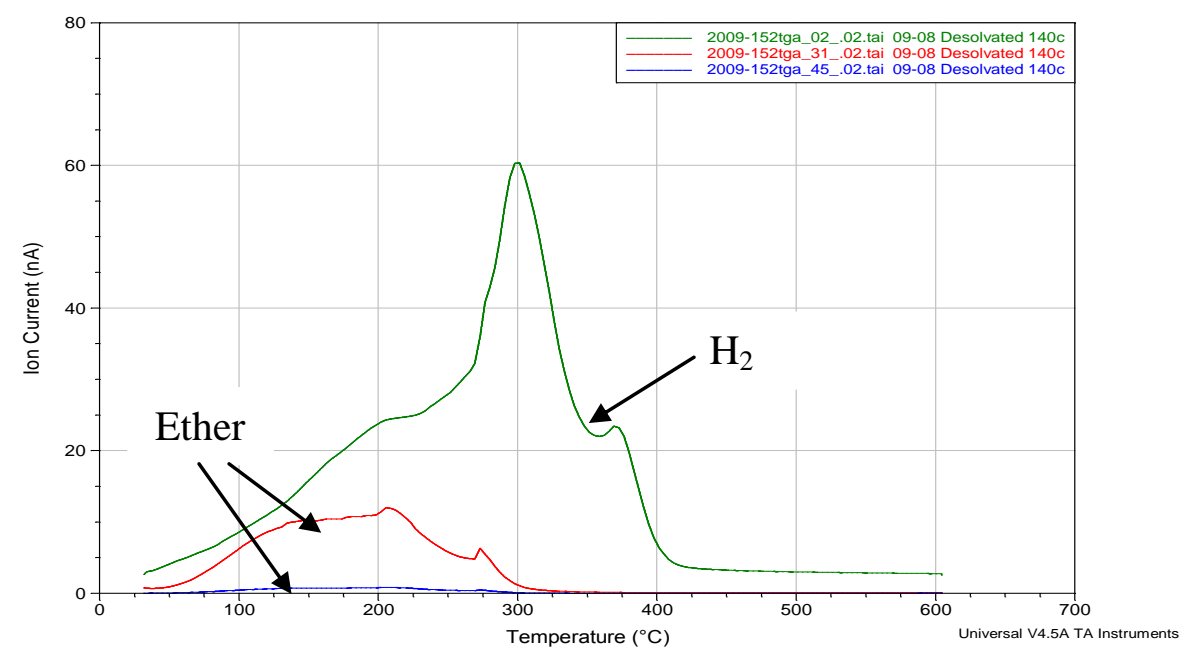

Figure 54: TGA-MS of $\mathrm{Mg}\left(\mathrm{BH}_{4}\right)_{2}$ in $\mathrm{C}$ aerogel after desolvation in vacuum at $140{ }^{\circ} \mathrm{C}$ for 24 hours. 


\section{Hydride - Framework Composite Testing}

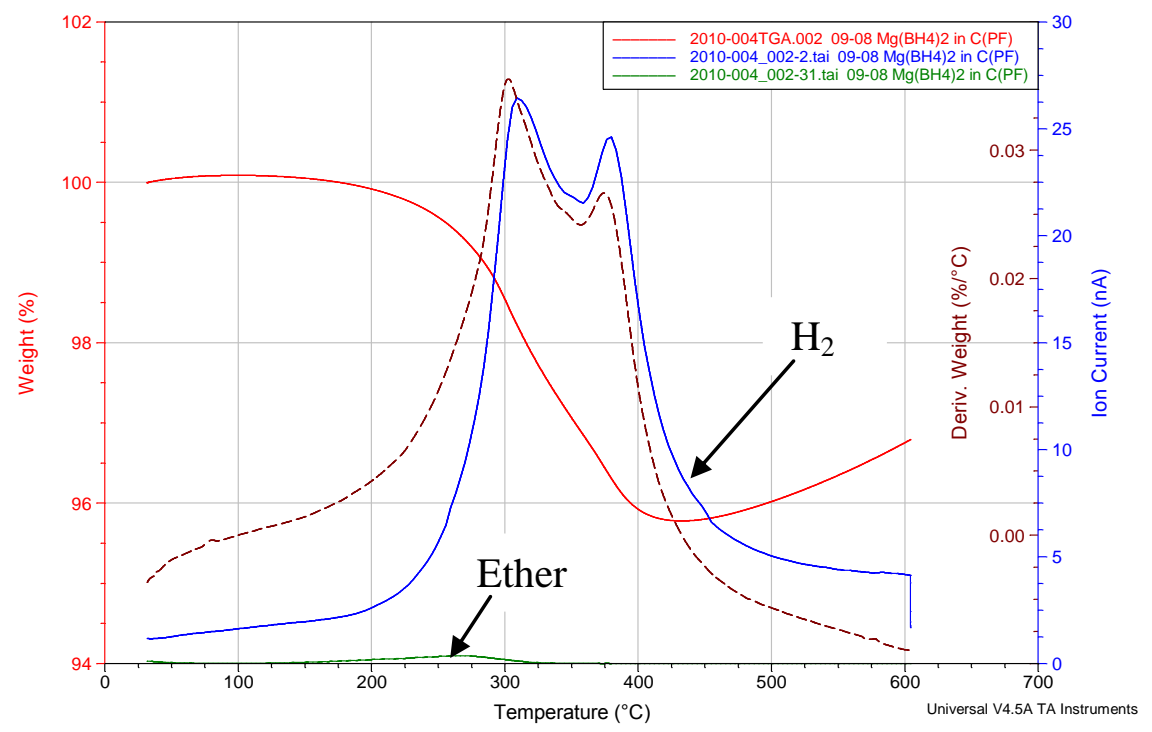

Figure 55: TGA-MS of $\mathrm{Mg}\left(\mathrm{BH}_{4}\right)_{2}$ in $\mathrm{C}$ aerogel after desolvation at $140{ }^{\circ} \mathrm{C}$ for 48 hours and $200{ }^{\circ} \mathrm{C}$ for 2 hours in vacuum.

The $\mathrm{H}_{2}$ desorption behavior of $\mathrm{Mg}\left(\mathrm{BH}_{4}\right)_{2}$ incorporated in the $\mathrm{C}$ aerogel was further evaluated in a Sievert's apparatus. Figure 57(A) shows the $\mathrm{H}_{2}$ desorption curve of $\mathrm{Mg}\left(\mathrm{BH}_{4}\right)_{2}-\mathrm{C}$ aerogel composite that was desolvated at $140{ }^{\circ} \mathrm{C}$ for 48 hours and $200{ }^{\circ} \mathrm{C}$ for 2 hours in vacuum. Only about $1.6 \% \mathrm{H}_{2}$ was desorbed from this sample at $250{ }^{\circ} \mathrm{C}$ based on the weight of $\operatorname{Mg}\left(\mathrm{BH}_{4}\right)_{2}$, while the SPEX milled mixture released $2.6 \mathrm{wt} \% \mathrm{H}_{2}$ under the same conditions. This lowered capacity at $250{ }^{\circ} \mathrm{C}$ also suggests that $\mathrm{H}_{2}$ was lost during desolvation. Desolvation at lower temperature is necessary to prevent from $\mathrm{H}_{2}$ loss during this process. 


\section{Hydride - Framework Composite Testing}

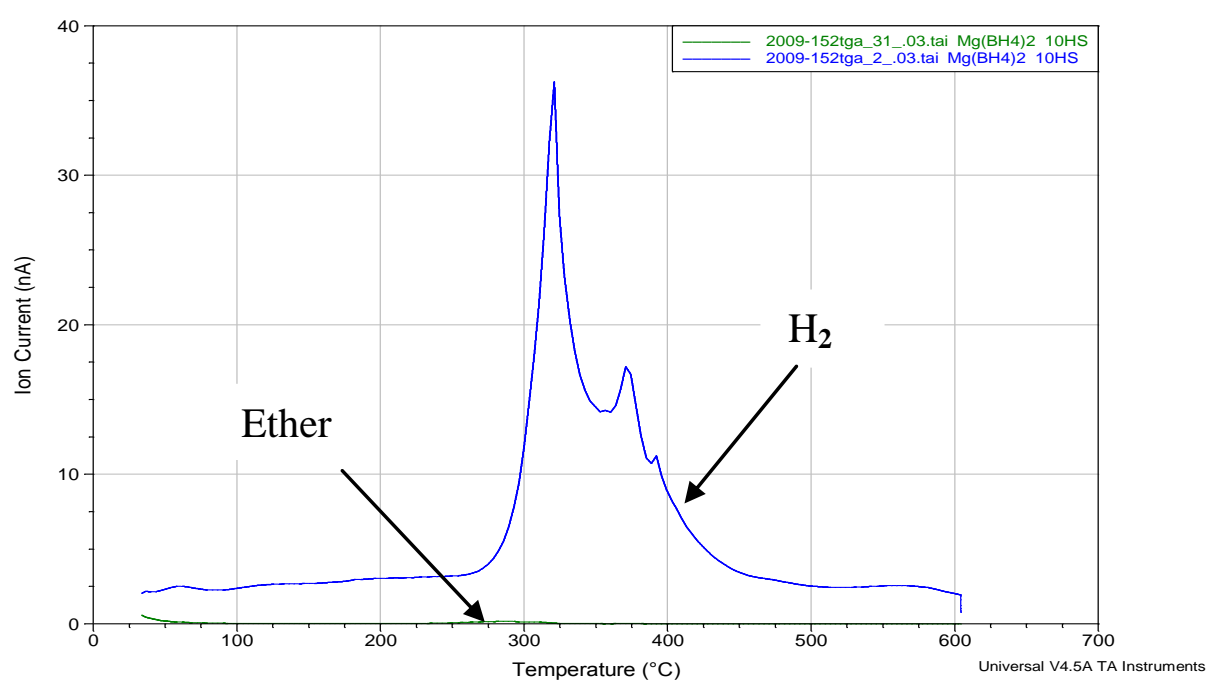

(A)

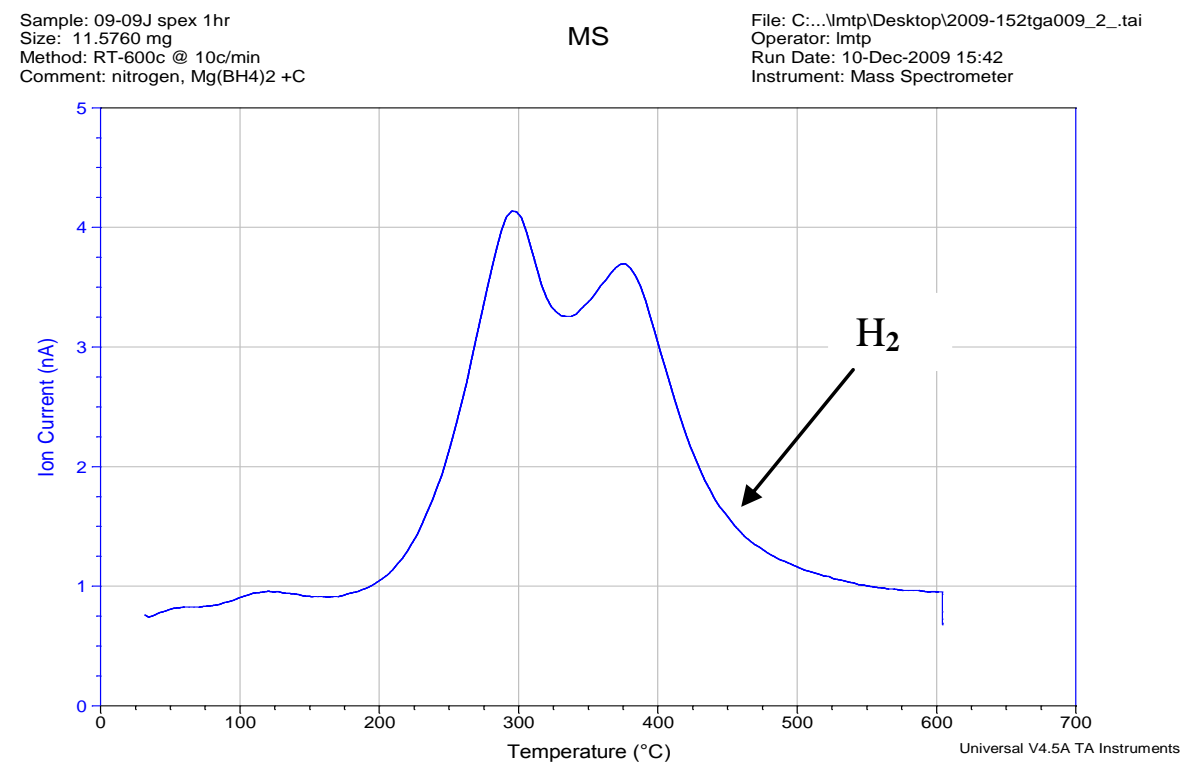

(B)

Figure 56: TGA-MS of (A) as synthesized bulk $\mathrm{Mg}\left(\mathrm{BH}_{4}\right)_{2}$ and (B) SPEX milled mixture of $\mathrm{Mg}\left(\mathrm{BH}_{4}\right)_{2}$ with $\mathrm{C}$ aerogel. 


\section{Hydride - Framework Composite Testing}

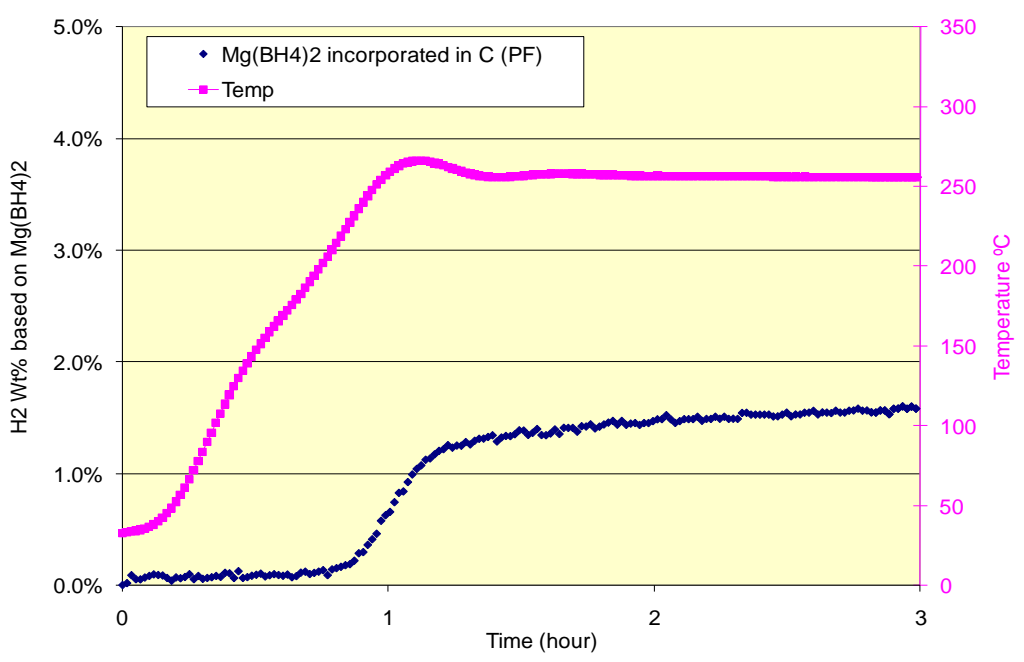

(A)

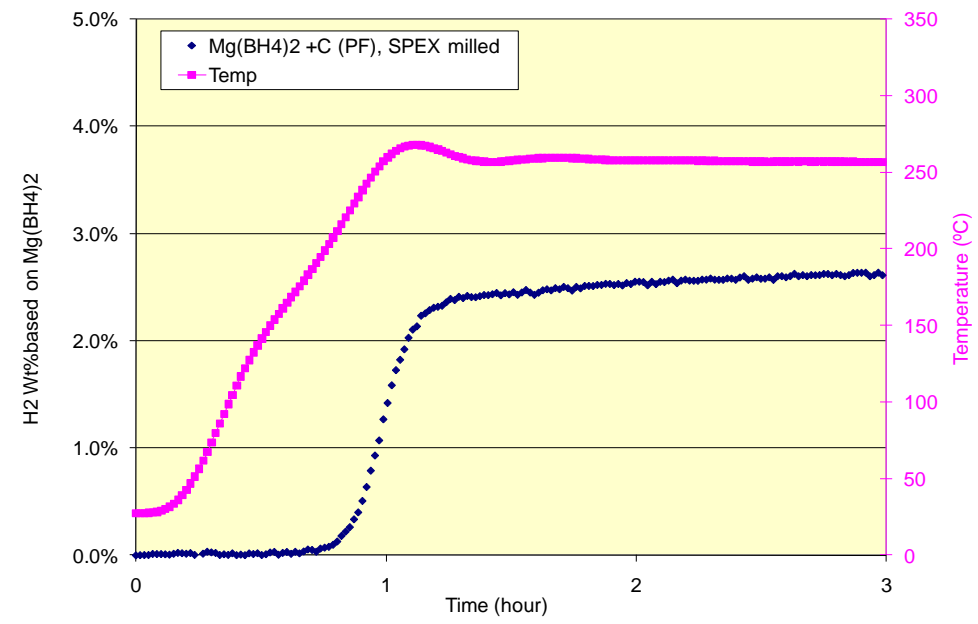

(B)

Figure 57: $\mathrm{H}_{2}$ desorption of (A) $\mathrm{Mg}\left(\mathrm{BH}_{4}\right)_{2}$ incorporated in $\mathrm{C}$ and (B) $\mathrm{Mg}\left(\mathrm{BH}_{4}\right)_{2}$ SPEX milled with C aerogel.

A second batch sample of $\mathrm{Mg}\left(\mathrm{BH}_{4}\right)_{2}$ incorporated in $\mathrm{C}(\mathrm{PF})$ aerogel was prepared at UTRC by incipient wetness method. Approximately $1 \mathrm{~g}$ of $\mathrm{C}$ aerogel was submerged in $\mathrm{Mg}\left(\mathrm{BH}_{4}\right)_{2}$ etherate solution for $30 \mathrm{~min}$. The incorporated material was taken out of the solution and dried at $100{ }^{\circ} \mathrm{C}$ inside a glove box for 1 hour. The sample was resubmerged in $\operatorname{Mg}\left(\mathrm{BH}_{4}\right)_{2}$ etherate solution for a second time to increase hydride loading. The sample was taken out of the solution and dried at $90{ }^{\circ} \mathrm{C}$ overnight in Ar glove box. Desolvation was conducted under vacuum at $140{ }^{\circ} \mathrm{C}$ for 24 hours and then $120{ }^{\circ} \mathrm{C}$ for 


\section{Hydride - Framework Composite Testing}

96 hours. This condition is much milder than the $200^{\circ} \mathrm{C}$ used in the first batch sample. The loading of $\mathrm{Mg}\left(\mathrm{BH}_{4}\right)_{2}$ in the $\mathrm{C}(\mathrm{PF})$ aerogel was $48 \mathrm{wt} \%$.

TGA analysis was again conducted at various stages to monitor the release of $\mathrm{H}_{2}$ and ether. Figure 58 shows the TGA-MS of $\mathrm{Mg}\left(\mathrm{BH}_{4}\right)_{2}$ incorporated in $\mathrm{C}(\mathrm{PF})$ after desolvating at $140{ }^{\circ} \mathrm{C}$ for 24 hours and $120^{\circ} \mathrm{C}$ for 24 hours in dynamic vacuum. In this sample, $\mathrm{H}_{2}$ release starts at $c a .150{ }^{\circ} \mathrm{C}$, with a major peak at $c a .320^{\circ} \mathrm{C}$ and a minor peak at $375^{\circ} \mathrm{C}$. Ether was released in two peaks at $\mathrm{ca} .180{ }^{\circ} \mathrm{C}$ and 235 ${ }^{\circ} \mathrm{C}$, respectively.

The sample was further desolvated for additional 72 hours at $120^{\circ} \mathrm{C}$ in dynamic vacuum. Figure 59 shows the TGA-MS of $\mathrm{Mg}\left(\mathrm{BH}_{4}\right)_{2}-\mathrm{C}(\mathrm{PF})$ composite after desolvation at $140{ }^{\circ} \mathrm{C}$ in vacuum for 24 hours, and $120^{\circ} \mathrm{C}$ for 96 hours. The two ether peaks became one broad peak and reduced in size. It appears that complete desolvation can only occur at temperature of $200{ }^{\circ} \mathrm{C}$ and higher. $\mathrm{H}_{2}$ starts to release at this temperature. Therefore complete desolvation of $\mathrm{Mg}\left(\mathrm{BH}_{4}\right)_{2}$ incorporated in $\mathrm{C}$ aerogel without losing $\mathrm{H}_{2}$ is challenging.

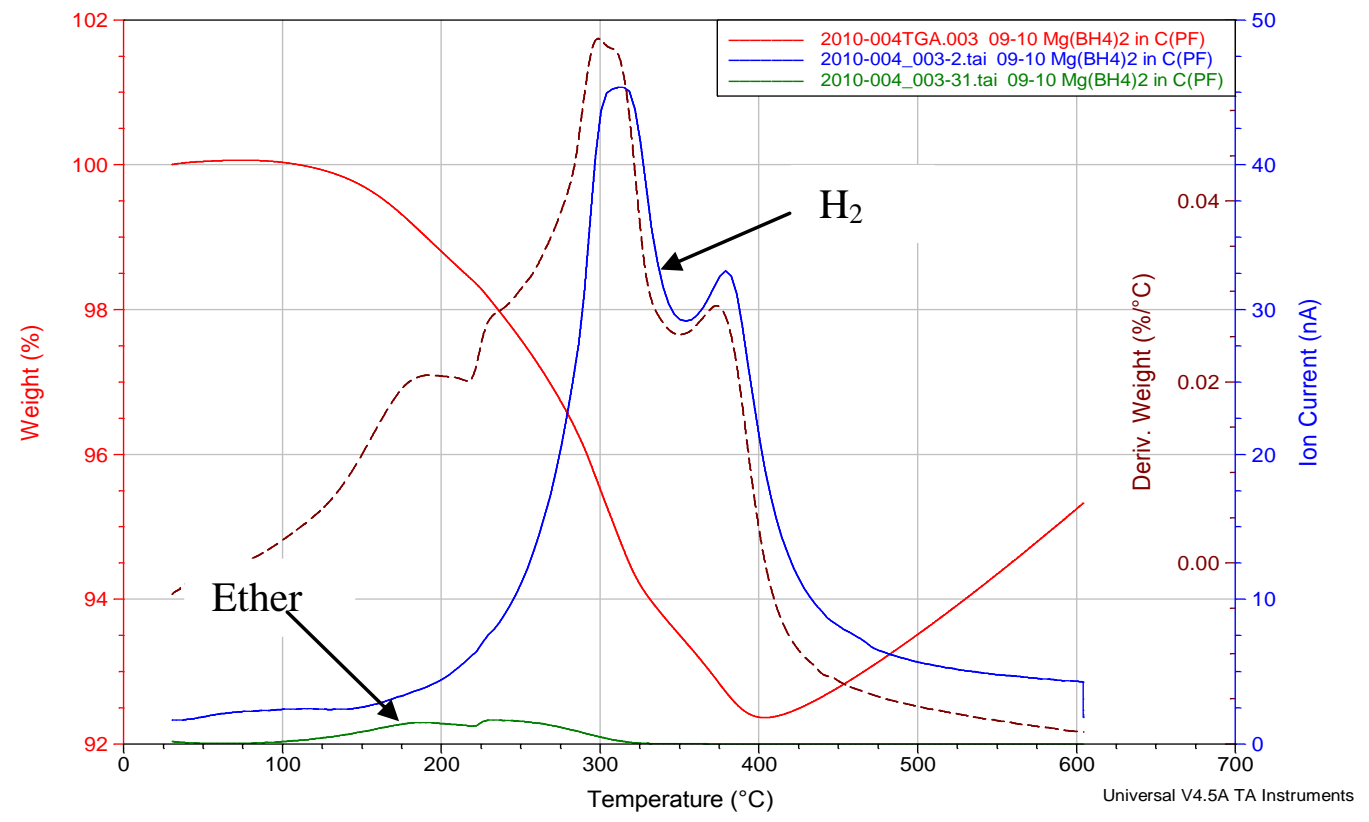

Figure 58: TGA-MS of $\mathrm{Mg}\left(\mathrm{BH}_{4}\right)_{2}$ etherate incorporated in $\mathrm{C}$ aerogel. 


\section{Hydride - Framework Composite Testing}

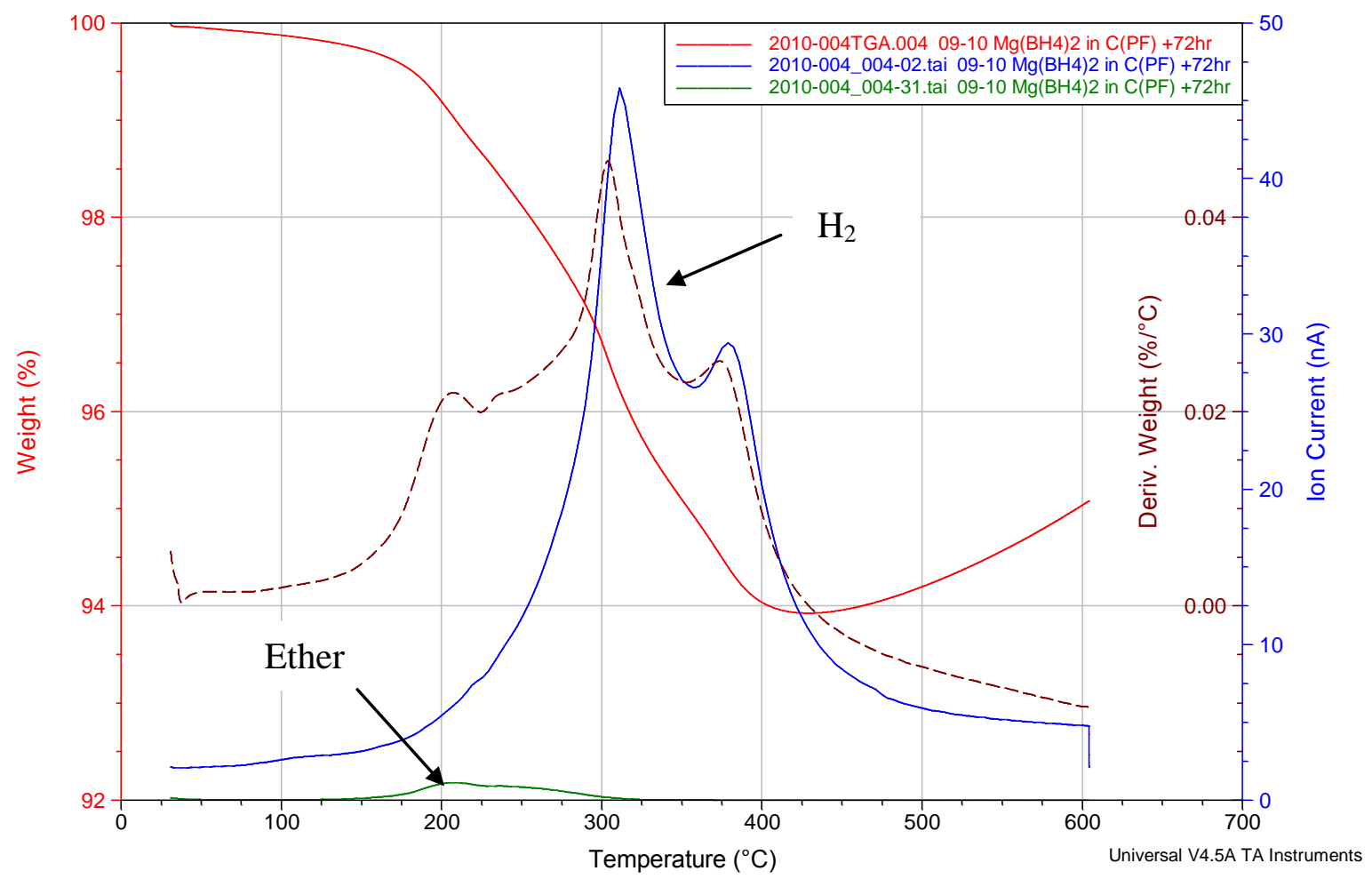

Figure 59: TGA-MS of $\mathrm{Mg}\left(\mathrm{BH}_{4}\right)_{2}$ in $\mathrm{C}$ aerogel after desolvation in vacuum at $140{ }^{\circ} \mathrm{C}$ for 24 hours and $120^{\circ} \mathrm{C}$ for 96 hours.

$\mathrm{H}_{2}$ desorption and absorption behavior of the second batch $\mathrm{Mg}\left(\mathrm{BH}_{4}\right)_{2}$ incorporated in the $\mathrm{C}(\mathrm{PF})$ aerogel was evaluated in a Sievert's apparatus. Figure 60(A) shows the $\mathrm{H}_{2}$ desorption curve of $\mathrm{Mg}\left(\mathrm{BH}_{4}\right)_{2}-\mathrm{C}$ aerogel composition at temperature up to $300{ }^{\circ} \mathrm{C}$, comparing with SPEX milled sample. About $6.7 \mathrm{wt} \% \mathrm{H}_{2}$ was desorbed from this sample at the end of four hours. The SPEX milled bulk material released same amount of $\mathrm{H}_{2}$ under these conditions. The two materials have almost identical kinetics. Figure 60(B) shows the second cycle $\mathrm{H}_{2}$ desorption curves of these two samples after recharging at $285^{\circ} \mathrm{C}$ and 190 bar $\mathrm{H}_{2}$ for 24 hours. The composite sample has slightly better kinetics than the SPEX milled one. Both samples released only about $2.9 \mathrm{wt} \% \mathrm{H}_{2}$, indicating incomplete rehydrogenation under these conditions. It can be concluded that incorporation of $\mathrm{Mg}\left(\mathrm{BH}_{4}\right)_{2}$ in $\mathrm{C}$ aerogel does not provide enhancement in kinetics and reversible capacity. 


\section{Hydride - Framework Composite Testing}

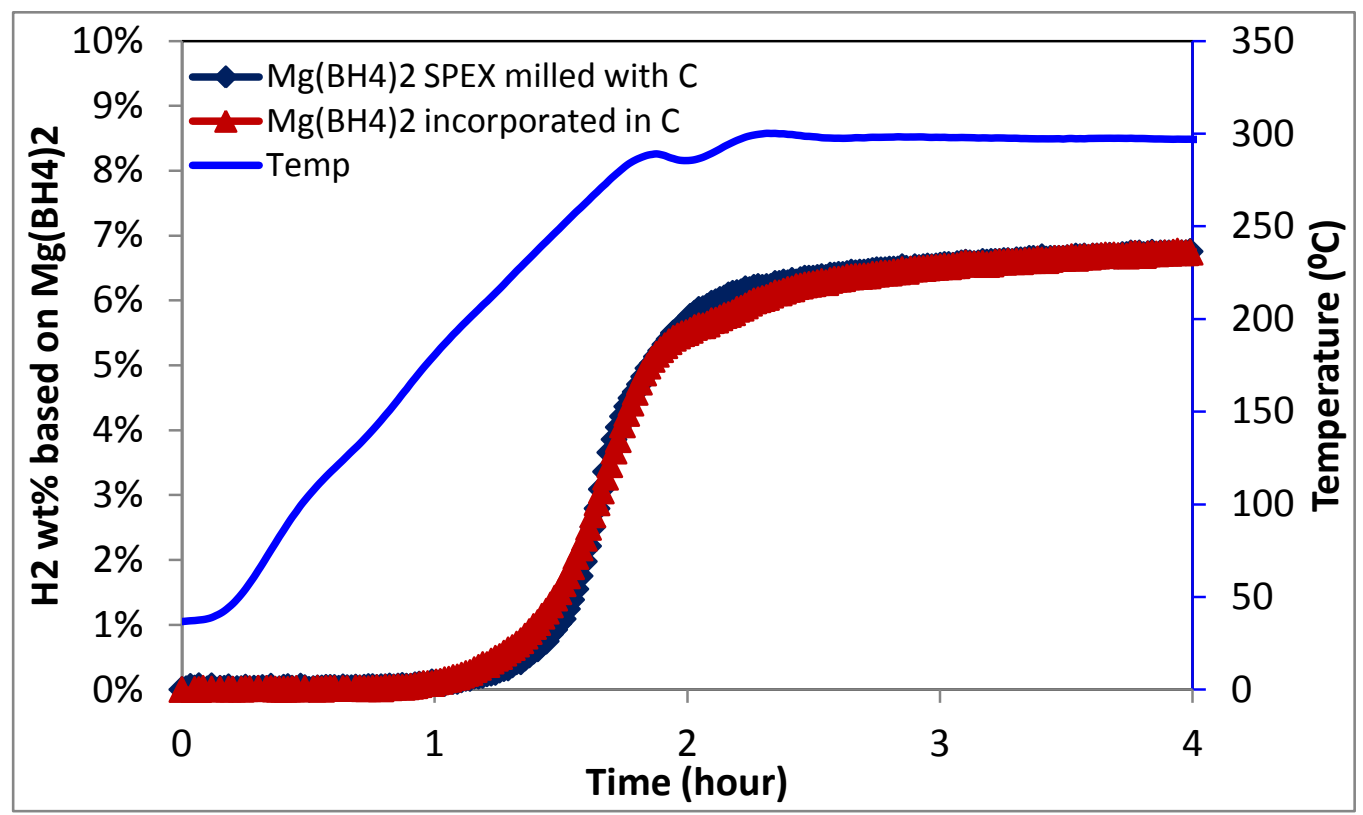

Figure 60: $\mathrm{H}_{2}$ desorption of $\mathrm{Mg}\left(\mathrm{BH}_{4}\right)_{2}$ incorporated in $\mathrm{C}(\mathrm{Red})$ and $\mathrm{Mg}\left(\mathrm{BH}_{4}\right)_{2}$ SPEX milled with $\mathrm{C}$ aerogel (Blue).

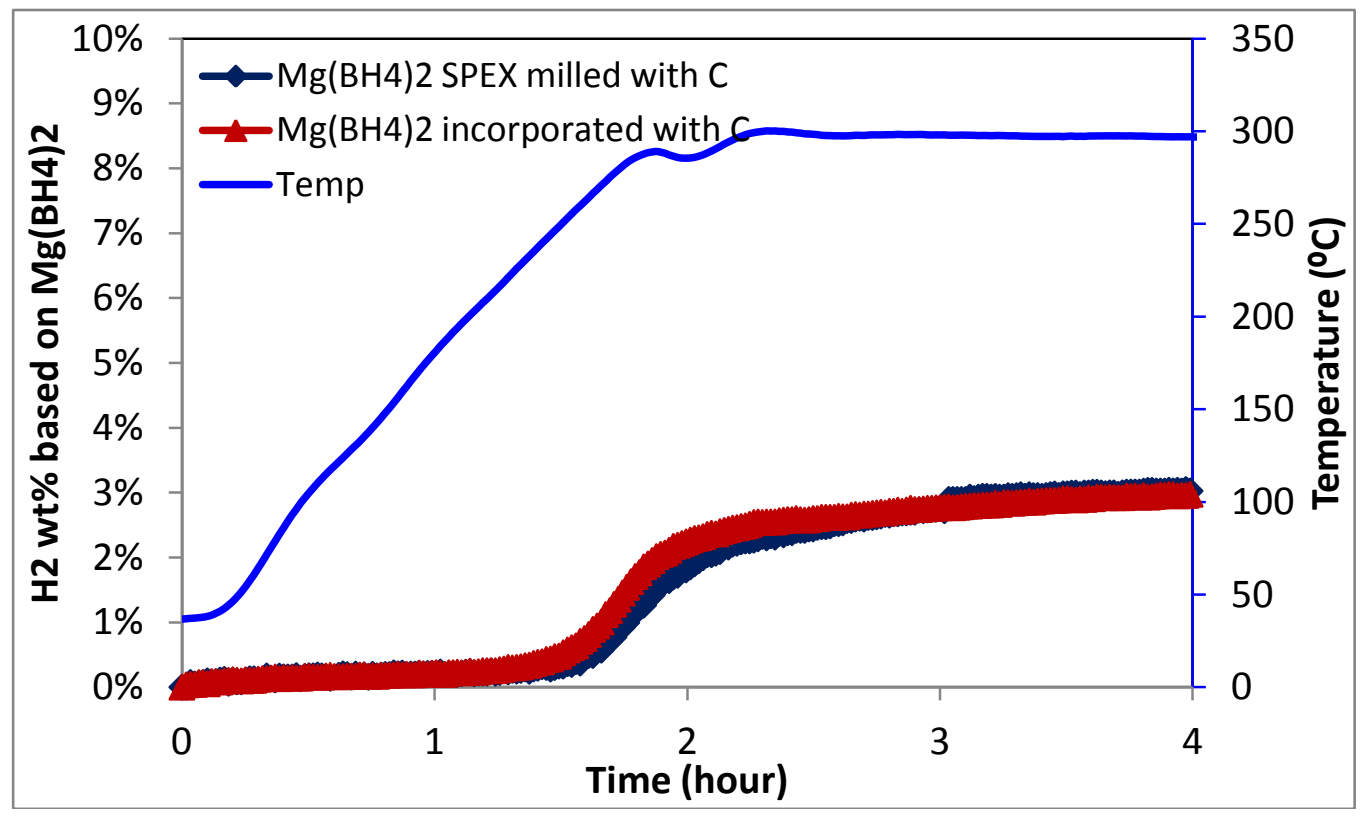

Figure 61: $2^{\text {nd }}$ cycle $\mathrm{H}_{2}$ desorption of $\mathrm{Mg}\left(\mathrm{BH}_{4}\right)_{2}$ incorporated in $\mathrm{C}$ and $\mathrm{Mg}\left(\mathrm{BH}_{4}\right)_{2}$ SPEX milled with $\mathrm{C}$ aerogel after rehydrogenation at $285^{\circ} \mathrm{C}$ and 190 bar of $\mathrm{H}_{2}$ pressure. 


\section{Hydride - Framework Composite Testing}

\subsection{Stabilization of $\mathrm{NaTi}\left(\mathrm{BH}_{4}\right)_{4} * \mathrm{DME}$ by Nano-Framework Materials}

Thermal stability of $\mathrm{NaTi}\left(\mathrm{BH}_{4}\right)_{4} * \mathrm{DME}$ incorporated into high surface area $\mathrm{SiO}_{2}$ was evaluated using DRIFTS spectrometry. Two different loadings of the active component were incorporated into the silica. A list of the loadings and species is given below:

- $40 \mathrm{wt} \% \mathrm{NaTi}\left(\mathrm{BH}_{4}\right)_{4} \cdot 3 \mathrm{DME}$ in $\mathrm{SiO}_{2}$

- $50 \mathrm{wt} \% \mathrm{NaTi}\left(\mathrm{BH}_{4}\right)_{4} \cdot 3 \mathrm{DME}$ in $\mathrm{SiO}_{2}$

- $\quad 25.8 \mathrm{wt} \% \mathrm{NaTi}\left(\mathrm{BH}_{4}\right)_{4} \cdot \mathrm{DME}$ in $\mathrm{SiO}_{2}$

- $33.5 \mathrm{wt} \% \mathrm{NaTi}\left(\mathrm{BH}_{4}\right)_{4} \cdot \mathrm{DME}$ in $\mathrm{SiO}_{2}$

The DRIFTS measurement results are shown in Figure 38. As can be seen from the figure, the absorbance areas for the C-H $\left(2700-3100 \mathrm{~cm}^{-1}\right)$ and $\mathrm{B}-\mathrm{H}\left(2000-2500 \mathrm{~cm}^{-1}\right)$ frequencies are consistent with the number of DME molecules (3DME vs 1DME ) in the complex, as well as the loading. The freshly prepared materials had bright blue color. They were allowed to age in ambient glove box conditions and the thermal decomposition was monitored by DRIFTS. The materials turned to gray and then black as they aged, indicating decomposition occurred over time. The DRIFTS measurements show that the B-H peaks $\left(2000-2500 \mathrm{~cm}^{-1}\right)$ decreased significantly in the materials that turned to black. The partially decomposed gray material still showed the same B-H peak intensity as the freshly made material. All materials showed at least partial decomposition at 14 days. The $\mathrm{NaTi}\left(\mathrm{BH}_{4}\right)_{4} * 3 \mathrm{DME}$ in $\mathrm{SiO}_{2}$ at $40 \mathrm{wt} \%$ loading was the most stable and showed only partial decomposition after 73 days. In this work, it was shown that inorganic nano-framework (silica) stabilized $\mathrm{NaTi}\left(\mathrm{BH}_{4}\right)_{4}$. However, this material still decomposed over time at ambient temperature, and is not stable enough for practical application. 


\section{Hydride - Framework Composite Testing}

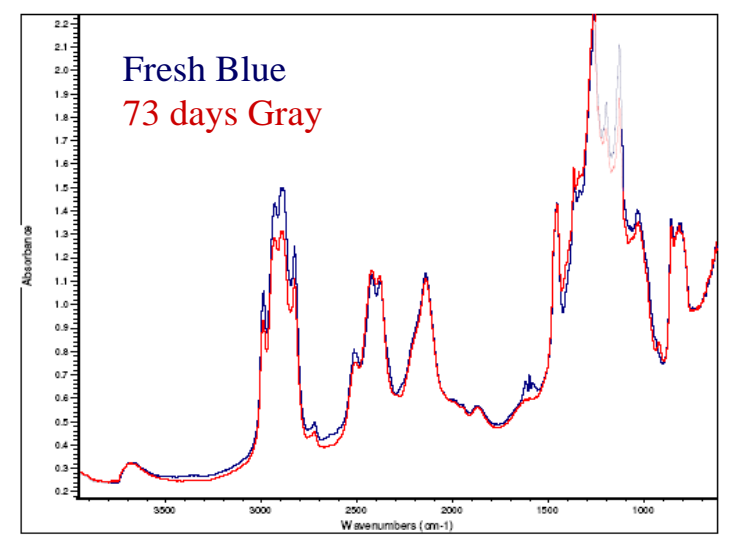

$40 \mathrm{wt} \% \mathrm{NaTi}\left(\mathrm{BH}_{4}\right)_{4} \cdot 3 \mathrm{DME}$ in $\mathrm{SiO}_{2}$

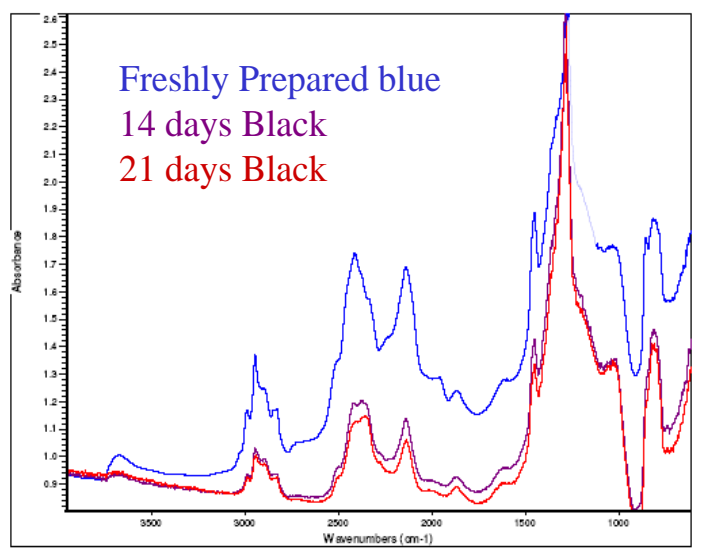

$25.8 \mathrm{wt} \% \mathrm{NaTi}\left(\mathrm{BH}_{4}\right)_{4} \cdot \mathrm{DME}$ in $\mathrm{SiO}_{2}$

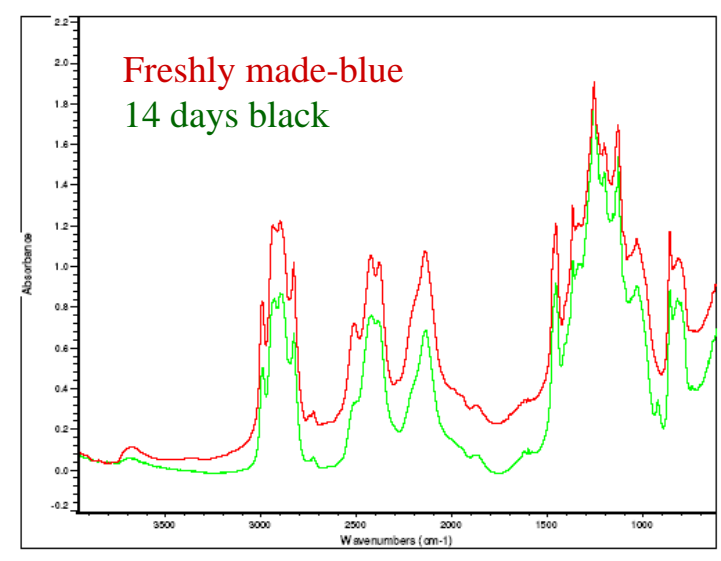

$50 \mathrm{wt} \% \mathrm{NaTi}\left(\mathrm{BH}_{4}\right)_{4} \cdot 3 \mathrm{DME}$ in $\mathrm{SiO}_{2}$

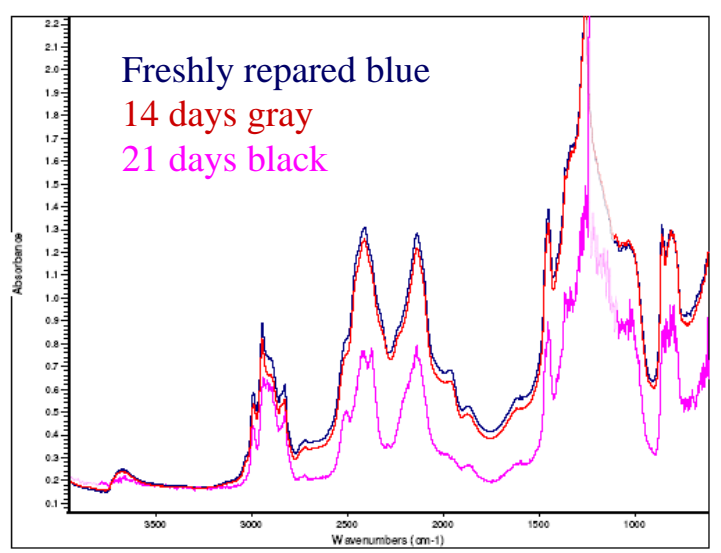

$33.5 \mathrm{wt} \% \mathrm{NaTi}\left(\mathrm{BH}_{4}\right)_{4} \cdot \mathrm{DME}$ in $\mathrm{SiO}_{2}$

Figure 62: DRIFTS spectra of $\mathrm{NaTi}\left(\mathrm{BH}_{4}\right)_{4} \cdot 3 \mathrm{DME}$ and $\mathrm{NaTi}\left(\mathrm{BH}_{4}\right)_{4} \cdot \mathrm{DME}$ supported on silica. 


\section{Carbon Aerogel-Hydride Nano-Framework Thermal Conductivity and Permeability Estimation \\ 8 Carbon Aerogel - Hydride Composite Thermal Conductivity and Permeability Estimation}

Due to limited knowledge of internal structure of the aerogel material, transport properties such as effective thermal conductivity and permeability can be estimated approximately using simplified general assumptions. The thermal conductivity of $\mathrm{NaAlH}_{4}$ was used here since similar data from $\mathrm{Ca}\left(\mathrm{BH}_{4}\right)_{2}$ is not available.

\subsection{Effective Thermal Conductivity (ETC)}

ETC in absence of detail information can be estimated based on the rule of mixtures [27].

$\mathrm{ETC}=\mathrm{k}$ aerogel $*(1-\varepsilon)+\mathrm{k}$ hydride $* \varepsilon=0.29 \mathrm{~W} / \mathrm{m} / \mathrm{K}$

$\mathrm{k}$ aerogel - thermal conductivity of aerogel, $0.035 \mathrm{~W} / \mathrm{m} / \mathrm{K}$

$\mathrm{k}$ hydride - thermal conductivity of hydride, $0.55 \mathrm{~W} / \mathrm{m} / \mathrm{K}$

W: watt

m: meter

K: Kelvin

\subsection{Permeability $K$}

Assuming that permeability of combined aerogel-hydride material can be estimated by representing it as an equivalent packed bed of spheres with equivalent diameter calculated form surface to volume ratio [28]:

$K=\frac{D p^{2} \varepsilon^{3}}{A(1-\varepsilon)}=1.82 * 10^{-9} \mathrm{~m}^{2}$

$\varepsilon-$ porosity

$A=147$ for packed bed of spheres

$\mathrm{Dp}-$ equivalent sphere diameter $=\frac{6(1-\varepsilon)}{\beta}$

$\beta$ - surface area to volume ratio 


\section{Carbon Aerogel-Hydride Nano-Framework Thermal Conductivity and Permeability Estimation}

Table 17: Estimation of thermal conductivity and $\mathrm{H}_{2}$ permeability in $\mathrm{C}$ aerogel

\begin{tabular}{|l|r|}
\hline Carbon Aerogel - PF2 (Phenolic Pyrolysis 08020064) & \\
\hline & \\
\hline Density, $\rho$ & $200 \mathrm{~kg} / \mathrm{m} 3$ \\
\hline Void fraction (porosity), $\varepsilon$ & 0.5 \\
\hline Thermal conductivity, k aerogel & $0.035 \mathrm{~W} / \mathrm{m} / \mathrm{K}$ \\
\hline Surface area & $818400 \mathrm{~m} 2 / \mathrm{kg}$ \\
\hline Surface area to volume, $\beta$ & $4092 \mathrm{~m} 2 / \mathrm{m} 3$ \\
\hline Equivalent sphere diameter, Dp & $0.00073314 \mathrm{~m}$ \\
\hline A-factor for packed spheres & $147[2]$ \\
\hline
\end{tabular}

\begin{tabular}{|l|r|}
\hline NaAlH4 Hydride & 0.5 \\
\hline Volumetric fraction & $0.55 \mathrm{~W} / \mathrm{m} / \mathrm{K}$ \\
\hline Thermal conductivity, k hydride & \\
\hline
\end{tabular}

Equivalent thermal conductivity (ETC) [1]

Permeability K for packed bed of spheres [2]

$0.2925 \mathrm{~W} / \mathrm{m} / \mathrm{K}$

$1.8282 \mathrm{E}-09 \mathrm{~m} 2$ 


\section{Conclusions}

\section{Conclusions and Recommendations}

This project demonstrated combined atomic and thermodynamic modeling with experimental synthesis, characterization and performance testing to progressively investigate the interactions and mechanistic behavior of advanced hydrogen storage nano-framework systems of increasing complexity, including nano-framework functionalization with surface functional groups, hydrogen activation catalysts or surface-active ligands.

Atomic modeling simulations surveyed interfacial interactions of the most stable surfaces of oxide nano-framework candidates: $\mathrm{Al}_{2} \mathrm{O}_{3}, \mathrm{ZrO}_{2}$, and $\mathrm{SiO}_{2}$ with lithium borohydride, $\mathrm{LiBH}_{4} . \mathrm{ZrO}_{2}(101)$ surface was identified as the oxide surface least likely to interact with the hydride and form undesirable side products. This prediction was subsequently verified by experimental reactivity testing. Atomic simulations of the hydride candidate, calcium borohydride, $\mathrm{Ca}\left(\mathrm{BH}_{4}\right)$, revealed that the dehydrogenation enthalpies were slightly increased by the presence of the $\mathrm{ZrO}_{2}$ surface, rendering $\mathrm{Ca}\left(\mathrm{BH}_{4}\right)_{2}$ less thermodynamically reversible. Further mechanistic investigations demonstrated the utility of $\mathrm{H}_{2}$ activation catalysts, such as $\mathrm{Pt}$, can facilitate formation, adsorption, and transfer of atomic $\mathrm{H}$, and enhance binding and rehydrogenation of dehydrided phases. Atomic simulations explored stabilization of unstable, high capacity hydrogen storage media, $\mathrm{NaTi}\left(\mathrm{BH}_{4}\right)_{4}$, using surface functionalized inorganic nano-frameworks. Ethylenediamine (EDA) was identified as the best candidate among several amine functionalizing agents that can slightly thermodynamically stabilize this unstable hydride in the presence of the $\mathrm{ZrO}_{2}$ surface.

Several high surface area metal oxides $\left(\mathrm{SiO}_{2}, \mathrm{Al}_{2} \mathrm{O}_{3}\right.$ and yittria stabilized zirconia (YSZ)) and $\mathrm{C}$ (polyimide (PI) and phenolic polymer (PF) derived) nano framework materials were developed and tested as possible nano-framework materials. YSZ and phenolic polymer (PI) derived $\mathrm{C}$ aerogel materials were identified as most stable nano-framework materials against borohydrides. C (both PI and $\mathrm{PF}$ ) aerogels and Pt/YSZ showed enhancement in $\mathrm{H}_{2}$ desorption kinetics in SPEX milled mixtures with $\mathrm{Ca}\left(\mathrm{BH}_{4}\right)_{2}$.

Three borohydrides, $\mathrm{Ca}\left(\mathrm{BH}_{4}\right)_{2}, \mathrm{Mg}\left(\mathrm{BH}_{4}\right)_{2}$ and $\mathrm{NaTi}\left(\mathrm{BH}_{4}\right)_{4}$ were successfully incorporated in nanoframework matrix. High hydride loading was achieved with $\mathrm{C}$ aerogel using solution infiltration method. The particle sizes of the hydride formed inside the $\mathrm{C}$ nano-framework is estimated as $<25$ nm. The hydride - nano-framework composites were cycled in Sievert's apparatus to measure $\mathrm{H}_{2}$ desorption kinetics and absorption capacity. Improvements in $\mathrm{H}_{2}$ desorption kinetics were observed in hydride - framework composites for all stable hydrides $\left(\mathrm{Ca}\left(\mathrm{BH}_{4}\right)_{2} \text { and } \mathrm{Mg}\left(\mathrm{BH}_{4}\right)_{2}\right)^{2} \mathrm{Ca}\left(\mathrm{BH}_{4}\right)_{2}-\mathrm{C}$ (both PI and PF) composites showed most significant kinetics enhancement and significant decrease in desorption temperature. No improvements in $\mathrm{H}_{2}$ absorption capacity were detected in these composites due to the formation of stable intermediate, alkaline earth $\mathrm{B}_{12} \mathrm{H}_{12}$. This stable intermediate hinders complete rehydrogenation of $\mathrm{Ca}\left(\mathrm{BH}_{4}\right)_{2}$ and $\mathrm{Mg}\left(\mathrm{BH}_{4}\right)_{2}$, therefore reduced their reversibility. The stability of unstable $\mathrm{NaTi}\left(\mathrm{BH}_{4}\right)_{4}$ was improved significantly through incorporation into $\mathrm{SiO}_{2}$ aerogel, indicating stabilization effect of nano framework through surface interactions.

This project demonstrated that nano-framework confinement provides a unique approach to improve hydride properties by significant decreasing desorption temperature and enhancement of kinetics for highly stable hydrides, stabilization of unstable hydrides through surface functionalization and maintenance of nano-scale phases domain during cycling. However, the inability of current aerogels to circumvent the formation of stable alkaline earth $\mathrm{B}_{12} \mathrm{H}_{12}$ intermediates was the main cause for 


\section{Conclusions}

reduced absorption capacity of the borohydrides investigated. Nonetheless, this unique approach can be applied in reversible hydride systems where improvements in kinetics and cyclability are needed. Further development in intrinsically functionalized carbon with engineered pore structure can be utilized to stabilize unstable high capacity borohydrides and improve cyclability. 


\section{Publications and Presentations}

\section{Publications and Presentations}

\subsection{Publication}

1. S. M. Opalka, X. Tang, B. L. Laube, and T. H .Vanderspurt, "Experimental and theoretical screening of nanoscale oxide reactivity with $\mathrm{LiBH}_{4}$," Nanotechnology 20(20) (2009) 204024.

\subsection{Presentations}

1. X. Tang, S. M. Opalka, D. A. Mosher, T. H. Vanderspurt, B. L. Laube, and R. Brown, "Catalyzed Nano-Framework Stabilized High Density Reversible Hydrogen Storage Systems," IEA Task 22, Paris, France, Oct 12-15, 2009.

2. S. M. Opalka, T. H. Vanderspurt, and X. Tang, "Complex borohydride and hydrogen interactions with Pt-loaded $\mathrm{ZrO}_{2}$ frameworks," invited, Workshop on Atomistic Interfaces '09: Ionic Solids, University of Connecticut, Storrs, CT, August 24-26, 2009.

3. X. Tang, S. M. Opalka, D. A. Mosher, T. H. Vanderspurt, B. L. Laube, and R. Brown, "Catalyzed Nano-Framework Stabilized High Density Reversible $\mathrm{H}_{2}$ Storage Systems," IEA Task 22 Meeting, Jeju, South Korea, April 20-23, 2009.

4. S. M. Opalka, X. Tang, T. H. Vanderspurt, D. A. Mosher, and B. L. Laube, "Complex borohydride and $\mathrm{H}_{2}$ interactions with Pt-loaded $\mathrm{ZrO}_{2}$ frameworks," $237^{\text {th }}$ ACS National Meeting, Salt Lake City, March 22-26, 2009.

5. X. Tang, S. M. Opalka, D. A. Mosher, T. H. Vanderspurt, B. L. Laube, R. J. Brown, E Rönnebro, T. J. Boyle, L. Ottley, M Ong, F-J Wu, and J Strickler, "Catalyzed NanoFrameworks", Storage Tech Team Meeting, Southfield, MI, February 19, 2009.

6. D A Mosher, S M Opalka, X Tang, S Arsenault, T H Vanderspurt, B L Laube, R J Brown, "Catalyzed Nano-Framework Stabilized High Density Reversible Hydrogen Storage Systems," IEA Task 22 Meeting, Rome, Italy, October 6-10, 2008.

7. D A Mosher, S. Arsenault, S M Opalka, T H Vanderspurt, X Tang, B L Laube, E Ronnebro and T J Boyle, "Development of nano-framework / hydride composites for improved hydrogen storage," poster Int. Symposium on Metal-Hydrogen Systems (MH2008), Reykjavík, Iceland, June 24-28, 2008.

8. D. Mosher, S. Arsenault, S. Opalka, X. Tang, T. Vanderspurt, B. Laube and R. Brown, "Catalyzed Nano-Framework Stabilized High Density Reversible Hydrogen Storage Systems," IEA Task 22 Meeting, Quebec, Canada, March 2-5, 2008.

9. D. Mosher, S. Opalka, X. Tang, S. Arsenault, T. Vanderspurt, B. Laube and R. Brown, "Development and Application of New High Capacity Hydrogen Storage Materials," IEA Task 22 Meeting, Petten, Netherlands, September 3-7, 2007. 


\section{Appendices}

\section{References}

1. Targets for On-Board Hydrogen Storage Systems: Current R\&D Focus is on 2010 Targets, Available from:

http://www1.eere.energy.gov/hydrogenandfuelcells/storage/current_technology.html.

2. Kresse G and Hafner J 1993 Ab initio molecular dynamics for liquid metals Phys. Rev. B 47 558-61.

3. Kresse $\mathrm{G}$ and Furthmuller J 1996 Efficiency of ab-initio total energy calculations for metals and semiconductors using a plane-wave basis set Comput. Mater. Sci. 6 15-50.

4. Kresse $\mathrm{G}$ and Furthmuller J 1996 Efficient iterative schemes for ab initio total energy calculations using a plane wave basis set Phys. Rev. B 54 11169-86.

5. Kresse G and Joubert D 1999 From ultrasoft pseudopotentials to the projector augmented wave method Phys. Rev. B 59 1758-75.

6. Perdew J and Wang Y 1992 Generalized gradient approximation for the exchange-correlation hole of a many-electron system Phys. Rev. B 46 6671-87.

7. Fujimori H, Yashima M, Kakihana M and Yoshimura M 1998 Structural changes of scandiadoped zirconia solid solutions: Rietveld analysis and Raman scattering J. Am. Ceram. Soc. 81 2885-93

8. Pillet S, Souhassou M, Lecomte C, Schwarz K, Blaha P, Rerat M, Lichanot A and Roversi P 2001 Recovering experimental and theoretical electron densities in corundum using the multipolar model: IUCr multipole refinement project Acta Crystallogr. A 57 290-303

9. Glinnemann J, King H E, Schulz H, Hahn T, la Placa S J and Dacol F 1992 Crystal structures of the low-temperature quartz-type phases of $\mathrm{SiO} 2$ and $\mathrm{GeO} 2$ at elevated pressure $Z$. Kristallogr. 198 177-212

10. Cerny R, Yvon K, Soulie J-P and Renaudin G 2002 Lithium boro-hydride LiBH4 J. Alloys Compounds 346 200-5

11. Züttel, P. Wenger, S. Rentsch, P. Sudan, Ph. Mauron, and Ch. Emmenegger $2003 \mathrm{LiBH}_{4}$ a new hydrogen storage material J. Power Sources 118 1-7

12. Satyapal S, Petrovic J, Read C, Thomas G and Ordaz G 2007 The U.S. Department of Energy's National Hydrogen Storage Project: Progress towards meeting hydrogen-powered vehicle requirements Catal. Today 120 246-56

13. Opalka S M, Løvvik O M, Brinks H W, Saxe P W and Hauback BC 2007 Integrated experimental-theoretical investigation of the $\mathrm{Na}-\mathrm{Li}-\mathrm{Al}-\mathrm{H}$ system Inorg. Chem. 46 1401-9

14. 1985 JANAF Thermochemical Tables, 3rd ed., eds. Chase MW et al. J. of Phys. Chem. Ref. Data 14 Suppl 1 1-1856

15. Y. Filinchuk, E. Rönnebro, and D. Chandra, "Crystal structures and phase transformations in $\mathrm{Ca}\left(\mathrm{BH}_{4}\right)_{2}, "$ Acta Mater. 572009 732-738.

16. V. Ozolins, E. H. Majzoub, and C. J. Wolverton, "First-principles prediction of thermodynamically reversible hydrogen storage," Am. Chem. Soc., 131 (2009) 230-237.

17. Lin-Lin Wang, Dennis D.Graham, Ian M. Robertson and Duane D. Johnson, "On the reversibility of hydrogen-storage reactions in $\mathrm{Ca}(\mathrm{BH} 4) 2$ : Characterization via experiment and theory," J. Phys. Chem. C, 2009, 113 (46), pp 20088-20096.

18. L. Chen, G. Pez, A. C. Cooper, and H. Cheng, "A mechanistic study of hydrogen spillover in MoO3 and carbon-based graphitic materials," J. Phys. Condens. Matter 20 (2008) 064223-1-7.

19. J. Graetz, S. Chaudhuri, J. Wegrzyn, Y. Celebi, J. R. Johnson, W. Zhou, and J. J. Reilly, "Direct and Reversible Synthesis of $\mathrm{AlH}_{3}-$ Triethylenediamine from $\mathrm{Al}$ and $\mathrm{H}_{2}$, , J. Phys. Chem. C, 2007, 111 (51), 19148-19152. 


\section{Appendices}

20. G. Henkelman, A. Arnaldsson, and H. Jónsson, “A fast and robust algorithm for Bader decomposition of charge density," Comput. Mater. Sci. 36 (2006) 254-360.

21. Outokumpu HSC Chemistry for Windows, version 5.1, 2002.

22. Vanderspurt T H, Wijzen F, Tang X, Leffler M P, Willigan R R, Newman C A, Radhakrishnan R, Feng F, Laube B L, Dardas Z, Opalka S M and She Y 2007 Ceria-based mixed-metal oxide structure, including method of making and use US Patent Specification 7166263.

23. Vajo J J and Olson G L 2007 Hydrogen storage in destabilized chemical systems Scr. Mater. 56 829-34;

24. Gross A F, Vajo J J, Van Atta S L and Olson G L 2008 Enhanced hydrogen storage kinetics of LiBH4 in nanoporous carbon scaffolds J. Phys. Chem. C 112 5651-57.

25. Ming A 2006 Destabilized and catalyzed borohydrides for reversible hydrogen storage $U S$ Patent Application 2006194695.

Ming A, Spencer W, Jurgensen A and Zeigler C 2008 Hydrogen storage properties of modified lithium borohydrides J. Alloy. Compd. 462 303-309.

26. Lennie Klebanoff, Jay Keller, Development of Metal Hydrides at Sandia National Laboratories, 2009. http://www.hydrogen.energy.gov/pdfs/progress09/iv_a_1c_klebanoff.pdf.

27. D.P.H. Hasselman, et al, "Effective Thermal Conductivity of Uniaxial Composites with Cylindrically Orthotropic Carbon Fibers and Interfacial Thermal Barrier” Journal of Composite Materials, 276 (1993) pp. 637 - 644.

28. Yu, QJ, A unit cube-based model for heat transfer and fluid flow in porous carbon foam, Transactions of the ASME. Journal of heat transfer, 128/4:352-360 4/2006. 


\section{Appendices}

\section{Appendices}

Table 18: HSC equilibrium thermodynamic calculations of equations (7-9).

\begin{tabular}{|c|c|c|c|}
\hline $\begin{array}{c}\mathrm{T} \\
\left({ }^{\circ} \mathrm{C}\right)\end{array}$ & $\begin{array}{l}\Delta H \\
(\mathrm{~kJ})\end{array}$ & $\begin{array}{c}\Delta S \\
(\mathrm{~J} / \mathrm{K})\end{array}$ & $\begin{array}{l}\Delta G \\
(\mathrm{~kJ})\end{array}$ \\
\hline 100 & 344.136 & -129.311 & 392.388 \\
\hline 150 & 347.367 & -121.186 & 398.647 \\
\hline 200 & 350.737 & -113.662 & 404.517 \\
\hline 250 & 354.471 & -106.169 & 410.014 \\
\hline 300 & 359.011 & -97.897 & 415.120 \\
\hline \multicolumn{4}{|c|}{ 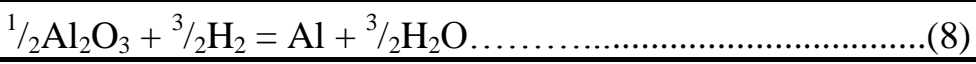 } \\
\hline $\begin{array}{c}\mathrm{T} \\
\left({ }^{\circ} \mathrm{C}\right)\end{array}$ & $\begin{array}{c}\Delta H \\
(\mathrm{~kJ})\end{array}$ & $\begin{array}{c}\Delta S \\
(\mathrm{~J} / \mathrm{K})\end{array}$ & $\begin{array}{l}\Delta G \\
(\mathrm{~kJ})\end{array}$ \\
\hline 100 & 413.076 & -76.385 & 441.579 \\
\hline 150 & 415.619 & -69.988 & 445.235 \\
\hline 200 & 418.217 & -64.188 & 448.588 \\
\hline 250 & 421.054 & -58.495 & 451.655 \\
\hline 300 & 424.482 & -52.248 & 454.428 \\
\hline \multicolumn{4}{|c|}{$\mathrm{ZrO}_{2}+2 \mathrm{H}_{2}=\mathrm{Zr}+2 \mathrm{H}_{2} \mathrm{O} \ldots \ldots \ldots \ldots \ldots \ldots \ldots \ldots \ldots \ldots \ldots \ldots \ldots \ldots \ldots \ldots \ldots \ldots \ldots \ldots$} \\
\hline $\begin{array}{c}\mathrm{T} \\
\left({ }^{\circ} \mathrm{C}\right) \\
\end{array}$ & $\begin{array}{c}\Delta H \\
(\mathrm{~kJ}) \\
\end{array}$ & $\begin{array}{c}\Delta S \\
(\mathrm{~J} / \mathrm{K})\end{array}$ & $\begin{array}{l}\Delta G \\
(\mathrm{~kJ})\end{array}$ \\
\hline 100 & 533.180 & -119.070 & 577.611 \\
\hline 150 & 536.170 & -111.553 & 583.374 \\
\hline 200 & 539.334 & -104.490 & 588.774 \\
\hline 250 & 542.909 & -97.318 & 593.821 \\
\hline 300 & 547.346 & -89.235 & 598.490 \\
\hline
\end{tabular}




\section{Appendices}

Table 19: HSC equilibrium thermodynamic calculations of equations (10-13).

\begin{tabular}{|c|c|c|c|}
\hline $\begin{array}{c}\mathrm{T} \\
\left({ }^{\circ} \mathrm{C}\right)\end{array}$ & $\begin{array}{l}\Delta H \\
(\mathrm{~kJ})\end{array}$ & $\begin{array}{c}\Delta S \\
(\mathrm{~J} / \mathrm{K})\end{array}$ & $\begin{array}{l}\Delta G \\
(\mathrm{~kJ})\end{array}$ \\
\hline 100 & 82.549 & 216.003 & 1.948 \\
\hline 150 & 82.735 & 216.471 & -8.864 \\
\hline 200 & 82.860 & 216.751 & -19.696 \\
\hline 250 & 82.901 & 216.836 & -30.536 \\
\hline 300 & 82.867 & 216.773 & -41.377 \\
\hline \multicolumn{4}{|c|}{$4 \mathrm{LiBH}_{4}+3 \mathrm{SiO}_{2}=2 \mathrm{Li}_{2} \mathrm{SiO}_{3}+\mathrm{SiB}_{4}+8 \mathrm{H}_{2} \ldots \ldots \ldots \ldots \ldots \ldots \ldots \ldots \ldots \ldots \ldots \ldots \ldots \ldots \ldots \ldots \ldots \ldots$} \\
\hline $\begin{array}{c}\mathrm{T} \\
\left({ }^{\circ} \mathrm{C}\right)\end{array}$ & $\begin{array}{c}\Delta H \\
(\mathrm{~kJ}) \\
\end{array}$ & $\begin{array}{c}\Delta S \\
(\mathrm{~J} / \mathrm{K})\end{array}$ & $\begin{array}{l}\Delta G \\
(\mathrm{~kJ})\end{array}$ \\
\hline 100 & 130.023 & 822.379 & -176.847 \\
\hline 150 & 130.643 & 823.941 & -218.007 \\
\hline 200 & 130.898 & 824.519 & -259.224 \\
\hline 250 & 130.642 & 824.013 & -300.441 \\
\hline 300 & 129.871 & 822.613 & -341.610 \\
\hline \multicolumn{4}{|c|}{$3 \mathrm{LiBH}_{4}+2 \mathrm{Al}_{2} \mathrm{O}_{3}=3 \mathrm{LiAlO}_{2}+\mathrm{AlB}_{2}+\mathrm{B}+6 \mathrm{H}_{2} \ldots \ldots \ldots \ldots \ldots \ldots . .(12)$} \\
\hline $\begin{array}{c}\mathrm{T} \\
\left({ }^{\circ} \mathrm{C}\right)\end{array}$ & $\begin{array}{c}\Delta H \\
(\mathrm{~kJ}) \\
\end{array}$ & $\begin{array}{c}\Delta S \\
(\mathrm{~J} / \mathrm{K})\end{array}$ & $\begin{array}{l}\Delta G \\
(\mathrm{~kJ})\end{array}$ \\
\hline 100 & 207.523 & 660.605 & -38.982 \\
\hline 150 & 208.662 & 663.467 & -72.084 \\
\hline 200 & 209.624 & 665.623 & -105.315 \\
\hline 250 & 210.209 & 666.805 & -138.630 \\
\hline 300 & 210.321 & 667.018 & -171.980 \\
\hline \multicolumn{4}{|c|}{$5 \mathrm{LiBH}_{4}+2 \mathrm{ZrO}_{2}=\mathrm{LiBO}_{2}+2 \mathrm{Li}_{2} \mathrm{O}+2 \mathrm{ZrB}_{2}+10 \mathrm{H}_{2} \ldots \ldots \ldots \ldots \ldots . \ldots \ldots$} \\
\hline $\begin{array}{c}\mathrm{T} \\
\left({ }^{\circ} \mathrm{C}\right) \\
\end{array}$ & $\begin{array}{c}\Delta H \\
(\mathrm{~kJ}) \\
\end{array}$ & $\begin{array}{c}\Delta S \\
(\mathrm{~J} / \mathrm{K}) \\
\end{array}$ & $\begin{array}{r}\Delta G \\
(\mathrm{~kJ}) \\
\end{array}$ \\
\hline 100 & 294.052 & 1029.665 & -90.168 \\
\hline 150 & 294.836 & 1031.633 & -141.699 \\
\hline 200 & 295.472 & 1033.059 & -193.320 \\
\hline 250 & 295.729 & 1033.583 & -244.990 \\
\hline 300 & 295.548 & 1033.260 & -296.664 \\
\hline
\end{tabular}

